Sara María Costa Garay

\title{
A participação brasileira no desenvolvimento do agronegócio no Paraguai: uma análise crítica
}

Dissertação de Mestrado

Dissertação apresentada como requisito parcial para obtenção do título de Mestre pelo Programa de Pós-graduação em Relações Internacionais do Instituto de Relações Internacionais da PUC-Rio.

Orientador: Prof. José María Gómez

Rio de Janeiro

Agosto de 2014 


\section{A participação brasileira no desenvolvimento do agronegócio no Paraguai: uma análise crítica}

Dissertação apresentada como requisito parcial para obtenção do título de Mestre pelo Programa de Pós-graduação em Relações Internacionais do Instituto de Relações Internacionais da PUC-Rio. Aprovada pela Comissão Examinadora abaixo assinada.

Prof. José María Gómez

Orientador e Presidente Instituto de Relações Internacionais - PUC-Rio

Profa. Ana Elisa Saggioro Garcia Muller Universidade Federal Rural do Rio de Janeiro - UFRRJ

Prof. Mathias Seibel Luce Universidade Federal do Rio Grande do Sul - UFRGS

Profa. Mônica Herz

Vice-Decana de Pós-Graduação do Centro de Ciências Sociais - PUC-Rio

Rio de Janeiro, 18 de Agosto de 2014 
Todos os direitos reservados. É proibida a reprodução total ou parcial do trabalho sem a autorização da universidade, da autora e do orientador.

\section{Sara María Costa Garay}

Graduou-se em Administração de Empresas (com habilitação em Recursos Humanos) na Faculdade de Administração e Ciências Contábeis da Universidade Federal do Rio de Janeiro (FACC/UFRJ) em 2011. Faz parte do corpo editorial da Revista Cadernos de Relações Internacionais da Pontifícia Universidade Católica do Rio de Janeiro (PUC-Rio).

Ficha Catalográfica

\section{Garay, Sara María Costa}

A participação brasileira no desenvolvimento do agronegócio no Paraguai: uma análise crítica / Sara María Costa Garay ; orientador: José María Gómez. - 2014.

205 f. : il. (color.) ; $30 \mathrm{~cm}$

Dissertação

(mestrado)-Pontifícia

Universidade Católica do Rio de Janeiro, Instituto de Relações Internacionais, 2014.

Inclui bibliografia

1. Relações internacionais - Teses. 2. Agronegócio. 3. Paraguai. 4. Brasil. 5. Economia capitalista mundial. 6. Desenvolvimento desigual. 7. Dependência. 8. Subimperialismo. I. Gómez, José María. II. Pontifícia Universidade Católica do Rio de Janeiro. Instituto de Relações Internacionais. III. Título. 


\section{Agradecimentos}

Este trabalho não teria sido possível sem a ajuda e o alento constante de diversas pessoas.

Em primeiro lugar, gostaria de agradecer aos professores que, além de contribuir diretamente para a elaboração deste trabalho, se tornaram essenciais para a minha formação acadêmica e pessoal ao longo deste mestrado. Ao professor, e orientador da pesquisa, José María Gómez, pela confiança depositada em mim e pela inspiração proporcionada nas aulas e nas conversas fora de sala. E à professora Ana Saggioro Garcia, pela disposição e dedicação de sempre, e por me ajudar a destravar minhas ideias. Obrigado a ambos por terem me guiado nesta empreitada, e por despertar e incentivar meu espírito crítico.

Aos demais professores e professoras de quem tive o prazer de ser aluna na minha passagem pelo IRI, e que proporcionaram aulas e lições inesquecíveis: o prof. Pedro Cunca Bocayuva (a quem também agradeço pelos seus comentários sobre o projeto da pesquisa); prof. Luis M. Fernandes; prof ${ }^{a}$. Marta Moreno; prof ${ }^{a}$. Carolina Moulin; prof ${ }^{a}$. Adriana Abdenur; prof. João P. Nogueira; prof. Kai M. Kenkel, e prof. Fabiano Mielniczuk.

Às professoras Luciana Badin e Leane C. Naidin, por terem me ajudado a dar meus primeiros passos na docência. Igualmente, ao professor e amigo Miguel Borba, por tê-lo feito de forma voluntária, e também pelas dicas para os estudos sobre América Latina.

Ao professor Mathias Seibel Luce da UFRGS, por aceitar meu convite para debater sobre o tema de meu trabalho, participando da banca examinadora, e com quem aprendi muito, apesar de não ter sido sua aluna.

A todos os funcionários do IRI, pelo apoio "logístico" ao longo desses dois anos. Especialmente, a Lia González, pela disposição e ajuda de sempre. 
A minha turma de mestrado que, com certeza, é uma das melhores turmas com que tive a chance de conviver, e tornou-se um fator essencial para fazer desta transição de profissão que decidi encarar, um processo menos sofrido. Em especial, aos que se tornaram meus grandes confidentes ao longo deste processo: Kárida, Mariana, Jéssica M., Thauan, Tina e Vanessa.

Ao Instituto de Relações Internacionais (IRI) de uma forma geral, pelas oportunidades de aprendizado nesses dois anos.

Aos pesquisadores e intelectuais que me receberam no Paraguai, no contexto da realização desta pesquisa, e se disponibilizaram para debater sobre o tema, contribuindo de forma fundamental para o desenvolvimento do trabalho e das minhas reflexões: Luis Rojas, e demais membros da equipe de BASE IS; Cecília Vuyk (C\&P); Daniel Campos (SER); Ramón Fogel (CERI); e Luis A. Galeano (CPES). Também ao Gustavo Codas, por me ajudar nos primeiros passos da pesquisa. Ao Centro de Documentación y Estudios (CDE) e ao Comité de Iglesias para Ayudas de Emergencias (CIPAE), por me deixarem vasculhar em suas bibliotecas.

A minha família, que preza por mim de todas as formas possíveis. Principalmente, aos meus pais, pelo apoio emocional e financeiro.

Aos amigos/as de sempre do Rio de Janeiro: obrigado pela paciência e por compreender meu sumiço! Às minhas meninas: Natália, Patrícia, Raissa e Tatiana. E ao Paul, por ter se tornado meu porto seguro.

Aos amigos/as no Paraguai, que continuam firmes apesar do tempo e da distância, me nutrindo com seu imenso carinho. Em especial a Betânia e Silvana.

Finalmente, gostaria de agradecer ao Conselho Nacional de Desenvolvimento Científico e Tecnológico (CNPQ); à Fundação de Amparo à Pesquisa do Estado do Rio de Janeiro (FAPERJ) e à Pontifícia Universidade Católica do Rio de Janeiro (PUC-Rio), pelos auxílios concedidos, que me permitiram realizar este mestrado. 


\section{Resumo}

Garay, Sara María Costa; Gómez, José Maria. A participação brasileira no desenvolvimento do agronegócio no Paraguai: uma análise crítica. Rio de Janeiro, 2014. 205 p. Dissertação de Mestrado - Instituto de Relações Internacionais, Pontifícia Universidade Católica do Rio de Janeiro.

Nas últimas décadas, o modelo do agronegócio consolidou-se no Paraguai a partir da ampla participação de forças econômicas estrangeiras, especialmente, de origem brasileira, dando lugar a uma estrutura peculiar, com implicações sociopolíticas particulares. O principal objetivo desta dissertação é discutir sobre o papel desses capitais, empresários e produtores brasileiros no desenvolvimento do agronegócio no Paraguai. Para isso, o estudo parte de uma perspectiva geral, localizando o fenômeno no marco da expansão da agricultura capitalista (ou agronegócio) em nível mundial, o que permite avançar uma compreensão mais completa sobre as causas e características da presença brasileira no Paraguai. Tal abordagem é inspirada nas reflexões das teorias da dependência - principalmente, da chamada "vertente marxista" e das premissas a respeito do fenômeno do subimperialismo - que entendem que o desenvolvimento econômico dos países latino-americanos é fortemente determinado pelo desenvolvimento da economia (capitalista) mundial, processo que engendra dinâmicas de diferenciação socioeconômica entre e dentro dos países que se integram a esse sistema. Dessa forma, argumenta-se que o fenômeno analisado é resultado do desenvolvimento desigual da agricultura capitalista no Brasil e no Paraguai, onde o primeiro experimenta um maior desenvolvimento relativo que se reflete na sua expansão externa. Capitais e empresários brasileiros passam, então, a participar do desenvolvimento do agronegócio no Paraguai. Assumem, contudo, um papel intermediário, pois, ao mesmo tempo em que dominam certos segmentos da estrutura produtiva, subordinam-se às determinações das corporações transnacionais do agronegócio, que controlam o ritmo do desenvolvimento do agronegócio em nível global.

\section{Palavras-chave}

Agronegócio; Paraguai; Brasil; economia capitalista mundial; desenvolvimento desigual; dependência; subimperialismo. 


\section{Abstract}

Garay, Sara María Costa; Gómez, José Maria (Advisor). Brazilian participation in the development of agribusiness in Paraguay: a critical analysis. Rio de Janeiro, 2014. 205 p. MSc. Dissertation Instituto de Relações Internacionais, Pontifícia Universidade Católica do Rio de Janeiro.

In the last decades, the agribusiness model consolidated in Paraguay with a broad participation of foreign economic forces, especially, of Brazilian origin, giving way to a peculiar structure, with specific social and political implications. The main purpose of this dissertation is to discuss about the role of those Brazilian capitals, entrepreneurs and farmers in the development of agribusiness in Paraguay. To that end, the study departs from a general perspective, locating the phenomenon in the context of the expansion of the capitalist agriculture (or agribusiness) at a world level, which allows us to advance towards a more complete understanding about the causes and characteristics of the Brazilian presence in Paraguay. Such an approach is inspired by assumptions from the dependency theories - mainly, from its Marxist view and from the premises regarding the phenomenon of subimperialism - that consider that the economic development of Latin-American countries is strongly determined by the development of the world (capitalist) economy, a process that generates dynamics of socioeconomic differentiation between and within the countries that integrate with that system. Thus, we argue that the phenomenon under analysis is a result from the unequal development of the capitalist agriculture in Brazil and in Paraguay, where the first experiences a relatively more advanced development that is reflected in its foreign expansion. Brazilian capital and entrepreneurs then participate in the development of agribusiness in Paraguay. They assume, however, an intermediary role, since, while controlling certain sectors of the productive structure, they are subordinated to the determinations of transnational corporations, which control the pace of agribusiness development at a global level.

\section{Keywords}

Agribusiness; Paraguay; Brazil; capitalist world economy; unequal development; dependency; subimperialism. 


\section{Sumário}

1. Introdução

16

2. O desenvolvimento da economia capitalista mundial e seus matizes na América Latina: a contribuição das teorias da dependência

2.1 A gênese da (s) teoria (s) da dependência 23

2.1.1 A vertente marxista das teorias da dependência 30

2.2 As teorias da dependência na era da globalização 35

2.2.1 Neoliberalismo vs. Neodesenvolvimentismo vs. Dependência 38

2.3 Nuances no esquema da dependência: a emergência do subimperialismo

2.3.1 Atualidade da teoria e do fenômeno do subimperialismo brasileiro

3. O desenvolvimento da agricultura capitalista e a sua expansão na América Latina

3.1 Da Revolução Verde à Revolução Biotecnológica: o desenvolvimento da agricultura moderna sob o comando estadunidense

3.2 Globalização neoliberal, cadeias agro-alimentares globais e corporações transnacionais: a configuração das relações internacionais contemporâneas no âmbito da agricultura

3.3 O fenômeno do landgrabbing

4. A expansão do agronegócio no Cone Sul: integração imperialista e desenvolvimento desigual 
4.3 Brasil: a potência regional do agronegócio

4.3.1 O Paraguai na órbita regional do agronegócio liderada pelo Brasil

5. A participação brasileira no desenvolvimento do agronegócio no Paraguai: trajetória e contexto atual

5.1 O desenvolvimento da agricultura moderna no Paraguai (1960-1980)

5.2 modelo do agronegócio no Paraguai: estrutura e dinâmicas atuais

5.2.1 A configuração da cadeia do agronegócio

5.2.2 Concentração e "estrangeirização" da terra

5.3 A expansão do agronegócio e da presença brasileira no Paraguai: dinâmicas de alianças e conflitos

5.4 Considerações finais do capítulo

6. Considerações finais 


\section{Lista de Figuras}

Figura 1 - Cadeia de valor global do agronegócio e as economias em desenvolvimento

Figura 2 - Fluxos de IED (inward) na agricultura e agroindústria (1990-2007) - US\$ bilhões

Figura 3 - IED acumulada em agricultura na América Latina (2005-2011) - Países selecionados - Em percentagem (\%) do total de IED acumulado por cada país

Figura 4 - Geopolítica da questão agrária mundial: Mapa dos arrendamentos e/ou compras de terras para a produção de alimentos e agroenergía

Figura 5 - Cadeia global do agronegócio da soja

Figura 6 - Principais exportadores de soja em grão (2012/2013)

Em mil toneladas métricas e percentagem do total mundial

Figura 7 - Principais importadores de soja em grão (2012/2013)

Em mil toneladas métricas e percentagem do total mundial

Figura 8 - Mapa do Paraguai

Figura 9 - Fluxos de IED no Paraguai (1990-2012)

Figura 10 - Expansão da superfície e produção de soja no Paraguai

Figura 11 - Mapa dos departamentos com maior número de proprietários estrangeiros (nos lotes acima de 1mil hectares) - 2008

Figura 12 - Quantidade de hectares (em \%) cultivados de soja por nacionalidade de produtores e tamanho das propriedades Ano 2008

Figura 13 - As 10 maiores empresas de sementes do mundo (2011) 178

Figura 14 - As 11 maiores empresas agroquímicas do mundo (2011) 178

Figura 15 - Os latifúndios na fronteira paraguaia por volta de 1950 


\section{Lista de Tabelas}

Tabela 1 - As dez maiores firmas transnacionais da cadeia global do agronegócio em 2007

Tabela 2 - As onze maiores firmas transnacionais processadoras/ comerciantes de sementes oleaginosas, grãos e/ou açúcar em 2009

Tabela 3 - Fluxos estimados de IED (inward) para a agricultura e agroindústria - Em bilhões de dólares e percentagem

Tabela 4 - Fluxos de IED (inward) globais em agricultura e países selecionados

Tabela 5 - Perfil agrário-econômico dos países do Cone Sul

Tabela 6 - Fluxos de IED (inward) para os países do Cone Sul (2000 e 2011)

Tabela 7 - Crescimento da superfície (em hectares) e da produção de soja (em toneladas) nos países do Cone Sul

Tabela 8 - Evolução da produção mundial de soja e participação relativa dos principais países produtores

Tabela 9 - Participação do Complexo da Soja nas exportações totais dos países do Cone Sul (2012)

Tabela 10 - Padrão de intercâmbio comercial Brasil-Paraguai

Anos selecionados

Tabela 11 - Corporações transnacionais do agronegócio estabelecidas no Paraguai

Tabela 12 - Exportações totais das corporações transnacionais do agronegócio instaladas no Paraguai (2009-2013)

Tabela 13 - Distribuição percentual de proprietários individuais de acordo com a nacionalidade por departamento - Lotes acima de mil ha. - Ano de 2008

Tabela 14 - Terras compradas por empresários estrangeiros (acima de 1000 ha.) nas regiões de "estrangeirização intensiva" (2006-2010) 142

Tabela 15 - Utilização do grão de soja no Paraguai (1989-2013)

- Em toneladas 
Tabela 16 - Produção e exportação de máquinas agrícolas no Brasil (2000-2012) - Em unidades

Tabela 17 - Balança comercial brasileira de máquinas agrícolas (2001-2012) - US\$ milhões

Tabela 18 - Evolução do intercâmbio comercial de bens entre

Paraguai e Brasil (1990-2012) - Em Miles de US\$/FOB

Tabela 19 - Fluxos de IED no Paraguai por atividade (2003-2012) e estoque de IED por atividade (2012)

Tabela 20 - Estoque acumulado de IED (2012) nas atividades Agrícolas e agroindustriais no Paraguai - Em Miles de US\$

Tabela 21 - Corporações transnacionais do agronegócio instaladas no Paraguai -2013

Tabela 22 - Outras empresas estrangeiras do agronegócio instaladas no Paraguai -2013

Tabela 23 - Empresas locais do agronegócio no Paraguai - 2013

Tabela 24 - Principais cooperativas de produção do Paraguai - 2013198

Tabela 25 - Importações totais das transnacionais atuantes no segmento de fornecimento de insumos no Paraguai (2009-2013)

Tabela 26 - Exportações totais das cinco maiores empresas do grupo "Outras firmas estrangeiras do agronegócio" (2009-2013)

Tabela 27 - Exportações e importações das empresas "brasiguaias" (2009-2013)

Tabela 28 - Importações totais das empresas locais do agronegócio (2009-2013)

Tabela 29 - Exportações totais das empresas locais do agronegócio (2009-2013)

Tabela 30 - Exportações totais das cooperativas de produção do Paraguai (2009-2013) 


\section{Abreviaturas e Siglas}

ABIOVE - Associação Brasileira das Indústrias de Óleo Vegetal

ANFAVEA - Associação Nacional dos Fabricantes de Veículos Automotores

APS - Asociación de los Productores de Soja

ARP - Asociación Rural Del Paraguay

BCP - Banco Central do Paraguay

BID - Banco Interamericano de Desenvolvimento

BNDES - Banco Nacional de Desenvolvimento Econômico e Social

BRICS - Brasil, Rússia, Índia, China e África do Sul

CAN - Censo Agropecuário Nacional

CAPECO - Cámara Paraguaya de Exportadores y Comercializadores de Cereales y Oleaginosas

CAPPRO - Cámara Paraguaya De Procesadores y Exportadores de Oleaginosas y Cereales

CEPAL - Comissão Econômica Para América Latina

CESO - Centro de Estudios Socio-económicos (Universidade de Chile)

CIP - Centro de Importadores del Paraguay

DIT - Divisão Internacional do Trabalho

EMBRAPA - Empresa Brasileira de Pesquisa Agropecuária

EUA - Estados Unidos da América

EU - União Europeia

FAO - Organização das Nações Unidas para Alimentação e Agricultura

FECOPROD - Federación de Cooperativas de la Producción

FIESP - Federação das Indústrias do Estado de São Paulo

FHC - Fernando Henrique Cardoso

IED - Investimento Estrangeiro Direto 
IBD - Investimento Brasileiro Direto

IBR - Instituto de Bienestar Rural

INDERT - Instituto Nacional de Desarrollo Rural y de la Tierra

IVA - Impuesto al valor agregado

MAG - Ministerio de Agricultura y Ganadería

MDIC - Ministério do Desenvolvimento, Indústria e Comercio Exterior

MERCOSUL - Mercado Comum do Sul

OMC - Organização Mundial do Comércio

PIB - Produto Interno Bruto

UGP - Unión de Gremios de la Producción

UNCTAD - Conferência das Nações Unidas sobre o Comércio e o Desenvolvimento

USDA - Departamento de Agricultura dos Estados Unidos 


\section{1. Introdução}

Nas últimas décadas, a expansão da agricultura capitalista - ou do agronegócio, como é comumente denominada - nos países da América Latina tem provocado impactos significativos na organização econômica dessas sociedades e nas suas relações com a economia mundial. Sob o comando das corporações transnacionais, esse processo resultou em uma acelerada modernização das formas de produção no campo, que se tornaram mais intensivas no uso de capital e energia, em detrimento da utilização de mão de obra, e no reforço do padrão agroexportador nesses países. Todavia, esses impactos adquirem graus e formas distintas de acordo com a sociedade em questão, derivando em implicações sociais e políticas particulares.

O Paraguai é um dos países onde o avanço do agronegócio tem adquirido ampla notoriedade - atualmente, o país se coloca como sexto produtor mundial e quarto exportador mundial de soja - e onde o modelo assume uma configuração peculiar decorrente, fundamentalmente, de sua vinculação com o desenvolvimento da agricultura moderna no Brasil. Além de estar organizado em função das estruturas globais de produção e circulação de bens agrícolas e alimentos, comandadas e oligopolizadas pelas firmas transnacionais do agronegócio similarmente aos sistemas produtivos agrícolas dos demais países da região - o modelo do agronegócio no Paraguai se estrutura a partir da participação de capitais, empresários e produtores rurais de origem brasileira. A presença desses agentes econômicos brasileiros, que se aprofunda, principalmente, desde os anos 1970, é um traço marcante do processo de desenvolvimento rural paraguaio, assim como das dinâmicas sociopolíticas em torno da questão agrária no país, constituindo um caso interessante de estudo.

O presente trabalho se insere nessa temática, buscando compreender o papel desses capitais, empresários e produtores brasileiros no desenvolvimento do agronegócio no Paraguai. Diversos estudos realizados, principalmente, no âmbito da sociologia rural, têm abraçado essa tarefa. Em geral, convergem em ressaltar a função central dessas forças econômicas brasileiras na expansão da fronteira 
agrícola e na incorporação de novas técnicas e tecnologias ao processo de produção agrícola no Paraguai. Isto é, são apontados como os principais agentes da difusão do modelo da agricultura capitalista no país desde os anos 1970. Esse fenômeno é comumente citado na literatura sobre o tema como o processo de "colonização brasileira", que também faz referência à transferência massiva de produtores e fazendeiros brasileiros para o território paraguaio que aconteceu naquele período. Outros estudos, que versam mais sobre o contexto atual, enfatizam o vasto controle que os produtores brasileiros têm sobre a produção dos principais bens agrícolas de exportação (principalmente, da soja), argumentando que essa situação corresponde à consolidação de novas economias de enclave em referência ao formato característico de instalação do capital estrangeiro no início do século XX.

As contribuições dessas análises são cruciais para compreender a atuação dos capitais, empresários e produtores brasileiros na consolidação do agronegócio no Paraguai. Todavia, na maior parte desses estudos, o foco recai sobre as dinâmicas do uso e apropriação da terra que, embora relevantes, acabam deixando pouco espaço para analisar a vinculação dos agentes econômicos brasileiros com a atuação de outros importantes atores do modelo do agronegócio, como as firmas transnacionais - que, em geral, têm uma inserção mais indireta, porém determinante, na dinâmica da produção agropecuária. Por outro lado, grande parte dos estudos sobre tema data dos primeiros anos de emergência do fenômeno (nas décadas de 1960, 1970 e 1980). Desde então, a presença brasileira na economia agrária do Paraguai tem passado por mutações que precisam ser ressaltadas e analisadas. Ainda são escassos os trabalhos que procuram realizar essa tarefa.

Diante desse panorama, surge então a necessidade de realizar um estudo do fenômeno em questão considerando um enfoque espacial e temporal mais amplo, que consiga abranger as múltiplas relações em jogo, assim como a evolução das mesmas ao longo do tempo. Assim, o principal objetivo deste trabalho é discutir sobre o papel dos capitais, empresários e produtores brasileiros no desenvolvimento do agronegócio no Paraguai. Para isso, o estudo parte de uma perspectiva geral, localizando o fenômeno no marco da expansão da agricultura capitalista a nível mundial, o que permite avançar uma compreensão mais completa sobre as causas e características da presença brasileira no Paraguai. Deste modo, a consolidação do modelo do agronegócio no Paraguai e a 
participação brasileira nesse processo são analisadas vis-à-vis às tendências e os padrões da expansão desse modelo em nível mundial e regional, com o intuito de distinguir como essas dinâmicas se determinam mutuamente.

Tal abordagem é inspirada nas reflexões das teorias da dependência, principalmente, da chamada "vertente marxista", que entendem que o desenvolvimento econômico dos países latino-americanos é fortemente determinado pelo desenvolvimento da economia (capitalista) mundial, processo altamente oligopolizado por certas sociedades e agentes econômicos, que engendra dinâmicas de diferenciação socioeconômica entre e dentro dos países que se integram a esse sistema - resultando no esquema centro-periferia, ou na divisão entre países centrais e países dependentes. Dentro desse esquema teórico, as premissas a respeito do fenômeno do "subimperialismo" - conforme elaboradas por Ruy M. Marini, e atualizadas por autores como Jaime Osório e Mathias Luce - ganham destaque, na medida em que abrem espaço para pensar sobre as dinâmicas de diferenciação entre as próprias sociedades dependentes (ou periféricas) latino-americanas - especificamente, entre o Brasil e os demais países da região da América do Sul - que emergem no marco das reestruturações econômicas que assinalam a contínua expansão da economia capitalista mundial.

Esse núcleo teórico é complementado com contribuições de outras disciplinas, como a Sociologia Rural, dedicadas mais intensamente ao estudo dos processos em torno da agricultura - atividade que, em geral, recebeu menor atenção no âmbito da Economia Política, mais orientada para as questões urbanoindustriais. Dessa forma, consegue-se indicar as particularidades do desenvolvimento do modelo de agricultura capitalista (ou agronegócio) e da sua expansão mundial, que também incide nas redefinições da divisão internacional do trabalho. Por exemplo, um aspecto central desse novo modelo de agricultura é que as atividades não se restringem à esfera da produção em si (isto é, do cultivo da terra), mas estabelece uma cadeia de processos relacionados que se estendem desde a elaboração de insumos tecnológicos para a produção, até a distribuição para o consumidor final. Esse esquema ajuda a descrever como acontece a organização da produção e circulação de bens agrícolas e alimentos atualmente, tanto em nível local como global, permitindo evidenciar como se configura a divisão internacional de trabalho, e as relações de subordinação decorrentes, no âmbito da agricultura. 
Com base nesse marco teórico interdisciplinar, que possibilita a adoção de uma perspectiva ampliada para a análise dos dados, argumenta-se que o fenômeno em questão é resultado de um desenvolvimento desigual da agricultura capitalista no Brasil e no Paraguai, onde o primeiro experimenta um maior desenvolvimento relativo, que se reflete na sua expansão externa. Capitais, empresários e produtores brasileiros passam então a participar do desenvolvimento do agronegócio no Paraguai assumindo, contudo, um papel de intermediário, pois, ao mesmo tempo em que dominam certos segmentos da estrutura produtiva (como a produção de soja), subordinam-se às determinações das corporações transnacionais do agronegócio, que controlam o ritmo da atividade em nível global. Em termos de seu peso social e político, entretanto, os agentes econômicos brasileiros, apesar de constituírem o "elo fraco" da cadeia (referente ao segmento da produção), representam o rosto mais visível do avanço do agronegócio no país, sendo o principal alvo de denúncias e reivindicações por parte dos excluídos do modelo. Conclui-se, assim, que se trata de um fenômeno complexo e heterogêneo.

Essas e outras considerações foram elaboradas a partir de extensas reflexões teóricas e análises de dados que, no presente trabalho, são organizadas e apresentadas em quatro capítulos. Enquanto os primeiros dois capítulos se referem à montagem da base teórico-conceitual, buscando construir o enfoque ampliado que se deseja avançar neste trabalho, os demais capítulos consistem na apresentação e análise de dados atuais sobre as tendências do agronegócio em nível global, regional e, especificamente, no Paraguai. Conclusões gerais e reflexões finais sobre o trabalho são apresentadas ao final, ao lado de recomendações para futuras pesquisas sobre o tema.

O primeiro capítulo tem como finalidade apresentar e discutir o marco teórico que sustentou as análises ao longo desta pesquisa, composto pelas premissas da "vertente marxista" das teorias da dependência, em especial, da teoria do subimperialismo, que permitem compreender o caráter da inserção das sociedades latino-americanas na dinâmica econômica mundial - notadamente, em condições de subordinação aos interesses dos oligopólios internacionais - e as especificidades do desenvolvimento do capitalismo nesses países, processo marcado por dinâmicas particulares que derivam dessa condição de dependência do capital internacional. Na medida em que essa corrente teórica foi, diversas vezes, marginalizada nos debates públicos e acadêmicos, o capítulo a apresenta 
realizando, em primeiro lugar, uma breve revisão histórica do surgimento das diferentes vertentes do pensamento social latino-americano dedicadas a pensar a questão do desenvolvimento dos países da região, no intuito de apontar os principais debates travados e clivagens entre as mesmas. Da mesma forma, o capítulo se preocupa em ressaltar a relevância atual dessas contribuições, a despeito da especificidade histórica de seu surgimento.

Conforme mencionado anteriormente, uma vez que o trabalho versa sobre a temática da agricultura, esse marco teórico precisou ser complementado com contribuições de outras disciplinas que ajudassem a explicar e compreender as dinâmicas específicas do desenvolvimento da agricultura capitalista (ou do modelo do agronegócio) e de sua expansão (desigual) em nível mundial. O segundo capítulo é dedicado ao resgate dessas contribuições, mostrando que as dinâmicas da organização da produção e circulação de alimentos e matérias primas agrícolas em nível mundial são uma parte essencial da determinação dos processos de desenvolvimento dos países latino-americanos, e de sua inserção (subordinada) na economia mundial - isto é das (re) configurações da divisão internacional do trabalho e das relações de dependência.

No terceiro capítulo, apresentam-se dados a respeito das principais tendências que marcam a expansão do agronegócio na América Latina, especialmente, nos países do Cone Sul - como o aumento dos fluxos de Investimento Estrangeiro Direto (IED) na região, e o crescimento da produção e exportação de commodities agrícolas, principalmente da soja. Ressalta-se também o predomínio das corporações transnacionais na organização e ampliação das cadeias de produção agrícola e agroindustrial na região, indicando que esses países experimentam um padrão similar de integração (subordinada) a essas cadeias, passando pelos mesmos processos de internacionalização e desnacionalização de seus sistemas produtivos. Por outro lado, o capítulo busca apontar nessas análises evidências de um processo de integração diferenciada dos países em questão à dinâmica global do agronegócio, isto é, evidências de um processo de desenvolvimento desigual do modelo da agricultura capitalista nesses países, e da instalação de uma divisão regional (desigual) do trabalho, que expliquem o movimento de expansão de capitais e produtores brasileiros para o Paraguai. De fato, verifica-se que o Brasil tem se colocado como destino preferencial na região do IED agrícola, além de destacar-se em diversos ramos da 
atividade agroindustrial, dedicando-se assim uma seção específica à análise do caso brasileiro. No final do capítulo, é possível inferir o porquê da presença brasileira na estrutura do agronegócio no Paraguai ser mais contundente no segmento da produção primária, traçando-se algumas considerações ao respeito.

No quarto capítulo, realiza-se a análise mais específica a respeito da configuração da cadeia do agronegócio no Paraguai, apontando para os principais agentes econômicos por trás da promoção do modelo (tanto de origem estrangeira como local) e os principais ramos desenvolvidos no país, com destaque para os capitais, empresários e produtores brasileiros e seus principais segmentos de atuação. Em primeiro lugar, faz-se uma breve revisão histórica a respeito da emergência do fenômeno em questão - priorizando trabalhos realizados desde a perspectiva paraguaia - a fim de distinguir as principais diferenças com relação aos padrões atuais da expansão brasileira no país - como a diminuição no ritmo da migração de produtores, e a expansão dos investimentos para novos ramos do agronegócio (como a produção e processamento de carne). De qualquer forma, o principal segmento de atuação dos capitais e empresários brasileiros continua a ser a produção primária (e o cultivo de soja, essencialmente), ao passo que os demais segmentos, como o de fornecimento de insumos tecnológicos e os de coleta e processamento dos bens agrícolas, são amplamente controlados pelas firmas transnacionais - e daí o lugar secundário que ocupam na promoção do modelo do agronegócio no Paraguai. A última seção do capítulo é dedicada a uma breve análise das dinâmicas sociopolíticas que circunscrevem a consolidação do modelo do agronegócio e da presença brasileira no país, a fim de aprofundar o entendimento sobre seu peso social e político, que adquire maior transcendência.

Em suma, este trabalho nasceu do anseio de compreender melhor um fenômeno complexo e polêmico da realidade paraguaia, propondo a utilização de um marco interpretativo amplo e multidisciplinar, com o intuito de abranger as ambiguidades do caso. Dessa forma, além de contribuir para os estudos sobre o tema - especialmente, para um melhor entendimento da questão agrária no Paraguai - o trabalho espera enriquecer o debate atual em torno da questão da dependência e do subimperialismo, sobretudo, no que diz respeito ao resgate da esfera da agricultura, que constitui um eixo estratégico da expansão do capital e da dominação imperialista, hoje, mais do que nunca, nos países da América Latina. 


\section{2. \\ O desenvolvimento da economia capitalista mundial e seus matizes na América Latina: a contribuição das teorias da dependência}

O entendimento dos processos socioeconômicos de um determinado país passa por uma compreensão das características de sua inserção na economia mundial, sistema ao qual as sociedades se integram de forma desigual, assumindo posições e funções específicas. Esse aspecto foi amplamente ressaltado por uma série de estudos que emergiram a partir da segunda metade do século $\mathrm{XX}$, orientados a desvendar as peculiaridades do desenvolvimento econômico das sociedades latino-americanas.

O presente capítulo destaca um conjunto específico dentre essas análises que ficaram conhecidas como teorias da dependência. A questão da dependênciareferente à condição de subordinação das estruturas produtivas dos países menos desenvolvidos (ou da periferia da economia mundial) às determinações dos monopólios internacionais, controlados pelos países desenvolvidos (do centro) foi amplamente debatida, gerando diferentes visões sobre essa problemática. Neste capítulo, coloca-se maior ênfase nas contribuições da chamada "vertente marxista" da dependência, que constituem o marco teórico do presente trabalho ${ }^{1}$.

Na medida em que essas teorias sofrem certo prejuízo nos debates públicos e acadêmicos atuais, o capítulo as apresenta realizando, em primeiro lugar, uma breve revisão do contexto histórico de seu surgimento, apontando para as diversas abordagens elaboradas a respeito da questão do desenvolvimento econômico dos países da América Latina e para as principais clivagens entre as mesmas. Dessa forma, é possível distinguir as críticas que foram avançadas pelas teorias da dependência, especialmente, pela vertente marxista, na época de seu surgimento. Seguidamente, discute-se sobre as tendências atuais de resgate e atualização dessas teorias, que ganham impulso em meio a um contexto de acirramento das desigualdades dentro da economia mundial e da necessidade de oferecer visões

\footnotetext{
${ }^{1}$ No presente trabalho, a discussão sobre as diferentes versões da questão da dependência se baseia no trabalho de C. E. Martins (2006, 2012), que distingue duas vertentes principais: a "weberiana" e a "marxista". Os principais pressupostos e expoentes de cada uma são apresentados mais adiante.
} 
mais críticas a respeito dos fenômenos econômicos contemporâneos. Assim, consegue-se apreciar a relevância histórica e atual do marco teórico da dependência - frequentemente menosprezado ou mal interpretado - e ressaltar-se a riqueza dos debates em torno dessa questão.

Dentre as contribuições da chamada "vertente marxista" da dependência, as discussões sobre o fenômeno do "subimperialismo", conforme teorizado por Ruy M. Marini, recebem atenção especial, uma vez que versam sobre dinâmicas mais específicas derivadas do processo de expansão (desigual) da economia capitalista mundial, particularmente, sobre a trajetória de desenvolvimento econômico do Brasil e de seus países vizinhos - lançando luz sobre o caso a ser analisado no presente trabalho. Portanto, após a discussão geral sobre o surgimento e relevância atual das teorias da dependência, as duas últimas seções do capítulo são destinadas a apresentar a discussão (histórica e atual) sobre a teoria e o fenômeno do subimperialismo.

\section{1}

\section{A gênese da (s) teoria (s) da dependência}

A questão do desenvolvimento foi um tema que emergiu com força na agenda política e acadêmica internacional no período de reestruturação econômica mundial após a Segunda Guerra Mundial ${ }^{2}$. Nesse contexto, o pensamento social latino-americano ganhou ampla transcendência a partir da elaboração de perspectivas que buscavam ressaltar as particularidades dos processos de desenvolvimento socioeconômico dos países da região. Entre os anos 1950 e 1970, a proliferação dessas perspectivas atingiu grande dinamismo, avançando diferentes abordagens sobre a problemática da falta de desenvolvimento nesses países, mas que, em geral, compartilhavam uma visão holística e histórica da realidade orientada a superar o reducionismo das ontologias nacionalistas e etnocêntricas das teorias do desenvolvimento difundidas até então.

\footnotetext{
${ }^{2}$ Em linhas gerais, esse contexto foi marcado pela ascensão dos Estados Unidos à posição de potência hegemônica no mundo capitalista, concomitantemente à consolidação da URSS como economia hegemônica no mundo socialista, constituindo assim o cenário da Guerra Fria e da ordem "bipolar". Ao longo desse período (entre 1945 e 1991), ambos os países competiram intensamente para a ampliação e consolidação de seus modelos socioeconômicos ao redor do mundo. A participação dos Estados Unidos na reconstrução dos países da Europa ocidental afetados pela guerra, e a extensão de sua presença nos países da América Latina - principalmente, após os eventos da Revolução Cubana (1959) - se inseriram nessa dinâmica.
} 
Em um primeiro momento, o debate ganhou fôlego com a divulgação de um conjunto de premissas que ficaram conhecidas como o paradigma do "estruturalismo latino-americano" (Beigel, 2006; Kay, 2009) ou do "nacionaldesenvolvimentismo" (Martins, 2006; 2012; Wagner 2009), e que tiveram na Comissão Econômica Para América Latina (CEPAL) - fundada em 1948 - seu principal canal de difusão ${ }^{3}$. De acordo com Martins (2006), esse paradigma se caracterizou por avançar uma forte crítica ao liberalismo econômico e à teoria das vantagens comparativas, propondo uma reinterpretação das relações econômicas internacionais e do papel da América Latina nessa dinâmica. Em lugar de um equilíbrio nas trocas comerciais entre os países, o que se verificava era a existência de um esquema de "intercâmbio desigual" entre o "centro" (conformado por países industrializados) e a "periferia" (composta pelos países não industrializados) do sistema econômico, onde as nações do segundo grupo viam seu processo de desenvolvimento ser prejudicado por esse esquema.

Para os proponentes do estruturalismo latino-americano, o intercâmbio desigual era o resultado de uma tendência de queda dos preços dos produtos primários (produzidos na periferia) com relação aos produtos industrializados (produzidos no centro), descrito como o fenômeno da "deterioração dos termos de troca". Assim, em vez de acontecer uma distribuição equitativa dos ganhos gerados pelo progresso técnico (industrialização) nos países do centro entre todas as nações envolvidas na divisão internacional do trabalho por meio das trocas comerciais - como previa a teoria econômica clássica - na prática, verificava-se um processo constante de descapitalização dos países periféricos.

$\mathrm{O}$ estímulo à industrialização, com a consequente mudança que isso provocaria na composição das exportações dos países periféricos, surgia então como solução para contornar a problemática do intercâmbio desigual e da transferência de valores. Em vista das condições instaladas, esse processo demandaria um forte envolvimento do Estado para a canalização de recursos em torno de um projeto de industrialização. A maior presença do Estado, contudo, não implicava em uma exclusão do capital estrangeiro desse projeto, pelo contrário, a sua participação era considerada indispensável, principalmente, para

3 O texto "El desarrollo económico de la América Latina y algunos de sus principales problemas", publicado originalmente em 1949, e escrito pelo economista argentino e então secretario executivo da CEPAL Raúl Prebisch, foi considerado como o principal manifesto dessas novas premissas. 
complementar os esforços nacionais de geração de poupança e conseguir financiar os projetos de industrialização. Em última instância, essas análises concebiam a possibilidade de um "catch-up" dos países periféricos com os países industrializados, a despeito das limitações inicialmente encontradas.

Ao longo dos anos de austeridade na economia internacional - no período entre guerras - diversos países da América Latina haviam experimentado um processo incipiente de industrialização, conhecido como a época da "substituição das importações". No novo contexto de reorganização econômica, após a Segunda Guerra Mundial, o objetivo dos políticos e intelectuais afiliados ao nacionaldesenvolvimentismo era transformar esse processo de caráter espontâneo, em um projeto de longo prazo. Assim, ao longo das décadas de 1950 e 1960, diversas políticas de industrialização foram testadas, especialmente nos países de maior desenvolvimento relativo, como Brasil e Argentina.

Com o passar do tempo, e na medida em que, apesar dos esforços realizados, a "falta de desenvolvimento" (ou o subdesenvolvimento) persistia nas economias latino-americanas, as teorias do nacional-desenvolvimentismo deixaram em evidência as suas limitações para a compreensão e superação dessa problemática. De acordo com Beigel (2006), nesse contexto de crise, novas formulações teóricas começaram a ganhar forma, orientando-se para uma ruptura mais radical com os enfoques desenvolvimentistas e modernizadores que, ao longo da década de 1950, haviam dirigido suas expectativas para a industrialização. Dessa forma, na segunda metade da década de 1960, presencia-se à ascensão das chamadas teorias da dependência, que marcavam um novo esforço de reinterpretação das relações econômicas internacionais e das mudanças em curso nas estruturas socioeconômicas dos países da América Latina desde a segunda metade do século XX.

\footnotetext{
${ }^{4}$ Isto é, concebiam a possibilidade de que os países periféricos alcançassem a condição de países desenvolvidos, recuperando-se do atraso. Nesse sentido, o estruturalismo latino-americano mostrava afinidade com as chamadas "teorias da modernização", que também concebiam o desenvolvimento como um processo linear, e a situação de subdesenvolvimento como uma etapa anterior ao desenvolvimento pleno, onde a transição seria pautada, basicamente, por um constante aprofundamento da modernização das atividades econômicas. Todavia, é preciso ressaltar que, o nacional-desenvolvimentismo latino-americano, ao resgatar a especificidade histórica das nações latino-americanas e adotar uma visão mais estrutural (propondo o esquema centro-periferia), ia além das formulações ahistóricas e etnocêntricas que caracterizava grande parte das teorias da modernização, as quais elaboravam suas premissas com base na experiência das nações industrializadas, atribuindo-lhes um caráter universal.
} 
A principal divergência com relação às noções do nacionaldesenvolvimentismo consistia na compreensão da existência de sociedades industrializadas e não industrializadas não como representações das diferentes etapas do processo de desenvolvimento de uma nação, mas como resultados simultâneos de um mesmo processo: o desenvolvimento da economia (capitalista) mundial.

\begin{abstract}
A teoria da dependência, por seu turno, partirá de novas perspectivas, tomando o capitalismo como um sistema mundial, não considerando o desenvolvimento como etapas de um continuum, mas como realidades distintas e contrapostas estruturalmente, vinculadas uma a outra (Wagner, 2009:63).
\end{abstract}

Nesse esquema, o desenvolvimento da economia capitalista em nível mundial engendrava um sistema de relações hierarquizadas entre os países e suas estruturas e agentes econômicos. De um lado, constituíam-se monopólios internacionais que comandavam a expansão e circulação mundial de capitais e tecnologias, e respondiam pelas dinâmicas de desenvolvimento econômico dos países centrais. Do outro lado, os diferentes aparelhos produtivos, comerciais e financeiros nacionais da periferia do sistema se articulavam a essa dinâmica atendendo aos interesses dos monopólios internacionais, caracterizando assim uma situação de subordinação (ou de "dependência"). Os teóricos da dependência reconheciam, então, a existência do esquema da divisão entre "centro e periferia" - ou, no caso, entre países centrais e países dependentes - mas, essa distinção fazia referência a dois polos complementares, isto é, a dois conjuntos que se reproduziam mutuamente.

O papel do capital internacional e a sua expansão nos países latinoamericanos, a partir da segunda metade do século XX, adquiriam então um novo sentido:

O novo papel que o capital estrangeiro passa a cumprir muda decididamente a estrutura socioeconômica dos países latino-americanos. (...) Para estas empresas [filiais das multinacionais estadunidenses ou europeias que se instalam nesses países], não está em pauta o desenvolvimento autônomo ou preocupações que tangem a aspectos da soberania nacional do país em que atua, mas, encontrar as melhores condições para a reprodução ampliada de seu capital. Ocupando cada vez mais espaços e um papel central no mecanismo de crescimento industrial, essas empresas passam a controlar o ritmo em que este se desenvolve. Dá-se um processo de integração cada vez maior entre o capital estrangeiro e as economias nacionais, que resulta no aprofundamento da dependência dos últimos em relação aos primeiros (Wagner, 2009:61. Grifos nossos). 
Dessa forma, os teóricos da dependência argumentavam que os países dependentes (ou periféricos) experimentavam um processo de desenvolvimento que não representava um estágio inferior em uma escala única de desenvolvimento, ainda a ser superado, mas constituíam trajetórias específicas dentro da formação da economia capitalista mundial. Nessa mesma linha, defendiam que os países latino-americanos deveriam ser considerados como economias capitalistas plenas, ainda que adotassem formatos particulares ${ }^{5}$. Ao admitir que o desenvolvimento do capitalismo nesses países adquiria características específicas, as relações de hierarquização e subordinação (ou de dependência) passaram então a ser analisadas para além das suas manifestações no nível internacional (isto é, entre países). Conforme explica Martins (2006:171), para esses teóricos, a dependência significava assim a existência de uma "estrutura econômica, social, política e ideológica, simultaneamente nacional, internacional e específica dentro da economia mundial".

Ao problematizar questões mais complexas a respeito da articulação econômica entre os diferentes países - e sobre suas respectivas dinâmicas socioeconômicas - as teorias da dependência abriam um novo caminho para a compreensão das limitações dos processos de desenvolvimento das nações latinoamericanas e das soluções que haviam sido propostas pelos defensores do nacional-desenvolvimentismo para a superação dos problemas. Dentre os diversos apontamentos, os dependentistas concluíram que a industrialização per se não resultaria em uma superação automática da condição de subordinação na economia mundial - ou na solução dos problemas sociais oriundos do subdesenvolvimento - na medida em que esse processo estava sendo amplamente comandado pelos interesses dos monopólios internacionais.

Todavia, é preciso ressaltar que as teorias da dependência compõem um grupo heterogêneo. Enquanto os delineamentos apresentados anteriormente representam seu núcleo central comum, emergiram importantes clivagens dentro do grupo. Tais divergências precisam ser destacadas, pois, diversas vezes, o

\footnotetext{
${ }^{5}$ Ou seja, as particularidades das estruturas socioeconômicas dos países dependentes não eram interpretadas como sinais de um "atraso", mas, como as marcas de uma trajetória particular do desenvolvimento capitalista em seus territórios. O capitalismo dos países dependentes recebeu assim diversos nomes, como capitalismo "sui generis", "dependente", ou "desigual e combinado". Ao avançar esses argumentos, os teóricos da dependência buscavam confrontar as teses que entendiam as sociedades latino-americanas como sociedades "duais" - combinando setores capitalistas e não capitalistas - ou como resíduos das sociedades "feudais", situação que ainda seria superada por meio de uma revolução burguesa, ao estilo dos países europeus.
} 
desconhecimento das mesmas levou a interpretações confusas e superficiais sobre os temas discutidos e as teses propostas, encobrindo a riqueza do debate que se estabeleceu com o seu surgimento. Basicamente, podem distinguir-se duas vertentes: a "weberiana", que parte das teses cepalinas (embora busque subvertêlas), e que ganhou ampla projeção internacional; e a "marxista", que se inspira nas teses do imperialismo clássico, avançando uma crítica mais radical às noções desenvolvimentistas (Martins, 2006, 2012) ${ }^{6}$.

A versão "weberiana" da dependência encontra sua principal expressão no trabalho de Fernando Henrique Cardoso e Enzo Faletto: "Dependencia y Desarrollo em América Latina”, escrito entre os anos 1966 e 1967. Conforme Martins (2012), para esses autores, embora o capital estrangeiro tenha se constituído historicamente em um fator de descapitalização nas economias latinoamericanas - dificultando seu processo de desenvolvimento - era necessário diferenciar a antiga dominação imperialista (do início do século XX) da "nova dependência", estabelecida no novo cenário geopolítico e econômico após Segunda Guerra Mundial. No novo contexto, as formas de dominação política ganhavam maior autonomia, abrindo maior espaço para as negociações internacionais, ao passo que, o mercado interno das economias latino-americanas adquiria um maior dinamismo que provocava a contínua entrada de investimentos estrangeiros, compensando pelas tendências de descapitalização.

Quizá podría decirse que aquí ocurre lo contrario de lo que acontece en una economía de enclave; pues en tanto las decisiones de inversión dependen aunque parcialmente del mercado interno, el consumo es interno. Incluso, en los casos más típicos, se manifiesta una fuerte tendencia a la reinversión local, lo que, en cierto sentido, solidariza las intervenciones industriales extranjeras con la expansión económica del mercado interno (Cardoso e Faletto, 1977:58. Grifos nossos).

En efecto, los vínculos que ligan la situación de subdesarrollo al mercado internacional ya no aparecen aquí como directa y francamente políticos (como ocurre en las economías de enclave), ni son sólo el reflejo interno de decisiones tomadas en el mercado mundial (...). Por el contrario, parecería que la relación entre la economía nacional y los centros dinámicos de las economías centrales se establece en el mismo mercado interno. Sin embargo, en dos sentidos se mantienen las características de heteronomía: el desarrollo del sector industrial

\footnotetext{
${ }^{6}$ É preciso apontar que o presente trabalho não pretende esgotar as possibilidades de interpretação sobre os debates em torno da questão da dependência. Certamente, as convergências e divergências encontradas vão além da constituição de duas vertentes principais. Aqui, a contribuição de Martins (2006, 2012) é priorizada, pois, destaca o grupo de teorias e autores que constituem o marco teórico central deste trabalho. Para outras análises gerais a respeito dessas teorias, ver: Beigel (2006); Borón (2008); CLACSO (2006); Gwynne e Kay (2004); Santos (1998).
} 
continúa dependiendo de la "capacidad de importación" de bienes de capital y de materias primas complementarias para el nuevo tipo de diferenciación del sistema productivo (lo que lleva a lazos apretados de dependencia financiera), y además, esta forma de desarrollo supone la internacionalización de las condiciones del mercado interno. (Cardoso e Faletto, 1977:59. Grifos nossos) ${ }^{7}$.

No capitalismo dependente de Cardoso e Faletto, o desenvolvimento econômico era acompanhado (e alimentado) por uma contínua expansão do mercado interno. Essa situação levava as classes dominantes dos países dependentes a preferir uma associação com o capital estrangeiro (isto é, a optar pela dependência financeira e tecnológica), em lugar de buscar a autonomia plena. Para esses autores, de fato, a busca pela autonomia plena implicaria em um desgaste desnecessário, pois, resultaria em uma isolação política e em um consequente estancamento econômico - ao passo que, a opção pela dependência, abriria espaço para o desenvolvimento econômico, embora condicionado ${ }^{8}$. Nesse sentido, os autores propunham como modelo de desenvolvimento para os países da América Latina a "dependência negociada".

De acordo com Martins (2006; 2012), a superestimação do mercado interno dos países periféricos e do financiamento externo para a neutralização das saídas de capital, evidenciaram uma ambiguidade na construção teórica desses autores. Enquanto as contradições que caracterizam o ciclo de reprodução do capital - indicando a possibilidade de crises de acumulação - eram desconsideradas na elaboração do esquema da nova dependência, a existência de tais contratendências (e, portanto, das crises de acumulação) era admitida para o caso dos processos de acumulação nos países centrais - sendo o principal fator

\footnotetext{
${ }^{7}$ Essa compreensão da nova dependência como um processo de "internacionalização do mercado interno", será fortemente criticada pela vertente marxista, conforme a ser apresentado adiante.

${ }^{8}$ De acordo com Martins (2006:172), a partir de diversas influências teóricas (onde sobressai o instrumental weberiano), os autores construíram um verdadeiro "tipo ideal" da dependência. O conceito central desse esquema seria o de "estruturas de dominação", referente à configuração das relações político-sociais entre os grupos nacionais e estrangeiros envolvidos na dinâmica econômica dos países dependentes, que condicionaria a sua inserção no mercado internacional e as possibilidades de desenvolvimento. Assim, enquanto a instância política nacional possuía autonomia, era preciso escolher padrões de dominação que gravitavam, de um lado, entre o desenvolvimento e a dependência, e de outro, entre a autonomia ou estancamento. Dessa forma, Cardoso e Faletto conseguiam argumentar que "dependência e desenvolvimento" eram possíveis, contrapondo-se a visões mais radicais como a de A. G. Frank - um dos principais representantes da vertente marxista - que defendia a tese de que a dependência do sistema capitalista só podia resultar em uma estagnação econômica dos países periféricos. Assim também, no esquema de FHC e Faletto, o desenvolvimento do capitalismo nas sociedades periféricas parece não ter limites econômicos, apenas políticos.
} 
causal por trás do fenômeno da exportação de capitais para a região da América Latina. Assim:

Expansão e crise que compõem o ciclo são desarticuladas na análise de Cardoso e Faletto, em favor da primeira, para postular que, embora o capital estrangeiro lidere o processo de desenvolvimento dos países dependentes e os descapitalize, o seu dinamismo implica em sua contínua recapitalização (Martins, 2006:186).

Nesse sentido, Martins (2006; 2012) indica que o "desenvolvimentismo" se inseria nas entrelinhas da problemática teórica de Cardoso e Faletto, que teorizaram sobre a dependência no sentido de aceitá-la como padrão de desenvolvimento e dominação das sociedades latino-americanas. Por outro lado, a "vertente marxista" irá teorizar sobre a dependência com o intuito de superá-la, sendo esse ponto uma das principais divergências entre essas duas versões.

\subsection{1}

\section{A vertente marxista das teorias da dependência}

As contribuições da chamada "vertente marxista" das teorias da dependência ganharam notoriedade pela elaboração de críticas mais radicais a respeito da problemática do desenvolvimento dos países da América Latina, afastando-se das expectativas desenvolvimentistas e buscando ressaltar as contradições dos processos socioeconômicos em andamento ${ }^{9}$. Por outro lado, esses trabalhos também se destacaram por resgatar em suas elaborações as teorias e debates clássicos sobre o fenômeno do imperialismo ${ }^{10}$.

Na tradição Marxista, a teoria do imperialismo tem sido desenvolvida como o estudo do processo de expansão dos centros imperialistas e de sua dominação mundial. Na época do movimento revolucionário do Terceiro Mundo ${ }^{11}$, precisamos desenvolver uma teoria sobre as leis do desenvolvimento interno

\footnotetext{
9 Além de questionar as premissas do "nacional-desenvolvimentismo" latino-americano e da vertente "weberiana" da dependência, esses teóricos também questionaram o marxismo dos partidos comunistas da época, que também sofria limitações em função de sua abordagem baseada no nacionalismo metodológico e orientada para a modernização, entendendo o desenvolvimento em nível nacional, como um processo linear (Santos, 1998; Martins, 2006).

${ }^{10}$ Conforme Borón (2008:26), os teóricos latino-americanos da dependência (em geral) queriam estudar o fenômeno do imperialismo, porém, visto "desde baixo", isto é, a partir da perspectiva das nações submetidas ao seu domínio. Nesse sentido, pode-se dizer que os teóricos da denominada "vertente marxista" se distinguiram por reivindicar, de forma mais explicita, as contribuições das teorias clássicas sobre o imperialismo em seus estudos.

${ }^{11}$ A inclinação revolucionária que caracteriza a vertente marxista - i.e., de teorizar para superar as condições de subordinação e dependência - também encontrou inspiração nos acontecimentos revolucionários do período, como a Revolução Cubana e os processos de descolonização e independência na África, conforme evidencia o enunciado de Theotônio dos Santos.
} 
nesses países que são o objeto de tal expansão e são governados por ele. (...) $\mathrm{Na}$ análise do processo de constituição da economia mundial que integra as ditas 'economias nacionais' e um mercado mundial de commodities, capitais e inclusive, de força de trabalho, vemos que as relações produzidas por esse mercado são desiguais e combinadas - desiguais porque o desenvolvimento de partes do sistema acontece à custa de outras partes (Santos, 1970:231. Tradução própria. Grifos nossos).

Desse modo, a noção de que a expansão capitalista a nível mundial (ou, o imperialismo) engendra uma dinâmica de "desenvolvimento desigual"12 está fortemente embutida nas formulações teóricas dos intelectuais dessa versão da dependência que, a partir desse entendimento, orientaram seus esforços para o desvendamento e a compreensão das leis próprias do funcionamento do capitalismo no continente latino-americano.

Uma das contribuições mais notáveis dentro dessa corrente foi a de André Gunter Frank, intelectual que cunhou a frase "desenvolvimento do subdesenvolvimento", referindo-se à estreita e contraditória relação entre o desenvolvimento do sistema capitalista e a (re) produção de nações subdesenvolvidas. Em seu texto clássico de 1966 ("O desenvolvimento do subdesenvolvimento") - Frank apresentou as premissas básicas de sua tese, afirmando que a falta de desenvolvimento (ou o subdesenvolvimento) resultaria de uma dinâmica de relações desiguais, onde certas unidades (as metrópoles) teriam maior capacidade de apropriação dos excedentes gerados na economia mundial - seja através do comércio ou da circulação de capitais - conseguindo assim um maior grau de desenvolvimento, em detrimento do desenvolvimento das outras unidades (os satélites).

No esquema de Frank (1966), a noção do desenvolvimento desigual parece ser levada ao extremo, na medida em que o autor enfatiza a tendência de estagnação das economias periféricas - isto é, de (re) produção do subdesenvolvimento - que acontece por conta da dinâmica de apropriação desigual dos excedentes na economia mundial capitalista. A concepção de Frank foi criticada diversas vezes por esse motivo, sendo apontada como uma visão "simplista" e "mecânica" que, ao ressaltar os processos no nível sistêmico, não

\footnotetext{
${ }^{12}$ A questão do desenvolvimento desigual - que inspira a muitos desses teóricos - é enunciada por Lênin na Parte IV de sua obra "O imperialismo, fase superior do capitalismo", como segue: "O desenvolvimento da troca, tanto no interior como, em especial, no campo internacional, é um traço distintivo e característico do capitalismo. O desenvolvimento desigual, por saltos, das diferentes empresas e ramos da indústria e dos diferentes países é inevitável sob o capitalismo" (Lênin, 1916).
} 
deixava muito espaço para a análise de dinâmicas e situações específicas. De acordo com Martins (2006), faltou a essa contribuição uma visão do dinamismo das relações no interior do sistema, que formulasse uma teoria do capitalismo dependente.

A possibilidade de existir um processo de acumulação capitalista relativamente autônomo nas sociedades periféricas da economia mundial, começou então a ganhar maior consideração, inaugurando uma fase mais madura no desenvolvimento dessas teorias. Influenciados pelas contribuições de Frank e reafirmando o caráter descapitalizador do capital estrangeiro nos países dependentes, despontou uma nova geração de autores que se voltou à tarefa de:

(...) enraizar um marxismo renovado no continente. Se Lênin, Hilferding, Bukharin e Rosa Luxemburgo, partindo da teoria da acumulação de Marx, buscaram explicar a nova etapa do desenvolvimento capitalista no começo do século XX pensando a teoria do imperialismo, um novo desafio era posto para a geração reunida no $\mathrm{CESO}^{13}$. Na fase da integração dos sistemas de produção sob a égide da exportação de capitais, era uma exigência pensar como o capital submetia e subordinava as formações sociais dependentes - caso dos países latino-americanos - e como o imperialismo fincava raízes na região, investigando a maneira peculiar pela qual o capital se reproduz nas economias latinoamericanas, desde a sua vinculação ao mercado mundial (Ferreira e Luce, 2012:12. Grifos nossos).

E assim,

Embora se apoiem parcialmente nas reflexões de Baran e Frank, esses autores vão transcendê-las e construir um outro marco teórico. A apropriação da mais-valia e dos excedentes econômicos não impedia o progresso técnico e a industrialização nos países dependentes. Mas conferia ao desenvolvimento uma forma especifica que não o tornava capaz de eliminar a pobreza ou reduzi-la de forma sustentável (Martins, 2006:181. Grifos nossos).

Dentre os principais representantes dessa nova geração, figuram os intelectuais brasileiros Theotônio dos Santos, Vânia Bambirra e Ruy M. Marini. Basicamente, esses autores argumentavam que a expansão do capital estrangeiro nas economias periféricas correspondia a um processo de integração desigual e subordinado dos sistemas produtivos nacionais, que se colocavam como objeto da competição dos monopólios internacionais na busca pela manutenção de seu

13 O "Centro de Estudios Socio-económicos" (CESO) vinculado à Universidade do Chile, em Santiago, foi o lugar que abrigou a essa geração (pelo menos, até 1973) que, em sua maioria, estavam na condição de exilados de seus países. Nesse centro se reuniram autores como Theotônio dos Santos, Vânia Bambirra, A. G. Frank, Ruy M. Marini, Orlando Caputo, etc. 
dinamismo. Contestando as interpretações de FHC e Faletto, esses teóricos insistiam no caráter descapitalizador do capital estrangeiro, argumentando que, mais do que se guiarem por uma expansão dos mercados internos dos países periféricos, esses capitais estavam em busca da ampliação de suas bases de acumulação:

Essa entrada de capital estrangeiro na economia latino-americana, e particularmente no setor de manufaturas, é apresentada por alguns autores como um processo de internacionalização do mercado interno (...). O que realmente caracteriza o período do pós-guerra [à diferença do período entre guerras, quando a indústria latino-americana conseguiu, de fato, um peso importante no mercado interno de alguns países] é a reconquista desse mercado pelo capital estrangeiro, mas não apenas por meio do comércio, senão, sobretudo pela produção. Mais do que a internacionalização do mercado interno, trata-se da internacionalização (e a conseguinte desnacionalização) do sistema produtivo nacional, isto é, a sua integração à economia capitalista mundial (Marini, 1977:9-10. Tradução própria. Grifos nossos) $)^{14}$.

Por outro lado, os teóricos da vertente marxista - da mesma forma que FHC e Faletto - entendiam que os ajustes realizados nas estruturas produtivas nacionais não consistiam em um processo de subordinação automática, mas se estabelecia em função de uma associação entre forças externas e internas. A associação das classes dominantes dos países dependentes com o capital estrangeiro, e a consequente aceitação de sua posição inferior na economia mundial, era explicada pelo fato de que essa estratégia lhes permitia superar os limites endógenos de sua capacidade de acumulação - levando-os a assumir uma posição monopólica no âmbito de seus segmentos produtivos de atuação e de seus Estados nacionais.

Para os dependentistas marxistas, as classes dominantes da periferia inseridas nessa aliança encontravam-se, contudo, em uma situação de desvantagem - provocada pela dependência financeira e tecnológica, que resultava em uma contínua de transferência de valores para o exterior. A fim de permitir os aspectos desvantajosos dessa relação e conseguir avançar um processo de acumulação relativamente autônomo, essas classes precisavam perseguir "superlucros" que compensassem pelas perdas de valor, não no sentido de aumentar o progresso técnico, mas de "superexplorar" a força de trabalho.

\footnotetext{
${ }^{14}$ Em consonância com FHC e Faletto, porém, Marini (1977) ressaltou que essa nova forma de integração dos sistemas produtivos (via "desnacionalização") seria diferente do "enclave", formato típico do final do século XIX e início do século XX. Já um exemplo mais atual da lógica do enclave, para Marini, seriam os investimentos realizados sob a modalidade de "maquila".
} 
A "superexploração da força de trabalho" constitui uma categoria central do capitalismo dependente, conforme teorizado pelos intelectuais citados anteriormente. A superexploração da força de trabalho representa, acima de tudo, o mecanismo ao qual as classes dominantes dos países dependentes recorrem para contrarrestar os efeitos da transferência de valores para os países centrais (resultante de sua condição de dependência), possibilitando, assim, o desdobramento de uma dinâmica de acumulação relativamente autônoma em seus territórios $^{15}$.

Considerando as implicações desse mecanismo em termos de uma corrosão dos salários, do desgaste físico dos trabalhadores, e da diminuição das oportunidades de emprego, a superexploração serviu também para explicar a incapacidade do desenvolvimento econômico nas sociedades dependentes em eliminar ou reduzir os problemas de pobreza e exclusão social. Nesse sentido, o fenômeno da superexploração se colocou também como mais um argumento avançado pelos autores da vertente marxista da dependência em contra da premissa de uma expansão contínua da demanda interna nos países dependentes aspecto que, de acordo com os teóricos da vertente weberiana, sustentaria o desenvolvimento capitalista e a entrada de capitais estrangeiros nesses países.

Ao analisar o ciclo completo de acumulação do capital nas economias periféricas - que era atravessado pela dinâmica da superexploração e por uma concomitante contração do consumo interno - os dependentistas marxistas, diferentemente das explicações de Cardoso e Faletto, reconheceram e enfatizaram a possibilidade do surgimento de crises de acumulação nas economias dependentes. Nesse contexto, os autores identificaram uma "cisão" entre a fase da produção e a fase da circulação, onde a produção realizada internamente não encontrava espaço suficiente para se realizar, devendo procurar outros mercados no exterior. Conforme será visto posteriormente, essa situação resultou na colocação em marcha de outro fenômeno específico das economias dependentes: o do "subimperialismo", que foi teorizado, principalmente, por Ruy M. Marini.

Assim, a cisão identificada por esses autores, se colocava como mais uma prova de que as mudanças nas estruturas produtivas das economias dependentes -

\footnotetext{
${ }^{15}$ Já as formas que esse mecanismo pode adotar são: pelo aumento da intensidade do trabalho ou da prolongação da jornada de trabalho (sem um aumento equivalente na remuneração); e pela diminuição direta dos salários, reduzindo a capacidade de consumo do trabalhador além de seu limite normal (Marini, 1973).
} 
impulsionadas pela crescente entrada de capital estrangeiro - se orientavam, primeiramente, ao atendimento das necessidades de acumulação dos monopólios internacionais, em lugar das necessidades de consumo e sobrevivência das populações locais. Em outras palavras, o principal objetivo dos investimentos estrangeiros no desenvolvimento das indústrias periféricas, não era o de abastecer a demanda do mercado interno, mas ampliar as bases de sua acumulação finalidade obtida pelo controle desses mercados e, principalmente, pelo aproveitamento da mão de obra e dos recursos naturais mais baratos ofertados pelas economias periféricas.

Nesse quadro, a grande contradição das economias capitalistas dependentes consistia em que, para continuar a atrair os fluxos de capitais estrangeiros e impulsionar seu processo semi-autônomo de acumulação e desenvolvimento econômico, essa cisão precisava ser continuamente aprofundada - ou seja, as classes dominantes deviam recorrer continuamente aos mecanismos de superexploração da força de trabalho - levando à constante reprodução das marcas do subdesenvolvimento. Sendo assim, para os autores da denominada corrente marxista da dependência, a superação da condição de dependência passava por uma ruptura com o sistema capitalista.

\section{2 \\ As teorias da dependência na era da globalização}

A influência das teorias da dependência nos debates sobre o desenvolvimento econômico dos países da América Latina perdeu força a partir de meados da década de 1980, e ao longo da década de 1990, em função da nova conjuntura instalada: de um lado, a profunda crise econômica que passou a afetar os países latino-americanos, provocada pelo peso da dívida externa, que se colocou como uma restrição para a margem de ação dos governos nacionais; e por outro lado, a colocação em marcha de um processo de reestruturação econômica e política a nível mundial, marcado pela disseminação do neoliberalismo e pela consolidação da hegemonia estadunidense, com o fim da Guerra Fria.

O modelo econômico neoliberal, que na América Latina se difundiu com maior intensidade ao longo da década de 1990, pregava a liberalização econômica por meio da eliminação das barreiras à circulação dos fluxos comerciais e de 
capitais, e de um maior "afastamento" dos Estados na condução das atividades econômicas. Mais do que uma conquista no meio econômico, a ofensiva neoliberal encontrou seu maior êxito nos âmbitos político e cultural, conseguindo uma ampla aceitação das ideias sobre a chegada de uma nova era em que os estados nacionais e as fronteiras perderiam relevância perante a consolidação de uma economia global (Beigel, 2006; Brieger, 2002). Além disso, o paradigma neoliberal restaurou a promessa do desenvolvimento, processo que estaria ao alcance de todas as nações uma vez adotadas as recomendações de seu receituário político e econômico.

De acordo com Beigel (2006), nesse contexto, as sociedades latinoamericanas - assombradas pelos fantasmas do passado autoritário e da espiral inflacionária que acompanhou a crise dos anos 1980 - pareciam conformar-se com a busca da estabilidade econômica e da convivência democrática, relegando as preocupações com a mudança estrutural ou com a procura de uma maior autonomia política e econômica, para um segundo plano.

Além das mudanças na conjuntura política e econômica, o resfriamento das teorias da dependência foi nutrido por fatores oriundos do próprio campo intelectual. De um lado, pelas diversas críticas que foram avançadas desqualificando essas teorias de forma generalizada, taxando-as como "mecânicas" ou "simplistas"16. Por outro lado, o desenvolvimento das teorias da dependência - especialmente, da vertente marxista ${ }^{17}$ - foi truncado pelos diversos episódios de censura, que resultaram na interrupção das atividades dos grupos de pesquisa sobre o tema (em função do exílio dos seus principais intelectuais), deixando muitos trabalhos abandonados e não publicados.

\footnotetext{
${ }^{16}$ De acordo com Beigel (2006:305), chamá-las de "simplistas" era também uma forma de taxá-las como "ideológicas", alimentando o descrédito sobre a qualidade teórica das mesmas.

${ }^{17}$ Os principais proponentes dessa vertente passaram por diversas situações de exílio a partir da onda de governos militares que se instalaram na região entre os anos 1960 e 1980. Até hoje, as obras de importantes autores brasileiros como Theotônio Do Santos, Vânia Bambirra e Ruy M. Marini, por exemplo, permanecem amplamente desconhecidas no Brasil, pois nunca foram publicadas no país ou traduzidas ao português. Aos poucos, porém, essa situação está mudando em função de diversos esforços que buscam resgatar essas contribuições. No Brasil, pode destacar-se o trabalho do Instituto de Estudos Latino-Americanos (IELA) da Universidade Federal de Santa Catarina (UFSC), responsável pela edição da coleção "Pátria Grande. Biblioteca do Pensamento Crítico Latino-Americano", iniciativa que busca divulgar obras clássicas das ciências sociais latino-americanas, em geral, pouco (ou nada) conhecidas no país. Também, pode mencionar-se o trabalho de grupos de pesquisa como: o Grupo de Trabalho da Teoria Marxista da Dependência (GT-TMD), vinculado à Sociedade Brasileira de Economia Política (SEP), e o Núcleo de História Econômica da Dependência Latino-Americana (HEDLA-UFRGS), que promovem investigações e debates sobre a questão da dependência, além da recuperação, disseminação e acesso à bibliografia clássica e atual sobre o tema.
} 
Recentemente, contudo, tem se verificado um amplo resgate das premissas avançadas pelos dependentistas, especialmente, em função das insuficiências demonstradas pelo modelo neoliberal para lidar com as necessidades e os problemas do desenvolvimento socioeconômico dos países da região (Borón, 2008; Kay, 2009). As expectativas de harmonização e convergência pregadas pelo paradigma da globalização passaram a ser contestadas pelo agravamento das desigualdades socioeconômicas em nível mundial. Assim, muitas das condições que circunscreveram a emergência do debate a respeito do desenvolvimento das sociedades latino-americanas e da sua vinculação à economia mundial nas décadas de 50, 60 e 70, verificam-se atualmente (inclusive, em níveis mais acirrados).

(...) as teorias estruturalistas e a teoria da dependência latino-americanas apresentam uma relevância ainda maior agora, em uma fase em que as forças que se ocultam atrás do capitalismo global são ainda menos retraídas do que no passado, comparado com o período em que essas teorias foram originariamente formuladas, ou seja, na época da industrialização por substituição de importações e do capitalismo de Estado. Porém, paradoxalmente, as teorias estruturalistas e da dependência são raramente visualizadas hoje. Isso parece surpreendente, já que elas observaram os problemas do subdesenvolvimento e do desenvolvimento dentro de um contexto global (Kay, 2009:362-363).

Em meio a um contexto de predomínio dos paradigmas "universalizantes", que ocultam as assimetrias dos processos políticos, sociais e econômicos globais, atribuindo-lhes um caráter impessoal, a recuperação geral do pensamento social latino-americano - particularmente, das teorias estruturalistas e da dependência, que ganharam destaque pela sua abordagem holística e histórica da realidade - se apresenta como um esforço de reflexão crítica sobre a ordem política e econômica contemporânea, ajudando a lançar luz sobre problemáticas e fenômenos atuais como:

a) a globalização e a crescente assimetria no mundo, isto é, sobre a dupla dinâmica de aprofundamento da integração dos mercados nacionais (de produção e de consumo) em nível mundial e da persistência (ou emergência de novos) padrões de estratificação entre os países e no interior dos mesmos - com destaque para as tendências de aprofundamento das desigualdades entre as economias consideradas "em desenvolvimento" ou "periféricas", (no caso, entre os próprios países da América Latina), e o fenômeno das economias "emergentes" (por exemplo, do grupo dos BRICS); 
b) o papel do Estado nos processos econômicos, que havia sido relegado para um segundo plano pelas correntes neoliberais, mas que assume, de fato, um papel decisivo na coordenação das novas condições de competitividade na economia mundial. Nesse contexto, a atuação dos Estados nas economias dependentes que conseguem um maior desenvolvimento relativo (como é a situação dos países emergentes), tem chamado maior atenção;

c) a vulnerabilidade e dependência financeira, que cresceram com o aumento da mobilidade do capital internacional, e em função do persistente fracasso das economias dependentes em expandir suas poupanças nacionais de forma autônoma;

d) o intercâmbio desigual e a persistência de uma dinâmica de apropriação desigual dos excedentes gerados nas economias periféricas, que continuam a transferir uma parte importante desses ganhos para os países centrais, através de diferentes mecanismos (pelo comércio de bens, remessas de lucros; pagamento de royalties, pagamento de juros, etc.);

e) a dependência tecnológica, que diz respeito à baixa difusão tecnológica nos países em desenvolvimento, apesar do aumento dos investimentos estrangeiros e da crescente instalação de empresas multinacionais em seus territórios. Também ao fato que os países centrais continuam a controlar a maior parte dos investimentos (e das atividades) em pesquisa e desenvolvimento de novas capacidades tecnológicas ${ }^{18}$.

\subsection{1 \\ Neoliberalismo vs. Neodesenvolvimentismo vs. Dependência}

Desde o início dos anos 2000, a necessidade de contornar as ineficiências do modelo econômico neoliberal e de avançar análises mais críticas a respeito dos processos econômicos contemporâneos, abriu espaço para o surgimento de novas agendas políticas e acadêmicas, e para a restauração de antigos debates a respeito das especificidades do desenvolvimento dos países da América Latina e do caráter de sua inserção na economia mundial.

\footnotetext{
${ }^{18}$ Esses pontos, enumerados por Kay (2009) e Gwynne e Kay (2004), se colocam entre os principais temas tratados nos debates atuais em torno do desenvolvimento dos países latinoamericanos na nova conjuntura econômica mundial.
} 
Em primeiro lugar, destaca-se a agenda "neodesenvolvimentista" (ou "neoestruturalista"), que resgata vários dos pressupostos do "nacionaldesenvolvimentismo" (ou do "estruturalismo latino-americano") dos anos 1960 promovidos pela CEPAL. Basicamente, essa corrente parte do reconhecimento de que na atual fase de globalização as assimetrias entre os países centrais e os países periféricos continuam a se aprofundar - e não a diminuir, como afirmava o paradigma neoliberal - e se orienta para a busca de medidas que corrijam essas desigualdades e melhorem o posicionamento das economias latino-americanas na economia mundial. À diferença da proposta neoliberal, o neodesenvolvimentismo defende uma maior intervenção dos Estados como intermediários dos processos socioeconômicos e também assume um maior compromisso com a resolução das problemáticas sociais (como a desigualdade social e a pobreza), que devem ser contempladas em conjunto com os objetivos de estabilidade macroeconômica ${ }^{19}$.

Embora o neodesenvolvimentismo desenhe as suas recomendações políticas e econômicas levando em consideração as particularidades históricas e estruturais dos países latino-americanos, ele não rompe radicalmente com as diretrizes do modelo neoliberal, no sentido de que, também entende que as oportunidades para conseguir dinamizar a economia nacional advêm de uma maior integração com os mercados mundiais. Frequentemente, os debates em torno do neodesenvolvimentismo se voltam para essa questão, discutindo até que ponto essa proposta, que emerge com força no início do século XXI, se coloca como uma alternativa ao modelo neoliberal.

Outra vertente teórica que parece ter se fundido com as premissas neoliberais, decretando a sua própria morte, foi a versão "weberiana" da dependência. Isso se constata ao analisar as experiências de seu principal expoente, o Fernando H. Cardoso, como presidente da República do Brasil no período de auge do neoliberalismo (1995-2002). De acordo com Kay (2009), muitos analistas apontam que Cardoso abraçou o neoliberalismo e a globalização, pois, ao longo de seu governo, promoveu uma profunda desnacionalização da economia brasileira, incentivando a entrada de capitais estrangeiros e a instalação

\footnotetext{
${ }^{19}$ Embora se defenda uma maior intervenção do Estado, isso não se refere a uma participação direta e centralizadora como acontecia na época da "substituição de importações". Com relação às políticas sociais, as mesmas são concebidas de forma estratégica, isto é, são pensadas dentro de uma lógica de inserção social que permita alavancar o potencial socioeconômico da população (seja como consumidores ou como trabalhadores), buscando escapar ao mero assistencialismo (Boschi e Gaitán, 2008).
} 
de corporações transnacionais no país. Embora tivesse insistido diversas vezes de que não era um neoliberal, FHC chegou a admitir, de fato, que as suas visões tinham mudado:

\begin{abstract}
Quando eu escrevi meus livros sobre a teoria da dependência, a hipótese subjacente era que o processo internacional do capitalismo afetava adversamente as condições do desenvolvimento. Ele não impedia o desenvolvimento, mas o tornava desequilibrado e injusto. Muitos consideravam que a economia voltada para dentro era a forma possível de defesa contra a alternativa de uma integração internacional, vista como arriscada e perigosa. Essa visão mudou. Temos de admitir que a participação na economia global pode ser positiva, que o sistema internacional não é necessariamente hostil. Mas devemos trabalhar cuidadosamente para agarrar as oportunidades. (Cardoso, 2001:284 apud Kay, 2009:378).
\end{abstract}

Pode-se dizer que o novo posicionamento de FHC, no fundo, permanecia fiel à noção de "dependência negociada" - isto é, da busca por uma adaptação às condições da economia mundial, perante a inevitabilidade da dependência - que havia sido proposta pelo autor no passado. A diferença estaria na renúncia ao uso do termo "dependência", uma vez que a sua formulação se assentava na hipótese "ultrapassada" de que a participação na economia mundial só podia ter consequências negativas.

Por fim, a vertente marxista da teoria da dependência também ressurge no debate público e acadêmico atual, fazendo parte dos esforços de elaboração de análises mais críticas a respeito dos padrões atuais de desenvolvimento dos países do continente. Sem abrir mão do termo "dependência" e reivindicando as suas raízes teóricas, as discussões atuais também se inserem no conjunto das reflexões sobre o fenômeno contemporâneo do imperialismo - isto é, da expansão mundial do capitalismo - reflexões que deixaram de ser "eurocêntricas", sendo cada vez mais sensíveis a variações regionais e nacionais (Borón, 2008).

Nesse contexto de renovação dos debates da vertente marxista da dependência, podem destacar-se dois pontos centrais de discussão: (a) primeiro, o debate a respeito das mudanças na economia mundial, na divisão internacional do trabalho e dos novos formatos das relações de dependência na América Latina; (b) e segundo, o debate em torno da especificidade da dependência e do aspecto central que a define, isto é, a superexploração da força de trabalho.

As mudanças na economia mundial e suas repercussões nas relações de dependência no novo século constituem um dos pontos mais relevantes da 
discussão atual. A esse respeito, os debates buscam dar explicações para tendências como a "desindustrialização" de muitas das economias latinoamericanas, e o retorno para a função de fornecedores de matérias primas - isto é, ao padrão de desenvolvimento primário-exportador. Enquanto algumas abordagens parecem entender esses processos como sinais de um "retrocesso" no caminho ao desenvolvimento pleno (que precisa ser corrigido), os teóricos da que, atualmente, também se faz chamar "Teoria Marxista da Dependência" - ou, simplesmente, TMD - coincidem em afirmar que essas tendências se referem, na verdade, às novas manifestações da expansão da economia capitalista na região. Assim, ao analisar os novos fenômenos econômicos, os teóricos da TMD instam a não confundir a "essência" dos processos com as suas expressões mais concretas.

Nesse sentido, por exemplo, o deslocamento dos capitais industriais para outras áreas do sistema mundial - resultando na tal "desindustrialização" das economias latino-americanas e no surgimento de "novas periferias" (especificamente, nas antigas repúblicas soviéticas do leste europeu) - indica que o capital continua na busca pela ampliação de suas bases de acumulação (processo que foi potencializado pela difusão da globalização neoliberal). Ao mesmo tempo, essa nova ampliação resulta no acirramento da competição entre as economias periféricas para a atração desses fluxos de capitais, constrangendo-as a reforçar os mecanismos para a maior liberalização da economia e disponibilização de mão de obra e recursos naturais mais baratos (Sotelo Valencia, 2009) ${ }^{20}$.

Em outras palavras, a lógica por trás da expansão do capital (i.e., a sua essência) - de assegurar a sua contínua reprodução explorando (e reforçando) as assimetrias do sistema econômico mundial - se mantém, mas mudam às suas formas. Ou seja, a divisão internacional do trabalho passa por uma reestruturação, devendo ser entendida, conforme explica Osório (2012:77), como um esquema que vai além da simples divisão de tarefas:

\footnotetext{
${ }^{20}$ Embora Sotelo Valencia (2009) confirme que há um reforço da condição de dependência dos países latino-americanos, a partir das reestruturações recentes da economia mundial, o autor também aponta que há um processo paralelo de "generalização" do fenômeno da superexploração do trabalho, gerando uma contradição em seu argumento. Ao falar um processo de "generalização da superexploração" no mundo, não haveria mais sentido falar em dependência ou em seu reforço - isto é, na existência de processo específico de acumulação do capital, correspondente às economias periféricas (dependentes). Todavia, conforme explica Carcanholo (2013), essa contradição parece advir de um entendimento equívoco da superexploração do trabalho como categoria analítica e como fenômeno. Essa discussão em torno da especificidade da superexploração do trabalho e da dependência é apresentada a seguir.
} 
A monopolização de determinadas linhas de produção (e a produção, por conseguinte, de determinados valores de uso) pelas regiões centrais caminha de mãos dadas com a concorrência que se produz no mundo dependente em torno de linhas de produção de bens, sejam primários, secundários ou terciários. Isso coloca em evidencia que a DIT não é somente uma distribuição de funções diferenciadas no nível do sistema mundial, em matéria de valores de uso, mas tem também implicações no campo do valor enquanto tal. Manter prerrogativas monopolistas sobre determinados bens ou conhecimentos tem implicações na capacidade apropriação do valor. (Grifos nossos).

Para os teóricos da TMD, a compreensão dos novos padrões de desenvolvimento dos países latino-americanos deve considerar então não apenas $o$ que está sendo produzido na economia, mas também o seu lugar na estrutura de repartição do valor da economia mundial ${ }^{21}$. Dessa forma, tem-se que, no advento do novo século, a maior parte das economias latino-americanas mudou o seu padrão (isto é, a forma) de desenvolvimento e inserção internacional, ao mesmo tempo em que experimentam um reforço de sua condição de dependência. $\mathrm{O}$ capitalismo, com todas as suas particularidades, continua a reproduzir-se nos países da região, sendo, portanto, complicado falar em um retrocesso desse desenvolvimento (como parece implicar a noção de "desindustrialização") ou em uma perda de relevância das relações de dependência.

Outro ponto central nos debates atuais da corrente marxista da dependência, diz respeito ao questionamento sobre a especificidade da dependência e do fenômeno da superexploração da força de trabalho, questionamento que é colocado ao verificar-se que, ao redor do mundo - isto é, tanto nos países periféricos como nos países centrais - tem havido uma

\footnotetext{
${ }^{21}$ Para fazer esse tipo de análise, Osório (2012:40-41) propõe utilizar a noção de "padrão de reprodução do capital", que serve como uma categoria "intermediária" - isto é, que busca mediar os níveis mais gerais e abstratos de análise (como "modo de produção do capital" e "sistema capitalista mundial") e os níveis menos abstratos e mais concretos (como "formação econômicosocial" e "conjuntura") - para dar conta das "formas como o capital se reproduz em períodos históricos específicos e em espaços geoterritoriais determinados, considerando as características de sua metamorfose na passagem pelas esferas da produção e da circulação (...), integrando o processo de valorização e sua encarnação em valores de uso específicos (calças, rádios, celulares, tanques de guerra), assim como as contradições que esses processos geram". Essa categoria representa o esforço concreto do autor em distinguir a "essência" de suas "formas de expressão" mais concretas e contingentes. Diz respeito, também, a uma categoria previamente desenvolvida por Ruy M. Marini, autor que se destacou por problematizar a respeito da complexidade da DIT, quando buscava entender por que diversos países da América Latina estavam se industrializando entre as décadas de 1950 e 1970. Considerando a especificidade histórica da América Latina, Osório (2012:78) distingue então três padrões de reprodução do capital que se tornaram dominantes por certos períodos: o padrão "agromineiro exportador" (até a segunda metade do século XX); o padrão industrial que, por sua vez, se divide em duas etapas: a internalizada e autônoma (da segunda metade dos anos 1930 até os anos 1940), e a etapa de integração ao capital estrangeiro (desde os anos 1950 até meados dos anos 1970); e, finalmente, o padrão "exportador de especialização produtiva" (desde meados dos anos 1980 até o presente).
} 
proliferação de violações (ou perda) dos direitos dos trabalhadores, levando muitos a argumentar sobre uma "generalização" da superexploração. Tal argumento implicaria em dizer que dependência deixou de ser uma condição específica.

Entretanto, autores como Carcanholo (2013) e Luce (2013b), defendem que esse tipo de conclusão deriva de um mau entendimento do significado da superexploração da força de trabalho, que não é a mesma coisa que o aumento da taxa de exploração, nem é igual às formas pela qual se manifesta (por meio do aumento da jornada de trabalho ou diminuição dos salários). De acordo com Carcanholo (2013), embora se expressem de formas parecidas, o aumento da exploração da força de trabalho é diferente da superexploração entendida como categoria - isto é, como o mecanismo ao qual recorrem as classes dominantes dos países dependentes para contrarrestar os efeitos da transferência de capital aos países centrais. Por outro lado, se esses argumentos realmente se referem a uma generalização da superexploração da força de trabalho (no seu significado como categoria), então não faria mais sentido falar sobre o fenômeno da dependência ou continuar elaborando uma teoria específica do capitalismo dependente, o que seria complicado, considerando as condições atuais de exacerbação das assimetrias na economia mundial.

\section{3 \\ Nuances no esquema da dependência: a emergência do subimperialismo}

No âmbito dos debates em torno das especificidades do capitalismo dependente - no caso, latino-americano - impulsionado pelos dependentistas de afiliação marxista, o autor Ruy M. Marini identificou a emergência do fenômeno do "subimperialismo", referente a uma nova fase no desenvolvimento do capitalismo dependente, que se manifestaria nos países que conseguiram atingir um maior desenvolvimento relativo de seus sistemas produtivos particularmente, no Brasil, que constitui a principal referência das premissas do autor. Essa contribuição é destacada neste capítulo, pois, além fornecer mais elementos para a compreensão do processo de acumulação capitalista nos países dependentes, coloca em evidência dinâmicas de diferenciação entre as próprias 
nações dependentes (sobretudo, entre o Brasil e seus países vizinhos) - lançando luz sobre o caso estudado no presente trabalho.

O surgimento do fenômeno do subimperialismo se radica no contexto de expansão do sistema capitalista após a II Guerra Mundial que, de acordo com Marini (1977:3), se orientou para uma ampliação das bases de acumulação dos monopólios internacionais, por meio de uma crescente integração e controle dos sistemas produtivos nacionais, caracterizando o período como o da "integração imperialista dos sistemas de produção”. Na maior parte dos países latinoamericanos, a forte entrada de capital estrangeiro - de origem estadunidense, principalmente - ao longo das décadas de 1960 e 1970, se traduziu em um crescimento significativo da atividade industrial manufatureira. De acordo com Marini (1976, 1977), essa dinâmica estava provocando o surgimento de "centros médios de acumulação", que passavam a desafiar o modelo tradicional de divisão internacional do trabalho, caracterizado pela divisão centro-periferia e pelo intercâmbio de manufaturas (produzidas no centro) por alimentos e matérias primas (produzidas na periferia).

Passou o tempo do modelo simples centro-periferia, caracterizado pelo intercâmbio de manufaturas por alimentos e matérias primas. Encontramo-nos perante uma nova realidade econômica na qual a indústria assume um papel cada vez mais decisivo. Isto é verdade mesmo quando o capital industrial se amplia e se fortalece em áreas extrativas e agrícolas (...). O resultado foi um reescalonamento, uma hierarquização dos países capitalistas em forma piramidal, e, por conseguinte, o surgimento de centros médios de acumulação - que são também potências capitalistas médias - o que nos tem levado a falar da emergência de um subimperialismo (Marini, 1977:8. Tradução própria) ${ }^{22}$.

O autor identificou o surgimento do subimperialismo partindo da análise no nível do sistema capitalista, localizando-o no contexto da inauguração de uma nova fase de expansão do capitalismo a nível mundial. Dessa forma, Marini estabelecia um estreito diálogo com as teorias clássicas sobre o fenômeno do

\footnotetext{
${ }^{22}$ A emergência desses centros médios, contudo, não significava em uma ruptura com a lógica de subordinação desses países à economia mundial, pois esse fenômeno resultava de um processo de integração impulsionado pelo capital internacional, tendo como contrapartida uma "desnacionalização" dos sistemas produtivos nacionais. Ou seja, tratava-se de um processo de integração e crescimento econômico subordinado e marcado por contradições. Essa questão é reforçada por Marini (1976:40) ao afirmar que, o que se observava correspondia ao: “(...) surgimento de uma nova divisão internacional do trabalho, que transfere - desigualmente, vale lembrar - etapas da produção industrial aos países dependentes, enquanto os países avançados se especializam nas etapas superiores; simultaneamente, aperfeiçoam-se os mecanismos de controle financeiro e tecnológico dos países avançados sobre o conjunto do sistema" (Grifos nossos).
} 
imperialismo. De fato, Marini (1976:37) afirmou que a teoria leninista do imperialismo era um ponto de referencia obrigatório para o estudo do subimperialismo $^{23}$. Seguindo esse corpo teórico, o autor definiu o subimperialismo como "a forma que assume a economia dependente ao chegar à etapa dos monopólios e do capital financeiro" (Marini, 1977:17). Todavia, apesar de que ambos os fenômenos (o imperialismo e o subimperialismo) compartilhavam a mesma raiz - na tendência expansionista do capitalismo a nível mundial - o subimperialismo assumia um caráter específico, que derivava das particularidades do ciclo de acumulação de capital nas economias dependentes.

Conforme apresentado anteriormente, os teóricos da vertente marxista da dependência (e Marini, particularmente) argumentavam que o desdobramento do processo de acumulação capitalista nas economias dependentes era possível em função da "superexploração da força de trabalho", mecanismo que funcionava como medida para compensar as perdas provocadas pela dinâmica de transferência de valor às economias centrais. A superexploração da força de trabalho resultava, por sua vez, em uma tendência de compressão do consumo popular (isto é, de retração do mercado interno), acirrando as tendências de centralização e concentração que acompanham a dinâmica de acumulação do capital. Nesse contexto, Marini (1976) apontava para uma cisão entre a estrutura produtiva nacional e as necessidades de consumo das amplas massas, na medida em que diversos setores industriais - principalmente, os que eram controlados

\footnotetext{
${ }^{23}$ Além de Lênin, Marini também cita a importância das contribuições de outros autores como Bukharin e Hilferding. Em um trabalho de tese doutoral sobre a história da categoria do subimperialismo formulada por Marini, Luce (2011) dedica um capítulo a analisar as ligações entre a tese do subimperialismo e as teorias do imperialismo, apontando para o que havia de específico na primeira com relação às segundas. Em primeiro lugar, destaca a própria definição do fenômeno, que segue a caracterização do imperialismo dominante proposta por Lênin - como uma nova fase do desenvolvimento do capitalismo, marcado pela formação de monopólios e aumento do capital financeiro. Conforme explica Luce (2011), a diferença crucial entre ambos os fenômenos derivará do fato que, um se desdobra nas economias dominantes, e o outro nas economias dependentes. Outro aspecto ressaltado é a discussão sobre o papel dos Estados dependentes nesse processo, onde Marini se utilizou das reflexões de Bukharin a respeito da ideia de "aglomeração do capital com o Estado nacional" no contexto do imperialismo - isto é, do papel central que os Estados assumiam nos processos monopolização e internacionalização do capital. Nas economias subimperialistas, Marini identificou que o Estado, além de reforçar seu papel no sentido de assegurar o processo de integração dos sistemas produtivos nacionais à dinâmica econômica mundial e a reprodução do capital em seu território, adotaria também uma segunda função que seria a de agir procurando uma posição de "autonomia relativa", no sentido de melhorar a condição das burguesias locais perante o capital internacional. Em seu estudo, Luce (2011) ressalta a importância dessa reflexão na formulação de Marini, na medida em que o autor procurava mostrar que não se tratava de um processo "mecanicista" de submissão automática do Estado dependente ao capital internacional, levando-o a propor a noção de "cooperação antagônica" para descrever essa dinâmica.
} 
pelo capital internacional - passavam cada vez mais a orientar sua produção para as esferas altas do consumo (no mercado interno) ou para o mercado mundial. Assim, a superexploração da força de trabalho e a cisão entre as esferas alta e baixa de consumo se colocavam na base das contratendências à acumulação no capitalismo dependente, marcando também as suas crises.

O subimperialismo também implicava na entrada à etapa de exportação de capital e de apropriação de matérias primas e fontes de energia no exterior. Enquanto no imperialismo essas medidas constituíam, essencialmente, uma saída para a tendência de queda da rentabilidade do capital, no subimperialismo serviam também para conter as contratendências particulares do capitalismo dependente (indicadas acima). No caso, Marini destacava o problema de "realização" do consumo nas economias dependentes, originados em função das restrições impostas ao mercado interno ${ }^{24}$.

Por outro lado, na medida em que promovia uma expansão externa, buscando extrair benefícios das relações desiguais com seu entorno (principalmente, com as nações mais débeis economicamente), o subimperialismo consistia também na configuração de uma hegemonia regional, isto é, na conquista de uma esfera de influência própria e no estabelecimento de uma divisão desigual do trabalho organizada em seu proveito. A economia subimperialista avançava no estabelecimento dessa estrutura desigual pelos mesmos mecanismos empregados pelo imperialismo, ou seja: pelo controle de matéria prima e fontes de energia no exterior (reduzindo o custo operacional de suas indústrias); pela exportação de manufaturados (tornando os países vizinhos em mercados consumidores dos bens produzidos na economia subimperialista, e consolidando um padrão de "intercâmbio desigual" com os mesmos) ${ }^{25}$; e pelas

\footnotetext{
${ }^{24}$ A ênfase no problema da "realização" lhe renderam críticas de "subconsumista". Mas, conforme explica Luce (2011), Marini não ignorava a tendência de queda da taxa de lucro; ele apenas buscava ressaltar o que havia de específico no ciclo de acumulação do capitalismo dependente, no caso, uma crise de realização nutrida pelas tendências da superexploração da força de trabalho e da cisão entre as esferas da produção e do consumo.

${ }^{25}$ Luce (2011) explica que, para Marini, a exportação de manufaturados constituía a principal expressão da diferenciação econômica das nações subimperialistas, isto é, a forma pela qual se podia inferir, mais claramente, o seu maior poder (econômico) relativo - diferentemente das economias imperialistas, cujo predomínio se fazia mais notável na extensa presença de suas corporações nos diferentes ramos da produção. Isso não significava dizer que os demais mecanismos estavam ausentes ou eram menos importantes. A argumentação de Marini reflete, apenas, as particularidades do momento histórico analisado por ele. Já, ao considerar as manifestações atuais do fenômeno do subimperialismo brasileiro, autores como Luce (2011; 2013a) e Bueno e Seabra (2009) identificam a prevalência de outros mecanismos.
} 
exportações de capitais. Todavia, diferentemente do que era possível no imperialismo, Marini entendia que, a apropriação de valor das sociedades dependentes mais débeis pela economia subimperialista, não poderia resultar em uma elevação do nível geral de vida de sua população. Tendo como referência central o caso do Brasil, o autor argumentou que:

O capitalismo brasileiro orientou-se, assim, em direção a um desenvolvimento monstruoso, posto que chega à etapa imperialista antes de haver logrado a mudança global da economia nacional e em uma situação de dependência crescente frente ao imperialismo internacional. A consequência mais importante deste fato é que, ao contrário do que acontece com as economias capitalistas centrais, o subimperialismo brasileiro não pode converter a espoliação que pretende realizar no exterior em um fator de elevação do nível de vida interno, capaz de amortecer o ímpeto da luta de classes; tem, ao contrário, pela necessidade que experimenta de proporcionar um superlucro a seu sócio maior norte-americano, que agravar violentamente a exploração do trabalho no marco da economia nacional, no esforço para reduzir seus custos de produção (Marini, 1974:101 apud Luce, 2011:98).

Dessa forma, tem-se que, a ascensão da economia subimperialista marcava não apenas uma alteração na estrutura tradicional da divisão internacional do trabalho, caracterizada pela divisão centro-periferia, mas também resultava em uma alteração nas relações entre os países da região onde se verificava a emergência do subcentro econômico. No caso, a ascensão do Brasil e a sua consolidação como importante exportador de manufaturados na região da América do Sul, diferenciava-o dos demais países que passavam a experimentar um aprofundamento de sua especialização produtiva:

Tudo isso configura um processo de integração na América Latina que se desenvolve em dois planos: a rearticulação da economia latino-americana em seu conjunto com a economia mundial, sobre a base do desenvolvimento de uma economia exportadora de tipo industrial, e a redefinição da relação econômica entre os próprios países da zona. A superespecialização vem a ser assim a contraparte de uma intensificação da dependência e se realiza sobre a base do que se acreditou, até há pouco, ser a chave para a emancipação econômica da América Latina: o desenvolvimento industrial (Marini, 1976 apud Luce, 2013a:133. Grifos nossos).

Todos os aspectos citados até agora compõem o ponto de vista “estritamente econômico" do subimperialismo. Nesses termos, Marini (1976:40) indicou que o subimperialismo se definia em função de dois traços centrais: 
a) A partir da reestruturação do sistema capitalista mundial, que deriva em uma nova divisão do trabalho;

b) A partir das leis próprias da economia dependente, essencialmente: a superexploração do trabalho; o divórcio entre as fases do ciclo do capital; a monopolização extrema; e a integração do capital nacional ao estrangeiro (integração dos sistemas de produção).

Por outro lado, o subimperialismo também comportava variáveis políticas. Em uma definição mais geral, Marini (1977:17) indicou que o subimperialismo implicava em dois componentes básicos: de um lado, uma "composição orgânica média" na escala mundial dos aparelhos produtivos nacionais - isto é, um desenvolvimento econômico relativamente mais avançado - e por outro, o exercício de uma "política expansionista relativamente autônoma".

Esse segundo componente se refere à tendência de reforço do Estado subimperialista, que seria determinante para organizar a integração imperialista, processo que não implicava em uma simples submissão do Estado ao capital internacional, mas passava por uma negociação ${ }^{26}$. Também diz respeito à capacidade do Estado subimperialista de impulsionar a sua política de hegemonia regional, no contexto da busca por esferas próprias de influência e para o estabelecimento de uma divisão desigual do trabalho em seu proveito ${ }^{27}$. Finalmente, ao considerar todas essas variáveis, Marini (1977) chegava à conclusão de que, na América Latina, apenas o Brasil expressava plenamente a condição de subimperialista.

Dentre as diversas manifestações da nova situação do capitalismo brasileiro, Marini (1976 apud Luce, 2011) ressaltou o aprofundamento de um padrão de intercâmbio desigual na região (olhando as cifras do comércio regional), onde o Brasil passava a ocupar uma função diferenciada de economia exportadora de tipo industrial, com a "superespecialização" dos demais países como contrapartida, em especial, dos países de menor desenvolvimento relativo como Bolívia, Paraguai e Uruguai. Esses países, por sua parte, passavam a

\footnotetext{
${ }^{26} \mathrm{O}$ conceito utilizado por Marini para explicar essa dinâmica foi o de "cooperação antagônica", que expressava a situação de barganha dentro do processo de integração imperialista, onde os grupos e nações subordinadas buscariam melhorar as condições de sua subordinação, em vez de adotar uma atitude de confrontação direta ou de se submeter de forma automática ao domínio imperialista (Luce, 2007; 2011).

${ }^{27}$ Para uma explicação mais detalhada sobre essas premissas, conferir a nota de rodapé n. 23.
} 
constituir mercados para as exportações de bens manufaturados produzidos no Brasil, sendo induzidos a uma maior especialização na produção de bens de menor valor agregado e matérias-primas.

Com relação às manifestações do subimperialismo no Paraguai - referente ao tema do presente trabalho - o caso do aproveitamento assimétrico do potencial hidrelétrico da repressa de Itaipu, que começou a ser construída como uma iniciativa binacional sobre o Rio Paraná na fronteira entre o Brasil e o Paraguai em 1973, foi apontado por Marini (1976) como exemplo da expansão brasileira na busca pelo controle de fontes de energia, essenciais para seu projeto de industrialização. Já o caso do estabelecimento de produtores rurais brasileiros na região fronteiriça do Paraguai por volta dos anos 1970, embora não tenha sido contemplado pelo autor, também constituiu parte do fenômeno.

Em seus estudos sobre a evolução histórica da teoria e do fenômeno do subimperialismo, Luce $(2007 ; 2011)$ resgatou esse evento, indicando que a política dos governos militares brasileiros naquele período foi de apoiar essa transferência dos agricultores e pequenos proprietários de terra para o outro lado da fronteira que, além de atender a objetivos geopolíticos, cumpriu a função de deslocar - ou "exportar" - as contradições internas do capitalismo brasileiro, contribuindo para aliviar em certo grau (e ao menos, temporariamente e em alguns estados) as tensões sociais no campo, decorrentes do avanço da produção mecanizada no território brasileiro ${ }^{28}$.

\subsection{1}

\section{Atualidade da teoria e do fenômeno do subimperialismo brasileiro}

A despeito da especificidade histórica da emergência do subimperialismo brasileiro, o fenômeno ganha forma na atualidade, especialmente, ao verificar-se novas tendências como a crescente exportação de capitais de empresas multinacionais de matriz brasileira. Com efeito, a teoria do subimperialismo vem sendo recuperada para dar conta dessas novas manifestações, assim como das

\footnotetext{
${ }^{28}$ Luce (2011) também sugere que esse caso específico - assim como a expansão de produtores para o território boliviano - pode ser considerado como uma exceção ao pressuposto de Marini de que a espoliação realizada no exterior pelo subimperialismo brasileiro não conseguiria ser convertida em um fator de elevação do nível de vida de sua população. No caso, a transferência desses produtores para os países vizinhos contribuiu para apaziguar, em certo grau, as tensões do avanço do capitalismo no campo no Brasil.
} 
atuais condições de expansão da economia capitalista mundial que circunscrevem o fenômeno - acompanhando o movimento de ressurgimento geral das discussões sobre a dependência.

Tanto o fenômeno quando os estudos sobre o subimperialismo ressurgem com força a partir da década de 2000, após um período de "arrefecimento das relações subimperialistas" - desde a segunda metade da década de 1980 e, sobretudo, ao longo da década de 1990 - onde as dinâmicas imperialistas retomaram dos países intermediários as margens de poder que estes haviam adquirido nas décadas anteriores, resultando em uma inserção passiva do Brasil na nova dinâmica política e econômica mundial (Bueno e Seabra, 2009; Luce, 2007). Trata-se do período da ofensiva neoliberal, que pregava uma maior abertura e liberalização econômica, assim como um maior "afastamento" dos Estados da dinâmica econômica, e que se apresentou como a grande solução aos problemas de estagnação econômica que vinham afetando os países da região desde meados da década de 1980.

Conforme apresentado na seção anterior, para as perspectivas mais críticas, esse período (popularizado como a era da "globalização"), representou um aprofundamento da expansão da economia capitalista na região - ou, um aprofundamento da integração dos sistemas produtivos, porém, sobre novas bases (isto é, mudaram as formas, mas não a essência desses processos). Em termos das implicações dessas mudanças para o fenômeno subimperialista, Luce (2013a:138) explica que:

Nos dias atuais, sob o novo padrão exportador de especialização produtiva ${ }^{29}$, a indústria de transformação cedeu ligar às indústrias extrativas. E as matériasprimas despontaram novamente como o segmento que imprime dinamismo ao padrão de reprodução, alterando a forma histórica da dependência. Esses segmentos, juntamente com a valorização financeira em si e alguns poucos ramos do padrão anterior (especialmente a indústria automobilística) são a pedra de toque do capitalismo brasileiro nesse começo de século. (Grifos nossos).

Ou seja, o capital internacional se associou às classes dominantes dos países dependentes promovendo novos ramos e setores, mas mantendo a lógica de subordinação aos interesses do primeiro. No caso do Brasil, antigos e novos

\footnotetext{
${ }^{29} \mathrm{Na}$ atualização da teoria do subimperialismo, Luce $(2011 ; 2013 \mathrm{a})$ recorre ao esquema teórico do "padrão de reprodução do capital", desenvolvido por Jaime Osório - conferir nota de rodapé n. 21. Seguindo a mesma linha de raciocínio proposta por Osório, Luce (2013a) conclui que o subimperialismo mudou as formas pelas quais se manifesta, mas mantém a sua essência.
} 
trustes capitalistas brasileiros passaram a expandir seus negócios, recebendo um forte apoio do Estado - por meio do BNDES, principalmente - com destaque para os grupos empresariais como: as mineradoras Vale e Votorantim, a Petrobrás, a construtora Odebrecht, e as processadoras de carne JBS-Friboi e Marfrig. De acordo com Luce (2013a), hoje, esses setores são os responsáveis por aprofundar a tendência da superexploração da força de trabalho e a cisão entre a estrutura produtiva e a necessidades de consumo das amplas massas, tendências que se verificam em fatos como: o maior frigorífico do mundo (JBS) fazer parte de um país com uma população com sérios problemas de nutrição; e uma das maiores construtoras do mundo pertencer a um país onde as classes trabalhadoras gastam, em média, quatro horas para se deslocar até o local de trabalho em suas cidades.

Da mesma forma, verifica-se que o subimperialismo alterou as formas pelas quais se manifesta externamente, sem modificar a lógica de diferenciação que engendra em sua busca por mercados e fontes de recursos e matérias primas no exterior. Se no período do auge da indústria manufatureira, o estabelecimento de uma divisão regional desigual do trabalho pelo subimperialismo ganhou forma com a expansão das exportações brasileiras de bens manufaturados, atualmente o formato de exportação de capitais (destinados, principalmente, para os países da América do Sul) tem ganhado proeminência. Por outro lado, as exportações de bens continuam a ser um meio importante para a realização do capital investido no Brasil - como se verifica pelos grandes volumes de exportações do setor do agronegócio; e também de alguns bens manufaturados (como veículos motorizados), que se destinam amplamente para a região da América do Sul. Nesse contexto, fatores como a ascensão da China como principal mercado das exportações brasileiras - em detrimento dos EUA ou da EU - em nada altera a lógica das relações imperialistas que, conforme Luce (2013a:139), ainda "finca raízes na nossa sociedade e segue provocando o despojo dos povos no continente".

Por fim, a persistência do subimperialismo brasileiro se deve à manutenção de uma política de "cooperação antagônica" com os centros imperialistas, que lhe permite exercer a sua autonomia relativa e colocar em prática uma política de hegemonia regional. A esse respeito, Luce (2013a) ressalta que, à diferença de outras nações, o Estado brasileiro não foi simplesmente absorvido pela ofensiva do capital estrangeiro nos anos 1990, mas atuou como 
coadjuvante dos processos de desnacionalização da época. Nesse âmbito, o agronegócio se coloca como um exemplo claro da lógica de cooperação antagônica praticada pelo governo brasileiro, na medida em que, apesar da aparente postura de confrontação aos países centrais nas instâncias de negociação multilaterais no tema da agricultura, o Brasil não adotou medidas para frear o avanço das transnacionais e a prevalência da monocultura em seu território, ou nos demais países da região (Luce, 2007).

Em suma, da mesma forma que as demais premissas da vertente marxista da dependência, o subimperialismo ganha relevância atual perante o acirramento da expansão da economia capitalista mundial e das tendências de concentração e de polarização social que acompanham esse processo. Fundada a partir de uma base teórica robusta, as reflexões em torno do subimperialismo contribuem, da mesma foram que o fizeram na época de seu surgimento, para as discussões atuais sobre o fenômeno do imperialismo, que são cada vez mais sensíveis às matizes regionais e nacionais. Constitui, assim, uma ferramenta crítica central para pensar a respeito da ascensão atual do Brasil na dinâmica econômica mundial e regional e, principalmente, para compreender as características (e os paradoxos) de sua expansão para outras economias dependentes - no caso, para a economia paraguaia, que diz respeito ao foco do presente estudo. 


\section{3. \\ O desenvolvimento da agricultura capitalista e a sua expansão na América Latina}

Atualmente, o modelo da agricultura capitalista (ou agronegócio) ${ }^{30}$ se coloca como a forma hegemônica de organização das atividades agrárias na maior parte dos países da América Latina. Trata-se de um modelo intensivo no uso de capital e estreitamente vinculado a circuitos mundiais de produção e circulação de matérias primas agrícolas, alimentos, e outros produtos agroindustriais. De fato, a ascensão desse modelo e o rápido desenvolvimento rural dos países latinoamericanos nas últimas décadas do século $\mathrm{XX}$, corresponderam a uma maior integração dos mercados e estruturas produtivas desses países aos mercados mundiais.

A consolidação das "cadeias agro-alimentares globais" e o ritmo do desenvolvimento agrícola dessas sociedades, contudo, são amplamente conduzidos pelas corporações transnacionais do agronegócio - notavelmente, de origem europeia e estadunidense - que controlam o desenvolvimento das novas tecnologias de produção, assim como grande parte dos fluxos comerciais de bens agrícolas a nível mundial. Nesse sentido, os países latino-americanos experimentam um processo de desenvolvimento agrícola e de integração econômica desigual, que os coloca em uma condição de subordinação.

A fim de compreender a configuração contemporânea das relações econômicas internacionais no âmbito da agricultura - e entender o caráter subjacente aos processos de desenvolvimento rural dos países latino-americanos

\footnotetext{
30 "Agronegócio" é o termo comumente utilizado para designar o modelo de produção agrícola altamente mecanizado e integrado com os mercados mundiais, onde a produção passa a ser cada vez mais pautada pela lógica do "negócio" (i.e., do constante aumento da rentabilidade), em detrimento dos objetivos de subsistência ou autoconsumo (Rojas, 2009). Nesse sentido, entende-se que o modelo do "agronegócio" se constitui dentro do paradigma da "agricultura capitalista" (ou moderna) e, por isso, no presente trabalho tais termos são tratados como equivalentes. Com efeito, o agronegócio também é frequentemente descrito como o estágio atual (mais avançado) do contínuo processo de desenvolvimento da agricultura capitalista - ver Fernandes (2008); Giarraca e Teubal (2008). A respeito desse processo, é preciso ressaltar que o presente trabalho não pretende aprofundar-se na discussão sobre seus diversos desdobramentos - em função de restrições de espaço e do escopo da pesquisa - buscando-se, apenas, apontar as evidências da predominância desse modelo a nível mundial (e, em especial, nos países da América Latina), assim como suas principais características.
} 
nas últimas décadas - o presente capítulo realiza uma breve revisão histórica sobre o desenvolvimento da agricultura moderna (isto é, sobre o processo de industrialização da agricultura) e a forma pela qual esse paradigma se expandiu pelo resto do mundo, particularmente, na região da América Latina. Nessa trajetória, verifica-se que o modelo da agricultura moderna encontrou amplo espaço para seu desenvolvimento nos Estados Unidos, expandindo-se, a partir daí, para outras partes do mundo, sob a liderança das corporações estadunidenses - e com forte respaldo do governo dos EUA. Dessa forma, a agricultura se constituiu um pilar central ascensão hegemônica dos EUA na economia mundial desde meados do século XX.

Ao destacar os acontecimentos específicos do âmbito da agricultura, o presente capítulo busca resgatar a centralidade desse setor na configuração da ordem econômica mundial. De acordo com Magdoff, Bellamy e Butter (2000), na visão convencional da economia política, geralmente, a agricultura é retratada como um setor que foi deslocado pela indústria, deixando a muitos observadores com a impressão de que lidar com o tema é analisar a economia política histórica, e não contemporânea. Nessa mesma linha, McMichael (2000:127) ressalta que, a representação das desigualdades nas relações econômicas internacionais, isto é, o esquema da "divisão internacional do trabalho" - consistente na distinção entre o centro (especializado nas atividades industriais) e a periferia (especializada na produção de alimentos e matérias primas) - reforçou o "viés urbano-industrial" dos estudos sobre o desenvolvimento econômico. Com efeito, isso pode ser constatado nas análises apresentadas no capítulo anterior onde, a maior parte das discussões se orientou para a questão da industrialização (isto é, produção de bens manufaturados e bens de capital), obscurecendo a história paralela das políticas do agronegócio como importantes moldadoras da economia mundial e das relações de poder.

Nesse sentido, o presente capítulo se coloca como um complemento do primeiro, buscando apontar os aspectos da organização da produção e comercialização de alimentos e matérias primas agrícolas a nível mundial como elementos centrais da determinação dos processos de desenvolvimento dos países latino-americanos e de sua inserção subordinada à economia mundial. Dessa forma, consegue-se aprofundar a compreensão sobre as dinâmicas da divisão internacional do trabalho e das relações de dependência, principalmente, no 
período atual, onde o dinamismo econômico da maior parte dos países latinoamericanos se assenta em atividades relacionadas ao setor agrícola. Portanto, a ênfase na geopolítica da agricultura ganha mais relevância do que nunca.

\section{1 \\ Da Revolução Verde à Revolução Biotecnológica: o desenvolvimento da agricultura moderna sob o comando estadunidense}

O advento da agricultura moderna implicou a emergência de novos padrões no processo de desenvolvimento econômico nacional, e de novas tendências nas relações econômicas internacionais em torno da produção e circulação mundial de alimentos e matérias-primas agrícolas. Um dos principais aspectos da gestação desse modelo e da sua ampliação a nível mundial foi a centralidade assumida pelos Estados Unidos e suas forças econômicas nesses processos.

O desenvolvimento da agricultura moderna - referente aos processos de refinamento e melhor aproveitamento dos componentes biológicos das plantas (especialmente das sementes) $)^{31}$, e de contínua incorporação de máquinas ao processo de produção - ganhou amplo impulso nos Estados Unidos, por volta da década de 1930 (Otero, 2008). O apoio do governo estadunidense à atividade agrícola, que havia sido severamente afetada pelos acontecimentos da Grande Depressão, tinha como principal finalidade aumentar a produtividade de alimentos no país. Nesses termos, a crescente industrialização da agricultura demonstrou ser, de fato, bem sucedida, ao atingir altos níveis de produtividade.

Por outro lado, a consolidação de uma agricultura altamente produtiva e intensiva em capital e energia, ocasionou profundas mudanças na estrutura socioeconômica do país, com destaque para a emergência e o fortalecimento dos "complexos agroindustriais" - estruturas produtivas que representavam a crescente integração entre as atividades agrícolas e as atividades industriais. Conforme Otero (2008), ao longo do desenvolvimento dessa estrutura, dois segmentos ganharam proeminência, tornando-se os principais condutores do processo de industrialização da agricultura: de um lado, o segmento da produção

\footnotetext{
${ }^{31}$ Como marco da ascensão da agricultura moderna, Otero (2008) ressalta a introdução do milho híbrido (e de outras variedades melhoradas de cultivos); de produtos químicos como fertilizantes, pesticidas, herbicidas; e de maquinários e equipamentos cada vez mais sofisticados.
} 
de insumos agrícolas, onde os produtores detinham um forte controle sobre o preço de seus produtos (caracterizando uma estrutura "oligopolista"); e de outro, o segmento de processamento e comercialização, onde os compradores dos alimentos ou matérias primas agrícolas, a serem processadas ou comercializadas, conseguiam ter um amplo controle sobre os preços de compra desses bens (representando uma estrutura "oligopsonista") ${ }^{32}$.

Em outras palavras, com o progressivo desenvolvimento da agricultura moderna, enraizava-se uma estrutura aonde os produtores rurais e fazendeiros iam perdendo cada vez mais peso com relação aos novos atores agroindustriais (dos setores de insumos e de processamento), que exerciam um maior poder de mercado. Assim, diante do contínuo aumento dos custos de produção no campo em função dos insumos cada vez mais sofisticados que deviam ser incorporados aos processos produtivos - e da crescente perda do poder de negociação dos preços de seus produtos com os grandes compradores, muitos produtores e fazendeiros encontraram dificuldade para continuar no ramo.

De fato, ao longo da segunda metade do século XX, os EUA vivenciaram uma diminuição dramática no número total de fazendas no país - de 7 milhões em 1935, para quase 2 milhões em 1997 (Otero, 2008:8), e o concomitante aumento do tamanho médio das mesmas, que evidenciava a tendência crescente para a produção em grande escala (preconizada, pelo modelo da agricultura moderna). Assim, o avanço da agricultura industrializada nos EUA resultou em tendências, cada vez mais acirradas, de centralização e concentração no setor agrícola, especialmente, nos segmentos que controlavam o ritmo de sua expansão (isto é, o de produção de insumos, e o de processamento e comercialização) ${ }^{33}$.

\footnotetext{
32 "A oligopsonistic structure" (Otero, 2008:10).

${ }^{33}$ Nas discussões a respeito da industrialização da agricultura, a abordagem de Goodman, Sorj e Wilkinson (2008), é perspicaz em explicar a lógica e as limitações desse processo. Focando nos aspectos próprios da atividade agrícola, isto é, na sua base natural, os autores indicam que a industrialização da agricultura não consegue se estabelecer em um processo unificado, acontecendo, então, de forma parcial e descontínua. Conforme Goodman et. al. (2008:1), a industrialização da agricultura - diferente do processo de industrialização convencional (de bens manufaturados) - é determinada pelas "limitações estruturais" do processo de produção agrícola, representadas pela natureza: (1) enquanto conversão biológica de energia; (2) enquanto tempo biológico no crescimento das plantas e na gestação animal; (3) enquanto espaço nas atividades rurais baseadas na terra. O que acontece, então, são apropriações de elementos pontuais do processo de produção agrícola pela lógica industrial, por exemplo, do trabalho humano pelas máquinas, ou das técnicas naturais de plantio por métodos consistentes na utilização de agroquímicos e variedades de cultivo melhoradas. Esse processo é denominado pelos autores como "apropriacionismo" que, em seu sentido mais pleno, consiste no esforço de reduzir a importância da natureza na produção rural. Além das apropriações, acontece também um contínuo
} 
Enquanto isso, os índices de produtividade agrícola que estavam sendo obtidos no país foram tais que chegaram a superar a demanda interna. Os excedentes produzidos ficaram disponíveis para exportação e tornaram-se, dessa forma, um componente estratégico da política externa dos Estados Unidos naquela época (no período após a Segunda Guerra Mundial) - marcada pelos programas de ajuda à restauração das economias europeias, e também pelo apoio ao processo de desenvolvimento dos países do "terceiro mundo". Foi nesse contexto de prosperidade econômica e ascensão internacional dos Estados Unidos que se desdobrou a chamada "Revolução Verde":

O paradigma tecnológico da agricultura moderna envolve um pacote específico de insumos composto por cultivos híbridos e outras variedades de alto rendimento; mecanização; fertilizantes e pesticidas agroquímicos; e irrigação. A "Revolução Verde" é o nome adotado por este pacote tecnológico quando passou a ser exportado para os países em desenvolvimento (...). Esse pacote exportado se tornou posteriormente o "paradigma tecnológico" para a agricultura moderna por todo o século XX (Otero e Pechlaner, 2008:32. Tradução própria).

Assim, uma parte importante dos excedentes agrícolas foi canalizada para o exterior por meio de programas de ajuda alimentar. Por sua parte, as tecnologias do pacote da agricultura moderna (desenvolvidas e produzidas nos EUA) também encontraram espaço nas exportações por meio dos programas de ajuda externa para o desenvolvimento - por exemplo, o Plano Marshall (destinado aos países europeus), e a já mencionada Revolução Verde, orientada para regiões específicas do "terceiro mundo". Conforme McMichael (2000), esses dois programas impulsionaram a modernização dos setores agrícolas nos países aos quais se destinavam - desde a Europa, passando pelo Japão e chegando até o México replicando o modelo agrícola estadunidense, intensivo em capital e energia.

desenvolvimento de substitutos industriais para os bens agrícolas, processo denominado pelos autores como "substitucionismo", que consiste tanto na substituição direta, como na redução dos bens agrícolas à condição de insumos industriais básicos, aumentando assim a possibilidade de equivalência e intercâmbio entre diferentes matérias primas. A partir dessas explicações, pode-se entender a cisão que se estabelece no processo de industrialização da agricultura, colocando de um lado as atividades de cunho industrial (a produção de insumos e o segmento de processamento), e de outro as atividades de produção (cultivo) em si, onde as primeiras passam a se constituir nos segmentos estratégicos do processo como um todo, na medida em que controlam o seu dinamismo e o seu ritmo de desenvolvimento. Por outra parte, o esquema de Goodman et. al. (2008), ao resaltar o elemento natural da agricultura e os limites que coloca à industrialização, ajuda a compreender a persistência da agricultura como uma atividade rural - isto é, a entender a sua maior rigidez (sobretudo, territorial) com relação a outros processos industriais - apesar dos progressos técnicos. 
As empresas que comandavam o desenvolvimento do complexo agroindustrial nos Estados Unidos passaram assim a se beneficiar pela disposição de novas regiões fornecedoras de matérias-primas agrícolas e de novos mercados para suas tecnologias, tornando-se agentes centrais na organização dos complexos agroindustriais nos países receptores desses programas de ajuda. Controlando um volume de operações cada vez maior, e ampliando seu alcance internacional, essas empresas passaram a coordenar grande parte das trocas comerciais (seja de insumos agrícolas ou produtos agrícolas) e dos fluxos de investimentos no setor a nível mundial, dando lugar à consolidação das grandes corporações do agronegócio.

Em outras palavras, os complexos agro-industriais (onde a agricultura está sujeita, e integrada aos processos industriais) estavam sendo, simultaneamente, organizados em nível nacional, e aprovisionados em nível internacional (McMichael, 2000:129. Tradução própria).

Isto é, as corporações do agronegócio não apenas contavam com novos mercados domésticos onde vender suas tecnologias, mas também passaram a integrar cadeias globais de commodities, ligando sub-setores agrícolas especializados para além das fronteiras nacionais (McMichael, 2000:131. Tradução própria. Grifos nossos).

Assim, o modelo de agricultura moderna, gestado, inicialmente, nos Estados Unidos, foi sendo transferido para diversos países da América Latina, sob a liderança dos agentes econômicos estadunidenses. Dessa forma, reproduziramse nas sociedades latino-americanas as mesmas lógicas e estruturas produtivas desse modelo, e também seus resultados (tanto em termos de produtividade, como das implicações socioambientais). A esse respeito, Otero e Pechlaner (2008) apontam que, os impactos da introdução da agricultura moderna na América Latina se assemelham, em grande medida, àqueles apontados para os Estados Unidos, sendo, porém, mais graves, por conta de duas diferenças centrais entre essas ambas as situações.

A primeira refere-se ao firme processo de industrialização que estava em curso nos Estados Unidos, e que foi capaz de absorver as populações deslocadas da atividade rural pelo avanço da mecanização no campo. Diferentemente, os países da América Latina enfrentaram um maior crescimento do desemprego (e do 
subemprego) nas cidades, que se mostraram incapazes de absorver, de forma efetiva, as populações rurais deslocadas pelo avanço da modernização agrícola ${ }^{34}$.

A segunda diz respeito ao fato de que, a adoção do padrão da agricultura moderna nos países da América Latina, aconteceu em áreas específicas (de maior irrigação), levando a um aumento das diferenças regionais (entre países e no interior dos mesmos). Já nos Estados Unidos, o modelo foi disseminado de forma geral. Com efeito, ao analisar as estruturas agrárias atuais dos países da América Latina, Piñeiro (2004) aponta que os complexos agro-industriais tornaram-se a forma "predominante" da agricultura capitalista (ou moderna) nessas sociedades, indicando que ainda persistem outras formas de organização das atividades rurais - e configurando, assim, estruturas altamente heterogêneas que sinalizam as fortes desigualdades sociais existentes nesses países ${ }^{35}$.

Enfim, o desenvolvimento da agricultura moderna e a sua difusão para os países da América Latina, sob o comando dos Estados Unidos e seus agentes econômicos, mais do que resultados de um programa de ajuda ao desenvolvimento (em busca da solução pelos problemas sociais da pobreza e da fome), representaram uma expansão dos modelos capitalista e agrícola dos EUA para esses países (Otero e Pechlaner, 2008), na busca de uma ampliação de suas bases de acumulação.

Esses processos de desenvolvimento e integração no âmbito agrícola assim como as tendências de centralização e concentração que induzem, tanto no nível das estruturas nacionais como das dinâmicas mundiais - irão ganhar novo impulso desde os anos 1990, a partir do contínuo desenvolvimento de inovações tecnológicas, principalmente, dos avanços em torno da biotecnologia

\footnotetext{
${ }^{34}$ Além disso, os autores indicam que os processos de transição para a agricultura moderna e de urbanização nos países latino-americanos aconteceram a um ritmo mais acelerado do que nos Estados Unidos. E que, o padrão histórico de distribuição da terra nesses países - profundamente desigual desde a época da colonização - também constitui um fator que exacerbou as tendências de polarização social advindas com a instalação do modelo da agricultura moderna.

${ }^{35}$ Piñeiro $(1996$; 2004) indica que a extensão e a profundidade do domínio dos complexos agroindustriais (ou das cadeias agro-alimentares) na América Latina variam de acordo com o país em foco (ou com os bens que são produzidos). Para o autor, os estudos sobre a realidade agrária latino-americana devem, então, considerar o caráter desigual e parcial das transformações sociais provocadas pela modernização agrícola, reconhecendo a coexistência de diversos atores: além das empresas (nacionais ou transnacionais) que compõem o núcleo dos complexos agro-industriais, têm-se unidades e agentes que se caracterizam por trabalhar com formas "não capitalistas" de produção, como os campesinos, as empresas familiares e pequenos produtores, vinculando-se aos complexos de forma subordinada; e por fim, tem-se também a massa de camponeses pobres (de escassos recursos ou "sem terra") que, apesar da exclusão sofrida pelo modelo, permanecem no campo (perante a falta de oportunidades nos centros urbanos), marcando uma presença social relevante - especialmente, no contexto das manifestações de resistência ao avanço do modelo.
} 
(inaugurando a era da "Revolução Biotecnológica"), e com o advento da "globalização neoliberal", referente ao aprofundamento da integração econômica entre os países, que irá consolidar o marco legal e institucional "corporativo" do desenvolvimento e expansão mundial da agricultura moderna.

Por outro lado, a persistência, e em diversos casos, o agravamento das problemáticas da exclusão social e da fome, sobretudo, nos países da periferia do sistema mundial - que haviam se colocado como os grandes desafios da Revolução Verde - vai abrir cada vez mais espaço para o surgimento de críticas e questionamentos a respeito da efetividade do paradigma da agricultura moderna para lidar com esses problemas.

Enquanto a Revolução Verde foi indisputavelmente bem sucedida em aumentar a produção de alimentos em regiões vulneráveis, é decididamente menos certo qual tem sido seu real impacto na redução da fome. Críticos da Revolução Verde tem argumentado que seu impacto no aumento da produtividade não necessariamente se traduziu em menos fome (Otero e Pechlaner, 2008:36. Tradução própria).

Nesse novo contexto, de acirramento das tendências mencionadas, também ganhará força a percepção de que a expansão mundial da agricultura moderna responde a interesses particulares de grupos corporativos oriundos dos países centrais - notadamente, dos Estados Unidos e de alguns países europeus principalmente, quando se verifica que as novas tecnologias introduzidas não rompem com o padrão de produção anterior, colocando-se como fatores que, em lugar de encontrar soluções definitivas para os problemas sociais e ambientais provocados pelo modelo da agricultura moderna, irão agravá-los.

O capitalismo nos apresenta à paradoxal realidade de um rápido crescimento da produção de alimentos e perpetuação da superprodução (...) por um lado, acompanhada pelo reforço da exclusão social e assim também pelo crescimento da fome, pelo outro. Este último não é, como se pensa às vezes, principalmente o resultado do crescimento populacional (...), mas ao contrário, uma consequência do fato que o objeto imediato da produção de alimentos não é o sustento humano ou seu bem-estar, mas o crescimento dos lucros (Magdoff et. al. 2000:9. Tradução própria. Grifos nossos).

Em outras palavras, pode-se afirmar que a lógica de ampliação das bases de acumulação - ou o caráter imperialista do processo de integração dos países latino-americanos à economia (agrícola) mundial (na linguagem dos teóricos dependentistas) - por trás da expansão mundial do modelo do agronegócio se 
torna cada vez mais evidente no início do novo século, como o fazem também as manifestações de resistência ao avanço desse modelo.

\section{2 \\ Globalização neoliberal, cadeias agro-alimentares globais e corporações transnacionais: a configuração das relações internacionais contemporâneas no âmbito da agricultura}

Desde os anos 1990, o desenvolvimento da agricultura moderna e a sua difusão em nível mundial ganham novo impulso a partir do desdobramento de dois aspectos centrais: (a) de um lado, a incorporação de novas tecnologias ao processo produtivo, principalmente, aquelas relacionadas à biotecnologia (consistentes em técnicas cada vez mais refinadas, como a manipulação genética e a criação de cultivos transgênicos), que passam a reforçar o padrão de produção agrícola intensivo em capital e energia; (b) e de outro, o aprofundamento da integração econômica entre os países, por meio da colocação em marcha de uma nova agenda política e econômica (o modelo "neoliberal"), que contribuiu para a consolidação do marco "corporativo" (isto é, de uma estrutura fortemente oligopolizada pelas firmas transnacionais do agronegócio) que pauta o desenvolvimento da agricultura em nível local e global (Otero, 2008).

As novas biotecnologias caracterizam uma nova revolução na agricultura no sentido de que incrementam, significativamente, a produtividade, além de terem impactos sociais e ambientais mais profundos. Porém, de acordo com Otero (2008), essas novas tecnologias não assinalam uma revolução no sentido de transcender o paradigma tecnológico da agricultura moderna e da Revolução Verde, que se orientava, principalmente, a melhorar a produtividade das operações de produção em grande escala (pelo uso intensivo de insumos de capital, em vez de trabalho humano), resultando em uma crescente marginalização dos pequenos produtores e camponeses, e em um consequente acirramento dos problemas de desemprego, da exclusão social e da fome - sobretudo, nos países dependentes. Assim, na medida em que as novas biotecnologias se inserem nesse padrão produtivo intensivo em capital e energia, levantam questionamentos e 
preocupações a respeito de sua eficácia para combater os problemas mencionados ${ }^{36}$.

Todavia, é preciso ressaltar que a problemática não se refere tanto às tecnologias em si - isto é, não significa que elas sejam nocivas por si só - mas a quem as está promovendo e para que. No atual contexto da "Revolução Biotecnológica", entidades privadas e empresariais são os principais promotores da agenda de pesquisa e desenvolvimento de novas tecnologias agrícolas, diferentemente da época da Revolução Verde (entre as décadas de 1940 e 1970), onde esse papel pertencia, principalmente, a instituições de caráter público (Otero 2008; 2012). Além disso, na conjuntura atual, as tendências de centralização e concentração nesse segmento têm se acirrado ${ }^{37}$.

Nessas condições, Otero e Pechlaner (2008) indicam que as prioridades de cunho social passam a perder espaço para os objetivos de maximização dos lucros. Um exemplo disso é a ênfase dada pelas corporações transnacionais ao desenvolvimento de pacotes de insumos tecnológicos (i.e., de sementes adequadas para o uso de certos herbicidas) que constitui, acima de tudo, uma estratégia de marketing para o aumento das vendas dos produtos. Da mesma forma, os cultivos transgênicos (e suas propriedades específicas) são, geralmente, desenvolvidos em função das necessidades das indústrias (seja de alimentos ou outros produtos

\footnotetext{
${ }^{36}$ Além de aprofundar os efeitos de polarização social, os novos produtos da biotecnologia levantam preocupações a respeito de seus impactos ambientais específicos, como: a questão da segurança dos alimentos produzidos com base em cultivos geneticamente modificados (e seus possíveis impactos na saúde humana); a questão da "contaminação genética", entre cultivos naturais e cultivos geneticamente modificados, levando a resultados inesperados; e a perda de biodiversidade, acelerada com a adoção dos cultivos transgênicos, pois estes incentivam o monocultivo em grande escala (Otero e Pechlaner, 2008).

${ }^{37} \mathrm{O}$ desenvolvimento das novas biotecnologias, e as tendências de concentração industrial em torno das mesmas, começaram a ganhar impulso anos 1980. Uma das principais características desse processo, diz respeito às fusões entre empresas da indústria química e farmacêutica e firmas fabricantes de sementes, que representou uma importante estratégia dessas empresas no sentido de canalizar esforços e investimentos para o controle de novos mercados e a maximização de seus lucros. No caso da indústria química, por exemplo, a associação com as empresas de sementes constituiu uma importante estratégia de "integração horizontal", na medida em que as sementes se colocam como um dos principais veículos para a comercialização de outros produtos (como os agroquímicos). Com efeito, uma grande parte da agenda de desenvolvimento das novas biotecnologias se voltou para a elaboração de sementes resistentes a certos tipos de agroquímicos, que passaram a ser vendidos, posteriormente, como pacotes de insumos inseparáveis para a produção agrícola (Otero e Pechlaner, 2008; Goodman et. al., 2008). No próximo capítulo, pode-se apreciar o grau de concentração nesse segmento, ao verificar-se que as maiores empresas de produção e comercialização de sementes também são as maiores no mercado de agroquímicos. A esse respeito, ver também as Figuras 13 e $\mathbf{1 4}$ no Anexo.
} 
agroindustriais), e muitas vezes, em prejuízo das necessidades humanas ou ambientais $^{38}$.

A centralidade assumida pelas corporações transnacionais no processo de industrialização da agricultura aconteceu, em grande parte, graças ao forte apoio dos Estados Unidos. No seu âmbito doméstico, o governo dos Estados Unidos foi responsável por promover diversos incentivos financeiros e políticos em benefício, tanto das agendas de pesquisa e desenvolvimento dessas grandes empresas, como da consolidação de sua posição de liderança nesse segmento (Otero, 2008). O apoio do governo estadunidense também foi crucial para expansão e consolidação dessas empresas na esfera internacional. Todavia, nesse âmbito, a situação se potencializou a partir a nova agenda de desenvolvimento e integração econômica neoliberal avançada ao redor do mundo, nas últimas décadas do século XX.

Basicamente, essa agenda foi marcada pela promoção de reformas políticas e econômicas fortemente assentadas nos princípios do respeito irrestrito à propriedade privada, ao livre mercado e ao "distanciamento" do Estado das atividades econômicas. Nos países da América Latina - que, em sua maioria, estava atravessando por um momento de crise e estagnação econômica - a consecução das reformas neoliberais implicou a adoção de uma série de medidas que se orientavam a uma eliminação total das barreiras aos fluxos de bens e de capitais. Tratou-se, contudo, de um processo de liberalização e integração desigual, na medida em que, nos países centrais - como os Estados Unidos e os países da União Europeia - as reformas foram aplicadas de forma parcial. No contexto da agricultura, por exemplo, enquanto os governos dos países latinoamericanos tiveram que abandonar várias de suas políticas protecionistas e de subsídio ao setor, os países centrais conseguiram mantê-las, assegurando maiores vantagens para seus produtos e seus produtores.

Por sua parte, as corporações transnacionais do agronegócio se viram favorecidas com a abertura de novos mercados para seus produtos, ao mesmo tempo em que, viram a sua posição hegemônica na dinâmica agro-alimentar

\footnotetext{
${ }^{38}$ Cultivos como soja, milho e canola ganham destaque nesse contexto, pois constituem cultivos "básicos" (ou flexíveis), isto é, que podem ser utilizados em diversos processos industriais - para a produção de alimentos, biocombustíveis, ou outros produtos. Dessa forma, são também os cultivos mais modificados geneticamente, colocando-se como objeto central das agendas de pesquisa e desenvolvimento de novas biotecnologias.
} 
global ser reforçada pela colocação em marcha dessas políticas discriminatórias de integração econômica. Além das políticas comerciais, as desigualdades entre os países e seus agentes econômicos no âmbito da agricultura foram reforçadas pelo estabelecimento do regime internacional de propriedade intelectual (e do recurso das patentes) ${ }^{39}$, que permitiu às corporações transnacionais do agronegócio assegurar o aproveitamento exclusivo de suas invenções tecnológicas. De fato, Otero (2008:16) explica que, uma característica que define o setor de pesquisa e desenvolvimento das biotecnologias, é seu "frenesi por patentes"

Ao garantirem os direitos exclusivos de uso (principalmente, comercial) sobre as novas tecnologias, as patentes se colocaram como um dos principais fatores da consolidação da estrutura corporativa (e altamente oligopolizada) que pauta o ritmo atual da industrialização da agricultura no mundo ${ }^{41}$. Isso porque, o regime internacional de propriedade intelectual se estabeleceu sobre um cenário de profundas desigualdades nacionais, em termos do grau de desenvolvimento dos setores de ciência e tecnologia em cada país. Assim, esse sistema tem se colocado como mais um mecanismo de reforço das assimetrias entre os países e seus agentes econômicos, pois, apenas aqueles países com setores científicos avançados conseguem extrair benefícios do uso exclusivo de suas invenções, reduzindo as demais sociedades a meros consumidores de tecnologias (Otero, $2008,2012)^{42}$.

Assim, tem-se que, apesar da retórica "globalista" disseminada desde os anos 1990, o que se estabeleceu na prática foi um esquema de reforço das

\footnotetext{
${ }^{39}$ Uma patente é a figura legal que atribui direitos de uso exclusivo sobre uma invenção (produto ou processo), por um tempo determinado. Ao ter uma invenção patenteada, o proprietário decide se quer (ou não) outorgar uma licença para o aproveitamento da mesma por terceiros, geralmente, em troca do pagamento de royalties - i.e., de um pagamento pelo direto de uso (WIPO, 2014).

${ }^{40}$ De acordo com o autor, o aumento dos pedidos de obtenção de patentes no setor da biotecnologia nos EUA tem sido frenético, podendo ser constatado no crescimento da fila de espera: enquanto o total de aplicações pendentes passou de 5.837, em 1986, para 6.907 em 1987, o total de pendências acumuladas em 2003 atingiu o número de 500.000 (Otero, 2008:17).

${ }^{41}$ Partindo do esquema proposto por Goodman et. al. (2008) para descrever as especificidades do processo de industrialização da agricultura - conferir nota de rodapé 33 - Pechlaner (2010) sugere que essas práticas de monopolização do uso do conhecimento constituem um novo mecanismo de acumulação no processo agrícola: enquanto o "apropriacionismo" e o "substitucionismo" se referiam às estratégias de acumulação nas esferas da produção e do processamento, o "expropriacionismo" surge na esfera dos mecanismos legais associados ao desenvolvimento das novas tecnologias - que operam no sentido de beneficiar os desenvolvedores dessas inovações, que, dessa forma, passam a controlar, cada vez mais, o ritmo e os padrões da produção agrícola a nível mundial, em prejuízo dos produtores rurais e das necessidades da maioria da população.

${ }^{42}$ Nesse contexto, cabe ressaltar a centralidade das organizações multilaterais para a legitimação e consolidação dos novos esquemas comerciais e de propriedade intelectual, com destaque para a Organização Mundial do Comércio (OMC), que dirige as negociações nesses âmbitos.
} 
assimetrias entre os países, resultando no aprofundamento da vulnerabilidade econômica dos países periféricos, em especial, das nações que abrigam amplos setores agrícolas - como os países da América Latina. A respeito do caráter desses processos, McMichael (2000:141) argumentou que:

\begin{abstract}
A liberalização da agricultura é profundamente simbólica da tentativa de legitimar a integração econômica mundial, justamente porque a identificação histórica da agricultura é com o local e a nação. Enquanto a maior integração transforma todos os estados por meio da liberalização econômica, também reforça as relações globais de poder - neste caso, as relações do imperialismo do agronegócio. Isto é, o que é apresentado como regras universais de comércio (às quais os estados se comprometem individualmente) na verdade serve para fortalecer interesses geopolíticos e corporativos existentes. (Grifos nossos).

(...) Isto não quer dizer que os governos não regulam ou administram, mas o fazem cada vez mais dentro do marco da construção de acordos multilaterais, muitos do quais privilegiam os atores corporativos transnacionais em lugar dos cidadãos e comunidades nacionais. (Tradução própria).
\end{abstract}

Certamente, não se trata de processos que avançam sem contradições. Em anos recentes (notadamente, desde os anos 2000), diversos países - em especial, os chamados "emergentes", como China, Brasil e Índia - têm desafiado cada vez mais essas estruturas assimétricas. Por outro lado, também pode citar-se a proliferação de movimentos sociais e organizações da sociedade civil (tanto a nível nacional, como internacional) que questionam e protestam contra o avanço do modelo da agricultura moderna e de seu marco corporativo ${ }^{43}$.

Enfim, ao analisar as dinâmicas agrárias contemporâneas encontra-se que, a produção e circulação de alimentos e matérias primas agrícolas estão cada vez mais organizadas em nível global, onde os setores mais dinâmicos das diversas economias nacionais e seus mercados consumidores se integram a estruturas globais de produção e distribuição de alimentos e bens agroindustriais. Conforme indicado anteriormente, as firmas transnacionais do agronegócio constituem o núcleo organizador desse modelo, ao controlarem grande parte dos fluxos comerciais mundiais das commodities agrícolas, e dos investimentos no

\footnotetext{
${ }^{43}$ Nesse contexto, destaca-se a formação da "Via Campesina", movimento internacional nascido em 1993 que coordena os esforços de organizações de camponeses, produtores e dos povos indígenas espalhados por diversos países da América Latina, África e Ásia na defesa de seus diretos. Também, ganham relevância movimentos sociais e organizações de alcance nacional. A análise dessas manifestações, porém, foge do escopo do presente trabalho. A respeito desse tema, recomenda-se ver: Piñeiro (2004); Giarraca e Levy (2004); Fernandes (2008); Moyo e Yeros (2008); Niemeyer (2006).
} 
desenvolvimento de novas tecnologias e na ampliação das atividades em geral (Moreira, 2004; Friedland, 2004).

Surgem e se consolidam, assim, as chamadas "cadeias agro-alimentares (ou agroindustriais) globais", referentes a essas estruturas globais que agrupam as diferentes fases do processo de produção agrícola, desde a elaboração e fornecimento de insumos, passando pela produção (cultivo) propriamente dita, até as fases de processamento e distribuição dos produtos finais elaborados (Piñeiro, 1996; 2004).

Nesse esquema (ilustrado na Figura 1) a divisão do trabalho resultante do processo de integração desigual - conforme descrito ao longo deste capítulo pode constatar-se ao ver que os países "em desenvolvimento",44, em geral, se especializam na produção dos cultivos agrícolas, conseguindo, em algumas ocasiões, incorporar também atividades de processamento básico. Por sua parte, os segmentos onde acontece a maior agregação de valor aos produtos, se localizam fora desses países, sendo controlados pelas corporações transnacionais do agronegócio - notadamente, de origem estadunidense ou europeia.

Figura 1 - Cadeia de valor global do agronegócio e as economias em desenvolvimento

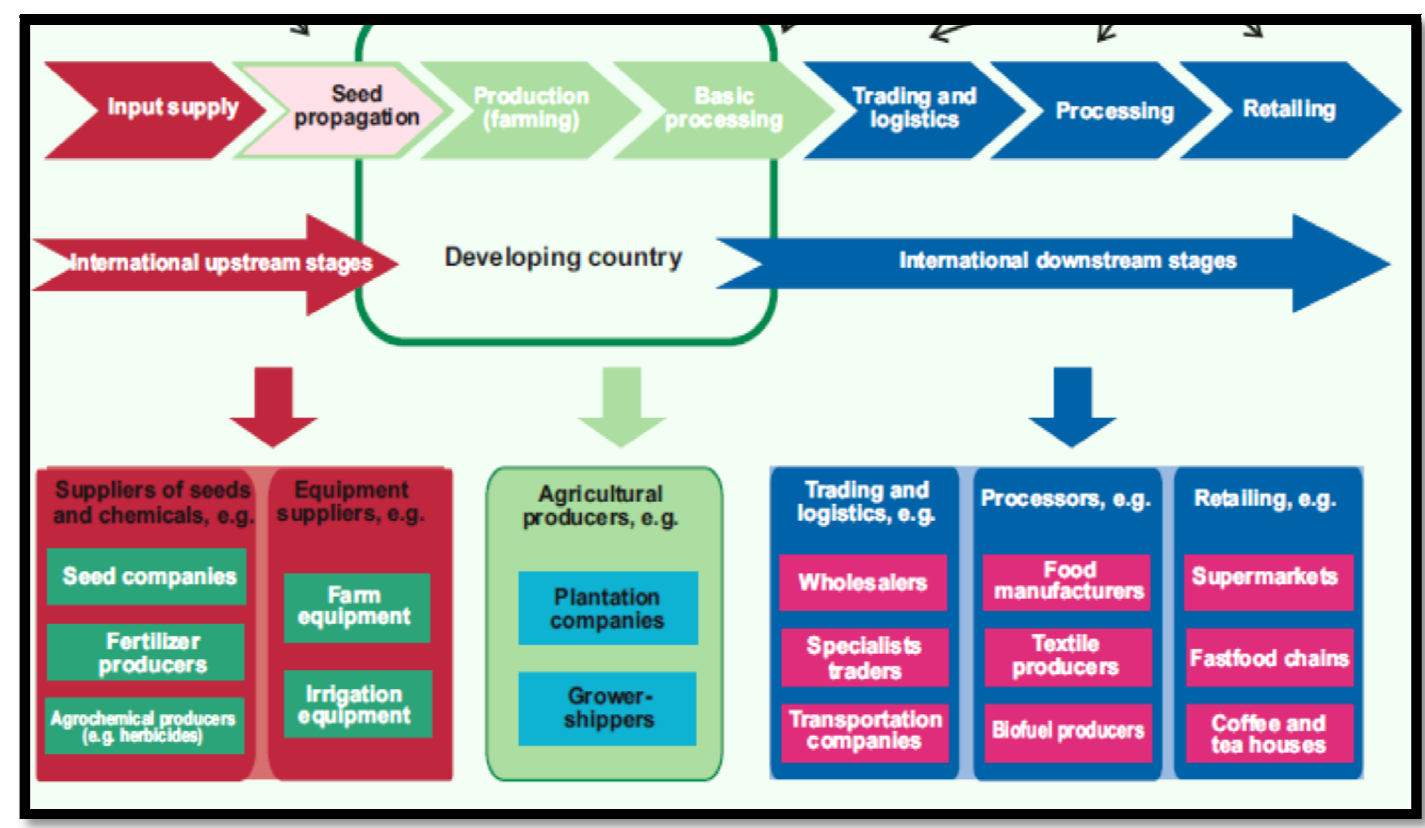

Fonte: Adaptado de UNCTAD (2009:107)

\footnotetext{
${ }^{44}$ Seguindo a denominação utilizada pela UNCTAD (2009).
} 
Com efeito, ao analisar os fluxos globais de investimentos estrangeiros dirigidos ao conjunto das atividades da cadeia global agro-alimentar, a UNCTAD (2009) verificou que os investimentos originados nos países em desenvolvimento têm uma participação relativamente maior no segmento da produção, enquanto os demais processos permanecem fortemente controlados por firmas de países desenvolvidos ${ }^{45}$. Entende-se, assim, a marcada orientação das economias em desenvolvimento - em especial, dos países da América Latina - para o padrão de desenvolvimento agroexportador.

Apesar da persistência do padrão de oligopolização do sistema agroalimentar global pelas economias desenvolvidas e seus agentes econômicos nas últimas décadas, também é preciso apontar que têm se vislumbrado alguns espaços onde os países em desenvolvimento conseguem uma maior participação nessa estrutura, seja incorporando um maior número de atividades das cadeias globais em seus territórios, atraindo maiores fluxos de investimentos, ou apoiando a ascensão internacional de empresas locais. O Brasil se coloca como um importante exemplo desse fenômeno, a partir dos avanços no seu setor de biocombustíveis (especialmente, na produção de etanol) e do surgimento de transnacionais brasileiras no setor, como a JBS-Friboi ${ }^{46}$.

A ascensão de países como Brasil ou China no âmbito do agronegócio parece se colocar como um desafio para essas estruturas tradicionalmente dominadas pelas economias dos Estados Unidos, e de alguns países europeus. Todavia, conforme exposto ao longo do capítulo (e também a ser visto no próximo), a maior parte dos investimentos globais em agricultura ainda se origina nos países centrais, evidenciando seu amplo controle sobre o modelo como um todo e, em especial, sobre os segmentos considerados estratégicos. Além disso, diversos analistas, como Wilkinson (2009), apontam que essa tendência de ascensão estaria se configurando sob as mesmas lógicas que, no final, levam a uma maior polarização social (no nível nacional) e oligopolização do sistema (no nível mundial), mudando apenas a origem ou localização geográfica desses nós -

\footnotetext{
${ }^{45}$ A análise dos fluxos de investimentos globais em agricultura, e de outros aspectos relacionados ao funcionamento das cadeias, é realizada em maior profundidade no próximo capítulo.

${ }^{46} \mathrm{O}$ caso do despontamento do Brasil no âmbito do agronegócio é analisado em maior profundidade no próximo capítulo, com o intuito de apontar as principais implicações desse processo de diferenciação para as dinâmicas de integração regional e de desenvolvimento agrário dos demais países da região - particularmente, do Paraguai.
} 
isto é, de quem passa a controlar esses oligopólios - não representando uma grande mudança para os pequenos produtores ou para a população em geral.

\section{3}

\section{O fenômeno do landgrabbing}

As tendências de concentração verificadas ao longo do sistema agroalimentar global - especialmente, nos segmentos de elaboração de insumos e de processamento e distribuição - também têm se refletido nas dinâmicas em torno do uso e apropriação da terra. Ao longo do processo de modernização da agricultura nas diferentes sociedades, as atividades de produção (cultivo ou criação de animais), em geral, permaneceram sob o comando de atores locais (à diferença dos demais segmentos da cadeia, que se tornaram mais “internacionalizados”). Isso não significa que as tendências de concentração no uso e na propriedade da terra não tenham acontecido. Porém, o que tem chamado a atenção dos políticos, ativistas e acadêmicos, nos últimos anos, é a proliferação de operações comerciais envolvendo grandes superfícies de terra e volumes de capital ao redor do mundo, principalmente, nos continentes dotados com vastas extensões desse recurso aptas para a atividade agrária - como na África e na América Latina. Isto é, tem-se verificado um maior envolvimento de capitais e agentes estrangeiros nas dinâmicas locais de concentração da terra. Esse fenômeno tem sido denominado como "landgrabbing" (ou "estrangeirização").

De acordo com Borras et. al. (2012), a dinamização do mercado de terras em nível global está acontecendo em função da convergência de "múltiplas crises": a crise de alimentos, provocada pelo contínuo aumento da demanda ${ }^{47}$; a crise energética e climática, que tem levado a busca de fontes alternativas de energia, mais baratas e menos poluentes (como parecem ser os biocombustíveis); e a crise financeira, que desde 2008 tem levado o capital financeiro a procurar novas oportunidades mais seguras de investimentos. Ou seja, a convergência

\footnotetext{
${ }^{47}$ Cabe apontar que, o aumento da demanda por alimentos não se refere apenas a um crescimento da população mundial - como comumente se argumenta - mas também à crescente adoção de uma dieta centrada em alimentos a base de trigo, carne e lácteos - em lugar de grãos e cereais locais que acompanha o estabelecimento dos padrões de produção da agricultura moderna nas economias em desenvolvimento (Otero e Pechlaner, 2008). A sustentação dessa dieta resulta em maiores pressões sociais e ambientais sobre a utilização da terra, na medida em que a criação de animais prescinde de grandes extensões de terra, além de grandes volumes de ração animal - que, por sua vez, ao ser elaborado a partir da soja (principalmente), compete com a produção de outros bens a base de soja, contribuindo também para o aumento da demanda por esse cultivo.
} 
dessas crises tem resultado no acirramento da corrida pelos recursos que assegurem o atendimento dessas demandas, essencialmente, da terra ${ }^{48}$.

Embora rememorem as históricas corridas por novos territórios, da época do colonialismo ou da era do imperialismo do final do século XIX especialmente, pela forte tendência "norte-sul" que o atravessa - o fenômeno atual ganha características particulares em função de aspectos como: a diversidade de atores envolvidos na apropriação (de empresas locais e transnacionais, e de governos nacionais, tanto dos países desenvolvidos como de países em desenvolvimento); as diferentes formas de apropriação da terra e recursos associados (como a água) seja pela compra direta, aluguel de territórios ou por meio de contratos de fornecimento de bens agrícolas; e a junção das múltiplas crises. Com efeito, a identificação dessas especificidades levaram Borras et. al. (2012) a advogar por uma concepção mais ampla do fenômeno e da própria definição do landgrabbing que, geralmente, focaliza apenas os casos de aquisição de grandes superfícies de terra para a produção de alimentos - enquanto que, na realidade, verificam-se diversas formas de apropriação e uso em andamento.

Um estudo da FAO (2012) a respeito da extensão da dinâmica de concentração e estrangeirização de terras nos países da América Latina, por exemplo, se utilizou de uma definição de landgrabbing centrada na questão da crise alimentar e nos volumes de terra envolvidos, para a realização de suas análises. Ou seja, determinou que o fenômeno se verificava (apenas) nos casos onde havia o envolvimento de grandes superfícies de terras, a participação dos Estados, e a colocação em marcha de impactos negativos para a segurança alimentar, isto é, para a produção de alimentos para o consumo interno. Dessa forma, o estudo chegou à conclusão de que apenas em dois países da região Brasil e Argentina - era possível falar em landgrabbing.

Estudando as limitações da definição utilizada - que também se repete em outros diversos estudos sobre o tema - Borras et. al. (2012:851) propõem a utilização de uma definição mais ampla, que dê conta das particularidades atuais mencionadas anteriormente:

\footnotetext{
${ }^{48}$ Um desdobramento disso tem sido o desenvolvimento dos cultivos "flexíveis" ("flex crops"), que têm usos diversos - seja como alimentos, ou como base para a elaboração de ração animal, biocombustíveis, e outros produtos industriais - e que podem ser intercambiados facilmente. Alguns dos principais cultivos flexíveis são: a soja (alimento, ração animal, e biocombustível); a cana de açúcar (alimento e biocombustível); o milho (alimento, ração animal e biocombustível); etc. (Borras, et. al. 2012).
} 
Em suma, o landgrabbing atual é a captura do controle de extensões relativamente vastas de terra e outros recursos naturais ["control grabbing"] por meio de uma variedade de mecanismos e formas que envolvem grandes volumes de capitais que frequentemente mudam a orientação do uso dos recursos para um caráter extrativo, seja para propósitos internacionais ou domésticos, como uma resposta do capital à convergência das crises alimentaria, energética e financeira, para os imperativos de mitigação da mudança climática, e para as demandas por recursos dos novos subcentros do capital global (Tradução própria. Grifos nossos).

Analisando os mesmos dados coletados pela FAO (2012) através dessa nova lente conceitual, os autores concluíram que pelo menos dez países da região sofrem atualmente com o fenômeno da "estrangeirização" em grau significativo ${ }^{49}$. Além disso, os autores identificaram que as dinâmicas de concentração e de estrangeirização da terra nos países da América Latina e do Caribe adotam um caráter "intra-regional", ao serem impulsionadas, em grande medida, por investimentos oriundos da própria região.

Enquanto maiores detalhes a respeito das dinâmicas de estrangeirização nos países da América Latina são apresentados no próximo capítulo, cabe ressaltar aqui a importância de considerar as tendências em torno do uso e apropriação da terra que, embora se insiram em um segmento (da produção agrícola, propriamente dita) onde o valor agregado aos bens produzidos é relativamente menor, e onde as transnacionais do agronegócio, em geral, destinam menos investimentos (à diferença de outros segmentos das cadeias agro-alimentares globais), representa um recurso estratégico. Com feito, para além das divergências conceptuais a respeito da definição do fenômeno, os estudos sobre o tema têm coincidido em apontar para uma crescente dinamização do mercado de terras, sobretudo, nos países "do sul global", levantando preocupações a respeito dos impactos desses processos para as tendências de polarização social e degradação ambiental que, conforme exposto antes, são mais graves nessas sociedades.

\section{4 \\ O imperialismo do agronegócio}

A partir das considerações apresentadas no presente capítulo, tem-se que o processo de desenvolvimento e expansão do modelo da agricultura moderna (ou

\footnotetext{
${ }^{49}$ Argentina, Bolívia, Brasil, Chile, Colômbia, Equador, Guatemala, Paraguai, Peru e Uruguai. Ao passo que outros três países o experimentam menos intensamente: México, Panamá e Nicarágua.
} 
do agronegócio) se rege, essencialmente, pela lógica da acumulação capitalista, isto é, pela busca incessante de aumento da lucratividade. Sendo assim, esses processos respondem, acima de tudo, aos interesses das grandes corporações transnacionais e demais agentes econômicos associados na difusão do modelo, enquanto as necessidades da maioria da população mundial e do meio ambiente permanecem em segundo plano. Nesse contexto, entende-se que, a persistência das problemáticas da pobreza e da fome no mundo, mais do que resultar de uma deficiência na produção mundial de alimentos, diz respeito a uma má distribuição dos benefícios gerados pelos avanços tecnológicos na área.

O desenvolvimento e a expansão mundial do agronegócio se desdobram, atualmente, em um contexto de aprofundamento da integração econômica dos países aos mercados mundiais e de crescente oligopolização das esferas estratégicas do modelo (como o de pesquisa e desenvolvimento de novas tecnologias agrícolas) por agentes oriundos das economias centrais (ou “desenvolvidas"), notavelmente, dos Estados Unidos. Por outro lado, tem se verificado uma participação cada vez maior de capitais e agentes econômicos patrocinados pelos países "em desenvolvimento" na dinâmica de desenvolvimento da agricultura a nível mundial - com destaque para o Brasil na região da América do Sul - embora isso não esteja (ainda) constituindo uma ameaça para os oligopólios das grandes firmas transnacionais do setor, ou representando uma ruptura com a lógica do modelo vigente.

Ao longo do capítulo, percebeu-se que a agricultura constitui um eixo central da expansão do capitalismo e da definição das relações imperialistas e de dependência. A consideração dos acontecimentos políticos e econômicos específicos desse âmbito serviu para aprofundar a compreensão sobre essas relações, especialmente, sobre a situação dos países da América Latina, onde as atividades agrícolas ocuparam sempre um lugar de destaque. Verificou-se que a agricultura não consiste simplesmente nas atividades relacionadas o cultivo, mas envolve um conjunto de processos que se estendem desde a elaboração e fornecimento de insumos agrícolas (sementes, agroquímicos e máquinas), até o processamento e a distribuição ao consumidor final (de alimentos ou outros produtos agroindustriais). Da mesma forma, constatou-se que a agricultura não é uma atividade própria dos países dependentes (ou periféricos), indicando a 
existência de dinâmicas mais complexas, e a necessidade de ampliar a compreensão do esquema da divisão internacional do trabalho.

Com base nas análises apresentadas, tem-se que essa estrutura não se limita apenas ao aspecto da especialização dos países na produção de determinados bens (agrícolas ou manufaturados), mas envolve também a questão de como se produz e para quem - isto é, qual é o padrão de produção, e quem se beneficia ou controla os resultados obtidos com a atividade.

Tais considerações se colocam como complemento das reflexões realizadas no capítulo anterior a partir das teorias da dependência, que, embora tenham admitido a expansão generalizada do capital industrial estrangeiro (inclusive na agricultura) nos países da América Latina, os impactos nessa esfera específica não fizeram parte de sua agenda de pesquisa. Assim, o presente capítulo completa a base teórico-conceitual a partir da qual se buscará compreender as tendências atuais do agronegócio no mundo e na América Latina $\mathrm{e}$, particularmente, as características do desenvolvimento desse modelo no Brasil e no Paraguai. 
4.

\section{A expansão do agronegócio no Cone Sul: integração imperialista e desenvolvimento desigual}

Atualmente, a atividade agrícola dos países da América Latina se encontra amplamente organizada em função de cadeias globais de produção e comercialização, que se orientam para o atendimento das demandas por matériasprimas agrícolas, alimentos e outros produtos agroindustriais a nível mundial. Nas últimas décadas, a ampliação dessas cadeias se acelerou na região, particularmente, nos países do Cone Sul, que emergem como importantes fornecedores de commodities agrícolas (especialmente, de soja). De fato, o crescimento massivo desse cultivo nos últimos anos colocou os países da região como principais produtores e exportadores mundiais de soja.

O processamento e a comercialização dos bens agrícolas produzidos no Cone Sul, entretanto, são vastamente controlados por grandes empresas transnacionais do agronegócio, implicando uma marcada subordinação das estruturas produtivas e atores locais desses países à sua lógica de atuação. Nesse sentido, tem-se que, a ampliação das cadeias agroindustriais (ou agro-alimentares) globais nos países da região caracteriza um processo de integração econômica subordinada ao capital internacional - ou, um processo de "integração imperialista", seguindo as reflexões apresentadas no capítulo teórico.

Por outro lado, verifica-se que, esse processo de integração adquire desdobramentos específicos de acordo com a sociedade em foco. No caso do Paraguai, por exemplo, tem-se que, além de sua produção estar organizada em função das cadeias comandadas pelas firmas transnacionais, a estrutura produtiva do país abriga um importante grupo de capitais e empresários de origem brasileira, que controla uma importante parcela da dinâmica de produção local. Essa situação indica que o processo de integração desses países à cadeia global agroindustrial - assim como o grau de desenvolvimento do modelo do agronegócio em seus respectivos territórios - acontece de forma desigual, sugerindo o estabelecimento de um padrão de "divisão regional do trabalho" nesse contexto. 
O presente capítulo tem por objetivo ensaiar essa hipótese, estudando a configuração atual das cadeias agroindustriais globais e as características de sua ampliação na região da América Latina nos últimos anos, em especial, nos países do Cone Sul. Na análise, procura-se apontar para as evidências de diferenciação "intra-regional” decorrentes desse processo que, a primeira vista, coloca os países em questão em uma situação similar de subordinação. Examinam-se dados como o comportamento recente dos fluxos globais de IED orientados para a agricultura e das parcelas desses fluxos que se destinam para a região da América Latina, particularmente, para os países do Cone Sul. Também, investigam-se as tendências em torno dos diferentes segmentos da cadeia global de produção agrícola instalados na região, especialmente, da cadeia de produção da soja. Essas análises, também, levam em conta as informações sobre os perfis agrárioeconômicos dos países em foco, a fim de inferir o impacto desses processos nas suas respectivas dinâmicas socioeconômicas.

Considerando que a posição atual do Brasil na dinâmica de integração global dos mercados agro-alimentares destoa significativamente da situação dos demais países da região, uma seção do presente capítulo é dedicada, exclusivamente, a uma breve revisão do processo de desenvolvimento da agricultura moderna no país nas últimas décadas. Nessa seção, busca-se ampliar a compreensão dos fatores que impulsionaram a ascensão do agronegócio brasileiro e, particularmente, a expansão de suas forças econômicas para outros territórios, como o Paraguai. O maior desenvolvimento relativo do setor agroindustrial brasileiro é comumente considerado como pano de fundo do surgimento desse fenômeno.

No final, argumenta-se que, com base nas evidências encontradas é possível falar do estabelecimento de uma "divisão regional do trabalho" entre os países do Cone Sul no âmbito de sua integração à dinâmica global do agronegócio, sendo liderada pelo Brasil, mas, subordinando-se como um todo às determinações do esquema mais amplo de divisão internacional do trabalho, comandado pelas firmas transnacionais do setor. Dessa forma, começa-se a compreender as principais causas e modalidades da participação brasileira na dinâmica do agronegócio no Paraguai, que serão analisadas em maior detalhe no último capítulo. 


\section{1 \\ As cadeias agro-alimentares globais na América Latina}

Nos dias atuais, a dinâmica agrária da maior parte dos países mundo, e em especial dos países da América Latina, se encontra amplamente organizada em função das "cadeias agro-alimentares (ou agroindustriais) globais". Isto é, os sistemas produtivos agrários dos países latino-americanos estão cada vez mais integrados e sujeitos aos padrões e demandas dos mercados internacionais, fazendo parte de uma série de processos interligados que superam a mera atividade da produção (i.e. cultivo) de bens agrícolas.

Resumidamente, as cadeias agro-alimentares (ou agroindustriais) representam estruturas produtivas organizadas em nível global, que agrupam as diferentes instâncias do processo de produção e circulação mundial de matériasprimas agrícolas, alimentos e outros produtos agroindustriais, estendendo-se desde o fornecimento de insumos para a produção, até a comercialização para o consumidor final (Piñeiro, 1996; 2004).

Nessa estrutura, as corporações transnacionais - de origem predominantemente europeia e estadunidense - se colocam como o núcleo organizador do modelo, uma vez que têm uma ampla participação nos mercados mundiais, concentrando suas atividades e investimentos nos segmentos estratégicos dessas cadeias: no desenvolvimento e fornecimento de insumos para a produção (sementes, agroquímicos, e maquinário), na logística de coleta, armazenamento e comercialização (exportação) da produção primária, na industrialização das matérias-primas agrícolas, e na comercialização de produtos finais elaborados. Com efeito, amiúde se afirma que as firmas transnacionais assumem o controle sobre o que e o como será produzido em nível mundial.

A organização da estrutura de produção agrícola e agroindustrial em nível global, assim como a lógica de atuação das corporações transnacionais, podem ser verificadas na Tabela 1, que apresenta uma classificação das maiores empresas em cada segmento da cadeia global do agronegócio. Nesse esquema, elaborado pela UNCTAD (2009), os diferentes segmentos são separados em dois grandes grupos: as atividades relacionadas à agricultura ("agricultural-related"), que correspondem às quatro últimas colunas; e as atividades de base agrícola (“agricultural-based”), referentes à produção em si (primeira coluna do quadro). 
Tabela 1 - As dez maiores firmas transnacionais da cadeia global do agronegócio em 2007

\begin{tabular}{|c|c|c|c|c|c|}
\hline N. & Produção & $\begin{array}{l}\text { Fornecedores de } \\
\text { insumos }\end{array}$ & \begin{tabular}{|c|}
$\begin{array}{c}\text { Fabricantes } \\
\text { de alimentos e } \\
\text { bebidas }\end{array}$ \\
\end{tabular} & Varejistas & \begin{tabular}{|c|} 
Outras (de \\
propriedade \\
privada)
\end{tabular} \\
\hline 1 & $\begin{array}{l}\text { Sime Darby Bhd. } \\
\text { (Malasia) }\end{array}$ & \begin{tabular}{|l} 
BASF \\
(Alemanha)
\end{tabular} & $\begin{array}{|ll|}\begin{array}{l}\text { Nestlé } \\
\text { (Suíza) }\end{array} & \text { SA } \\
\end{array}$ & $\begin{array}{l}\text { Wal-Mart Stores } \\
\text { (EUA) }\end{array}$ & $\begin{array}{ll}\text { Cargill Inc. } \\
\text { (EUA) }\end{array}$ \\
\hline 2 & $\begin{array}{l}\text { Dole Food Company, } \\
\text { Inc. (EUA) }\end{array}$ & $\begin{array}{l}\begin{array}{l}\text { Bayer } \\
\text { (Alemanha) }\end{array} \\
\end{array}$ & $\begin{array}{|ll|}\text { Inbev } & \text { SA } \\
\text { (Holanda) }\end{array}$ & $\begin{array}{l}\text { Metro AG } \\
\text { (Alemanha) }\end{array}$ & Mars Inc. (EUA) \\
\hline 3 & $\begin{array}{l}\text { Fresh Del Monte } \\
\text { Produce (EUA) }\end{array}$ & $\begin{array}{l}\text { Dow Chemical } \\
\text { Company (EUA) }\end{array}$ & 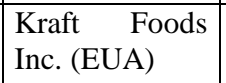 & $\begin{array}{ll}\begin{array}{l}\text { Carrefour } \\
\text { (França) }\end{array} & \text { SA } \\
\end{array}$ & Lactails (França) \\
\hline 4 & $\begin{array}{ll}\begin{array}{l}\text { Socfinal } \\
\text { (Luxemburgo) }\end{array} & \text { SA }\end{array}$ & $\begin{array}{l}\text { Deere \& Company } \\
\text { (EUA) }\end{array}$ & $\begin{array}{l}\text { Unilever } \\
\text { (UK/Holanda) }\end{array}$ & $\begin{array}{l}\text { Tesco } \\
\text { (UK) }\end{array}$ & $\begin{array}{l}\begin{array}{l}\text { Suntory Ltd. } \\
\text { (Japão) }\end{array} \\
\end{array}$ \\
\hline 5 & $\begin{array}{lr}\text { Charoen } & \text { Pokphand } \\
\text { Foods } & \text { Public } \\
\text { Company } & \text { Ltd. } \\
\text { (Tailândia) } & \\
\end{array}$ & 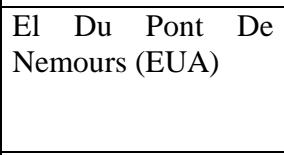 & $\begin{array}{l}\text { Coca-Cola } \\
\text { Company } \\
\text { (EUA) }\end{array}$ & $\begin{array}{l}\text { McDonalds } \\
\text { Corp. (EUA) }\end{array}$ & $\begin{array}{lr}\text { Dr. } & \text { August } \\
\text { Oetker } & \text { KG } \\
\text { (Alemanha) } & \end{array}$ \\
\hline 6 & $\begin{array}{lr}\text { Chiquita } & \text { Brands } \\
\text { International, } & \text { Inc. } \\
\text { (EUA) } & \end{array}$ & $\begin{array}{l}\text { Syngenta } \\
\text { (Suíza) }\end{array}$ & $\begin{array}{|ll|}\begin{array}{l}\text { SAB } \\
\text { (UK) }\end{array} & \text { Miller } \\
\end{array}$ & $\begin{array}{l}\text { Delhaize Group } \\
\text { (Bélgica) }\end{array}$ & $\begin{array}{l}\text { Louis Dreyfus } \\
\text { Group (França) }\end{array}$ \\
\hline 7 & $\begin{array}{|lr|}\text { Kuala } & \text { Lumpur } \\
\text { Kepong } & \text { Bhd. } \\
\text { (Malasia) } & \\
\end{array}$ & $\begin{array}{l}\text { Yara International } \\
\text { ASA (Noruega) }\end{array}$ & $\begin{array}{|ll|}\begin{array}{l}\text { Diageo } \\
(\mathrm{UK})\end{array} & \text { PLC } \\
\end{array}$ & \begin{tabular}{|ll}
$\begin{array}{l}\text { Koninklijke } \\
\text { Ahold } \\
\text { (Holanda) }\end{array}$ & $\mathrm{NV}$ \\
\end{tabular} & Barilla (Italia) \\
\hline 8 & \begin{tabular}{|ll}
$\begin{array}{l}\text { KWS Saat } \\
\text { (Alemanha) }\end{array}$ & AG
\end{tabular} & $\begin{array}{l}\text { Potash Corp. of } \\
\text { Saskatchewan } \\
\text { (Canadá) }\end{array}$ & $\begin{array}{l}\text { Pemod Ricard } \\
\text { SA (França) }\end{array}$ & Sodexo (França) & Ferrero (Italia) \\
\hline 9 & $\begin{array}{l}\text { Kulim (Malasia) Bhd. } \\
\text { (Malasia) }\end{array}$ & $\begin{array}{l}\text { Kubota } \\
\text { (Japão) }\end{array}$ & \begin{tabular}{|l|}
$\begin{array}{l}\text { Cadbury } \\
\text { (UK) }\end{array}$ \\
\end{tabular} & $\begin{array}{l}\text { Compass Group } \\
\text { PLC (UK) }\end{array}$ & $\begin{array}{l}\text { Keystone Foods } \\
\text { LLC (EUA) }\end{array}$ \\
\hline 10 & Camellia PLC (UK) & $\begin{array}{l}\text { Monsanto Company } \\
\text { (EUA) }\end{array}$ & $\begin{array}{l}\text { Bunge Limited } \\
\text { (EUA) }\end{array}$ & $\begin{array}{l}\text { Seven \& } \quad \text { I } \\
\begin{array}{l}\text { Holdings } \\
\text { Company } \\
\text { (Japão) }\end{array} \\
\end{array}$ & $\begin{array}{l}\text { McCain Foods } \\
\text { Ltd. (Canada) }\end{array}$ \\
\hline \multicolumn{6}{|c|}{$\begin{array}{l}\text { Obs1: Muitas das firmas listadas têm atuação em mais de um segmento da cadeia. No quadro, são } \\
\text { apresentadas apenas em um grupo, sendo classificadas conforme a sua atividade principal. }\end{array}$} \\
\hline & 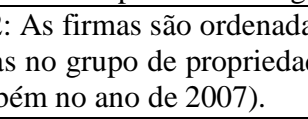 & 15 & 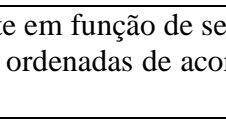 & $x_{1}$ & iros, a exceção das \\
\hline
\end{tabular}

Fonte: Adaptado de World Investment Report 2009 (UNCTAD, 2009:124; 239-242) ${ }^{50}$

Com base nos dados da Tabela 1, constata-se que as corporações transnacionais oriundas de países "desenvolvidos" - seguindo a denominação da UNCTAD (2009) - são dominantes nos segmentos relacionados à produção agrícola, que são as atividades consideradas estratégicas da cadeia e, em geral, de maior rentabilidade. Já no segmento da produção agrícola propriamente dita, também se verifica a atuação de grandes empresas, porém, com uma maior participação de empresas oriundas de países "em desenvolvimento",51. De fato, ao analisar os fluxos globais de IED dirigidos ao conjunto das atividades da cadeia

\footnotetext{
${ }^{50}$ A UNCTAD publica anualmente o "World Investment Report (WIR)", documento que expõe as tendências mais recentes do IED global. A cada edição, o documento também traz análises de tópicos específicos sobre IED e desenvolvimento. O WIR de 2009 foi dedicado à questão da agricultura e, por isso, constitui uma referência central no presente trabalho.

${ }^{51} \mathrm{Na}$ tabela apresentada, seria o caso das três firmas oriundas da Malásia e de uma da Tailândia.
} 
do agronegócio, a UNCTAD (2009) indica que os investimentos originados nos países em desenvolvimento têm uma participação relativamente maior no segmento da produção, enquanto os investimentos nos demais segmentos são controlados por firmas de países desenvolvidos.

Um segmento onde se verifica esse forte controle é no de fornecimento de insumos para a produção. Conforme apontado no capítulo anterior, a elaboração de insumos para a produção agrária constitui um segmento estratégico por excelência, na medida em que se trata do setor responsável pelo desenvolvimento de inovações técnicas e tecnológicas a serem utilizadas na produção agropecuária. Em outras palavras, refere-se ao setor que define, em grande medida, os rumos da produção agrícola. Ao mesmo tempo, é um segmento fortemente beneficiado pelo sistema de patentes, que lhe assegura alta lucratividade.

No mercado global de sementes, por exemplo, as informações do Grupo ETC $^{52}$ apontaram que, em 2011, as dez maiores empresas fornecedoras de sementes de marcas próprias detinham em conjunto uma parcela de 75,3\%. Já as dez maiores empresas que atuavam no mercado mundial de agroquímicos no mesmo ano (elaborando produtos para a "proteção de cultivos", como inseticidas, herbicidas e fungicidas), detinham uma parcela de 94,5\% (ETC Group, 2013) ${ }^{53}$. Por outro lado, essa tendência de concentração dos mercados nas mãos de poucas empresas se agrava ao considerar-se que várias dessas firmas atuam em mais de um segmento. No caso do fornecimento de insumos, por exemplo, tem-se que a primeira colocada em vendas globais de sementes em 2011 (com uma parcela de 26\% do mercado) foi a empresa estadunidense Monsanto, que também teve uma colocação importante no ranking mundial de venda de agroquímicos: colocou-se no quinto lugar, com uma parcela de $7,4 \%$ do mercado global ${ }^{54}$.

52 O Grupo ETC - "Action Group on Erosion, Technology and Concentration" - é uma organização internacional voltada à pesquisa sobre questões socioeconômicas e ecológicas relacionadas ao desenvolvimento de biotecnologia. Além de trabalhar de perto com organizações da sociedade civil nos diversos continentes, contribuindo para o debate sobre esses temas, o grupo tem status de consultor junto a importantes instituições multilaterais - como a FAO e a UNCTAD. Mais informações sobre o grupo em: http://www.etcgroup.org. Acesso em: 18/05/2014.

${ }^{53}$ Esses dados, por sua vez, constataram o aprofundamento dessas tendências de concentração, pois, os registros realizados para o ano de 2007 apontavam que as dez maiores empresas produtoras de sementes detinham uma parcela de $67 \%$ do mercado global, ao passo que as dez maiores empresas do setor de agroquímicos detinham uma parcela de $89 \%$ do mercado mundial (ETC Group, 2008:4).

${ }^{54}$ Nessa mesma linha, a empresa estadunidense Dupont, colocou-se no segundo lugar no ranking de vendas globais de sementes (com uma parcela de 18,2\% do mercado) e em sexto lugar nas vendas globais de agroquímicos $(6,6 \%)$; a firma suíça Syngenta, se colocou em terceiro lugar 
Outro segmento da cadeia global de produção agrícola e agroindustrial que merece destaque é o de coleta e comercialização das matérias-primas agrícolas ${ }^{55}$. Nesse segmento, também se verifica um alto grau de concentração das atividades nas mãos de (poucas) firmas transnacionais, que atuam como ponte entre a produção dos bens agrícolas nos diferentes locais ao redor do mundo e a demanda da agroindústria global, realizando operações de coleta, armazenagem, processamento inicial e comercialização das matérias primas agrícolas. Dessa forma, essas empresas exercem uma forte influência na fase da produção, especialmente, através dos esquemas de compra dos cultivos que estabelecem com os produtores locais (UNCTAD, 2009).

$\mathrm{Na}$ Tabela 2 apresenta-se um ranking das maiores empresas desse segmento de trading. As três primeiras firmas - Cargill, ADM e Bunge, de origem estadunidense - controlam grande parte do comércio mundial de grãos, marcando uma presença importante em regiões como a do Cone Sul, uma vez que os países dessa região se colocam como importantes produtores de commodities agrícolas.

Tabela 2 - As onze maiores firmas transnacionais processadoras/comerciantes de sementes oleaginosas, grãos e/ou açúcar em 2009

\begin{tabular}{|l|l|}
\hline Empresa e origem (matriz) & $\begin{array}{l}\text { Receita em milhões } \\
\text { de US\$ (2009) }\end{array}$ \\
\hline 1. Cargill (EUA) & 116.600 \\
\hline 2. ADM (EUA) & 69.207 \\
\hline 3. Bunge Ltd. (EUA) & 41.926 \\
\hline 4. Marubeni (Japão) & 39.839 \\
\hline 5. Itochu Intl. (Japão) & 34.191 \\
\hline 6. Louis Dreyfus Commodities (LDC) (França) & 34.000 \\
\hline 7. The Noble Group (China) & 31.183 \\
\hline 8. China Nationals Cereals, Oils and Foodstuffs (China) & 26.445 \\
\hline 9. Wilmar International Ltd. (Singapura) & 23.885 \\
\hline 10. British Foods (UK) & 15.354 \\
\hline 11. ConAgra Foods (EUA) & 13.808 \\
\hline Total & $\mathbf{4 4 6 . 4 3 8}$ \\
\hline
\end{tabular}

Fonte: ETC Group (2011:32)

como fornecedora de sementes $(9,2 \%)$, e em primeiro lugar como fornecedora de agroquímicos $(23,1 \%)$; já a firma alemã Bayer Cropscience, foi segunda no ranking de vendas globais de agroquímicos $(17,1 \%)$, e sétima como fornecedora de sementes $(3,3 \%)$ (ETC Group, 2013). As listas completas podem ser encontradas na seção Anexo, nas Figuras 13 e 14.

55 Esse segmento não aparece de forma separada no esquema elaborado pela UNCTAD (apresentado anteriormente na Tabela 1) - por conta de uma questão metodológica. Mas a sua relevância e das firmas que se inserem nesse ramo não deixam de ser discutidas no relatório da UNCTAD (2009:126), sendo denominado como o segmento das comerciantes ("traders") e das atacadistas ( "wholesalers"), e fazendo parte do grupo das atividades relacionadas à agricultura. 
Nos últimos anos, os investimentos globais em agricultura e nas atividades relacionadas têm aumentado significativamente (CEPAL, 2013; FAO, 2013a; UNCTAD, 2009). O comportamento desses fluxos nos indicam os padrões de ampliação das cadeias agro-alimentares globais e, nesse sentido, algumas das principais tendências a esse respeito são apresentadas a seguir.

A maior parte dos investimentos globais em agricultura nos últimos anos se orientou para as atividades da agroindústria, e para os países desenvolvidos, sugerindo que grande parte dos processos que geram maior valor agregado na cadeia agro-alimentar global ainda está fortemente concentrada nesse grupo de países (UNCTAD, 2009) ${ }^{56}$. Por outro lado, a parcela de IED voltada para o setor primário desses países perdeu peso relativo ao longo desses anos - passando de representar $91 \%$ para $52 \%$ dos fluxos totais - devido a que os países em desenvolvimento começaram a atrair esses fluxos cada vez mais (CEPAL, 2013:106). Na Tabela 3 e na Figura 2, é possível apreciar o comportamento geral desses fluxos nos últimos anos ${ }^{57}$.

Tabela 3 - Fluxos estimados de IED (inward) para a agricultura e agroindústria Em bilhões de dólares e percentagem*

\begin{tabular}{|l|c|c|c|c|}
\hline \multirow{2}{*}{ Grupo } & \multicolumn{2}{c|}{$\begin{array}{c}\text { Agricultura (setor } \\
\text { primário) }\end{array}$} & \multicolumn{2}{c|}{$\begin{array}{c}\text { Agroindústria } \\
\text { (alimentos e bebidas) }\end{array}$} \\
\cline { 2 - 5 } & $\mathbf{1 9 8 9 - 1 9 9 1}$ & $\mathbf{2 0 0 5 - 2 0 0 7}$ & $\mathbf{1 9 8 9 - 1 9 9 1}$ & $\mathbf{2 0 0 5 - 2 0 0 7}$ \\
\hline \multirow{2}{*}{ IED (inward) Mundial } & $\mathbf{0 , 6}$ & $\mathbf{3 , 3}$ & $\mathbf{7 , 2}$ & $\mathbf{4 0 , 5}$ \\
\cline { 2 - 5 } & $0,3 \%$ & $0,2 \%$ & $3,8 \%$ & $2,8 \%$ \\
\hline \multirow{2}{*}{ Economias desenvolvidas } & $\mathbf{- 0}$ & $\mathbf{0}$ & $\mathbf{4 , 8}$ & $\mathbf{3 4 , 1}$ \\
\cline { 2 - 5 } & $\mathbf{( \ldots )}$ & $\mathbf{( \ldots )}$ & $3,2 \%$ & $3,2 \%$ \\
\hline \multirow{2}{*}{ Economias em desenvolvimento } & $\mathbf{0 , 6}$ & $\mathbf{3}$ & $\mathbf{2 , 4}$ & $\mathbf{5 , 1}$ \\
\cline { 2 - 5 } & $1,8 \%$ & $0,8 \%$ & $6,8 \%$ & $1,4 \%$ \\
\hline
\end{tabular}

* As percentagens indicadas se referem às parcelas que esses fluxos representam com relação aos fluxos totais de IED recebidos pelo grupo em questão, no mesmo período.

Fonte: Adaptado de UNCTAD (2009:112)

\footnotetext{
${ }^{56}$ Essa é uma questão que, frequentemente, se coloca no centro das discussões a respeito do real potencial que o Investimento Estrangeiro Direto (IED) teria para fomentar o desenvolvimento da agricultura nos países em desenvolvimento (FAO, 2013a; CEPAL, 2013).

${ }^{57}$ Os dados disponíveis sobre IED na agricultura ainda são muito dispersos. Em geral, os estudos sobre o tema não coseguem encontrar informações consolidadas e padronizadas adequadas para a realização de análises comparativas entre diferentes países ou períodos de tempo. Sendo assim, os dados são frequentemente apresentados no caráter de estimativas, tomando por base períodos maiores de um ano (por exemplo, entre 1989-1991 e 2005-2007), e grupos de países, em representação de uma região ou de determinada situação econômica - por exemplo, países desenvolvidos e em desenvolvimento, como realizado pela UNCTAD (2009). Dessa forma, apesar das deficiências, é possível ter um panorama do comportamento desses fluxos, ajudando a compreender as estratégias das corporações multinacionais do setor, e a lógica da inserção dos diferentes países na dinâmica da cadeia agro-alimentar global.
} 


\section{Figura 2 - Fluxos de IED (inward) na agricultura e agroindústria (1990-2007) - US\$} bilhões

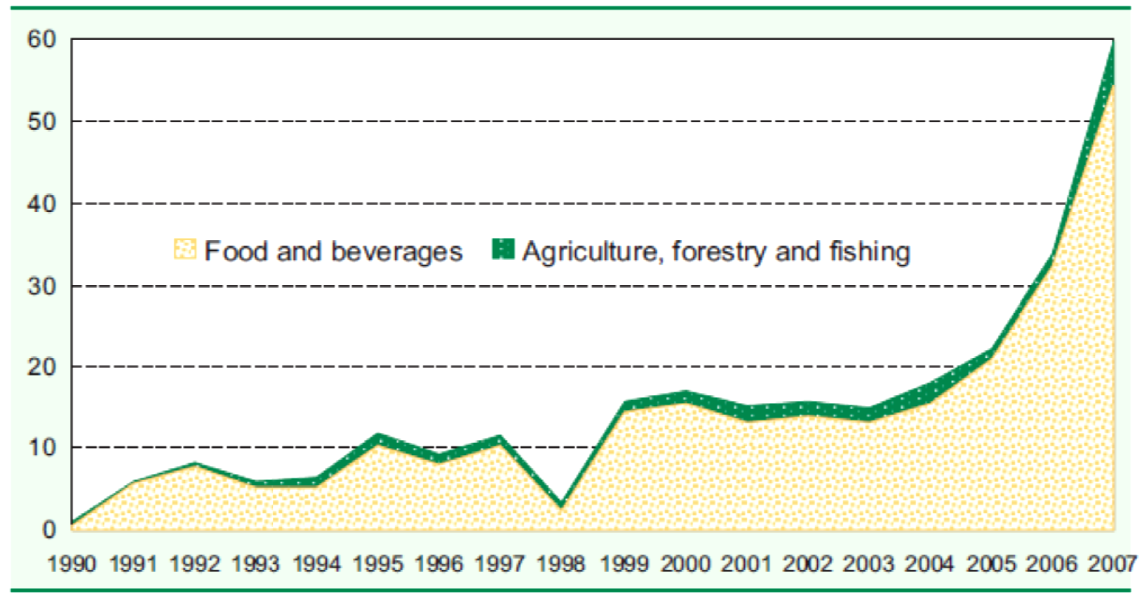

Fonte: UNCTAD (2009:112)

Apesar do aumento significativo no montante global desses fluxos principalmente a partir do ano 2000, conforme se constata na Figura 2 - os investimentos na agricultura e na agroindústria ainda representam uma percentagem mínima dos fluxos totais de investimentos. Na Tabela 3, por exemplo, se observa que entre 1989 e 1991 os investimentos globais em agricultura permaneciam menos de um bilhão de dólares por ano. Em 2005-2007, supera-se a marca dos três bilhões de dólares, porém, esses fluxos continuam a representar menos de $1 \%$ do total do IED globais.

Contudo, os investimentos estrangeiros na agricultura podem assumir uma importância relativa maior nos países que contam com uma base agrícola ampla como é o caso da grande maioria dos países em desenvolvimento - tendo um impacto significativo no desenvolvimento das atividades do setor. Na Tabela 4, pode se apreciar os montantes de IED dirigidos para a agricultura (atividades primárias) em anos recentes, assim como a importância relativa que esses fluxos assumem para os grupos/países apresentados. Verifica-se que, o peso dos fluxos de IED em agricultura é maior nos países em desenvolvimento, ao passo que nos países desenvolvidos é praticamente nulo.

\footnotetext{
58 Nesse esquema, a agricultura se refere às atividades primárias (agricultura, pecuária, silvicultura, caça e pesca) e a agroindústria se refere à elaboração de alimentos e bebidas (incluindo tabaco). O gráfico representa a soma dos países para os quais foram encontrados dados para o período em questão. O número do total de países chega a variar para cada ano, mas consegue cobrir uma média de 45 países, abrangendo em torno de $2 / 3$ do total de fluxos globais (UNCTAD, 2009:112).
} 
Tabela 4 - Fluxos de IED (inward) globais em agricultura* e países selecionados

\begin{tabular}{|l|c|c|c|c|}
\hline \multirow{2}{*}{ Grupo/país } & \multicolumn{2}{c|}{$\begin{array}{c}\text { Fluxos IED } \\
\text { (US\$ milhões) }\end{array}$} & \multicolumn{2}{c|}{$\begin{array}{c}\text { \% do total de IED no } \\
\text { grupo/país }\end{array}$} \\
\cline { 2 - 5 } & $\mathbf{2 0 0 2 - 2 0 0 4}$ & $\mathbf{2 0 0 5 - 2 0 0 7}$ & $\mathbf{2 0 0 2 - 2 0 0 4}$ & $\mathbf{2 0 0 5 - 2 0 0 7}$ \\
\hline Mundial & 2286,9 & 3327,8 & 0,4 & 0,2 \\
\hline Economias desenvolvidas & 156,5 & 38,9 & 0 & 0 \\
\hline Economias em desenvolvimento & 2040,8 & 2980 & $\mathbf{1 , 1}$ & $\mathbf{0 , 8}$ \\
\hline Brasil & 153,3 & 420,9 & $\mathbf{0 , 9}$ & $\mathbf{1 , 6}$ \\
\hline Paraguai & 8,6 & $-11,7$ & $\mathbf{1 2}$ & $\mathbf{- 1 0 , 6}$ \\
\hline
\end{tabular}

* Neste caso, os investimentos em agricultura se referem aos setores de produção primária (agrícola, florestal e pesca) excluindo os bens processados (alimento e bebidas).

Fonte: Adaptado de World Investment Report 2009 (UNCTAD, 2009:237)

Assim, nos países em desenvolvimento - e, em especial, nos países da América Latina - os investimentos em agricultura adquirem um maior peso dentro do total de investimentos recebidos. Porém, dentro desse grupo de países, também se verifica uma ampla variedade quanto à importância relativa do IED agrícola (atividades primárias), como mostra a Figura 3.

Figura 3 - IED acumulada em agricultura na América Latina (2005-2011) - Países selecionados - Em percentagem (\%) do total de IED acumulado por cada país

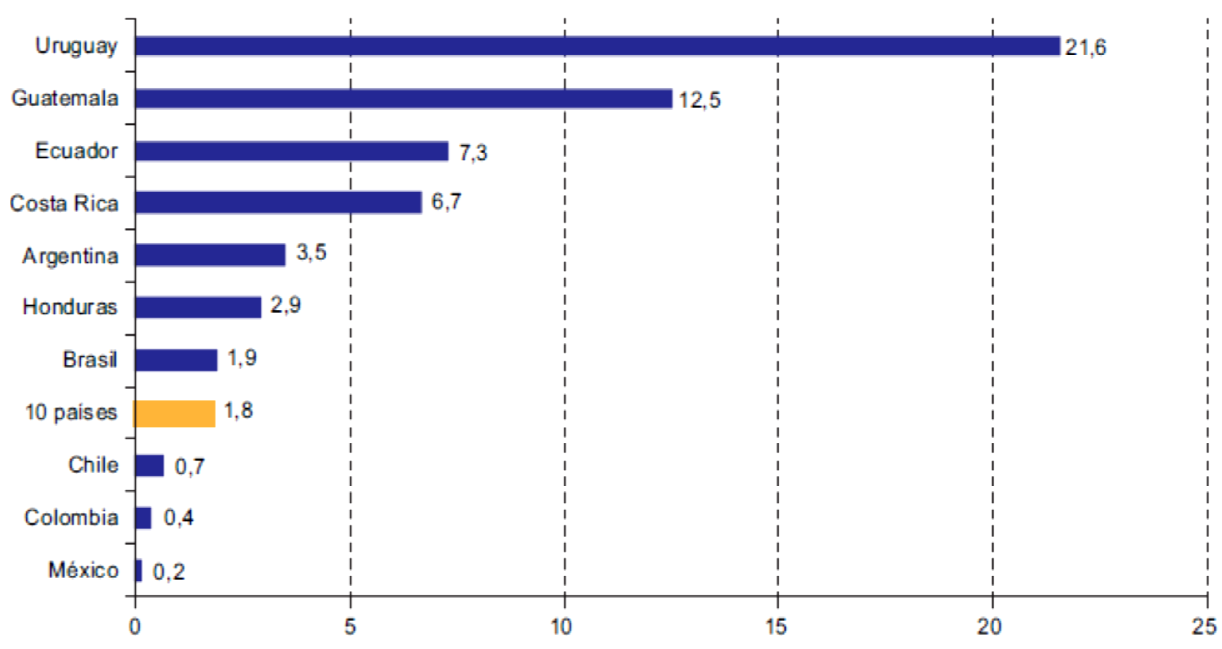

Fonte: CEPAL (2013:108)

A importância do IED na agricultura está fortemente relacionada à estrutura econômica de cada país, isto é, ao espaço que o setor agrícola assume nessa estrutura. Uma análise da situação dos países do Cone Sul - que constituem o foco do presente trabalho - se mostra interessante para elucidar a questão. A 
região do Cone Sul se coloca como um importante destino dos fluxos globais de IED agrícola por conta, principalmente, da ampla disponibilidade de recursos naturais (CEPAL, 2013). Todavia, uma breve comparação dos perfis agrárioeconômico dos países da região (na Tabela 5) evidencia que a atividade agrícola assume diferentes graus de importância em cada economia, sugerindo que os fluxos de IED assumirão comportamentos e impactos específicos em cada país.

Tabela 5 - Perfil agrário-econômico dos países do Cone Sul

\begin{tabular}{|c|c|c|c|c|c|}
\hline & \multirow{2}{*}{$\begin{array}{c}\text { (1) } \\
\text { Participação } \\
\text { da agricultura* } \\
\text { no PIB (2012) }\end{array}$} & \multicolumn{2}{|c|}{$\begin{array}{c}\text { (2) População rural } \\
(\%)\end{array}$} & \multirow{2}{*}{$\begin{array}{l}\text { (3) Participação } \\
\text { de produtos } \\
\text { agrícolas nas } \\
\text { exportações } \\
\text { (2012) }\end{array}$} & \multirow{2}{*}{$\begin{array}{c}\text { (4) Emprego } \\
\text { rural } \\
\text { (\% do total) } \\
2005-2010\end{array}$} \\
\hline & & 2000 & 2011 & & \\
\hline Paraguai*** & 18,1 & 44,7 & 38,1 & 58,5 & 26,5 \\
\hline Brasil & 5,3 & 18,8 & 15,4 & 35,6 & 17 \\
\hline Argentina & 9,0 & 9,9 & 7,5 & 53,3 & 1,2 \\
\hline Uruguai & 7,7 & 8,7 & 7,5 & 73,8 & 11 \\
\hline
\end{tabular}

* Agricultura, pecuária, silvicultura, caça e pesca.

**Nos registros paraguaios de comércio exterior a exportação de energia elétrica é contabilizada no total. Em 2011, sem contabilizar esse bem, a participação dos produtos agrícolas nas exportações totais chega a $87,5 \%$.

Fonte: Elaboração própria com base em dados da CEPALstat (coluna 1); FAO (2013b) (colunas 2 e 4) e da WTOstat (coluna 3).

Verifica-se, de fato, que mesmo quando os maiores volumes de investimentos na região se concentram nos países de maior porte, isto é, no Brasil e na Argentina (ver Tabela 6), no Paraguai e no Uruguai - países com uma forte orientação agroexportadora - os fluxos recebidos adquirem um peso econômico relativamente maior. Para o período 2005-2011, por exemplo, enquanto os estoques de IED agrícola representaram 1,9\% para o Brasil e 3,5\% para a Argentina, no Uruguai correspondeu a $21 \%$ do total dos investimentos estrangeiros acumulados no país (ver Figura 3). O mesmo fenômeno se verifica no caso do Paraguai que, conforme apresentado na Tabela 4, recebeu valores de IED muito inferiores aos do Brasil - e por baixo da média dos países em desenvolvimento - no período em questão. No entanto, a importância relativa desses fluxos foi maior, sendo de $12 \%$ no período entre $2002-2004$, e de $10,6 \%$ no 
período $2005-2007^{59}$, em contraposição aos índices de 0,9\% e 1,6\% no Brasil, respectivamente.

Tabela 6 - Fluxos de IED (inward) para os países do Cone Sul (2000 e 2011)

\begin{tabular}{|l|l|l|l|l|}
\hline \multirow{2}{*}{ Países } & \multicolumn{2}{|c|}{$\begin{array}{c}\text { Agricultura, caça, } \\
\text { silvicultura, pesca } \\
\text { (US\$ milhõe) }\end{array}$} & \multicolumn{2}{c|}{$\begin{array}{c}\text { Alimentos, bebidas, } \\
\text { tabaco (indústria) } \\
\text { (US\$ milhões) }\end{array}$} \\
\cline { 2 - 6 } & $\mathbf{2 0 0 0 - 0 1 *}$ & $\mathbf{2 0 1 0 - 1 1 *}$ & $\mathbf{2 0 0 0 - 0 1 *}$ & $\mathbf{2 0 1 0 - 1 1 *}$ \\
\hline Paraguai & -3 & -1 & 40 & 10 \\
\hline Brasil & 73 & 618 & 453 & 1592 \\
\hline Argentina & 0 & 663 & 6 & 841 \\
\hline Uruguai & -15 & 314 & -6 & 59 \\
\hline
\end{tabular}

* Refere-se aos dados mais recentes em relação ao período em questão

Fonte: Elaboração própria com base em dados da FAO (2013b:54-57)

Ainda a respeito do comportamento dos fluxos globais de IED orientados para a agricultura e atividades relacionadas, cabe destacar as principais tendências da parcela desses fluxos destinada para os países da América Latina - que têm acompanhado o crescimento dos fluxos a nível global. Dessa forma, tem-se uma noção da configuração da cadeia global do agronegócio na região.

O Brasil tem se colocado como destino preferencial desses fluxos na região. Tomando como referência o período de 2003-2011, tem-se que o país se colocou como principal destino de IED em agricultura na região das Américas, superando inclusive os Estados Unidos (FAO, 2013a:24). Já entre 2005-2007, os U\$S 421 milhões recebidos pelo Brasil (ver Tabela 4), representou o terceiro maior fluxo (inward) de IED para o setor agrícola, após a China e a Malásia (FAO, 2013a:30). Outros países latino-americanos que emergem como importantes receptores de IED no âmbito da agricultura (atividades primárias) a partir da segunda metade da década de 2000 são a Argentina e o Uruguai. Já no setor agroindustrial, Brasil México e Argentina se colocam como principais receptores nesse período (CEPAL, 2013) ${ }^{60}$.

\footnotetext{
${ }^{59}$ Apesar de que a tendência nesse período no Paraguai tenha sido de "desinvestimento", tem-se que o impacto nos fluxos totais de IED, também nesse caso, é relativamente maior.

${ }^{60}$ Considerando os fluxos de IED acumulados entre 2005-2010 para uma amostra de dez países da América Latina, a CEPAL (2013) apontou que um total de US\$ 9.255 milhões se destinou para a agricultura (representando $1,8 \%$ do total de IED recebido pelo conjunto nesse período), sendo os principais países receptores: Brasil (38,2\%), Uruguai (22,4\%), e Argentina (14,3\%). Já a IED dirigida para a agroindústria nesses mesmos dez países atingiu o total de 42.933 milhões de
} 
No caso do Cone Sul, os investimentos estrangeiros se dirigem, especialmente, às atividades da cadeia relacionadas à produção dos "cultivos agrícolas básicos" ${ }^{\prime 61}$ - como os cereais (trigo e milho), oleaginosas (soja) e cana de açúcar. Conforme evidenciado anteriormente, as grandes corporações transnacionais do agronegócio têm amplo controle do segmento de fornecimento de insumos para a produção e de processamento e comercialização dos bens agrícolas a nível mundial e, naturalmente, marcam forte presença na região. Destaca-se, por exemplo, as firmas do grupo "ABCD"62 - ADM, Bunge, Cargill e Luis Dreyfus Commodities - do segmento de trading, que assumem um papel central na cadeia de produção agrícola no Cone Sul (principalmente, da soja, conforme será apresentado na próxima seção).

As firmas transnacionais também se consolidam como líderes no segmento de elaboração de alimentos e bebidas. Todavia, nesse âmbito, tem-se observado o surgimento de uma nova geração de empresas agro-alimentares "translatinas", que estão ganhando espaço nos mercados mundiais e regionais. Dentre as 51 maiores empresas agro-alimentares na região da América Latina - listadas no ranking das 500 maiores empresas da região pela revista América Economía (2011, apud CEPAL, 2013:104) - 21 eram firmas translatinas. Nesse grupo, ressalta-se a posição das firmas brasileiras atuantes no mercado da carne, em especial da empresa JBS-Friboi que figura no primeiro lugar entre as empresas do setor agro-alimentar, e na nona posição no ranking das 500 maiores empresas da região (CEPAL, 2013:105) ${ }^{63}$.

Outro segmento, atrelado diretamente à dinâmica de produção dos bens agrícolas básicos, que está experimento um notável crescimento na região e que

dólares no mesmo período (representando $8,3 \%$ do total de IED recebido pelo conjunto), sendo os principais receptores: Brasil (37,9\%), México (35,9\%), e Argentina (15,5\%).

${ }^{61}$ Também chamados de cultivos "flexíveis" (“flex crops"), referem-se aos cultivos que servem de base para elaboração de diferentes produtos agroindustriais, desde alimentos e ração animal, até biocombustíveis (ver nota de rodapé n. 48, no capítulo anterior).

${ }^{62}$ Essa denominação resultou de um artigo publicado no "The Guardian” em 2011 (CEPAL, 2013). O artigo se intitula "The Global Food Crisis: ABCD of food - how the multinationals dominate trade", e está disponível em: http://www.theguardian.com/global-development/povertymatters/2011/jun/02/abcd-food-giants-dominate-trade. Acesso em: 21/05/2014.

${ }^{63}$ De acordo com a CEPAL (2013), a ascensão das empresas translatinas brasileiras de produção e processamento de carne ilustra o grau de disseminação do modelo de negócios integrados verticalmente e internacionalizados, próprios do novo paradigma da produção mundial de alimentos. Seguindo essa estratégia, as quatro grandes empresas brasileiras do setor da carne e produtos derivados - JBS-Friboi, BRF, Marfrig e Minerva - tem conseguido posicionar-se como líderes regionais nesse segmento, conseguindo também expandir sua participação nos mercados mundiais. 
conta com maior participação de atores e firmas locais, é o de elaboração de biocombustíveis. No Cone Sul, Brasil e Argentina se destacam como importantes produtores, principalmente de etanol, no caso do Brasil, e de biodiesel no caso da Argentina. De acordo com a CEPAL (2013), na medida em que esse ramo se encontra em uma fase incipiente de seu desenvolvimento, ainda não se verifica um processo forte de concentração por poucas empresas - como acontece nos demais segmentos - resultando em um maior espaço para a atuação de empresas locais.

Por fim, a ampliação das cadeias agro-alimentares e dos investimentos estrangeiros diretos, tanto a nível regional quanto a nível mundial, tem alimentado tendências de concentração (e desnacionalização) também no âmbito das atividades primárias de produção, apesar de que tal segmento não se coloca (a princípio) como destino preferencial dos fluxos de IED, ou como atividade central das firmas transnacionais do setor - que, conforme evidenciado anteriormente, concentram as suas operações nas atividades relacionadas à agricultura.

De fato, nos últimos anos tem-se assistido a uma rápida dinamização dos mercados de terras, impulsionada pela compra de vastas extensões de terra por capitais (ou estados) estrangeiros, dando lugar ao fenômeno denominado como "landgrabbing” ou "estrangeirização" (FAO, 2012; Borras et. al., 2012). Para além das divergências conceptuais a respeito da definição do fenômeno ${ }^{64}$, os estudos sobre o tema coincidem em apontar para um acirramento do mercado de terras, principalmente, nos países "do sul". Um retrato da geopolítica global da dinâmica de estrangeirização pode ser apreciado na Figura 4.

A respeito dessas tendências na América Latina e no Caribe, Borras et. al. (2012) apontam que na região predomina um caráter "intra-regional" nos processos de apropriação de terras por estrangeiros - isto é, a maior parte dos investimentos estrangeiros na aquisição de terras deriva da própria região. Nesse cenário, destaca-se, por exemplo, a situação do Brasil que, embora se coloque como um importante "ofertador" de terras na região para os investidores estrangeiros, também emerge como importante arrendatário e comprador de terras fora se deu território (Fernandes, 2009; Borras et. al., 2012).

\footnotetext{
${ }^{64}$ A respeito dessa discussão, conferir capítulo três.
} 
Figura 4 - Geopolítica da questão agrária mundial: Mapa dos arrendamentos e/ou compras de terras para a produção de alimentos e agroenergía

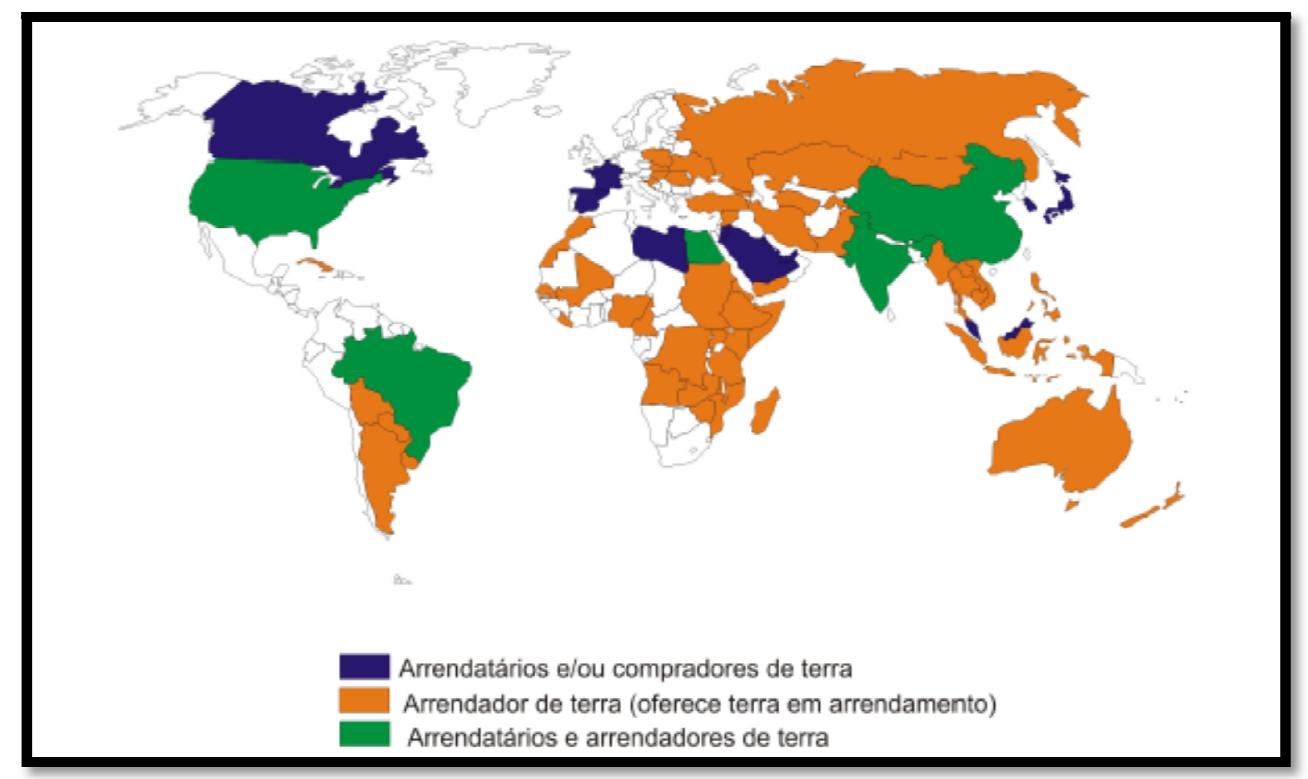

Fonte: Fernandes (2009:3)

Em suma, as evidências apresentadas ao longo da presente seção mostram que a dinâmica de desenvolvimento e integração da produção agrícola e agroindustrial a nível mundial está fortemente assentada na atuação de um pequeno número de grandes firmas transnacionais - em sua maioria, de origem estadunidense e europeia - reafirmando o tradicional padrão de subordinação "norte-sul" nas relações econômicas internacionais. Por outro lado, tem se presenciado, cada vez mais, ao surgimento de novas tendências que desafiam esses padrões tradicionais de divisão do trabalho - especialmente, nos segmentos onde o grau de concentração das atividades permanece baixo, como é no setor de alimentos e o setor de biocombustíveis, no caso da configuração dessas atividades na América Latina.

O comportamento dos fluxos de IED direcionados para a região reflete essas novas tendências, por exemplo, ao verificar-se que maiores parcelas desses fluxos passam a ser destinadas a países como Brasil e Argentina nos últimos anos. Da mesma forma, nesses países se constata um desenvolvimento mais intenso das atividades do agronegócio onde, inclusive, abre-se espaço para a emergência de grandes empresas de origem local, que passam a competir nos mercados regional e mundial nos mesmos padrões das firmas transnacionais. Por fim, a maior participação de capitais e agentes econômicos "do sul” - ou dos países “em 
desenvolvimento" - na estrutura global do agronegócio, também se verifica no fenômeno de landgrabbing (conforme se percebe na Figura 4).

Em última análise, pode-se dizer que essas novas tendências também indicam a existência de graus distintos de desenvolvimento e de integração das estruturas de produção agro-alimentares dos países de uma mesma região ou grupo. No caso, apontam para um aprofundamento das desigualdades econômicas entre os países da América Latina e, particularmente, entre os países do Cone Sul.

\section{2}

\section{A economia da soja no Cone Sul}

A análise dos fluxos de IED na agricultura evidenciou a contínua expansão e consolidação das cadeias agro-alimentares globais na região da América Latina. Todavia, é nos dados sobre o crescimento da produtividade e da superfície cultivada das commodities agrícolas, que se verifica mais claramente a rápida expansão do modelo do agronegócio na região, e a tendência de especialização desses países no fornecimento de matérias-primas agrícolas para a agroindústria global - isto é, de reforço do padrão agroexportador.

No caso do Cone Sul, o cultivo que se coloca como a principal evidência dos desenvolvimentos ocorridos na agricultura nas últimas décadas é a soja. De fato, Argentina, Brasil, Paraguai, Bolívia e Uruguai se apresentam como importantes produtores desse cultivo - sendo que os três primeiros se colocam entre os principais produtores e exportadores de soja a nível mundial. O crescimento massivo da produção de soja na região nas últimas duas décadas pode ser apreciado na Tabela 7.

O cultivo da soja começou a se expandir na região do Cone Sul por volta

dos anos 1960, principalmente, no Brasil, na Argentina e no Paraguai. Porém, é a partir dos anos 1990, que se verifica um crescimento massivo do cultivo nesses países. Entre os principais motivos por trás desse fenômeno se encontram: (1) a dinamização do mercado internacional advinda, principalmente, da intensificação da atividade pecuária na Europa, que implicou uma maior demanda por farelo de soja (utilizado na elaboração de ração animal), e do aumento da demanda da agroindústria alimentar em países com rápido crescimento econômico, como a 
China e a Índia ${ }^{65}$; (2) a incorporação de inovações tecnológicas ao processo de produção, em especial, das sementes geneticamente modificadas - notadamente da marca "Roundup Ready (RR)", da firma Monsanto - e da técnica do plantio direto $^{66}$ (FAO, 2007; Rulli, 2007).

Tabela 7 - Crescimento da superfície (em hectares) e da produção de soja (em toneladas) nos países do Cone Sul

\begin{tabular}{|c|c|c|c|c|c|c|c|c|}
\hline \multirow[b]{2}{*}{ Países } & \multicolumn{2}{|l|}{1990} & \multicolumn{2}{|l|}{2000} & \multicolumn{2}{|l|}{2010} & \multirow{2}{*}{$\begin{array}{c}\text { Variaç } \\
\text { ão } \\
\text { superf. } \\
(1990- \\
2010) \\
\end{array}$} & \multirow{2}{*}{$\begin{array}{c}\text { Variaç } \\
\text { ão } \\
\text { prod. } \\
(1990- \\
2010) \\
\end{array}$} \\
\hline & Superf. & Prod. & Superf. & Prod. & Superf. & Prod. & & \\
\hline Argentina & 4.961 .600 & 10.700 .000 & 8.637 .503 & 20.135 .800 & 18.130 .799 & 52.677 .371 & $\begin{array}{c}265,42 \\
\%\end{array}$ & $\begin{array}{c}392,31 \\
\%\end{array}$ \\
\hline Bolivia & 143.372 & 232.743 & 616.964 & 1.197.251 & 922.115 & 1.917 .150 & $\begin{array}{c}543,16 \\
\%\end{array}$ & $\begin{array}{c}723,72 \\
\%\end{array}$ \\
\hline Brasil & 11.487 .300 & 19.897 .804 & 13.640 .026 & 32.734 .958 & 23.327.296 & 68.756 .343 & $\begin{array}{c}103,07 \\
\%\end{array}$ & $\begin{array}{c}245,55 \\
\%\end{array}$ \\
\hline Paraguai & 899.900 & 1.794 .618 & 1.176 .460 & 2.980 .060 & 2.671 .059 & 7.460 .435 & $\begin{array}{c}196,82 \\
\%\end{array}$ & $\begin{array}{c}315,71 \\
\%\end{array}$ \\
\hline Uruguai & 28.500 & 37.000 & 8.900 & 6.800 & 863.200 & 2.000 .000 & $\begin{array}{c}2928,77 \\
\%\end{array}$ & $\begin{array}{c}5305,41 \\
\%\end{array}$ \\
\hline
\end{tabular}

Fonte: Elaboração própria com base em dados da FAOstat

A disseminação das novas técnicas e insumos tecnológicos para a produção constitui um fato notável da expansão do agronegócio da soja na região. A semente transgênica de soja, por exemplo, foi incorporada primeiramente na Argentina, em 1996, e a partir daí foi sendo introduzida de forma ilegal nos países vizinhos - no Brasil, Paraguai e Bolívia. Posteriormente, os governos desses países acabaram por aprovar oficialmente a utilização da semente transgênica de

\footnotetext{
${ }^{65}$ No Caso da China, o aumento da necessidade de importação de soja também está relacionado ao alto grau de desertificação das áreas cultiváveis no país nas últimas décadas (Rulli, 2007).

${ }^{66} \mathrm{O}$ modelo de produção empresarial da soja consiste na combinação de dois elementos: o pacote tecnológico, composto pela semente transgênica de soja (resistente ao uso de agroquímicos) e por inseticidas e herbicidas; e a técnica do plantio direto, que consiste em não lavrar ou remover a terra. A combinação desses elementos permite a produção em grande escala com a obtenção de maior rentabilidade, na medida em que se dispensa a utilização de mão de obra no cultivo. Essa forma de produção, cada vez mais adotada junto com a expansão do cultivo, explica, em grande parte, a dinâmica de expulsão de pequenos produtores e do aumento do desemprego no campo nesses países. Por outro lado, esse modelo de produção também acarreta consequências nocivas para o meio ambiente, na medida em que a técnica de plantio direto depende amplamente da utilização de agroquímicos, que passam a ser utilizados cada vez em maior volume, contaminando os solos e fontes hídricas (Rulli, 2007).
} 
soja em seus territórios ${ }^{67}$. De acordo com a FAO (2007:3), no final dos anos 1990, a semente de soja "RR" respondia por $75 \%$ da superfície cultivada na Argentina, e $10 \%$ no Brasil. Já por volta de 2007, estimavam-se proporções de $95 \%$ e $35 \%$ respectivamente. Também no Paraguai e no Uruguai, essas proporções seriam altas: para o período de 2004/2005, estimava-se uma proporção de $60 \%$ e $99 \%$ da área cultivada, respectivamente ${ }^{68}$.

Dessa forma, no período 1996-2004, a produção de soja nos países em questão registrou um crescimento recorde, passando de 39 milhões de toneladas em 1996, para aproximadamente 87 milhões em 2004, representando uma expansão 1,7 vezes maior que o crescimento na produção global de soja, superando amplamente o ritmo de crescimento da produção nos Estados Unidos historicamente, o principal produtor e exportador mundial de soja - e indicando que o "boom mundial de soja é essencialmente um fenômeno sul-americano" (FAO, 2007:IX). Em conjunto, os países do Cone Sul passaram a se colocar como principais produtores e exportadores mundiais do cultivo, sendo responsáveis por uma parcela cada vez maior do total produzido e exportado a nível mundial (ver Tabela 8).

A economia da soja, porém, não se restringe aos países do Cone Sul. Trata-se de um esquema de produção que se organiza em nível mundial, por meio de uma longa cadeia de processos e envolvendo diversos atores, indo além do âmbito da produção (cultivo) em si (ver Figura 5). Nesse esquema, os países do Cone Sul se inserem fundamentalmente como principais fornecedores do cultivo, em função da vasta disponibilidade de recursos para sua produção (essencialmente, terra e água). Já as atividades dos demais segmentos - de fornecimento de insumos para a produção, industrialização e comercialização estão amplamente controladas pelas firmas transnacionais do setor.

\footnotetext{
${ }^{67}$ À aprovação da Argentina, seguiu a do Uruguai (em 1998), do Brasil (em 2002-2004), da Bolívia (2003-2005) e do Paraguai (2004) (CEPAL, 2013:132).

${ }^{68}$ Até hoje, a disseminação das sementes transgênicas continua a um ritmo acelerado na região, especialmente, após a aprovação de outros cultivos transgênicos além da soja, como o milho e o algodão. Em 2013, a superfície cultivada com transgênicos - referente às plantações de soja, milho e algodão - chegou a: 40,3 milhões de hectares no Brasil, 24,4 ha. na Argentina, 3,6 ha. no Paraguai, e 1,5 ha. no Uruguai, representando um aumento percentual de $250 \%, 36 \%, 80 \%$ e 275\%, respectivamente, com relação à superfície cultivada com transgênicos em 2006 (James, 2013:3).
} 
Tabela 8 - Evolução da produção mundial de soja e participação relativa dos principais países produtores

\begin{tabular}{|l|l|l|l|l|l|l|}
\hline \multirow{2}{*}{ País } & \multicolumn{3}{|c|}{ Toneladas } & \multicolumn{3}{c|}{ Participação relativa } \\
\cline { 2 - 7 } & \multicolumn{1}{|c|}{$\mathbf{1 9 9 0}$} & $\mathbf{2 0 0 0}$ & $\mathbf{2 0 1 0}$ & $\mathbf{1 9 9 0}$ & $\mathbf{2 0 0 0}$ & $\mathbf{2 0 1 0}$ \\
\hline Mundo & 108.456 .443 & 161.297 .873 & 265.348 .720 & $100,0 \%$ & $100,0 \%$ & $100,0 \%$ \\
\hline Brasil & & & & & & \\
\hline Argentina & 19.897 .804 & 32.734 .958 & 68.756 .343 & $18,3 \%$ & $20,3 \%$ & $25,9 \%$ \\
\hline Paraguai & 10.700 .000 & 20.135 .800 & 52.677 .371 & $9,9 \%$ & $12,5 \%$ & $19,9 \%$ \\
\hline Bolívia & 1.794 .618 & 2.980 .060 & 7.460 .435 & $1,7 \%$ & $1,8 \%$ & $2,8 \%$ \\
\hline Uruguai & 232.743 & 1.197 .251 & 1.917 .150 & $0,2 \%$ & $0,7 \%$ & $0,7 \%$ \\
\hline Total (Cone Sul) & 37.000 & 6.800 & 2.000 .000 & $0,0 \%$ & $0,0 \%$ & $0,8 \%$ \\
\hline & $\mathbf{3 2 . 6 6 2 . 1 6 5}$ & $\mathbf{5 7 . 0 5 4 . 8 6 9}$ & $\mathbf{1 3 2 . 8 1 1 . 2 9 9}$ & $\mathbf{3 0 , 1 \%}$ & $\mathbf{3 5 , 4 \%}$ & $\mathbf{5 0 , 1 \%}$ \\
\hline Estados Unidos & & & & & & \\
\hline China & 54.416 .000 & 75.053 .799 & 90.605 .460 & $50,2 \%$ & $46,5 \%$ & $34,1 \%$ \\
\hline Índia & 11.008 .140 & 15.411 .495 & 15.083 .204 & $10,1 \%$ & $9,6 \%$ & $5,7 \%$ \\
\hline & 2.601 .500 & 5.275 .800 & 12.736 .000 & $2,4 \%$ & $3,3 \%$ & $4,8 \%$ \\
\hline
\end{tabular}

Fonte: Adaptado de FAO (2007:47). Dados dos anos 2000 e 2010 obtidos na FAOstat

Figura 5 - Cadeia global do agronegócio da soja

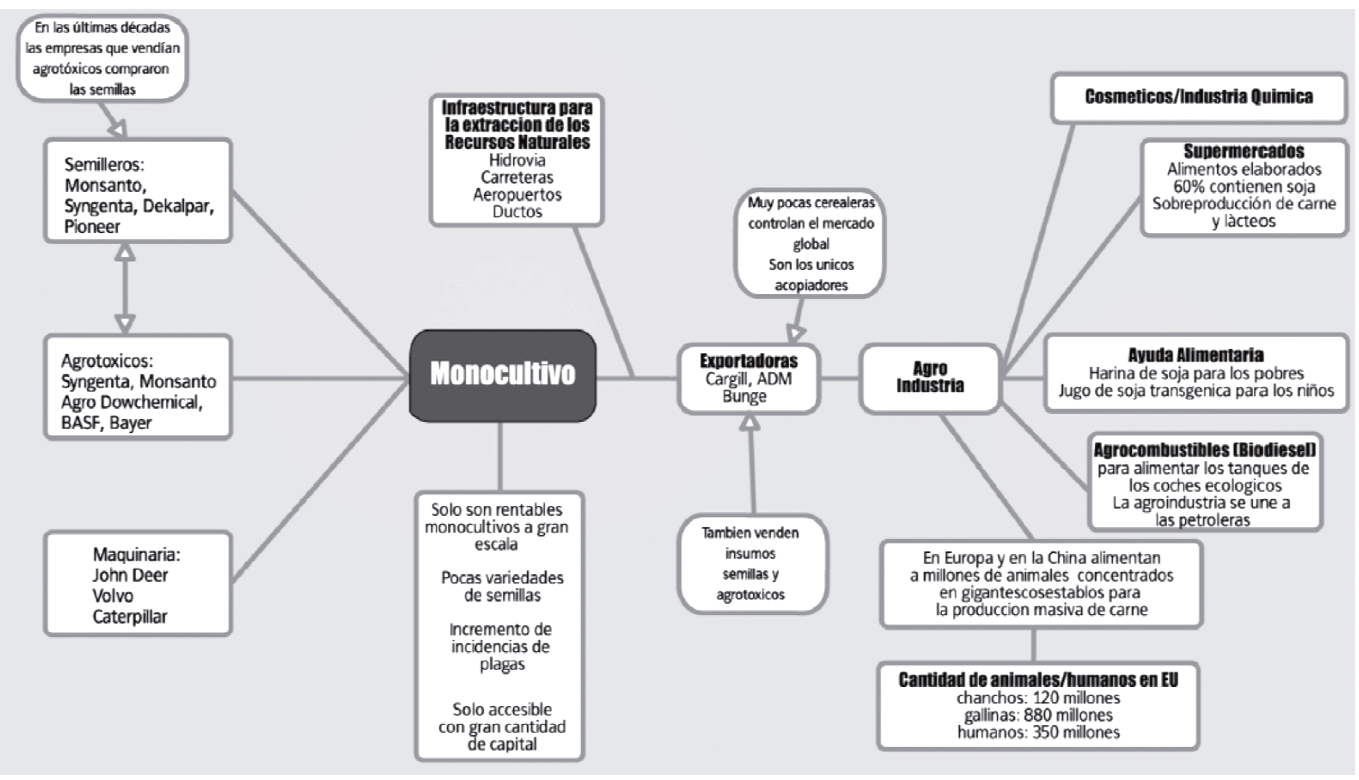

Fonte: Rulli (2007:24)

Conforme visto na seção anterior, as firmas transnacionais controlam amplamente o mercado de insumos para a produção agrícola - com destaque para a firma estadunidense Monsanto, proprietária das principais marcas que compõem o pacote tecnológico utilizado no cultivo de soja na região. O domínio das transnacionais também é notável no segmento de trading, onde ressalta o grupo “ABCD” - ADM, Bunge, Cargill e Louis Dreyfus - que realizam grande parte da 
coleta, processamento e comercialização dos cereais e grãos oleaginosos cultivados na região, atendendo à demanda dos mercadores consumidores e da agroindústria a nível mundial $^{69}$.

As grandes multinacionais de trading têm optado, cada vez mais, por realizar o processamento da soja e de outros cultivos básicos - para a elaboração de farinha e óleo vegetal, produtos que também servem de insumos para a agroindústria - nos mesmos locais onde são produzidas as matérias primas. Dessa forma, nos últimos anos, têm contribuído para o desenvolvimento de indústrias de processamento de grãos oleaginosos e cereais nos países do Cone Sul, sobretudo, na Argentina e no Brasil - e, em menor medida, no Paraguai. Os diferentes graus com que essas indústrias avançam nesses países se relacionam tanto à contínua expansão dos cultivos na região, como à existência de incentivos governamentais e políticas de desenvolvimento voltadas para o crescimento desse segmento. Por exemplo, em anos recentes, o aumento de projetos na região para a elaboração de biodiesel a partir de cultivos oleaginosos (especialmente, de soja) tem se colocado como forte atrativo para os investimentos privados no setor de processamento.

A Argentina tem sido o país que consegue agregar mais valor à soja em seu território, realizando $80 \%$ das exportações na forma de farinha ou óleo, ao passo que o Brasil tem realizado a maior parte de suas exportações de soja em estado bruto, devido, em grande parte, a que a legislação fiscal e comercial existente no país favorece a exportação da soja na forma de grão (Schlesinger e Noronha, 2008) ${ }^{70}$. Por outro lado, a indústria de processamento de grãos e cereais no Brasil tem se mantido em expansão graças à demanda interna (FAO, 2007). No caso do Paraguai, os incentivos governamentais também têm favorecido a exportação de soja em estado bruto ao longo do desenvolvimento do complexo produtivo, porém, nos últimos anos, o setor tem recebido fortes investimentos privados (principalmente, por parte das transnacionais) para o aumento da capacidade interna de processamento de grãos ${ }^{71}$. Já o Uruguai, praticamente, não

\footnotetext{
${ }^{69} \mathrm{Na}$ Figura 5, pode constatar-se a alta versatilidade da soja, que se coloca como um cultivo que pode ser utilizado como matéria prima para a elaboração de: alimentos para o consumo humano; alimentos (ração) para criação de animais; biocombustíveis; entre outros produtos. Sendo assim, entende-se a crescente demanda mundial por trás desse cultivo.

${ }^{70} \mathrm{Em} 2012$, em torno de $67 \%$ do total exportado pelo complexo de produção da soja correspondeu à soja na forma de grão (ABIOVE, 2014).

${ }^{71}$ Entre 2000 e 2012, do total de toneladas produzidas no Paraguai, em média 27\% foi destinado para industrialização, e 70\% diretamente para exportação na forma de grão. Para mais informações a respeito dessa tendência, ver Tabela 15 em anexo.
} 
realiza industrialização, exportando a maior parte de sua produção em estado bruto.

Conforme mencionado anteriormente, as firmas transnacionais assumem um papel central nesses processos, responsabilizando-se por grande parte dos investimentos e, consequentemente, controlando uma ampla parcela da capacidade total de processamento de grãos instalada em cada país. Na Argentina, por exemplo, a Bunge, Cargill e Louis Dreyfus fazem parte do grupo de cinco empresas estrangeiras que controlam 69\% da capacidade diária de esmagamento de soja; ao passo que, no Brasil, as empresas do grupo "ABCD" controlam em torno de $42 \%$ da capacidade diária de processamento (CEPAL, 2013:114). Já no Paraguai, a capacidade diária de processamento dessas mesmas empresas representa perto de $80 \%$ da capacidade total instalada no país (CAPPRO, 2014).

Um resumo sobre a configuração do complexo produtivo da soja nos países mencionados pode ser observado na Tabela 9, onde se ressalta a participação que os diferentes produtos do complexo da soja (grão, farinha e óleo) têm nas exportações totais de cada país. Considerando esses dados, verifica-se que, os produtos derivados do processamento de soja, efetivamente, ocupam uma maior parcela das exportações no caso da Argentina. Por outro lado, tem-se que as exportações de soja na forma de grão ocupam as parcelas mais significativas no caso do Brasil, Paraguai e Uruguai. No caso do Paraguai e Uruguai, as exportações de soja na forma de grão não representam apenas uma característica da configuração do complexo da soja em seus territórios, mas também ilustram o padrão geral de comércio desses países (marcadamente, primário-exportador), pois esse produto também representa uma parcela importante das exportações totais de bens desses dois países.

Por fim, analisando o fluxo global de comércio da soja, tem-se que a cadeia de produção no Cone Sul se orienta em função de uma demanda essencialmente externa à região. Enquanto os países do Cone Sul (principalmente, Brasil, Argentina e Paraguai) se colocam como principais exportadores superando em conjunto aos EUA - os principais importadores de soja do mundo são a China e a União Europeia (ver Figuras 6 e 7). A União Europeia importa uma quantidade relevante de soja em grão, mas a maior parte de suas importações corresponde à farinha de soja, produto utilizado como insumo para a sua indústria pecuária. 
Tabela 9 - Participação do Complexo da Soja nas exportações totais dos países do Cone Sul (2012)

\begin{tabular}{|l|c|c|c|}
\hline \multirow{2}{*}{ País } & \multicolumn{3}{|c|}{ Produtos do Complexo da Soja - (\%) nas exportações totais } \\
\cline { 2 - 4 } & $\begin{array}{c}\text { Farinha de sementes oleaginosas e } \\
\text { outros resíduos de óleo vegetal }\end{array}$ & Óleo de soja & $\begin{array}{c}\text { Soja em } \\
\text { grão }\end{array}$ \\
\hline Paraguai* & 2,7 & 1,9 & 21,7 \\
\hline Brasil & 2,7 & $(\ldots)$ & 7,1 \\
\hline Argentina & 13,2 & 5,3 & 3,9 \\
\hline Uruguai & $(\ldots)$ & $(\ldots)$ & 16 \\
\hline
\end{tabular}

*Nos registros paraguaios de comércio exterior a exportação de energia elétrica é contabilizada no total das exportações de bens. Em 2011, sem contabilizar esse bem, as exportações de soja em grão chegaram a representar 41,6\% do total das exportações do país.

Obs.: Os (...) indicam que se trata de percentagens irrisórias.

Fonte: Elaboração própria com base em dados da CEPALstat

Já as importações chinesas correspondem, majoritariamente, à soja em grão, uma vez que o país importa esse produto a fim de abastecer a sua agroindústria local. De fato, a China se coloca em primeiro lugar entre os países que realizam o esmagamento de soja, sendo responsável por $28,4 \%$ do total esmagado a nível mundial ${ }^{72}$. Um aspecto relevante a esse respeito é que um grande número das fábricas instaladas na China é propriedade das mesmas transnacionais que operam nos principais países exportadores, implicando em que existe muito comércio intra-firma (CEPAL, 2014) ${ }^{73}$. Essa situação é apontada como um dos fatores que conspira contra o surgimento de grandes empresas de trading de nacionalidade diferente da estadunidense, que ainda prevalece como principal origem dessas empresas apesar da ascensão de países como o Brasil, que se coloca atualmente como segundo maior produtor de soja a nível mundial estando prestes a superar os EUA ${ }^{74}$.

\footnotetext{
${ }^{72}$ No ranking mundial de quantidade de soja esmagada (em toneladas métricas) entre 2012/2013, a China é seguida por EUA, que responde por $20,1 \%$ do total mundial; Brasil $(15,1 \%)$ e Argentina $(14,7 \%)$ (USDA, 2014).

${ }^{73}$ Estima-se que Cargill, ADM e Bunge tenham adquirido em torno de $80 \%$ da capacidade de processamento de soja da China no início dos anos 2000 (The Guardian, 2011).

${ }_{74}$ De acordo com o USDA (2014), na safra de 2012/2013, a diferença de produção entre os Estados Unidos e o Brasil foi de apenas 561 toneladas métricas.
} 
Figura 6 - Principais exportadores de soja em grão (2012/2013) - Em mil toneladas métricas e percentagem do total mundial

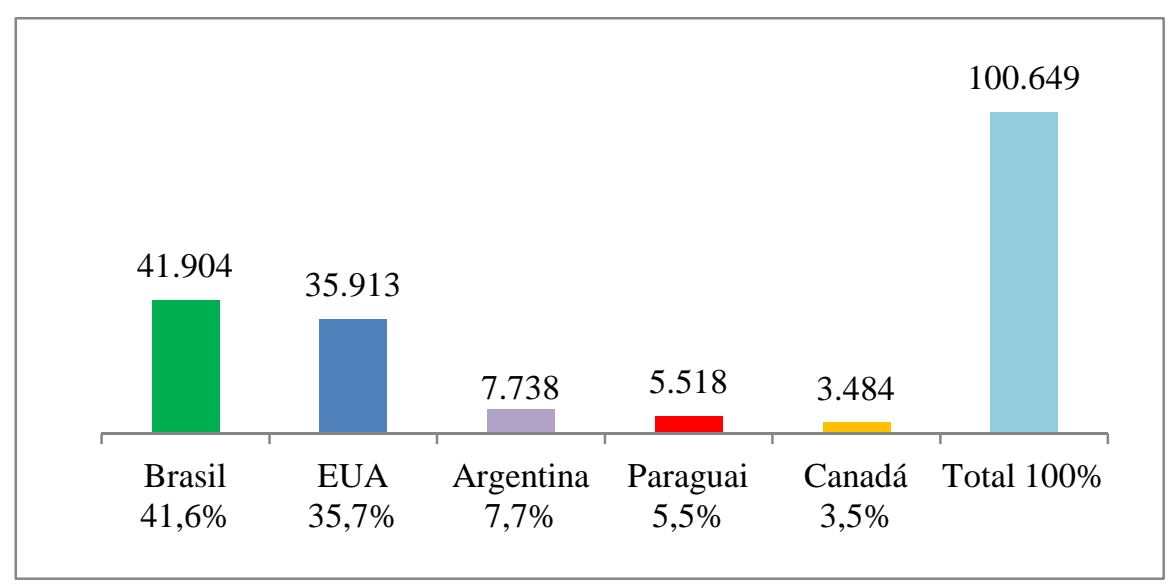

Fonte: Elaboração própria com base em dados do USDA (2014)

Figura 7 - Principais importadores de soja em grão (2012/2013) - Em mil toneladas métricas e percentagem do total mundial

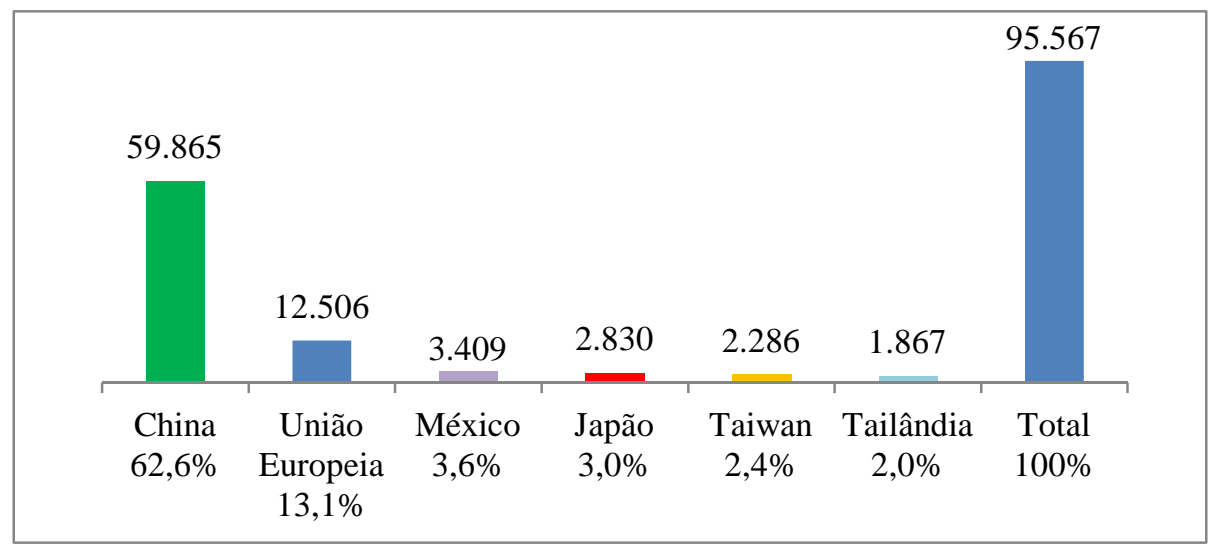

Fonte: Elaboração própria com base em dados do USDA (2014)

Em síntese, a cadeia de produção global da soja estabelece um padrão de relações econômicas no qual os países do Cone Sul se inserem de forma subordinada, na medida em que cultivam cada vez mais soja em seus territórios a fim de atender uma demanda fundamentalmente externa, e o fazem seguindo um modelo de produção fortemente patrocinado pelas firmas transnacionais, que controlam a maior parte do fornecimento de insumos para a produção, e das dinâmicas de coleta, processamento e comercialização mundial dos grãos e seus produtos derivados.

Dessa forma, os países do Cone Sul se sujeitam a uma mesma lógica de integração à cadeia global da soja, que resulta em uma tendência comum de 
reforço do padrão agroexportador nas suas economias. Ao mesmo tempo, os efeitos nocivos provocados pelo modelo de produção empresarial da soja- como o acirramento dos processos de concentração no uso e na propriedade da terra (e a consolidação da grande unidade agrícola), o crescimento dos índices de desmatamento e de perda de biodiversidade, o aumento da contaminação dos solos e recursos hídricos (pelo uso intensivo de agroquímicos), etc. - difundem-se de forma generalizada na região.

Por outro lado, no marco dessa dinâmica de integração dos países do Cone Sul à cadeia global do agronegócio da soja, é possível apontar graus distintos de subordinação, que emergem a partir das estruturas e trajetórias socioeconômicas específicas de cada economia. Isso é perceptível, por exemplo, no grau de desenvolvimento da indústria de processamento da soja em cada país, ou no peso relativo que os produtos do complexo da soja têm no total de suas exportações. A consideração desses aspectos indica que o agronegócio da soja tem um maior dinamismo na Argentina e no Brasil - uma vez que esses países conseguem incorporar maiores segmentos da cadeia em seus territórios - ao passo que denotam uma situação de maior dependência do Paraguai e do Uruguai das atividades primárias de produção de soja e da exportação de bens de baixo valor agregado (isto é, uma maior inclinação para o padrão primário-exportador).

\section{3 \\ Brasil: a potência regional do agronegócio}

Nas seções anteriores constatou-se que, embora estejam sujeitos a uma mesma lógica de integração e subordinação de seus sistemas produtivos agrários, os países do Cone Sul se integram de forma diferenciada à dinâmica global do agronegócio. Alguns países conseguem incorporar em seu território mais segmentos da cadeia global de produção - atraindo maiores fluxos de IED - e gerar espaço para o desenvolvimento de setores e empresas com uma maior composição de capitais nacionais, disputando assim por maior participação nos mercados mundiais. Esse é o caso do Brasil, país que atualmente ganha destaque em diferentes ramos do agronegócio (como na produção de soja, biocombustíveis, e na produção e processamento de carne), façanha que foi possível em função da ampla disponibilidade de recursos naturais para tais empreendimentos e, 
principalmente, graças ao contínuo apoio do governo. No intuito de continuar explorando as tendências de diferenciação intra-regional que acompanham o processo de ampliação das cadeias agro-alimentares na região do Cone Sul, a presente seção se dedica a uma breve descrição da trajetória e das tendências atuais do agronegócio brasileiro.

A posição atual alcançada pelo Brasil na dinâmica global da produção agrícola e agroindustrial diz respeito ao contínuo desenvolvimento de processos que começaram a ganhar impulso a partir da década de 1960. Naquele período, o país começou a experimentar um rápido crescimento de seu setor agroindustrial, impulsionado, em grande medida, pela entrada de investimentos estrangeiros e pela ampliação das atividades das firmas multinacionais do agronegócio no país. Para Sorj (2008:23), inaugurava-se uma nova fase na atuação desses capitais estrangeiros agroindustriais no Brasil, caracterizada por uma "interiorização crescente da produção de insumos para a agroindústria e uma diversificação das indústrias processadoras de alimentos para o mercado interno"75.

Nesse contexto, a implantação de uma indústria de maquinarias e de insumos agrícolas ganhou proeminência, pois, se constituiu em um fator central (e novo) da dinamização do setor agroindustrial e da produção agrícola brasileira. De acordo com Sorj (2008:26), o crescimento da indústria de tratores e maquinaria agrícola foi rápido: para 1975-1976, a produção anual média de tratores atingiu a marca de 53,5 mil unidades, representando um aumento de $575 \%$ com relação à produção anual média em 1960-1962 ${ }^{76}$. Importantes desenvolvimentos também se verificaram no segmento da produção de fertilizantes e de agroquímicos. A produção nacional de fertilizantes entre 1970 e 1976 cresceu 335\% ${ }^{77}$. Já a produção nacional de defensivos agrícolas (inseticidas, fungicidas e herbicidas)

\footnotetext{
75 Naquela época, de fato, o Brasil emergia como plataforma central de expansão do capital estrangeiro na região. No âmbito agrícola, isso derivou em uma mudança na atuação do capital internacional e das firmas multinacionais, que passou a adotar novas características, se diferenciando de sua atuação em momentos anteriores - por exemplo, quando se orientavam fundamentalmente para o controle dos produtos de exportação (até 1930), e quando surgiram as primeiras grandes processadoras de alimentos (entre 1930 e 1960). Todavia, a nova fase não significou o desaparecimento das dinâmicas anteriores. Com feito, a atuação na exportação de matérias primas continuou a ser importante (Sorj, 2008).

${ }^{76}$ Ao mesmo tempo, a área colhida por meio da utilização de tratores apresentou um crescimento de 551\%, passando de 1.947,3 hectares em 1960-1962, para 10.736,5 hectares em 1975-76.

77 A princípio as multinacionais não mostraram interesse na elaboração desses produtos a nível local. A produção nacional só começou a avançar a partir de um maior envolvimento das entidades públicas, como a incursão de uma subsidiaria da Petrobrás no setor, e a criação do "Programa Nacional de Fertilizantes e Calcário Agrícola" pelo governo. O consumo também foi incentivado por meio de políticas de subsídios para compra desses produtos (Sorj, 2008:27).
} 
praticamente dobrou entre 1971 e $1975^{78}$. É importante ressaltar que, embora o apoio estatal tenha sido central para esses desenvolvimentos, o crescimento da agroindústria de insumos agrícolas estava fortemente controlado pelo capital estrangeiro.

Outro aspecto marcante do desenvolvimento da agricultura brasileira desde os anos 1960 foi o crescimento do cultivo da soja no país - que se tornou o carrochefe da incorporação das inovações tecnológicas ao processo de produção agrícola $^{79}$. A soja começou a ser cultivada no sul do Brasil, e até 1976-77, essa região respondeu pela maior parte da produção. O contínuo aumento da demanda internacional motivou o crescimento da produção, levando os produtores a procurar novas áreas para o cultivo. Nesse contexto, aconteceu a expansão da produção de soja para outros estados do Brasil, e também o fenômeno da migração de produtores brasileiros para a região fronteiriça do Paraguai (fenômeno que será analisado em maior profundidade no próximo capítulo).

A respeito da expansão do cultivo da soja para outros estados do Brasil, cabe ressaltar o forte apoio do governo nesse processo. Ressalta-se, por exemplo, o projeto de ocupação do Cerrado brasileiro - bioma que se estende pela região centro-oeste do país. A expansão para o cerrado aconteceu por meio do "Programa de Cooperação Nipo-brasileira para o desenvolvimento Agrícola do Cerrado (PRODECER)", um empreendimento conjunto dos governos do Brasil e do Japão $^{80}$, que começou a ser implementado em 1978 (durando até 2001). Atualmente, tem-se que quase metade da área plantada de soja no Brasil se encontra nessa região (Schlesinger e Noronha, 2006) ${ }^{81}$. Os resultados do PRODECER transcenderam o mero aumento da superfície de cultivo de soja no país, pois, também se colocou como um incentivo para o desenvolvimento de outros âmbitos da produção, como o de pesquisa e desenvolvimento de

\footnotetext{
${ }^{78}$ Passando de 13.898 toneladas em 1971, para 26.561 toneladas em 1975. O setor também recebeu incentivos estatais para seu crescimento, por meio do lançamento (em 1975) do "Programa Nacional De Defensivos Agrícolas", que visava diminuir a dependência das importações (Sorj, 2008:28).

${ }^{79}$ A expansão do cultivo de soja, na época, se colocou como um incentivo para o contínuo crescimento da agroindústria de maquinarias e implementos agrícolas no país, pois, a expansão do cultivo acontecia, cada vez mais, graças à utilização dos novos insumos tecnológicos (Sorj, 2008).

${ }^{80} \mathrm{O}$ interesse do Japão no projeto adveio de sua condição de forte consumidor de soja, e de sua intenção de diminuir a dependência das importações desse produto dos EUA (Schlesinger e Noronha, 2006).

${ }^{81}$ Os principais estados produtores - considerando a safra de 2005/2006 - são: Mato Grosso, Paraná, Rio Grande do Sul, Goiás e Mato Grosso do Sul, que nesse ano responderam por quase 18,1 milhões de hectares produzidos, representando $81,5 \%$ do total (Schlesinger e Noronha, 2006).
} 
tecnologias adaptadas ao clima da nova região de cultivo, contexto no qual se destacou o trabalho da EMBRAPA ${ }^{82}$.

Nos dias atuais, o agronegócio brasileiro vive um intenso dinamismo que se assenta, em grande medida, nos desenvolvimentos apontados anteriormente, em marcha desde 1960. As principais evidências desse dinamismo contemporâneo são: (1) a vigência da indústria de insumos agrícolas (especialmente, de fabricação de máquinas); (2) a diversificação do segmento de industrialização das matérias primas agrícolas com a ascensão, de um lado, da indústria da carne - setor no qual se projeta uma das transnacionais brasileiras mais importantes - e de outro, da indústria dos biocombustíveis (etanol e biodiesel); (3) o contínuo crescimento da produção de cultivos agrícolas básicos, em especial, de soja; (4) e a maior participação do país na competição global por recursos e mercados, que se percebe em seu maior envolvimento em projetos de cooperação internacional na área da agricultura, ou na sua atuação na dinâmica global da "estrangeirização" (onde emerge como grande comprador ou arrendatário de terras em outros países).

O segmento de produção de insumos para a produção agrícola, especialmente, de máquinas e veículos, ainda se coloca como um setor estratégico e determinante da competitividade do agronegócio brasileiro. Conforme relatado anteriormente, o segmento de máquinas agrícolas ganhou impulso a partir da segunda metade do século XX, graças aos incentivos do governo para a expansão do parque industrial nacional. Ao longo da década de 1970 e até meados da década de 1980, a produção nacional de máquinas agrícolas (principalmente, de tratores) cresceu significativamente. Após as décadas de crise e de menor dinamismo econômico (entre os anos 1980 e início dos 1990) - período em que se verifica uma retração desse segmento - a produção volta, gradualmente, a ganhar intensidade nos anos 1990, acelerando-se na última década, motivada pelo crescimento dos cultivos comerciais (Garcia et. al., 2008).

Entre 2000 e 2012, a produção nacional de máquinas agrícolas automotrizes (cultivadoras, tratores de roda e esteiras, colheitadeiras e

${ }^{82}$ A Empresa Brasileira de Pesquisa Agropecuária (EMBRAPA) foi criada em 1973 com o objetivo de promover a pesquisa e desenvolvimento de novos conhecimentos e tecnologias na área da agricultura. No contexto da expansão da fronteira agrícola para o cerrado, a EMBRAPA contribuiu para o desenvolvimento de sementes adaptadas ao clima e o solo da região. Atualmente, a entidade se coloca como referência mundial no âmbito da pesquisa e produção de inovações agropecuárias, mantendo uma ampla rede de parceiros a nível nacional e internacional. No contexto de sua atuação internacional, a empresa também assume um papel central nos programas de cooperação técnica do governo brasileiro (EMBRAPA, 2014). 
retroescavadoras) cresceu significativamente, passando de uma média anual de 43.950 unidades (no triênio 2000-2002), para uma média de 84.697 unidades (no triênio 2010-2012). O aumento na produção também foi acompanhado por um aumento das exportações, que no triênio de 2010-2012 atingiu uma média de US\$ 967,7 milhões, superando amplamente o valor médio do inicio da década, estimado em US\$ 311,1 milhões ${ }^{83}$. Em 2012, a maior parte das exportações brasileiras de máquinas agrícolas se dirigiu para a América do Sul - região que representou 50,3\% do total de unidades exportadas - sendo os principais destinos Argentina (14,5\%), Bolívia $(6,4 \%)$ e Paraguai $(6,0 \%)$ - o que evidencia o importante papel do Brasil como fornecedor desses insumos na região (ANFAVEA, 2013:142). Todavia, é importante apontar que o segmento de produção de máquinas agrícolas é comandado por um pequeno número de grandes empresas estrangeiras que detêm a maior parte da capacidade de produção nacional e dos mercados (Garcia et. al., 2008) $)^{84}$.

As operações de exportação de máquinas e implementos agrícolas produzidos no país têm sido beneficiadas por ações do governo em apoio ao setor exportador, entre as quais se destaca a criação da "Agência de Crédito à Exportação do Brasil - BNDES Exim" em 2010, que consiste em uma linha de financiamento do BNDES para a exportação de produtos e serviços de alto valor agregado - entre os quais, máquinas, motores, equipamentos, caminhões, móveis, etc. ${ }^{85}$. Em 2011, o BNDES ampliou esse programa criando uma nova modalidade: o "BNDES Exim automático", que busca uma maior agilidade operacional no

\footnotetext{
${ }^{83}$ Essas médias de produção nacional e exportação foram estimadas com base em dados da ANFAVEA (2013). Conferir Tabelas 16 e 17 no Anexo.

${ }^{84}$ Os demais produtos do segmento de insumos agrícolas (sementes, fertilizantes, e agroquímicos) também têm uma parte importante de sua produção sendo realizada a nível local, sob o forte domínio das firmas transnacionais do setor. Nesse contexto, o caso da indústria de fertilizantes é representativo. Na década de 1990, o setor passou por um rápido processo de privatização, que implicou na transferência de propriedade de cinco empresas que estavam sob administração estatal desde 1940. Isso resultou em uma reestruturação do setor marcada pelo avanço das empresas transnacionais, com três empresas dominando a produção nacional: Bunge (EUA), Mosaic (EUA) e Yara (Noruega), com destaque para a primeira que, em 2007, tinha uma participação de 31,1\% do mercado brasileiro, sendo a maior empresa de fertilizantes da América do Sul (CEPAL, 2013:135). No final de 2012, a Bunge anunciou a venda da sua área de fertilizantes (misturadoras, armazéns e marcas) para a Yara, fortalecendo a tendência de concentração e desnacionalização do setor. A respeito dessa operação, ver notícia publicada pela Bunge, disponível em: http://www.bunge.com.br/sustentabilidade/2013/port/ra/18.htm\#.U4IQaXJ5Ook. Acesso em $25 \mathrm{de}$ maior de 2014.

${ }^{85}$ De acordo com o BNDES, o objetivo da medida é "robustecer as vendas externas brasileiras, ampliando as oportunidades de acesso ao mercado internacional para produtos e serviços de alto valor agregado, fabricados e originados no país" (BNDES, 2010).
} 
financiamento das exportações brasileiras, através do estabelecimento de parcerias com bancos localizados no exterior, especificamente, na região da América Latina (que seria a área de maior demanda por bens de capital do Brasil) e na África ${ }^{86}$. Até inícios de 2014, o BNDES já havia estabelecido parcerias com 32 bancos na América Latina, e com quatro bancos na África, avançando um total de 77 operações na sua fase piloto (2010-2013), no valor de US\$ 115.889 - dos quais, $42,7 \%$ teria sido aprovado para o setor de máquinas agrícolas ${ }^{87}$.

Outro segmento do agronegócio em que o Brasil adquire transcendência atual é no da industrialização dos bens agropecuários básicos, especificamente, no ramo de processamento de carnes (bovina, suína e aves) e produtos derivados, e no ramo dos biocombustíveis (produzidos, especialmente, a partir de cana de açúcar e de soja), sendo atividades que contam com decisivo apoio do governo. Nesses setores tem se presenciado à ascensão de importantes empresas, que têm conseguido competir no mesmo patamar das grandes empresas transnacionais.

A indústria brasileira da carne passou por um intenso processo de concentração e internacionalização na última década. Atualmente, quatro grupos dominam o mercado: a JBS-Friboi, Marfrig, BRF e Minerva. A empresa JBS, por sua parte, se transformou na maior processadora e exportadora de proteína animal do mundo, posição alcançada por meio de uma série de aquisições e novos investimentos no exterior, que se aceleraram desde 2004. As operações externas de compra realizadas pela JBS entre 2005 e 2011 chegaram à soma de US\$ 3.200 milhões, referentes à compra de empresas e unidades de processamento na Argentina, nos Estados Unidos e na Austrália (CEPAL, 2013:128).

$\mathrm{O}$ apoio financeiro do BNDES foi um fator essencial para o processo de internacionalização da JBS, em especial, para a compra da empresa argentina "Swift Armour" em 2005 (maior produtora e exportadora de carne bovina desse país) pelo valor de US\$ 200 milhões, dos quais US\$ 80 milhões foram obtidos junto ao banco; e para a aquisição da firma estadunidense "Swift Food Company", realizada em 2007, pelo valor de US\$ 1.400 milhões, dos quais US\$ 1000 milhões

\footnotetext{
${ }^{86} \mathrm{O}$ novo produto foi criado a partir da demanda dos exportadores, buscando dar maior agilidade ao financiamento das exportações brasileiras de máquinas, equipamentos e demais itens de maior valor agregado, que são produtos que enfrentam um contínuo acirramento da concorrência internacional. O primeiro acordo do BNDES sob essa modalidade foi realizado com o Banco do Brasil, habilitando as suas agências no Brasil e no exterior a atender aos importadores de bens de capital brasileiros interessados nessa linha de crédito (BNDES, 2011).

${ }_{87}$ Informação disponibilizada pela "Associação Brasileira da Indústria de Máquinas e Equipamentos" (ABIMAQ, 2014).
} 
foram obtidos junto ao banco, fazendo com que o BNDES passasse a participar da estrutura acionária da empresa (CEPAL, 2013:129).

No âmbito dos biocombustíveis, o Brasil também tem alcançado um lugar de destaque a nível mundial, colocando-se como segundo maior produtor de etanol do mundo (produzido a base de cana de açúcar) atrás dos EUA, e também como um importante produtor de biodiesel (a base de cultivos oleaginosos, como soja e palma). A conquista dessa posição no mercado mundial foi possível em função das vantagens existentes para a produção dos cultivos base (como a ampla disponibilidade de recursos naturais, sobretudo, de terra) e, em especial, do conhecimento tecnológico acumulado e do desenvolvimento institucional adquirido ao longo das últimas décadas ${ }^{88}$.

Os incentivos governamentais para a produção de biocombustíveis têm sido centrais para o contínuo crescimento do setor. No caso do etanol, além de estabelecer a política obrigatória de adição (de etanol à gasolina) - desde 1993, oscilando entre uma taxa de $20 \%$ a $25 \%$ - o governo tem oferecido outros benefícios, como incentivos fiscais, e a disposição de créditos por meio de diferentes entidades, sendo o BNDES um dos principais ${ }^{89}$. No caso do biodiesel, também ficou estipulado, desde 2005, a adição obrigatória (de biodiesel ao diesel). Além disso, ressalta-se o "Programa Nacional de Produção e Uso de Biodiesel", lançado pelo governo em 2004, que dispõe de uma série de benefícios fiscais para a produção, visando também promover a integração da agricultura familiar à dinâmica ${ }^{90}$. Finalmente, o apoio do governo também tem sido central

\footnotetext{
${ }^{88}$ Central nessa trajetória foi o lançamento do "Programa Proálcool" pelo governo, em 1975, como resposta à crise do petróleo de 1973. O projeto tinha como objetivo diminuir a dependência das importações de petróleo. Por meio do programa, o governo colocou a disposição diversos tipos de subsídios à produção de etanol (de crédito, fiscais e preço, além de políticas de incentivo ao consumo). Dessa forma, entre 1975 e 1979, a produção de etanol aumentou rapidamente, passando de 600 milhões de litros para 3.400 milhões (Fritz, 2008).

${ }^{89}$ De acordo com Fritz (2008), entre 2003 e 2006, o BNDES desembolsou mais de US\$ 2.300 milhões para a indústria do etanol. Nesse quadro, cita-se também o papel da Petrobrás, que além de investir na produção, tem um papel essencial no desenvolvimento da infraestrutura de transporte e comercialização do etanol.

${ }^{90}$ O programa aplica um sistema de benefícios tributários por níveis, que variam de acordo com o produtor, a região e a matéria prima utilizada. Nesse esquema, a compra de matérias primas da agricultura familiar resulta em maiores desonerações, que chegam até 100\% quando esses bens são adquiridos nas regiões Norte e Nordeste. Embora o programa busque uma maior integração socioeconômica na cadeia de produção, Fritz (2008) aponta que ele acaba funcionando como mais um incentivo para a expansão das grandes indústrias processadoras de óleo vegetal. Schlesinger e Noronha (2008), também argumentam que o "Programa Nacional do Biodiesel" engatinha, na prática, em direção à monocultura de soja e ao aprofundamento do domínio das empresas transnacionais, na medida em que, o segmento de processamento e comercialização de óleos
} 
nas atividades de pesquisa sobre o tema, contexto no qual se destaca o trabalho da EMBRAPA, que mantém um centro de pesquisa sobre agro-energía (Fritz, 2008).

Por outro lado, o crescimento do setor de biocombustíveis no Brasil tem sido impulsionado por capitais privados estrangeiros, que investem na instalação das novas plantas processadoras. De acordo com a CEPAL (2013), em 2008, 23,27\% da capacidade de processamento de cana de açúcar no Brasil (para a elaboração de açúcar e etanol) estava total ou parcialmente controlada por empresas estrangeiras, tendência que deve se aprofundar nos próximos anos em função da crescente demanda mundial, dos fortes incentivos do governo brasileiro para o desenvolvimento do setor, e do crescente interesse de investidores estrangeiros $^{91}$.

Naturalmente, a emergência de novas demandas e mercados para os cultivos agrícolas estimula o constante crescimento da produção no país, seja pela intensificação da utilização de novos insumos tecnológicos, ou pela expansão da área de cultivo. No caso da soja, por exemplo, a motivação para o contínuo crescimento da produção deriva do fato que esse cultivo serve tanto para a elaboração de ração animal, utilizada na atividade pecuária (alimentando assim a indústria da carne), como para a elaboração de óleos vegetais, para o consumo humano, ou para o consumo industrial (na elaboração de biodiesel). As expectativas do aumento da produção das matérias primas agrícolas no país, certamente, resultam em um acirramento da demanda por recursos naturais, e também em um agravamento dos dilemas socioambientais que circunscrevem a distribuição e o uso desses recursos. Para os grandes produtores, isso implica uma elevação dos custos da expansão, e a consequente necessidade de procurar novas áreas e recursos (mais baratos) para os novos empreendimentos.

Assim, na medida em que o Brasil desponta como líder mundial e regional em diversos segmentos agroindustriais, o país também se insere, de forma significativa, na atual corrida internacional por recursos (sobretudo, por terra), no intuito de assegurar a provisão das matérias primas agrícolas, aos menores custos possíveis, para o contínuo crescimento de sua agroindústria. Nesse contexto, o

vegetais no país e na região já se encontra fortemente oligopolizado por essas firmas, e que o aumento da produção de biodiesel se assentará, necessariamente, em um amplo crescimento da produção dos cultivos básicos (especialmente, da soja).

91 Nesse quadro, estima-se, também, o aumento da participação de empresas petroleiras, em substituição dos grupos agrícolas, na medida em que essas companhias cada vez mais reconhecem a importância estratégica dos biocombustíveis para seus negócios futuros (CEPAL, 2013). 
Brasil tem assumido um papel duplo, colocando-se, ao mesmo tempo, como plataforma para a expansão de projetos estrangeiros agroindustriais, e como agente promotor da expansão desses projetos em outros países ${ }^{92}$.

A política externa brasileira parece refletir cada vez mais essa prerrogativa. Muitas das iniciativas recentes do Brasil, relacionadas à cooperação para o desenvolvimento ou à integração regional, estão sendo interpretadas como estratégias para assegurar mercados e fontes externas de recursos e matérias primas, que servirão para atender a crescente demanda dos projetos agroindustriais realizados no país (Semino, 2007).

De fato, nos últimos anos, o Brasil tem avançado diversos convênios de cooperação técnica em agricultura, em especial, com os países da América do Sul. Destacam-se, por exemplo, projetos dirigidos pela EMBRAPA em países como Colômbia, Equador, Peru e Paraguai ${ }^{93}$, orientados ao desenvolvimento das cadeias de produção de biocombustíveis - seja pela promoção da pesquisa sobre cultivos alternativos que possam servir como base para a produção de biodiesel; pela capacitação de técnicos sobre o tema; ou pelo desenvolvimento de processos produtivos para a elaboração local de biocombustíveis ${ }^{94}$. A cooperação brasileira em agricultura também tem sido forte na África, onde se localizam os projetos de maior envergadura. Nesse contexto, ressalta-se o projeto "PROSAVANA" avançado em conjunto entre Brasil, Japão e Moçambique - para a modernização da agricultura moçambicana, que se realizará por meio da replicação de técnicas

\footnotetext{
${ }^{92}$ Conforme visto anteriormente, esse caráter duplo se reflete na atuação do Brasil na dinâmica global do landgrabbing ou "estrangeirização". Nesse quadro, o Brasil se coloca como importante centro de arrendamento e venda de terras para investidores estrangeiros, mas também como importante arrendatário e comprador de terras no exterior, principalmente na região da América Latina (Fernandes, 2009; Borras et. al., 2012).

${ }^{93}$ Alguns exemplos de projetos realizados no Paraguai em anos recentes são: "Desenvolvimentos de técnicas para a produção de matérias primas de biocombustíveis no Paraguai", entre 2006 e 2013 (BRA/04/044-S067); "Capacitação técnica de pesquisadores nas principais cadeias produtivas do agronegócio do Paraguai", entre 2007 e 2010, (BRA/04/044-S070); e "Mapeamento de Material Genético e da Produção de Matérias Primas de Biocombustíveis no Paraguai”, entre 2008 e 2009 (BRA/04/043-A128). Informações disponíveis na página web da Agência Brasileira de Cooperação (ABC): http://www.abc.gov.br/projetos/. Acesso em março de 2014.

94 A descrição breve de alguns desses projetos são listados na página web da Embrapa: https://www.embrapa.br/projetos-pontuais. Acesso em 26 de maio de 2014.

${ }^{95} \mathrm{O}$ "Projeto de Melhoria da Capacidade de Pesquisa e de Transferência de Tecnologia para o Desenvolvimento da Agricultura no Corredor de Nacala" (PROSAVANA), tem por objetivo contribuir para o aumento da produção agrícola nessa região do país. A esse respeito, ver: https://www.embrapa.br/prosavana. Acesso em 26 de maio de 2014.
} 
desenvolvidas pela EMBRAPA ao longo da experiência brasileira no desenvolvimento do Cerrado (PRODECER), pois, se trata de biomas parecidos ${ }^{96}$.

Em suma, o Brasil está se colocando como uma importante plataforma para a expansão de projetos agrícolas e agroindustriais globais na região, atraindo a maior parte dos investimentos estrangeiros e gerando incentivos para a incorporação local de maiores segmentos dessas cadeias. Ao mesmo tempo, o Brasil emerge como importante ator na dinâmica global do agronegócio, a partir da ascensão internacional de empresas de origem local, e de sua maior participação em projetos internacionais de desenvolvimento e de integração regional, relacionados à agricultura. Trata-se de uma trajetória que começou a ganhar impulso desde a segunda metade do século XX.

Percebe-se assim, que a dinâmica e a estrutura do agronegócio brasileiro destoam amplamente da situação dos demais países da região - embora todos se encontrem sob uma condição similar de subordinação aos oligopólios das transnacionais do setor, e de reforço do padrão agroexportador em suas economias. O contraste é mais nítido quando são considerados os países menores que, em função de seu desenvolvimento relativamente menor, integram-se às cadeias agro-alimentares, complementando a subestrutura regional liderada pelo Brasil.

\subsection{1 O Paraguai na órbita regional do agronegócio liderada pelo Brasil}

Conforme visto ao longo deste capítulo, na região do Cone Sul, as cadeias de produção agrícola e agroindustrial se organizam de tal forma que, países menores como Paraguai e Uruguai (e também Bolívia), experimentam um maior grau de especialização na produção e exportação de matérias primas agrícolas, ao passo que os países maiores - Brasil e Argentina - conseguem uma diversificação relativamente maior dentro desse padrão comum que os sujeita aos mercados

\footnotetext{
${ }^{96}$ Considerando as consequências socioambientais negativas que o programa PRODECER provocou no Brasil - como a desmatamento massivo, o deslocamento de pequenos produtores rurais e de comunidades indígenas, e a crescente contaminação dos solos e recursos hídricos pelo uso intensivo de agroquímicos - surgem preocupações e suspeitas a respeito dos benefícios efetivos que o PROSAVANA poderá gerar no sentido de promover um desenvolvimento sustentável da agricultura em Moçambique, conforme se propõe (Clements e Fernandes, 2013).
} 
agro-alimentares globais e à atuação das empresas transnacionais. Essa diferenciação se coloca na base do fenômeno da expansão de capitais e empresários brasileiros no Paraguai, e será analisada em maior detalhe no próximo capítulo.

Por enquanto, cabe analisar os desdobramentos desse processo de desenvolvimento desigual do agronegócio na região, em termos da relação comercial que se estabelece entre o Brasil e o Paraguai. Essa análise permite vislumbrar o grau de complementaridade entre as estruturas produtivas agropecuárias desses dois países (ou, em outras palavras, o grau da "divisão do trabalho" entre ambos, no âmbito da expansão do agronegócio na região).

Tabela 10 - Padrão de intercâmbio comercial Brasil-Paraguai - Anos selecionados

\begin{tabular}{|c|c|c|c|}
\hline EXPORTAÇÃO & 2008 & 2010 & 2012 \\
\hline Total exportado pelo Paraguai - US\$ mil & 6.407 .112 & 6.516 .556 & 7.283 .874 \\
\hline Total exportado pelo Paraguai ao Brasil - US\$ mil & 2.184 .915 & 2.194 .778 & 2.850 .332 \\
\hline (\%) das exportações paraguaias para o Brasil & $34,10 \%$ & $33,68 \%$ & $39,13 \%$ \\
\hline Principais produtos - (\%) do valor total exportado ao Brasil & \multicolumn{3}{|c|}{$\%$} \\
\hline 1. Combustíveis e óleos minerais* & $72,82 \%$ & $71,19 \%$ & $62,24 \%$ \\
\hline 2. Cereais & $12,65 \%$ & $11,03 \%$ & $16,93 \%$ \\
\hline 3. Sementes e frutos oleaginosos & $2,15 \%$ & $2,23 \%$ & $4,71 \%$ \\
\hline 4. Carnes e miudezas comestíveis & $0,86 \%$ & $1,59 \%$ & $3,67 \%$ \\
\hline 5. Plásticos e suas obras & $0,91 \%$ & $2,46 \%$ & $1,82 \%$ \\
\hline 6. Gorduras e óleos animais ou vegetais & $1,06 \%$ & $1,19 \%$ & $1,39 \%$ \\
\hline IMPORTAÇÃO & 2008 & 2010 & 2012 \\
\hline Total importado pelo Paraguai - US\$ mil & 8.532 .087 & 9.393.216 & 10.756 .391 \\
\hline Total importado do Brasil pelo Paraguai - US\$ mil & 2.317 .599 & 2.280 .658 & 2.550 .594 \\
\hline$(\%)$ das importações paraguaias oriundas do Brasil & $27,16 \%$ & $24,28 \%$ & $23,71 \%$ \\
\hline Principais produtos - (\%) do valor total importado do Brasil & \multicolumn{3}{|c|}{$\%$} \\
\hline 1. Caldeiras, máquinas, aparelhos e instrumentos mecânicos & $17,33 \%$ & $16,21 \%$ & $13,42 \%$ \\
\hline 2. Adubos ou fertilizantes & $15,44 \%$ & $11,14 \%$ & $11,33 \%$ \\
\hline 3. Combustíveis e óleos minerais & $7,59 \%$ & $6,55 \%$ & $8,95 \%$ \\
\hline 4. Veículos automóveis, tratores, etc. e suas partes & $9,94 \%$ & $9,06 \%$ & $6,65 \%$ \\
\hline 5. Máquinas, aparelhos, materiais elétricos e suas partes & $4,37 \%$ & $6,47 \%$ & $4,91 \%$ \\
\hline 6. Plásticos e suas obras & $3,54 \%$ & $4,26 \%$ & $4,61 \%$ \\
\hline
\end{tabular}

Obs.: Os principais produtos se referem às seções da Nomenclatura Comum do MERCOSUL (NCM).

* Os registros de comércio exterior do Paraguai incluem nessa seção a exportação de energia elétrica, produto que não é contabilizado nos registros feitos pelo Brasil. Sem contar com o valor das exportações de energia elétrica para o Brasil, a participação relativa dos demais produtos ganha destaque. Considerando os registros do MDIC do Brasil, tem-se que, em 2012, as exportações paraguaias para o Brasil (ou, as importações brasileiras desde o Paraguai) representaram, no caso dos cereais $44,52 \%$ do valor total exportado; no caso das sementes e frutos oleaginosos (12,04\%); das carnes e miudezas $(10,47 \%)$; dos plásticos e suas obras $(5,12 \%)$; e das gorduras e óleos animais ou vegetais $(4,08 \%)$.

Fonte: Elaboração própria com base em dados do Banco Central do Paraguai (BCP, 2014a) e do Ministério do Desenvolvimento, Indústria e Comércio (MDIC) do Brasil (2014) 
Na Tabela $\mathbf{1 0}^{97}$, é possível apreciar o padrão de intercâmbio comercial entre o Brasil e o Paraguai em anos recentes. Primeiramente, verifica-se que o Brasil representa um importante "sócio comercial" para o Paraguai, respondendo por mais de $30 \%$ e $20 \%$ de suas exportações e importações, respectivamente ${ }^{98}$. Entre os principais produtos enviados ao Brasil pelo Paraguai nesses anos, figuram quatro itens relacionados diretamente à atividade do agronegócio: cereais e sementes oleaginosas; carnes e óleos vegetais e animais. Trata-se, basicamente, de produtos primários de pouco valor agregado. Já, dentre os principais produtos importados do Brasil pelo Paraguai, figuram dois itens relacionados diretamente à atividade do agronegócio: as maquinarias, veículos e implementos (entre os quais se inserem os insumos para a produção agrícola, como tratores) e os adubos e fertilizantes. Dessa vez, trata-se, essencialmente, de bens de maior valor agregado.

Com base nesses dados verifica-se que, o Paraguai exporta para o Brasil, basicamente, produtos de menor valor agregado, ao passo que importa, maiormente, bens de alto valor agregado. Nesse sentido, pode-se afirmar que emerge um padrão de "intercâmbio desigual" entre esses países, fenômeno que está diretamente relacionado ao processo de desenvolvimento desigual da agricultura capitalista nesses países - isto é, à configuração diferenciada do modelo do agronegócio em cada país.

Assim, embora ambos os países se insiram no esquema global do agronegócio como importantes fornecedores de insumos agrícolas, colocando-se entre os principais produtores e exportadores mundiais de soja - e, sujeitando-se às determinações dos oligopólios internacionais do agronegócio - a economia paraguaia experimenta um maior grau de especialização na produção de bens primários para exportação, tendo uma importante parcela de sua dinâmica agrárioeconômica atrelada ao ritmo de desenvolvimento do agronegócio no Brasil.

\footnotetext{
${ }^{97}$ É importante mencionar que, na elaboração da Tabela 10, foram priorizados os dados de comércio contabilizados pelo Banco Central do Paraguai (BCP), que inclui o valor das exportações de energia elétrica no valor total das exportações paraguaias - o que deriva, por vezes, em um saldo comercial positivo para o Paraguai (como se verifica no ano de 2012). Já ao considerar os dados registrados pelo MDIC (2014), que não contabiliza esse bem nos intercâmbios entre o Paraguai e o Brasil, o saldo comercial entre esses dois países resulta sempre favorável ao Brasil.

${ }^{98}$ É preciso apontar que o contrário não acontece, isto é, o peso do Paraguai como destino ou origem no comércio total de bens do Brasil é irrisório. De acordo com registros do Ministério de Desenvolvimento, Indústria e Comércio do Brasil (MDIC), as exportações brasileiras para o Paraguai representaram 1,26\% do total exportado pelo Brasil em 2008 e 2010; e 1,08\% em 2012. Já as importações brasileiras oriundas do Paraguai representaram apenas $0,38 \%$ do total importado pelo Brasil em 2008; 0,34\% em 2010, e 0,44\% em 2012.
} 
Tais considerações precisam ser levadas em conta na discussão a respeito do papel dos capitais e agentes econômicos brasileiros no desenvolvimento do agronegócio no Paraguai.

\section{4}

\section{Considerações finais do capítulo}

Conforme apresentado ao longo do capítulo, no marco da dinâmica de integração imperialista do agronegócio na América Latina (particularmente, nos países do Cone Sul), é possível identificar padrões de diferenciação intra-regional que permitem ensaiar a hipótese do estabelecimento de uma dinâmica de "divisão regional do trabalho". Isto é, ao mesmo tempo em os países do Cone Sul estão igualmente sujeitos a um processo de integração às cadeias agroindustriais globais comandado pelos oligopólios das firmas transnacionais do setor - passando pelos mesmos processos de internacionalização e desnacionalização de seus sistemas produtivos - que resulta na sua participação como importantes fornecedores globais de commodities agrícolas, tem-se evidências de uma integração diferenciada desses países a essa estrutura, implicando o estabelecimento de dinâmicas secundárias de subordinação econômica entre esses países e seus agentes econômicos.

O caso da penetração de capitais, empresários e produtores brasileiros no meio rural paraguaio é representativo desse processo de desenvolvimento desigual. Com efeito, esse fenômeno resultou, em grande parte, do intenso desenvolvimento do setor agrícola e agroindustrial brasileiro, que alcançou um maior dinamismo na medida em que o país conseguiu incorporar maiores segmentos da cadeia de produção agroindustrial em seu território, atraindo maiores fluxos de investimentos, e resultando em uma crescente necessidade de novos mercados e fontes de matérias-primas. Nesse contexto, ganha impulso a expansão para o Paraguai, país que, por sua vez, passa a se colocar cada vez mais como peça complementar do dinamismo regional do agronegócio concentrado no Brasil.

Contudo, é importante ressaltar que, essa divisão de funções dentro da região se subordina ao esquema mais amplo de divisão internacional do trabalho no âmbito do agronegócio. Isso se constata, por exemplo, no fato de que a 
expansão brasileira no Paraguai ganha maior transcendência no ramo da produção primária, que constituiu um segmento menos procurado pelas grandes transnacionais do setor. Da mesma forma, as empresas ou cooperativas brasileiras que emergem no setor de grãos e cereais - acompanhando o forte crescimento da produção desses cultivos no país - passam a ter seu crescimento constrangido pelas operações das grandes transnacionais de trading, que controlam uma ampla parcela do processamento e comercialização das commodities agrícolas a nível mundial.

Em suma, a consideração das tendências de diferenciação "intra-regionais" (ou do processo de desenvolvimento desigual) que emergem no âmbito da ampliação das cadeias agro-alimentares globais é central para se avançar na compreensão das causas que se colocam por trás fenômeno da expansão de forças brasileiras no Paraguai e, principalmente, do papel que as mesmas assumem no processo de desenvolvimento agrário e de integração do país com os mercados mundiais. 
5.

\section{A participação brasileira no desenvolvimento do agronegócio no Paraguai: trajetória e contexto atual}

O Paraguai se insere na cadeia global agro-alimentar contemporânea, junto com os demais países da região, assumindo, basicamente, a função de fornecedor de matérias primas agropecuárias. Essa situação se reflete em sua economia, onde a atividade agropecuária (produção primária) respondeu por $18,1 \%$ do PIB e os produtos agrícolas corresponderam a 58,5\% das exportações totais em 2012 sendo que a soja em grão, principal bem exportado ao longo da última década, respondeu por $21,7 \%$ das exportações. Naturalmente, as firmas transnacionais do agronegócio marcam presença no país. Por outro lado, a cadeia do agronegócio no Paraguai conta com um elemento peculiar, referente à participação de capitais e empresários brasileiros, grupo que se insere, principalmente, nas atividades de produção - sendo responsável, por exemplo, por mais da metade da soja produzida no país.

O objetivo central do presente capítulo é analisar essa configuração específica do agronegócio no Paraguai, buscando identificar o peso econômico dos principais atores envolvidos, principalmente, das empresas e dos produtores de origem brasileira, a fim de discutir seu papel no desenvolvimento da agricultura (capitalista) no país. Na elaboração da análise, levam-se em conta diferentes parâmetros, como: o comportamento dos fluxos de IED no país; a identificação das principais empresas do setor e suas formas de atuação; e as tendências em torno ao uso e apropriação da terra. A conjugação desses diferentes dados se faz necessária na medida em que, a presença brasileira no país constitui um fenômeno complexo e heterogêneo, que muitas vezes não consegue ser apreciado inteiramente nos dados econômicos oficiais.

A discussão sobre o papel dos capitais, empresários e produtores brasileiros no desenvolvimento do agronegócio no Paraguai precisa também considerar as dinâmicas sociopolíticas (de aliança e de conflitos entre os diferentes atores envolvidos) que acompanham a consolidação do modelo no país. Nesse sentido, após o estudo da estrutura econômica atual, a última seção do 
capítulo é dedicada a uma análise de episódios recentes e questões pontuais que evidenciam as dinâmicas de conflitos e alianças entre os principais atores envolvidos na atividade, apontando também alguns aspectos da intervenção dos governos de ambos os países em questão.

Em primeiro lugar, porém, realiza-se uma breve revisão histórica sobre o desenvolvimento da agricultura moderna (ou capitalista) no Paraguai - desde os anos 1960, sobretudo - no intuito de contextualizar melhor essas análises e de distinguir a trajetória da participação brasileira nesse processo - que diz respeito a um fenômeno que se desdobra há pelo menos quarenta anos.

\section{1}

O desenvolvimento da agricultura moderna no Paraguai (1960-1980)

O desenvolvimento do agronegócio e a expansão da presença brasileira no Paraguai são fenômenos que começaram a ganhar impulso a partir do final dos anos 1960, e início dos anos 1970, em meio a um contexto de reestruturação da economia mundial, marcado pelo aumento dos fluxos de investimentos estrangeiros para a região da América Latina. O volume de investimentos estrangeiros dirigidos ao Paraguai e a dinamização econômica que provocou foi tal que, esse momento é comumente considerado como o marco de uma "reinserção" do país ao sistema econômico mundial - desde a sua inserção “oficial” em 1870, após o final da Guerra da Tríplice Aliança ${ }^{99}$ - e como um ponto de inflexão na sua trajetória econômica.

No período imediato ao final da guerra, a entrada de investimentos estrangeiros no Paraguai se voltou, basicamente, à compra massiva de terras para a instalação de unidades produtivas de caráter extensivo e extrativo - para a exploração de madeira e erva mate, principalmente - adotando o formato de economias de enclave, e alimentando a consolidação do grande latifúndio (Herken, 1975; Hill, 1980; Glauser, 2009; Galeano 2011a). Essas unidades adquiriram grande peso na dinâmica econômica nacional. Por exemplo, a firma "La Industrial Paraguaya", uma das mais importantes do período, de origem

\footnotetext{
${ }^{99}$ Os processos econômicos que ganham espaço desde os anos 1970 marcam uma forte mudança na trajetória econômica paraguaia, sendo a mais significativa desde a sua "inserção oficial" no sistema capitalista mundial cem anos antes - quando, após o fim da Guerra da Tríplice Aliança (1865-1870), o país passou de ser uma economia relativamente fechada e isolada a ser uma economia aberta e integrada à economia mundial (Hill, 1980).
} 
anglo-argentina, chegou a ser proprietária de uma superfície que representava perto de $17 \%$ das terras da região Oriental do país ${ }^{100}$.

O impacto que a atuação dessas grandes empresas teve no processo histórico de desenvolvimento socioeconômico do Paraguai é indiscutível. Além de contribuir para a dinâmica de concentração de terras e exclusão social no país, o relativo isolamento das economias de enclave - que prejudicava a formação de um mercado interno mais dinâmico - e a própria lógica pela qual desenvolviam suas atividades - isto é, essencialmente extrativa e extensiva, sem a realização de reinvestimentos para o aprimoramento dos meios de produção - implicaram um fraco e lento desenvolvimento das forças produtivas paraguaias, tendência que persistiu, amplamente, ao longo dos primeiros cem anos da inserção do país no sistema capitalista mundial (Hill, 1980).

Esse aspecto explica, em grande parte, porque o Paraguai, à diferença de outros países da região, não contou com as condições materiais nem as forças políticas necessárias para a busca de formas alternativas de desenvolvimento como foi o caso das iniciativas de "substituição de importações" surgidas em outros países - no período em que a atividade agroexportadora entrou em declínio na região, por volta dos anos 1930 (Hill, 1980). Dessa forma, no advento da década de 1970, o Paraguai se distinguia por ser uma sociedade de forte base agrária e de escasso dinamismo (Fogel, 1988), situação que determinaria, decisivamente, o caráter da internacionalização de sua economia nas décadas seguintes.

Com efeito, a maior parte dos investimentos estrangeiros destinados ao Paraguai a partir dos anos 1970 se dirigiu, novamente, ao incentivo da atividade agrária, porém, com desdobramentos distintos: por um lado, identificou-se um processo crescente de "expansão das formas capitalistas de produção" fundamentalmente no setor agrário (Herken, 1975; Hill, 1980; Palau e Heikel, 1987); e por outro, verificou-se um aumento da participação de capitais e forças econômicas brasileiras nesse processo (Herken, 1975; Hill, 1980; Kohlhepp, 1984; Nickson, 1981).

\footnotetext{
${ }^{100}$ Além de "La Industrial Paraguaya", que possuía em torno a 2,6 milhões de hectares, citam-se outras empresas de grande peso como a "Barthe \& Co." e "La Societé Fonciere" (ambas de origem francesa) que, no inicio do século XX, detinham em torno de 1,12 milhões e 465 mil hectares, respectivamente. A Figura 15 (no Anexo) fornece uma ideia sobre as vastas superfícies ocupadas por essas firmas naquele período.
} 
De acordo com Hill (1982), no período de auge de crescimento da economia paraguaia (entre 1974-1978), o fluxo de capital estrangeiro aumentou significativamente, sendo canalizado predominantemente para o segmento agrícola-comercial: para a produção de grãos e óleo de sementes oleaginosas; para a exploração e produção florestal (madeira); e para o processamento de bens agrícolas, tanto para exportação (fibras de algodão e soja) como para o mercado interno. Muitas das grandes firmas estrangeiras que se instalavam no país também investiram na compra de grandes extensões de terra, que eram adquiridas, em geral, das antigas empresas do período das economias de enclave, implicando um processo de reconcentração de terras ${ }^{101}$. Em uma carta aos seus clientes, uma dessas empresas explicava os motivos que a levaram a investir no Paraguai para a produção de soja:

A fertilidade natural do solo é tão grande que não teremos que gastar grandes somas de dinheiro em fertilizantes, tal como fazemos nos Estados Unidos. A produtividade da terra é maior que a de outros países produtores de soja. Nossa soja fertilizada de forma natural terá um conteúdo de óleo superior ao da soja produzida em outras partes, fazendo-a desta forma mais cotizada. O custo do cultivo no Paraguai é menor do que nos Estados Unidos. Por exemplo, o trabalho no Paraguai é $90 \%$ mais barato que o trabalho de fazenda na América (Florida Peach Corporation, 1976 apud Nickson, 1981:127. Tradução própria).

Tem-se assim que, a internacionalização da economia e da agricultura paraguaia no novo contexto de ampliação dos fluxos de investimentos estrangeiros nos anos 1970 adquiriu características similares ao processo de internacionalização do século anterior. Contudo, também assumiu novos aspectos advindos, principalmente, do novo projeto de colonização agrária do governo paraguaio, colocado em marcha a partir dos anos 1960. O objetivo central desse projeto era promover a expansão da fronteira agrícola e a modernização da

\footnotetext{
${ }^{101}$ Hill (1980:58-61) cita algumas dessas firmas multinacionais que se instalaram no Paraguai comprando grandes extensões de terra: a Gulf and Western (54.000 ha.); a Florida Peach Corporation (17.000 ha.); a Empresa Fiduciaria Trasatlántica Alemana (16.000 ha.); a Paragro International S.A. (320.000 ha.); a Agropeco (70.000 ha.), entre outras. Essas empresas, em geral, instalavam unidades de produção e processamento de bens agrícolas para exportação. A aquisição de grandes superfícies por essas novas empresas implicou um processo de reconcentração das terras, isto é, a manutenção do forte caráter desigual da estrutura agrária do país, na medida em que, as grandes firmas passavam a controlar uma maior parte dos recursos, da produção e comercialização dos bens agrícolas, enquanto os pequenos e médios agricultores permaneciam em uma situação subordinada ou excluída dentro da nova dinâmica produtiva.
} 
produção $^{102}$. A região fronteiriça ao leste do país (ver Figura 8), cujos recursos naturais haviam permanecido amplamente inexplorados até então, tornou-se o alvo principal das novas políticas de desenvolvimento rural.

\section{Figura 8 - Mapa do Paraguai}

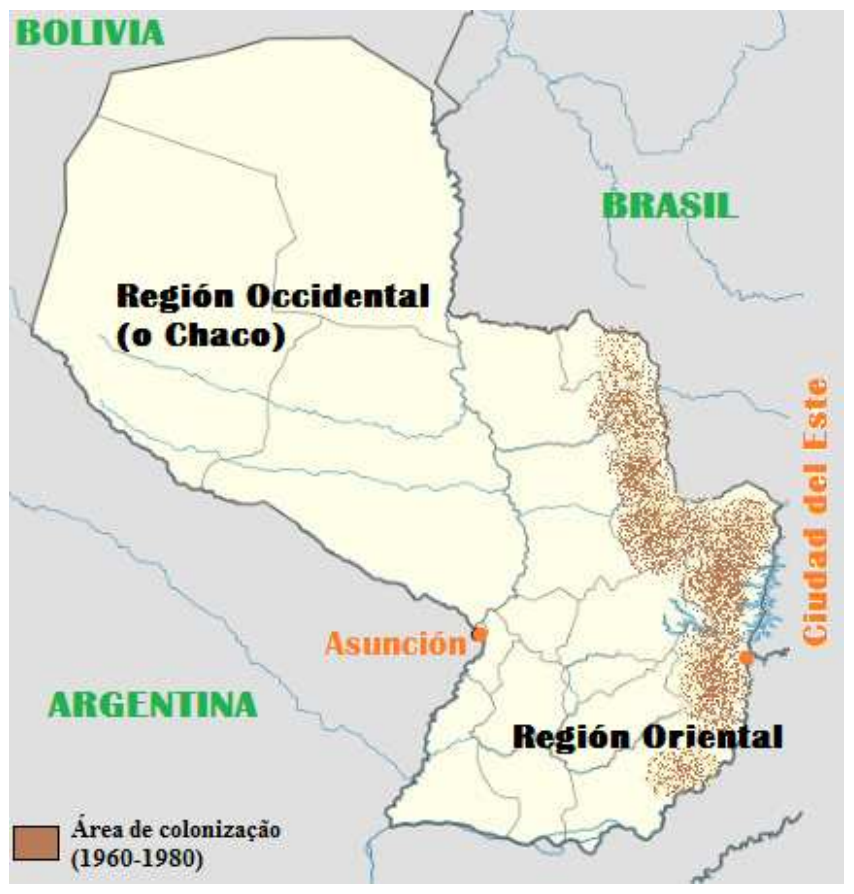

Fonte: Elaboração própria

$\mathrm{Na}$ prática, o projeto acabou sendo conduzido, majoritariamente, por colonos de origem brasileira, dando lugar à emergência da chamada "colonização brasileira". A análise dos fatores econômicos e políticos que levaram à emergência desse fenômeno no Paraguai (entre as décadas de 1960-1970) revela que se tratou de um processo complexo e heterogêneo, que recebeu incentivos de ambos os lados da fronteira, e que contou com a participação de atores de diversos portes econômicos ${ }^{103}$.

\footnotetext{
${ }^{102}$ Nesse contexto, o governo paraguaio fundou o Instituto de Bem-Estar Rural (IBR), para coordenar as iniciativas de colonização das novas áreas e cuidar da sua integração ao processo de desenvolvimento nacional.

${ }^{103}$ Ao longo do processo de colonização da região fronteiriça do país, Palau e Heikel (1987) identificaram pelo menos três lógicas diferentes de colonização e de expansão da fronteira agrícola - deixando em evidência a complexidade do processo: (1) a colonização pública, correspondente ao projeto oficial do governo executado pelo IBR; (2) a colonização privada, referida ao processo de colonização avançado por empresas imobiliárias privadas, antigos latifundiários paraguaios, grandes investidores brasileiros, etc.; (3) e a colonização espontânea, avançada por grupos de camponeses pobres, que ocupavam as terras na perspectiva de obter a adjudicação pelo Estado. Nos três casos, os autores identificaram a participação de migrantes brasileiros, seja como beneficiários, ou como agentes da colonização (sobretudo, na dinâmica de colonização privada).
} 
De um lado, o Estado paraguaio - na época, sob o governo do Gral. Alfredo Stroessner ${ }^{104}$ - buscava impulsionar um rápido crescimento econômico a partir dinamização da agricultura e de sua expansão para novas áreas, mais próximas dos principais polos de crescimento da região - no caso, para a região fronteiriça adjacente ao Brasil. Lançava-se assim a chamada "Marcha para o Leste", empreendimento que também recebeu apoio do governo brasileiro que, na mesma época, se encontrava promovendo a "Marcha para o Oeste", no contexto de expansão da fronteira agrícola em seu território (Palau e Heikel, 1987) ${ }^{105}$.

A estratégia de aproximação com regiões mais dinâmicas (como na fronteira com o Brasil) permitiria o aumento dos investimentos no país - como de fato aconteceu - incentivando não apenas o crescimento da produtividade agrícola e a consequente dinamização econômica, mas também o melhoramento da infraestrutura, principalmente, de transportes para escoamento dos produtos, complementando os esforços dos grupos empresariais paraguaios e do próprio governo no desenvolvimento da região fronteiriça ${ }^{106}$.

Nesse contexto, o ingresso de produtores rurais brasileiros - que contavam com uma maior experiência acumulada sobre os processos modernos de produção agrícola - foi se tornando um dos principais veículos da modernização da atividade agrícola na região fronteiriça do Paraguai. De fato, a atração desses migrantes passou a fazer parte da política de colonização oficial, sob a visão de que os colonos estrangeiros proporcionariam as ferramentas e as técnicas necessárias para o progresso no campo, conforme pronunciada pelo então ministro da instituição encarregada pela reforma agrária (o IBR):

\footnotetext{
${ }^{104}$ O Gral. Stroessner governou durante todo o período do regime militar instaurado no país, que durou de 1954 até 1989, sendo o mais longo da região.

${ }^{105}$ Ao longo das décadas de 1960-1970, a expansão da fronteira agrícola ganhou notoriedade em ambos os países, em meio a um contexto de aumento da demanda internacional por commodities agrícolas e de crescente entrada de IED para o desenvolvimento da agricultura na região - o contexto da "Revolução Verde" (ver capítulo dois). Conforme mencionado no capítulo anterior, no Brasil, a expansão da fronteira agrícola foi comandada pela soja que, inicialmente, era cultivada no sul do país (no estado do Rio Grande do Sul) e que, ao longo desse período, foi se expandindo para outros estados adjacentes - como Paraná e Santa Catarina - até a conquista da região centro-oeste. Nesse âmbito, desdobrou-se o PRODECER, um dos mais importantes empreendimentos do governo brasileiro orientado para a expansão da fronteira agrícola no país (ver capítulo três).

106 Os principais desenvolvimentos em termos de infraestrutura nesse contexto foram a pavimentação da rodovia entre Assunção e Ciudad del Este, e a construção da "Ponte da Amizade" (financiada pelo Brasil), que resultaram na habilitação de uma ligação (terrestre) direta para o Paraguai com os portos brasileiros de Paranaguá e Santos na costa atlântica.
} 
A migração de estrangeiros, especialmente daqueles que, dotados de cultura e tecnologia avançada, podem gerar com sua integração o melhoramento das técnicas, organização social e o avanço do desenvolvimento paraguaio, está contemplado pela própria Constituição da República (...). Estes migrantes contribuem ao progresso do país com seu aporte cultural e produtivo (...). Os colonos brasileiros forneceram novos produtos agrícolas e pecuários ${ }^{107}$.

Assim, o governo paraguaio, entre outras medidas, decidiu revogar (em 1963) a lei que proibia a venda de terras a compradores estrangeiros nas faixas fronteiriças do país - impedimento legal que havia vigorado desde o estabelecimento do Estatuto Agrário de 1940 (Glauser, 2009).

Diversos analistas, como Nickson (1981) e Palau e Heikel (1987), apontaram que o projeto de colonização da região fronteiriça do país, na verdade, não correspondia a um esforço genuíno do governo de impulsionar o desenvolvimento social e econômico do país, tratando-se mais de uma resposta de cunho político às crescentes tensões sociais pelo acesso à terra na região central do país ${ }^{108}$. Uma prova disso era o fato que o projeto de colonização carecia de um plano integral de desenvolvimento rural, que garantisse, por exemplo, o assentamento efetivo dos produtores paraguaios nas novas colônias. Nesse sentido, o relativo descaso do governo paraguaio com o programa de colonização também contribuiu para que os migrantes e colonos brasileiros ganhassem maior espaço na condução do processo $^{109}$.

Além das ações praticadas pelo governo paraguaio, a colonização brasileira ganhou fôlego em função do contínuo deslocamento de produtores brasileiros, que atravessavam a fronteira em busca de novas oportunidades de

\footnotetext{
${ }^{107}$ Pronunciamento registrado no documento do IBR "De la Reforma Agrária al Bienestar Rural" (s.d.), citado por Palau e Heikel (1987:25), tradução própria.

${ }^{108}$ Nickson (1981) e Palau \& Heikel (1987) explicam que, a colonização da região fronteiriça ao leste do Paraguai surgiu como solução para as tensões sociais em torno do acesso à terra na região central do país, onde a principal demanda para o estabelecimento de uma política de reassentamento dos produtores mais pobres e sem terra veio da parte dos grandes latifundiários da área. Dessa forma, a iniciativa de colonização do Estado esteve atrelada aos interesses dos grandes proprietários do país, o que resultou na manutenção da forte estrutura desigual da distribuição de terra ao longo do processo. Por outro lado, é preciso mencionar que o processo também se viu afetado por um forte componente de corrupção, contexto no qual muitas das terras que deviam ser destinadas à reforma agrária em andamento foram atribuídas a políticos, militares e empresários ligados ao governo, como forma de garantir a lealdade política.

${ }^{109}$ De acordo com Nickson (1981) e Kohlhepp (1984), em geral, os migrantes brasileiros chegavam ao Paraguai com melhores condições econômicas do que os pequenos produtores locais, conseguindo comprar e regularizar suas propriedades mais rapidamente, ficando habilitados a se beneficiar das políticas do Estado de apoio à colonização, ao passo que a maior parte dos colonos paraguaios não conseguia regularizar seus títulos, dificultando assim a sua permanência no território em questão.
} 
investimentos - movimento que estava estreitamente relacionado às mudanças estruturais em curso na agricultura no Brasil (desde os anos 1960) e às políticas de expansão da fronteira agrícola do governo brasileiro (Campos, 2013). Naquela época, o setor agrícola brasileiro estava passando por um acelerado processo de industrialização, a partir da instalação e expansão das indústrias de produção de máquinas agrícolas, de produtos veterinários, agroquímicos, e fertilizantes, que eram acompanhados por uma contínua expansão da produção agrícola. Conforme apontado no capítulo anterior, esses desenvolvimentos também estavam provocando tendências crescentes de concentração e oligopolização em todos os segmentos da cadeia, especialmente, das terras disponíveis para cultivo - que ganharam maior força nos estados do sul do Brasil - Paraná, Santa Catarina e Rio Grande do Sul (Campos, 2013).

Os primeiros fluxos de migrantes se constituíram, maiormente, de pequenos fazendeiros que, perante o avanço da agroindústria nos estados brasileiros vizinhos à fronteira paraguaia, perdiam competitividade e se viam obrigados a abandonar suas propriedades rurais, sendo então atraídos para o Paraguai em função da ampla disponibilidade de terras virgens, preços baixos, e incentivos fiscais e creditícios (Kohlhepp, 1984; Nickson, 1981).

Já na década de 1970, se verifica uma intensificação dos fluxos migratórios que, além das políticas públicas e das ações praticadas pelo governo paraguaio para atraí-los, era um reflexo da contínua expansão da agroindústria no Brasil $^{110}$. Por outro lado, a expansão da influência brasileira em outros segmentos econômicos não agrícolas também reforçou a migração de capitais, empresários e produtores rurais para a região fronteiriça paraguaia. Foi o caso da construção da repressa hidrelétrica de Itaipu, que atraiu grandes quantidades de capitais estrangeiros, assim como trabalhadores ${ }^{111}$.

\footnotetext{
${ }^{110}$ O período entre 1970 e 1981 se coloca como o momento de auge da migração brasileira principalmente, de pequenos e médios empresários familiares - estimando-se um fluxo em torno de 500.000 a 700.000 migrantes brasileiros ao longo desse período (Campos, 2013).

${ }^{111}$ A questão da construção e do aproveitamento (desigual) do potencial hidrelétrico de Itaipu é representativa da política expansionista do governo brasileiro no período em questão, mas também evidenciou os interesses do governo e do capital paraguaio. A esse respeito, Herken (1975) afirma que a construção da hidrelétrica representou uma clara concessão do governo paraguaio às exigências da indústria brasileira, optando assim por incentivar sua inserção econômica internacional sob o modelo agroexportador, isto é, sob a especialização na produção de bens primários para exportação.
} 
Progressivamente, empresas grandes e médias, seguindo a tendência dos primeiros colonizadores brasileiros, passaram a adquirir terras no Paraguai e a investir na agricultura mecanizada. Nesse contexto, Kohlhepp (1984:19) identificou um processo de "deslocamento bifásico": de um lado, colonos brasileiros que haviam sido expulsos de suas regiões provocavam o deslocamento dos colonos paraguaios; e por outro lado, a chegada de grandes empresas agrícolas começou a reproduzir o mesmo processo de expulsão de pequenos produtores - tanto brasileiros como paraguaios - que não conseguiam acompanhar os imperativos de competitividade causados pelo avanço da produção mecanizada.

Dessa forma, o Paraguai, e principalmente a região fronteiriça, experimentou profundas transformações que resultaram em um maior dinamismo econômico ao longo dos anos 1970, impulsionado, em grande medida, pela atividade agrícola. Os colonos brasileiros se colocaram entre os principais responsáveis pelo avanço da modernização agrícola, a partir das novas técnicas e tecnologias de produção trazidas junto com a migração. Por outro lado, o dinamismo do setor nesse período também se deveu à expansão das atividades de grandes empresas multinacionais, que aumentaram seus investimentos no país, conforme indicado anteriormente ${ }^{112}$.

A respeito da evolução da colonização brasileira e da questão migratória, resumidamente, podem distinguir-se três períodos distintos (Campos, 1999; 2013). O primeiro entre 1971-1981, coincidente com o auge econômico paraguaio, que corresponde ao período de maior fluxo de migrantes brasileiros, em sua maioria, pequenos e médios empresários familiares. O segundo entre 1982-1991, que marca um período recessivo na economia paraguaia, e também de esgotamento do projeto de colonização, a partir da liquidação das terras públicas. Nesse período, houve um fluxo migratório mais seletivo, de médios e grandes empresários, com maior capacidade produtiva e competitividade, colocando em marcha um processo de expulsão dos pequenos proprietários (paraguaios e brasileiros $)^{113}$. Estima-se que a população migrante reduziu significativamente nesse espaço de tempo, representando entre 200.000 e 100.000 brasileiros.

\footnotetext{
${ }^{112} \mathrm{O}$ cultivo de soja começa a ascender naquela época, de tal forma que, o Paraguai já se colocava como quinto maior exportador de soja no mundo (Nickson, 1981:126) e quarto produtor mundial (Kohlhepp, 1984:99).

${ }^{113}$ Nesse contexto, enquanto alguns colonos decidiram retornar ao Brasil, outros se dirigiram para regiões não fronteiriças do Paraguai.
} 
No último período, entre 1992-2001, tem-se a consolidação da estrutura produtiva capitalista, com a grande empresa agrícola e a incorporação, cada vez maior, de novas tecnologias de produção (sementes, fertilizantes, agroquímicos, e maquinário), acelerando o processo de expulsão dos pequenos proprietários e trabalhadores rurais, tendência que continua a se desdobrar até os dias atuais. Nesse período, estima-se que a população brasileira não deva ter superado o número de 200.000, mas é preciso apontar que existe uma ampla divergência quanto ao número total de brasileiros no país entre os diferentes registros ${ }^{114}$. Outra característica desse período mais recente é a abertura de novas áreas de migração e de expansão da fronteira agrícola, localizados na região ocidental (Chaco), e em áreas mais internas, isto é, não fronteiriças da região oriental do país.

Uma das principais implicações do processo de colonização brasileira foi a emergência da figura do "brasiguaio", nome comumente utilizado para designar os colonos brasileiros que se instalaram no Paraguai (tendo ou não adquirido a nacionalidade paraguaia) e aos seus descendentes nascidos no país. $\mathrm{O}$ aspecto que leva a categorizá-los como tal é que, apesar de serem paraguaios juridicamente, ainda se reconhecem como parte da comunidade brasileira, mantendo suas tradições culturais, e reivindicando frequentemente sua origem brasileira. Assim, quando se fala da presença brasileira no meio rural paraguaio atualmente, em geral, as análises se referem não apenas à comunidade de migrantes estrangeiros nascidos no Brasil, mas também ao grupo dos "brasiguaios"115.

\footnotetext{
114 De fato, o Censo Populacional mais recente, de 2002, indica que existiam no território paraguaio em torno de 83.000 brasileiros - considerando como critério ter nascido no estrangeiro (Souchaud, 2007:18). Isto diverge, amplamente, de estimativas realizadas por organizações como a Pastoral Migrante de ambos os países, ou do próprio Ministério de Relações Exteriores do Brasil, de que existem em torno de 350.000 brasileiros no Paraguai (Riquelme, 2005). A não existência de cifras exatas a respeito da quantidade de brasileiros no Paraguai reflete a complexidade e heterogeneidade do fenômeno - muitas vezes encarnado na figura do "brasiguaio". Em geral, a dinâmica desse grupo só consegue ser captada em estudos mais específicos sobre a evolução da colonização e da migração brasileira. Por outro lado, as cifras oficiais conseguem aproximar-se das estimativas secundárias ao se considerar outros critérios. Riquelme (2005:133), por exemplo, indica que ao tomar-se como critério o conjunto da população que declarou falar português no Paraguai no último Censo de 2002, tem-se um número de 326.496 pessoas.

${ }^{115}$ Existem vastas discussões sobre a figura e o significado do "brasiguaio", assim como uma grande dificuldade para definir o grupo empiricamente. Independentemente do verdadeiro tamanho desse grupo, ele tem um reconhecido peso social e político. Nesse sentido, embora os descendentes de colonos brasileiros e os brasileiros nacionalizados no Paraguai constituam uma massa heterogênea, a presente pesquisa considera a definição apresentada anteriormente sem fazer distinções, na medida em que permite continuar analisando os desdobramentos do processo de colonização e de expansão brasileira no país de uma forma geral.
} 


\section{2 O modelo do agronegócio no Paraguai: estrutura e dinâmicas atuais}

Nas últimas duas décadas, a integração do Paraguai à economia mundial e à economia brasileira em particular - se aprofundou seguindo o modelo colocado em marcha a partir dos anos 1970, isto é, por meio do contínuo desenvolvimento do modelo agroexportador, baseado na produção de commodities agrícolas para exportação - especialmente, de soja. A intensa abertura comercial vivenciada pelo Paraguai desde os anos 1990, a entrada de novos fluxos de investimentos estrangeiros orientados ao fomento da atividade agro-comercial, e a expansão da produtividade e da superfície de cultivo das commodities agrícolas evidenciam essa tendência.

A liberalização comercial do Paraguai foi intensa ao longo da década de noventa, em consonância com o processo de reestruturação econômica na região da América Latina como um todo ${ }^{116}$. Segundo Rojas (2011:23), o período de rápida liberalização aconteceu entre 1989 e 1995, quando as exportações, que equivaliam a $10 \%$ do PIB, e as importações que correspondiam a 14\% do PIB, passaram a representar $48 \%$ e $50 \%$ respectivamente. O predomínio de bens primários agrícolas nas exportações, ao longo desses anos, constata a tendência de reforço do padrão agroexportador. Em 1999, por exemplo, a soja em grão representou $41,5 \%$ do total das exportações, percentual que se mantém até hoje ${ }^{117}$.

Outra tendência que se reafirma ao longo das duas últimas décadas é o lugar do Brasil como um dos principais destinos, e também como lugar de origem, de bens comercializados pelo Paraguai. Ao longo desse período, o Brasil respondeu por perto da metade das exportações paraguaias, e representou em torno de um quarto das importações do país (ver a Tabela 18 na seção Anexo).

Além da liberalização comercial, o aprofundamento da integração produtiva do Paraguai com as economias regional e mundial, desde os anos 1990, foi marcado pela entrada de novos fluxos de IED. De acordo com Masi (2001), o aumento do IED no Paraguai na década de 1990 foi tal que as quantidades acumuladas nas três décadas anteriores - incluindo a década do "milagre" econômico paraguaio (1970) - representavam apenas um terço do total acumulado

\footnotetext{
116 Isto é, o período das "reformas neoliberais", que buscavam reascender o crescimento econômico dos países da região, após os anos de recessão generalizada na década de 1980.

${ }^{117}$ Dados da CEPALstat (2014).
} 
na década de $1990^{118}$. Um aspecto ressaltado pelo autor é que, nesse novo contexto, o setor agrícola (produção primária) foi perdendo peso como destino preferencial do IED, sendo superado por atividades do setor terciário (transporte, comunicações, bancos e comércio). De qualquer maneira, isso não significou que esses fluxos deixaram de ter impacto na dinâmica do setor primário, pois, as atividades de suporte à economia agroexportadora (como armazenagem, transporte e comercialização de cultivos) receberam grandes investimentos principalmente, por parte das transnacionais estadunidenses (Masi, 2013).

Desde 1990 até os dias atuais, identificam-se dois momentos diferentes no comportamento do IED no país: um primeiro ciclo de auge desses fluxos (19901998); e, após um breve período de recessão econômica (entre 1999-2002), um segundo momento de ascensão dos fluxos de IED - desde 2003 e, principalmente, a partir de 2008 (ver Figura 9). Ao longo desse segundo período (2003-2012), o setor terciário continuou como principal receptor dos investimentos estrangeiros, com destaque para os segmentos de comércio, transporte e comunicações. O setor industrial também passou a receber um montante significativo de IED, especialmente, para o processamento das matérias primas agrícolas (soja e carne), tendo as empresas transnacionais como principais protagonistas desses fluxos - de fato, EUA figura como a principal origem dos fluxos de IED na última década.

Figura 9 - Fluxos de IED no Paraguai (1990-2012)

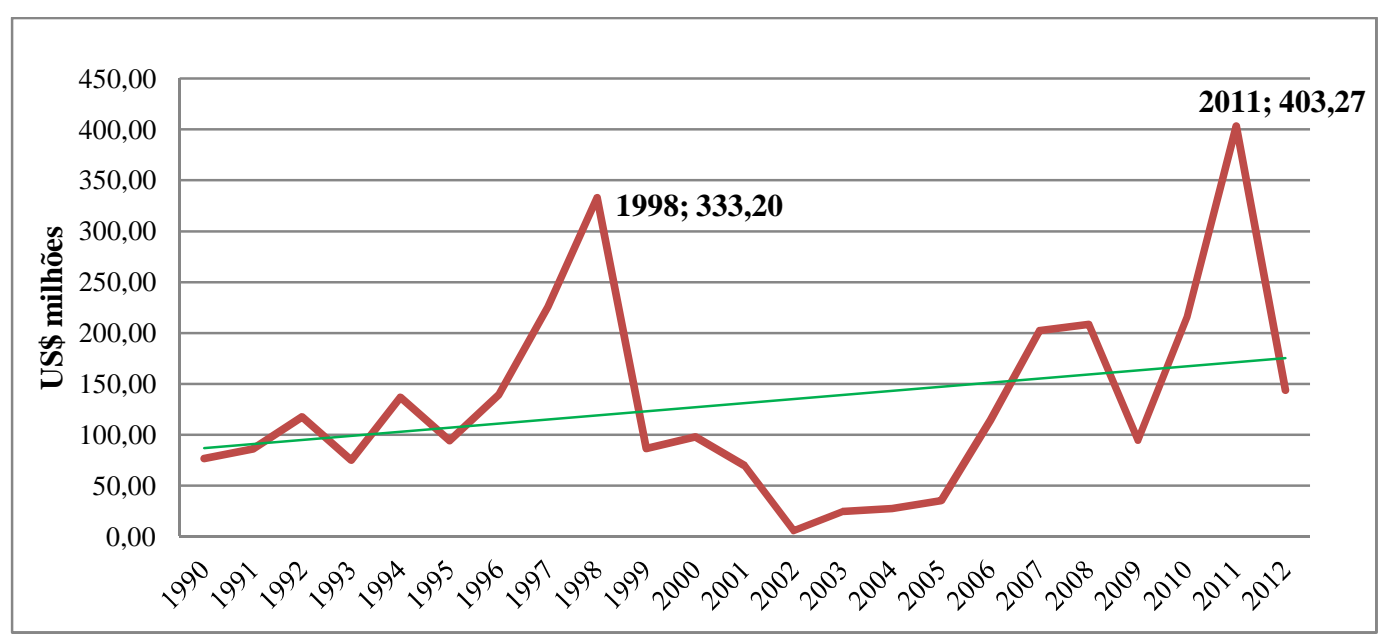

Fonte: Elaboração própria com base em dados da CEPALstat (2014)

\footnotetext{
${ }^{118} \mathrm{Na}$ década de 1970, o fluxo acumulado de IED (stock de IED) atingiu US\$ 147 milhões; e em 1980, o fluxo acumulado foi de US\$ 165 milhões. Já na década de 1990, o stock de IED chegou a US\$ 1.500 milhões (Masi, 2001:212).
} 
Analisando o comportamento dos fluxos de IED destinados para as atividades agrícola e agroindustrial, mais especificamente, verificam-se tendências similares àquelas identificadas no comportamento dos fluxos de investimentos na agricultura e na agroindústria a nível global (ver capítulo anterior), como a orientação preferencial dos mesmos para as atividades relacionadas à agricultura - isto é, para as atividades de logística ou de processamento dos bens agrícolas e, em menor medida, para o segmento da produção em si. Além disso, constata-se que esses investimentos na agricultura e atividades relacionadas no Paraguai assumem um peso relativamente alto com relação ao total de IED recebido pelo país - à diferença do que acontece em outros países da região ${ }^{119}$.

Dentro do conjunto das atividades da agricultura (setor primário) e da agroindústria no Paraguai, os investimentos estrangeiros diretos se concentraram, na última década, nos seguintes setores: no de elaboração de óleos que, no final de 2012, apresentou um stock de IED de US\$ 688.608, representando 14,3\% do estoque total de IED no país; na indústria de bebidas e tabaco, que respondeu por $7,7 \%$ do estoque total de IED no mesmo ano; nas atividades primárias da agricultura (2,9\%); na exploração florestal (1,4\%); e na produção (indústria) de carnes (1,0\%) (BCP, 2014b) - ver Tabelas 19 e 20, no anexo.

Outro aspecto notável sobre os fluxos recentes de IED no Paraguai é o peso que o capital brasileiro tem assumido, principalmente, a partir de 2008, colocando-se em segundo lugar após os capitais de origem estadunidense ${ }^{120}$. Além da presença de grandes empresas brasileiras - como a Camargo Corrêa e Votorantim, Banco do Brasil, Banco Itaú, a empresa de transporte aéreo TAM, Petrobrás e as processadoras de carne JBS e Minerva - nos últimos cinco anos pequenas e médias empresas têm sido responsáveis por uma ampla parcela dos Investimentos Diretos Brasileiros (IDB), em sua maioria, orientados ao setor

\footnotetext{
${ }^{119}$ De acordo com dados do Banco Central do Paraguai (BCP), o estoque de IED no final de 2012 para o conjunto de atividades do setor agro-alimentar foi de US\$1.330.483, representando $27,6 \%$ do estoque total de IED do país. Desse montante, o IED acumulado nas atividades agrícolas primárias representou apenas $4,3 \%$, ao passo que o investimento acumulado nas atividades agroindustriais correspondeu a 23,3\% do estoque total nesse ano (ver Tabela 20, no Anexo).

${ }^{120}$ De acordo com Rojas de Cerqueira (2012:7), no ano de 2007, o stock de investimentos dos EUA era de US\$ 860 milhões, enquanto o do Brasil era US\$ 340 milhões. Já em 2011, esse montante chegou a US\$ 1.740 milhões no caso dos EUA, e a US\$ 511 milhões no caso do Brasil, isto é, houve um crescimento de $116 \%$ e $50 \%$ respectivamente.
} 
industrial - com destaque para os setores de confecções e têxteis, couro e calçados, produtos químicos e plásticos (Rojas de Cerqueira, 2012) ${ }^{121}$.

No âmbito do presente trabalho, cabe destacar a expansão do IDB na indústria paraguaia da carne, pois diz respeito ao desenvolvimento do setor agroindustrial, estando também relacionado às dinâmicas do mercado de terras no país. Conforme visto no capítulo anterior, a indústria da carne no Brasil tem experimentado um crescimento exponencial nos últimos anos, dando lugar ao surgimento de grandes empresas - como a JBS-Friboi e a Minerva - que passam a se projetar internacionalmente. No Paraguai, a expansão dessas empresas processadoras de carne aconteceu por meio da abertura de filiais ou pela aquisição de plantas frigoríficas. Atualmente, o capital brasileiro controla mais da metade dos frigoríficos exportadores de carne no país ${ }^{122}$.

Em suma, a situação econômica atual do Paraguai representa um momento de aprofundamento do processo de integração produtiva do país com a economia mundial, e em especial com a economia brasileira, e de reforço do padrão agroexportador. As análises dos fluxos de comércio e de investimentos estrangeiros evidenciam esse panorama, mas são insuficientes para dar conta da variedade de dinâmicas que caracterizam o desenvolvimento (e a internacionalização) atual da agricultura paraguaia ${ }^{123}$. Nesse sentido, surge a necessidade de complementar essas análises com estudos específicos sobre a estrutura produtiva agrária do país - isto é, sobre a configuração da cadeia do

\footnotetext{
${ }^{121}$ A maior parte do IDB no setor industrial paraguaio tem por objetivo dirigir a produção ao mercado brasileiro. De fato, grande parte dos empresários opta por realizar suas inversões sob o "Regime de Maquila", que tem constituído uma política de atração de investimentos por parte do governo paraguaio. Para esses empresários brasileiros, os investimentos no Paraguai constituem uma forma de diminuir seus custos de produção e de manter a competitividade de seus produtos frente às importações brasileiras, principalmente, de produtos intensivos em mão de obra oriundos da China (Rojas de Cerqueira, 2012). Ainda que constitua um fenômeno incipiente, o aumento do IDB no setor manufatureiro paraguaio encontra-se em rápida ascensão, merecendo atenção especial nos próximos anos, a fim de verificar os seus desdobramentos em termos dos impactos na estrutura produtiva paraguaia e na sua relação econômica com o Brasil. A análise da evolução desse fenômeno, embora relevante, foge do escopo do presente trabalho que busca se aprofundar no estudo dos setores agrícola e agroindustrial. Sobre o regime de Maquilas no Paraguai (e o IDB nesse contexto) ver: Masi (2013); Rojas de Cerqueira (2012); REDIEX (2014).

${ }^{122} \mathrm{Em}$ conjunto, as firmas JBS e Minerva adquiriram quatro das maiores plantas frigoríficas do país nos últimos anos. A esse respeito, ver a notícia do jornal paraguaio $A B C$ Color (2012a): " $E l$ $60 \%$ de frigoríficos exportadores son controlados por firmas brasileñas".

${ }^{123}$ Frequentemente, as estatísticas oficiais sobre o comércio ou o IED não conseguem refletir completamente as tendências e dinâmicas identificadas nesse setor, por conta de aspectos como: o sub-registro dos fluxos de comércio (provocado pelo alto índice de contrabando de mercadorias); ou a dificuldade em detectar as nuances dos fluxos de investimentos estrangeiros, como no caso de investimentos realizados por imigrantes instalados no país (fenômeno que, conforme visto na revisão histórica, tem um papel decisivo no desenvolvimento do setor no Paraguai).
} 
agronegócio - uma vez que especificam, mais claramente, quais são os atores envolvidos, o tamanho da sua influência na dinâmica como um todo, e as decorrentes dinâmicas de hierarquização e subordinação econômica.

Portanto, as próximas duas subseções têm como propósito apresentar brevemente estudos mais específicos sobre: (1) a configuração da cadeia do agronegócio no país, isto é, os principais agentes envolvidos e a sua forma de atuação (na seção 5.2.1); (2) as dinâmicas específicas no segmento da produção, enfocando as tendências relacionadas ao uso e à apropriação da terra, que também evidenciam a consolidação do modelo de agricultura capitalista e a sua marcada orientação externa (na seção 5.2.2).

\subsection{1}

\section{A configuração da cadeia do agronegócio}

Em nível mundial e local, o agronegócio se organiza por meio de um conjunto de processos que vão além da atividade de produção em si (cultivo), referindo-se também às atividades de processamento (industrialização) dos bens agropecuários, às atividades comerciais e de apoio logístico, de fornecimento de insumos e serviços para a produção, e de distribuição final ao consumidor. Essa compreensão ampla do setor agrícola permite verificar as diferentes formas de inserção dos capitais e forças produtivas (nacionais e estrangeiras) na atividade.

Partindo dessa compreensão, Rojas (2009) ${ }^{124}$ constatou que as corporações transnacionais do agronegócio instaladas no Paraguai se inserem, fundamentalmente, nos processos de fornecimento de marcas próprias de insumos - sementes, agroquímicos, fertilizantes, etc. - na coleta e comercialização (incluindo a exportação) dos bens agrícolas produzidos, na industrialização de parte desses bens, e na importação de produtos finais elaborados (por exemplo, alimentos processados), concentrando uma ampla parcela dessas atividades. Outras empresas estrangeiras (de menor porte) e nacionais também participam colocando-se como complementadoras dessas atividades. Dessa forma, verifica-se que a consolidação do agronegócio no Paraguai segue a mesma tendência da configuração dessa cadeia a nível global, onde as firmas transnacionais se colocam como o núcleo do modelo.

\footnotetext{
${ }^{124} \mathrm{O}$ pesquisador paraguaio realizou um estudo original sobre os atores do agronegócio no Paraguai, mapeando as principais empresas transnacionais, estrangeiras e nacionais envolvidas.
} 
Já na atividade de produção em si, Rojas (2009) encontrou uma maior descentralização, no sentido de que um maior número de unidades econômicas empresas, cooperativas e produtores individuais - participam do processo em questão, sendo também, predominantemente, de origem local. Todavia, apesar de contar com a participação de um maior número de atores, dinâmicas de concentração e de desnacionalização também são fortes no segmento da produção. Embora as transnacionais não marquem uma presença direta na fase da produção, capitais regionais, e especialmente o brasileiro, se destacam neste âmbito. Essas tendências são percebidas na análise específica sobre a distribuição do uso e da propriedade da terra no país (a ser apresentada na seção 5.2.2).

A seguir, descreve-se em maior detalhe a configuração da cadeia do agronegócio no Paraguai e a lógica de atuação dos principais atores envolvidos firmas transnacionais, estrangeiras, nacionais e cooperativas - buscando evidenciar o peso da participação de cada grupo na estrutura, e ponderar a sua influência na dinâmica. O trabalho de Rojas (2009) é utilizado como base da análise, realizando-se uma atualização dos dados apresentados pelo autor ${ }^{125}$.

$\mathrm{Na}$ Tabela 11 pode verificar-se uma lista das principais corporações transnacionais do agronegócio presentes atualmente no Paraguai, e os processos da cadeia nos quais se inserem. No quadro, é possível constatar o fato de que as transnacionais presentes no país se orientam, fundamentalmente, às atividades relacionadas à produção, seja no fornecimento de insumos, na coleta e comercialização, ou na industrialização dos bens agrícolas. Nos segmentos da produção propriamente dita e na distribuição final (varejo), não se verifica a instalação direta de corporações transnacionais no país. Por sua vez, a maioria das

\footnotetext{
${ }^{125}$ Em seu trabalho, Rojas (2009) divide as empresas do agronegócio em quatro grupos: firmas transnacionais; empresas estrangeiras; empresas nacionais; e cooperativas de produção local. Além disso, as descreve em função dos segmentos da cadeia do agronegócio nos quais operam. $\mathrm{Na}$ medida em que esse trabalho foi realizado entre 2007 e 2008, sentiu-se a necessidade de atualizar os dados da amostra para a análise realizada na presente pesquisa. Nesse processo, foram mantidos os critérios de classificação das diferentes empresas utilizados pelo autor. Já na atualização da amostra de empresas, levaram-se em conta aspectos como: a posição dessas empresas no ranking de exportadores e importadores do Centro de Importadores do Paraguai (CIP) em anos mais recentes; a sua participação nos principais grêmios do setor; a sua projeção mundial, regional e local, evidente nas publicações jornalísticas, entre outros parâmetros. A combinação de diferentes critérios para a elaboração da amostra se deu em função das limitações para o acesso à informação sobre as atividades dessas empresas. No final, obteve-se uma amostra levemente diferente da apresentada por Rojas (2009), que pode ser entendida como um reflexo das mudanças acontecidas nesse período - como a instalação de novas empresas e o desaparecimento de outras. De qualquer forma, verificou-se que as considerações a respeito da estrutura e da dinâmica geral do agronegócio no Paraguai avançadas por Rojas (2009) persistem amplamente.
} 
empresas listadas está associada, diretamente, à cadeia de produção de cereais e grãos oleaginosos, especialmente, da soja.

Tabela 11 - Corporações transnacionais do agronegócio estabelecidas no Paraguai

\begin{tabular}{|c|c|c|c|c|c|c|}
\hline \multirow[b]{2}{*}{ Nome da empresa } & \multirow[b]{2}{*}{$\begin{array}{l}\text { País de } \\
\text { Origem }\end{array}$} & \multicolumn{5}{|c|}{ Principais segmentos de atuação } \\
\hline & & $\begin{array}{l}\text { Fornecim } \\
\text { ento de } \\
\text { insumos }\end{array}$ & Produção & $\begin{array}{c}\text { Coleta e } \\
\text { comercial } \\
\text { ização }\end{array}$ & $\begin{array}{l}\text { Industrializ } \\
\text { ação }\end{array}$ & $\begin{array}{l}\text { Districuiçã } \\
\text { o final } \\
\text { (varejo) }\end{array}$ \\
\hline ADM Paraguay & EUA & $\mathrm{X}$ & & $\mathrm{X}$ & $\mathrm{X}$ & \\
\hline Agritrade Paraguay & EUA & & & $\mathrm{X}$ & & \\
\hline Bayer S. A. & Alemanha & $\mathrm{X}$ & & & & \\
\hline Bunge Paraguay S.A & EUA & $\mathrm{X}$ & & $\mathrm{X}$ & $\mathrm{X}$ & \\
\hline Cargill Agropec. S.A.C.I. & EUA & $\mathrm{X}$ & & $\mathrm{X}$ & $\mathrm{X}$ & \\
\hline CHS del Paraguay S.R.L & EUA & $\mathrm{X}$ & & $\mathrm{X}$ & & \\
\hline $\begin{array}{lr}\text { Complejo Agroindustrial } \\
\text { Angostura } & \text { S.A. } \\
\text { (CAIASA)* } & \end{array}$ & EUA & & & $\mathrm{X}$ & $\mathrm{X}$ & \\
\hline ContiParaguay S.A. & $\begin{array}{l}\text { Holanda/Bé } \\
\text { lgica/EUA }\end{array}$ & & & $\mathrm{X}$ & $\mathrm{X}$ & \\
\hline Dow Agro. Paraguay & EUA & $\mathrm{X}$ & & & & \\
\hline JBS Paraguay & Brasil & & & $\mathrm{X}$ & $\mathrm{X}$ & \\
\hline $\begin{array}{l}\text { Louis Dreyfus } \\
\text { Commodities (LDC) }\end{array}$ & França & $\mathrm{X}$ & & $\mathrm{X}$ & $\mathrm{X}$ & \\
\hline Mosanto Paraguay & EUA & $\mathrm{X}$ & & & & \\
\hline Nestlé Paraguay & Suiza & & & & $* *$ & \\
\hline Nidera Paraguay & Holanda & $\mathrm{X}$ & & $\mathrm{X}$ & & \\
\hline Noble Paraguay & Hong Kong & $\mathrm{X}$ & & $\mathrm{X}$ & & \\
\hline Syngenta Paraguay & Suiza & $\mathrm{X}$ & & & & \\
\hline Unilever Paraguay & $\begin{array}{l}\text { Holanda/U } \\
\mathrm{K}\end{array}$ & & & & $* *$ & \\
\hline
\end{tabular}

Fonte: Adaptado de Rojas (2009:35)

No quadro, percebe-se também a tendência de integração vertical, isto é, o fato que algumas dessas empresas operam em mais de um segmento, implicando um maior controle do ciclo da produção. Por fim, é possível verificar que a maior parte dessas corporações é oriunda dos Estados Unidos (8) e da Europa (7). Uma empresa tem a sua matriz na Ásia (Hong Kong) e uma do Brasil ${ }^{126}$.

No segmento de fornecimento de insumos agrupam-se empresas que elaboram e comercializam marcas próprias - como a Bayer, Dow Agro, Monsanto e Syngenta - e empresas que comercializam e distribuem marcas de terceiros como ADM, Cargill, LDC, etc. A atuação dessas empresas consiste, basicamente,

${ }^{126}$ No presente capítulo, apresentam-se apenas as informações mais relevantes das empresas selecionadas, isto é, as que permitem verificar a atividade a que se dedicam e o peso que têm na estrutura do agronegócio local. Descrições mais detalhadas sobre a seleção de firmas transnacionais, e demais empresas que operam no agronegócio paraguaio, são apresentadas nas Tabelas 21, 22, 23 e 24, na seção Anexo, p. 186-200. 
na importação desses insumos, considerados de alta tecnologia e produzidos fora do país - como sementes, fertilizantes e agroquímicos. Assim, o crescimento das atividades do agronegócio no país pode ser verificado pelo contínuo aumento das importações dessas empresas. Em 2013, por exemplo, as onze corporações listadas que participam desse processo foram responsáveis pela importação de US\$ 376.766.414, representando 3,3\% do total das importações do país nesse ano ${ }^{127}$. Considerando que várias dessas empresas, principalmente as que fornecem marcas próprias, também operam por meio de empresas locais associadas, essas cifras podem ser maiores.

A participação das corporações transnacionais no agronegócio paraguaio é mais contundente no segmento de coleta e comercialização (exportação) dos bens agropecuários. Das 17 empresas listadas na Tabela 11, onze participam desses processos, contando com uma importante infraestrutura de armazenamento e de transporte próprias. Na Tabela 12, apresentam-se os montantes exportados por essas empresas nos últimos cinco anos, onde se percebe o constante crescimento dessas operações e a importante participação dessas empresas na dinâmica: em conjunto, essas empresas responderam por quase $50 \%$ das exportações totais do país em 2013.

Nesse grupo, ressalta-se o caso da Cargill que, em 2013, foi responsável por $26 \%$ das exportações totais do país, colocando-se em primeiro lugar no ranking de principais exportadores - elaborado pelo Centro de Importadores do Paraguai $(\mathrm{CIP})^{128}$. Com exceção da JBS - que opera no ramo de processamento e comercialização de carnes - o componente fundamental das exportações das demais empresas é a soja em grão, e também produtos derivados como óleo e farinha.

\footnotetext{
127 Já em 2009, essas empresas - sem contar com as de instalação mais recente, como a CHS, a Nidera, e a Syngenta (que operava indiretamente por meio de uma firma local) - totalizaram a soma de US\$ 144.347.966, representando 2,2\% das importações totais do país naquele ano. Ver Tabela 25, na seção Anexo.

${ }^{128}$ No mesmo ranking a empresa ADM se colocou no $2^{\circ}$ lugar; a firma Noble no $4^{\circ}$ lugar, seguida pelas firmas Louis Dreyfus $\left(5^{\circ}\right)$, a Bunge $\left(6^{\circ}\right)$, e a JBS $\left(7^{\circ}\right)(\mathrm{CIP}, 2014)$.
} 
Tabela 12 - Exportações totais das corporações transnacionais do agronegócio instaladas no Paraguai (2009-2013)

\begin{tabular}{|c|c|c|c|c|c|}
\hline \multirow{2}{*}{ Empresa } & \multicolumn{5}{|c|}{ Exportações Totais (US\$/FOB) } \\
\hline & 2013 & 2012 & 2011 & 2010 & 2009 \\
\hline ADM Paraguay & 941.020 .035 & 602.886 .300 & 660.241 .080 & 547.316 .127 & 413.111 .365 \\
\hline Agritrade & 10.333 .585 & 7.375 .121 & - & - & - \\
\hline Bunge S.A. & 243.019 .395 & 173.522 .926 & 240.878 .605 & 194.760 .092 & 101.876 .016 \\
\hline Cargill & 2.458 .909 .206 & 1.248 .389 .103 & 2.175 .697 .419 & 909.910 .815 & 606.296 .880 \\
\hline CHS del Paraguay & 70.890 .194 & - & - & - & - \\
\hline CAIASA & 90.080 .612 & - & - & - & - \\
\hline ContiParaguay & 41.340 .632 & 36.556 .053 & 63.497 .938 & 48.635 .503 & 60.719 .072 \\
\hline JBS Paraguay & 187.700 .809 & 127.707 .054 & 116.086 .039 & - & - \\
\hline \begin{tabular}{|lr} 
Louis & Dreyfus \\
Commodities(LDC) \\
\end{tabular} & 300.119 .564 & 166.527 .455 & 87.184 .201 & 137.705 .511 & 62.566 .332 \\
\hline Nidera Paraguay & 10.285 .412 & - & - & - & - \\
\hline Noble Paraguay & 313.160 .975 & 221.711 .619 & 261.271 .364 & 152.767 .516 & 85.476 .488 \\
\hline $\begin{array}{l}\text { (A) TOTAL } \\
\text { EMPRESAS }\end{array}$ & 4.666 .860 .418 & 2.584.675.630 & 3.604.856.646 & 1.991.095.563 & 1.330.046.152 \\
\hline (B) TOTAL PAÍS & 9.432.340.950 & 7.283.873.876 & 7.776.434.535 & 6.516.557.119 & 5.079.610.902 \\
\hline$\%(\mathrm{~A} / \mathrm{B})$ & $49,5 \%$ & $35,5 \%$ & $46,4 \%$ & $30,6 \%$ & $26,2 \%$ \\
\hline
\end{tabular}

Fonte: Elaboração própria com base em dados do CIP (2014) e do BCP (2014a)

No âmbito da industrialização, as empresas transnacionais presentes no país se dedicam, basicamente, ao processamento das commodities agrícolas (cereais e grãos oleaginosos). Nos últimos anos, essas empresas têm expandido a sua atuação no país, por meio de grandes investimentos para a ampliação de suas capacidades de processamento industrial. A ADM Paraguay, por exemplo, inaugurou, em 2013, uma nova planta de esmagamento de soja, a fim de elaborar maiores quantidades de ração animal e óleo vegetal para exportação. Ressalta-se também o consórcio formado pela Bunge Paraguay e a Louis Dreyfus (LDC) para a construção do Complexo Agroindustrial Angostura S.A. (CAIASA), que contou com financiamento do Banco Interamericano de Desenvolvimento (BID), sendo inaugurada também em 2013 (ABC Color, 2013b).

Nesse contexto de canalização dos esforços para o aumento da capacidade de processamento, constituiu-se, em 2006, a "Cámara Paraguaya de Procesadores y Exportadores de Oleaginosas y Cereales" (CAPPRO), entidade de grêmio que agrupa as principais empresas agroexportadoras dedicadas ao processamento de cereais e sementes oleaginosas - formada por onze empresas no total, entre as quais figuram a ADM, ContiParaguay, LDC, Noble, Bunge e Cargill (listadas na Tabela 11). De acordo com dados do grêmio, as integrantes respondem por $90 \%$ 
do volume de óleo e farinha de sementes oleaginosas produzido e exportado pelo país. Em 2012, o grupo afirma ter realizado investimentos acima de US\$ 400 milhões, no sentido de ampliar a capacidade de processamento (CAPPRO, 2014).

Ainda no segmento da industrialização, destaca-se o caso da Nestlé e da Unilever, que são empresas transnacionais dedicadas à elaboração de alimentos industrializados - e de outros bens de consumo básico, no caso da Unilever - que têm suas plantas industriais em outros países da região, e operam no Paraguai importando seus produtos finais elaborados.

Finalmente, no grupo das transnacionais, cabe distinguir o caso da brasileira JBS, que se destaca na cadeia de produção de carnes. A JBS é uma empresa de transnacionalização relativamente recente que, embora não tenha (ainda) o alcance mundial ou a rentabilidade das demais empresas listadas no quadro, foi considerada nesse grupo por conta de sua ampla expansão global nos últimos anos. No Paraguai, essa expansão se concretizou pela aquisição de dois dos principais frigoríficos do país: o Frigorífico San Antonio, em 2009, e a Indústria Frigorífica Paraguaya (IFPSA), em 2010 (ABC Color, 2012a). Dessa forma, a JBS passou a controlar uma parcela importante da industrialização da carne no Paraguai, além de se colocar entre os principais exportadores do país ( $7^{\circ}$ lugar em 2013). Entre 2011 e 2013, as suas exportações aumentaram em torno de $62 \%$ (ver Tabela 12).

Outras empresas estrangeiras - em geral, de menor porte que as transnacionais - também marcam presença importante na dinâmica do agronegócio no Paraguai. Com base na amostra de empresas selecionadas para representar esse grupo (Tabela 22, na seção Anexo), verifica-se que há uma maior participação de capitais da região do Cone Sul: das dez empresas selecionadas, cinco têm origem $\operatorname{argentina}^{129}$, e duas são brasileiras ${ }^{130}$. Diferentemente das

\footnotetext{
129 São: a ARCORPAR (do segmento de elaboração de alimentos), que opera no Paraguai importando suas marcas; a Companhia Paraguaia de Grãos (COPAGRA), de processamento e comercialização (exportação) de óleos vegetais; a empresa de "Desarrollo Agrícola del Paraguay (DAP)" e a firma "Tierra Roja S.A." (do grupo "Los Grobo", líder dos agronegócios na região), que realizam atividades de cultivo e comercialização de grãos, especialmente de soja; e a empresa Vicentin S.A., que se dedica à coleta e comercialização (exportação) de soja, a fim de atender a demanda de suas matrizes na Argentina. Para mais detalhes sobre essas empresas, ver Tabela 22.

${ }^{130}$ São: O Grupo Minerva, do setor de produção e comercialização de carnes, que estendeu a sua presença no Paraguai recentemente, por meio da aquisição de duas plantas frigoríficas; e a cooperativa de produção LAR S.R.L., que opera no país fornecendo serviços aos produtores agrícolas (de coleta e comercialização de grãos, e de fornecimento de insumos e serviços técnicos). Para maiores detalhes sobre essas empresas, ver Tabela 22.
} 
corporações transnacionais, um maior número de empresas deste grupo incursiona no segmento da produção (cultivo): metade das empresas listadas tem atuação direta nessa área - o que significa que devem investir na aquisição de importantes superfícies de terra para tal ${ }^{131}$.

O segmento da cadeia de produção que atrai o maior número de empresas neste grupo (nove em total) é o de coleta e comercialização (exportação) dos bens agropecuários, o que deixa em evidência a lógica que predomina nos processos de instalação dessas empresas no país (similar àquela das firmas transnacionais): isto é, orientadas, preferencialmente, para as atividades relacionadas à produção primária. Com efeito, da mesma forma que no grupo anterior, o principal componente das atividades de comercialização destas empresas é a soja ${ }^{132}$.

Finalmente, quatro empresas realizam atividades no segmento da industrialização, a partir de diferentes produtos: enquanto a firma argentina COPAGRA se dedica à industrialização de soja, a brasileira Minerva atua na industrialização de carne, e a japonesa Shirosawa trabalha no processamento de sésamo e amendoim. A firma ARCORPAR, filial da empresa argentina ARCOR, que se dedica à elaboração de alimentos industrializados, distingue-se por operar no país sob o mesmo formato das empresas agro-alimentares citadas anteriormente - a Nestlé e a Unilever - isto é, importando os produtos finais que foram industrializados ou elaborados em outros países.

Tomando-se os dados das cinco maiores exportadoras desse grupo de empresas em 2013, é possível ter uma noção de seu peso na atividade agroexportadora paraguaia. São elas: a Vicentin ( $8^{\circ}$ no ranking do CIP); a Minerva, cujas operações são registradas em nome de seus dois frigoríficos locais, Frigomerc ( $10^{\circ}$ no ranking do CIP) e Friasa ( $16^{\circ}$ no ranking do CIP); a Copagra ( $22^{\circ}$ no ranking do CIP); a empresa LAR ( $38^{\circ}$ no ranking do CIP); e a DAP ( $41^{\circ}$ no ranking do CIP). Em conjunto, essas empresas foram responsáveis por 5\% do valor total exportado pelo Paraguai em 2013 (ver Tabela 26, em anexo), que

\footnotetext{
${ }^{131}$ No caso de algumas dessas empresas, foi possível conferir a extensão aproximada de suas operações (conforme declarações em suas páginas web): a empresa de origem argentina "Desarollo Agrícola del Paraguay (DAP)" trabalha em uma superfície total de 22 mil hectares, dos quais 11 mil são próprios e o restante é alugado; a "Paraguay Agricultural Corporation" (PAYCO), de origem portuguesa, realiza diversas atividades agrícolas somando uma área em torno de $135 \mathrm{mil}$ hectares; e a argentina "Tierra Roja S.A." cultiva soja em uma área em torno de 22 mil hectares.

${ }^{132}$ Com exceção de duas empresas: a brasileira Minerva, que se insere no setor de carnes, e a japonesa Shirosawa, que trabalha com o cultivo e processamento de sésamo e amendoim.
} 
representa uma percentagem significativa, porém, muito menor do que o conjunto das firmas transnacionais.

Em nível local, inúmeras empresas participam da dinâmica do agronegócio no país, sendo impossível no contexto do presente trabalho realizar um mapeamento completo das mesmas. Entretanto, por meio de uma amostra de 22 empresas que mostram ter um forte peso na dinâmica, é possível traçar algumas considerações (ver Tabela 23, na seção Anexo). Neste âmbito, Rojas (2009) apontou um aspecto relevante a ser levado em conta, referente ao fato que muitas dessas empresas, embora tenham sido constituídas no país, estão total ou parcialmente vinculadas a capitais ou empresários estrangeiros - especialmente, brasileiros ou "brasiguaios" - o que dificulta determinar, nesses casos, o grau de relação ou de transferência de recursos com os países a que aparecem vinculados $^{133}$.

$\mathrm{Na}$ amostra de 22 empresas (de origem "local"), doze teriam a sua propriedade vinculada a capitais ou empresários de outros países - isto é, metade das empresas selecionadas, sendo uma com a Argentina, e o restante com o Brasil. A empresa que tem vínculo com capitais argentinos é a Molinos Harineros del Paraguay, que tem como co-proprietária a empresa argentina Rinehart S.A. Já no caso das empresas vinculadas ao Brasil, a maior parte tem em comum o fato de que foram fundadas por migrantes brasileiros ou "brasiguaios".

Cita-se, por exemplo, o caso da "Agrotec", empresa dedicada ao fornecimento de insumos agrícolas (agroquímicos) e de serviços técnicos aos produtores locais, que foi fundada pelo brasileiro Túlio Luiz Neves Zanchet, quem decidiu investir no Paraguai no início dos anos 1990, ao perceber a oportunidade de negócio gerada pela falta de fornecedores de insumos técnicos no campo paraguaio ${ }^{134}$. Atualmente, a empresa tem uma atuação importante no segmento de comercialização e fornecimento de insumos e serviços agrícolas, realizando também atividades de coleta e comercialização de grãos.

\footnotetext{
${ }^{133}$ No presente trabalho, a dificuldade em determinar a parcela exata de capital estrangeiro na estrutura proprietária dessas empresas é agravada em função da limitação ao acesso a essas informações. Sendo assim, na lista selecionada, são consideradas empresas com propriedade "vinculada" a capitais estrangeiros aquelas que mostram explicitamente - em declarações nas respectivas páginas web ou em entrevistas e declarações de seus diretivos publicadas em outros meios - estar atrelada a diretivos ou proprietários estrangeiros.

${ }^{134}$ Informação disponível em entrevista realizada ao presidente do Grupo Agrihold - do qual Agrotec faz parte - Túlio L. Neves, publicada na revista institucional "Inform Agrotec", disponível em: http://issuu.com/agrotec/docs/informagrotec_16. Acesso em: 23 de março de 2014.
} 
Ressalta-se também o caso das empresas "Agrofértil" - que realiza atividades de fornecimento de insumos (importando e comercializando sementes, fertilizantes e agroquímicos), e de coleta e comercialização de grãos - e da “Tecnomyl”, dedicada à produção e comercialização de agroquímicos e fertilizantes, que têm como presidente o brasileiro José Marcos Saraiva. De acordo com depoimentos do empresário, a decisão de investir no agronegócio paraguaio aconteceu em função de seu potencial de crescimento, assim como dos menores custos e barreiras burocráticas ${ }^{135}$.

Todavia, o principal exemplo de empresa constituída por migrantes brasileiros corresponde ao empresário Tranquilo Favero, que emigrou do Brasil para o Paraguai nos anos 1970 e que, desde então, realizou um conjunto de empreendimentos agropecuários que atualmente se reúnem no "Grupo Favero" 136. Hoje, o grupo se coloca como uma das maiores empresas agroexportadoras do país, atuando em diversos segmentos da cadeia de produção por meio de suas diferentes empresas. O Grupo Favero se constitui de nove empresas, que atuam desde o fornecimento de insumos agrícolas (agroquímicos e maquinário), passando pela produção e exportação de grãos oleaginosos (soja, principalmente) e pela criação de gado, até as atividades de coleta, transporte e exportação da produção agrícola ${ }^{137}$. Em função de sua ampla variedade de atividades e empresas, o grupo também se apresenta como um importante proprietário de terras, sendo alvo frequente de denúncias por parte dos pequenos produtores, campesinos sem terra e organizações sociais, que questionam a legalidade de suas propriedades.

As empresas "brasiguaias", citadas anteriormente, ganham relevância no grupo de empresas em questão na medida em que têm uma participação

\footnotetext{
${ }^{135}$ O empresário José Marcos Saraiva fez esses depoimentos em um seminário da Federação das Indústrias do Estado de São Paulo (FIESP), onde falou sobre a sua experiência e as vantagens de se investir no Paraguai. A esse respeito, ver FIESP (2013a).

${ }^{136}$ Atualmente, o empresário já possui a nacionalidade paraguaia. Tranquilo Favero também é conhecido no Paraguai como o "rei da soja", pois suas empresas estão entre as maiores produtoras e exportadoras desse cultivo, além de ser proprietário de grandes extensões de terra.

137 As empresas do Grupo Favero são: A "Agro Silo Santa Catalina" e a "Agrotoro S.A.", dedicadas à produção, coleta e exportação de grãos (principalmente, soja), e também à comercialização de insumos agrícolas; a "AKTRA S.A.", dedicada à elaboração e comercialização de agroquímicos; as fazendas "Ganadera Campo Bello", "Ganadera Forestal Santa Catalina" e "Ganadera San Liberato", dedicadas à criação de gado; a empresa "Sementes Verónica", voltada à pesquisa, desenvolvimento, produção e distribuição de sementes oleaginosas, possuindo convênios com entidades como a instituição brasileira de pesquisa EMBRAPA, e a transnacional Syngenta; a empresa Totem S.A., que é o porto privado do grupo; e finalmente, a empresa Trafa S.A., que comercializa máquinas para a produção agrícola, representando marcas estrangeiras como a New Holland). Para descrições mais detalhadas, ver Tabela 23 em anexo.
} 
significativa na dinâmica agroexportadora. Em conjunto, essas empresas exportaram o valor de US\$281.356.135 em 2013, correspondente a 3\% do valor total exportado pelo país, e importaram US\$294.935.447, que representou 2,6\% do valor total importado pelo Paraguai ${ }^{138}$. Dessa forma, essas empresas se colocam atualmente entre os principais exportadores e importadores do país ${ }^{139}$.

Deixando de lado a questão sobre os vínculos secundários de algumas das empresas locais selecionadas, se faz relevante delinear as suas formas de atuação na dinâmica do agronegócio paraguaio. Dentre as 22 empresas da amostra, tem-se que, onze operam fornecendo insumos - como sementes, agroquímicos e fertilizantes, e também máquinas (veículos e implementos) agrícolas. Em geral, essas empresas atuam importando marcas de terceiros e comercializando-as no mercado local ${ }^{140}$. Cinco empresas atuam diretamente na produção dos cultivos e/ou na atividade pecuária; 18 empresas realizam atividades de coleta e exportação dos bens agrícolas (grãos e produtos derivados como óleo e farinha) ${ }^{141}$; e oito empresas realizam a industrialização dos produtos agrícolas.

Por fim, tem-se o grupo das cooperativas de produtores rurais (Tabela 24, na seção Anexo). Das doze cooperativas listadas - que representam as maiores cooperativas de produção do país - seis se dedicam ao ramo dos produtos pecuários (abrangendo as atividades de criação de gado, produção e processamento de carnes, embutidos e produtos lácteos), e o restante se destaca na produção agrícola (especialmente, de grãos oleaginosos e cereais). Além da produção, essas cooperativas realizam atividades de apoio aos seus sócios produtores, oferecendo serviços de comercialização de insumos para a produção, e de coleta e comercialização dos bens produzidos. Metade delas - basicamente, as que se dedicam à pecuária - também realiza atividades de industrialização. Em conjunto, essas cooperativas têm uma participação significativa na dinâmica

\footnotetext{
${ }^{138}$ Conferir Tabela 27, em anexo.

139 De acordo com o ranking elaborado pelo CIP (2014), no ano de 2013, essas empresas se colocaram nas seguintes posições: Agrotec, $45^{\circ}$ (exportações) e $15^{\circ}$ (importações); Agrofértil, $17^{\circ}$ (exp.) e $18^{\circ}$ (imp.); Tecnomyl, $55^{\circ}$ (exp.) e $25^{\circ}$ (imp.); e as empresas do Grupo Favero, Agro Silo Santa Catalina, $9^{\circ}$ (exp.), e Agrotoro S.A., $64^{\circ}$ (exp.).

${ }^{140} \mathrm{Em}$ função do alto valor agregado dos produtos comercializados, essas empresas têm uma participação relevante na dinâmica das importações. Em 2013, o valor importado pelo conjunto das 11 empresas representou 4\% do total das importações do país (ver Tabela 28, em anexo).

141 Em conjunto, essas 18 empresas têm uma participação significativa da dinâmica das exportações, tendo respondido por 5,3\% das exportações totais do país em 2013 (ver Tabela 29 em anexo).
} 
agroexportadora, respondendo por 3,8\% do valor total das exportações do país em 2013 (ver Tabela 30 em Anexo).

Um aspecto relevante a respeito dessas cooperativas é que várias delas tiveram a participação, total ou parcial, de imigrantes na sua conformação inicial. Primeiramente, destacam-se as que foram fundadas por imigrantes menonitas (de origem europeia e canadense), que chegaram ao país na primeira metade do século XX: As cooperativas Chortitzer, Fernheim e Neuland, localizadas na região ocidental do país (Chaco), que atualmente são líderes na produção de carne e produtos derivados para o mercado local, colocando-se também entre os principais exportadores do país ${ }^{142}$; e as cooperativas Volendam e Friesland, de menor porte, que se localizam na região oriental. Têm-se também cooperativas que contaram com a participação de colonos brasileiros na sua fundação, como a "Cooperativa Agropecuária Pindó” e a "Cooperativa de Produção Agroindustrial Santa Maria”.

Em suma, os dados analisados ao longo desta subseção apontam para uma configuração da dinâmica agroexportadora centrada na atuação das firmas transnacionais do agronegócio, que controlam uma ampla parcela do processamento e comercialização (exportação) dos bens agropecuários, e também o fornecimento de insumos utilizados na fase da produção. As demais firmas estrangeiras, assim como as empresas nacionais e cooperativas de produção, embora cumpram uma função significativa a nível local, se inserem a partir desse núcleo definido pelas transnacionais.

Conforme apontado por Rojas (2009), é notável o fato de que as corporações transnacionais não participam diretamente das atividades de produção agrícola. Dessa forma, nesse segmento abre-se maior espaço para a participação de outros capitais estrangeiros (especialmente, regionais) e de capitais e atores locais. A esse respeito, Rojas (2009:73) indicou que:

[...] na prática, os produtores são apenas uma engrenagem entre o processo de fornecimento e coleta da produção, na medida em que as corporações lhes

\footnotetext{
${ }^{142}$ Conforme o ranking elaborado pelo CIP (2014), em 2013, essas empresas se colocaram nas seguintes posições entre os exportadores: Fernheim $\left(11^{\circ}\right)$; Chortitzer $\left(14^{\circ}\right)$ e Neuland $\left(36^{\circ}\right)$. Por outro lado, em 2007, as três cooperativas se juntaram para formar a "Central de Cooperativas de Producción (CENCOPROD)", a fim de levar adiante projetos em comum. O primeiro foi a instalação de uma planta processadora de couro bovino, que começou suas atividades em 2009. Já em 2013, o grupo inaugurou outra planta industrial para a elaboração de farinha de carne e ossos. Informação disponível em: http://www.cencoprod.com.py/. Acesso em: março de 2014.
} 
entregam os insumos e posteriormente recebem a produção, em troca de um pequeno ganho, que para as transnacionais é apenas um custo de produção no processo que lhes gerará enormes dividendos, na etapa da comercialização ou processamento das matérias primas agrícolas - Tradução própria.

Assim, pode-se argumentar que na configuração do agronegócio no Paraguai se estabelece uma hierarquização entre os diferentes segmentos da cadeia de produção - que nada mais é do que o reflexo da configuração do agronegócio a nível mundial - com as transnacionais controlando a maior parte das atividades relacionadas à produção agropecuária (de maior rentabilidade), e com as demais empresas e produtores individuais se inserindo de forma secundária nessas atividades, e respondendo pela maior parte das atividades de produção efetiva dos cultivos (segmento que, no caso, constitui o elo mais subordinado da cadeia).

Em termos sociopolíticos, essa divisão de tarefas resulta em uma presença "menos visível" das transnacionais no país, que se mantêm distantes dos (frequentes) conflitos que emergem em torno da expansão da produção empresarial - que, geralmente, acontecem entre os grupos de campesinos afetados negativamente pelo fenômeno e os grandes produtores e empresas que realizam a produção mecanizada e em grande escala (Rojas, 2009).

Ainda a respeito da atuação das empresas estrangeiras (tanto das transnacionais quanto das estrangeiras de menor porte), cabe mencionar a sua contribuição para o reforço da lógica de "intercâmbio desigual" que caracteriza as relações comerciais do Paraguai com os demais países. Conforme Rojas (2009), isso se verifica na forma em que essas empresas transnacionais e estrangeiras se instalam no país, limitando-se a processar e exportar bens de menor valor agregado (grãos, farinhas e óleos), e a importar produtos de maior valor agregado (como alimentos elaborados; e também os insumos tecnológicos utilizados na produção).

Por fim, os espaços ocupados pelos capitais e empresas de origem brasileira ao longo da cadeia, a primeira vista, parecem limitados, por conta da ampla dominação das firmas transnacionais - identificando-se alguns exemplos pontuais, como o caso da cooperativa LAR S.R.L. (no âmbito da cadeia de produção de soja). Considerando outros setores, como o de produção e processamento de carne, tem-se que a transcendência dos capitais e empresas 
brasileiras é maior - conforme visto pela forte expansão da JBS e da Minerva no país. Todavia, indo além das formas tradicionais de internacionalização de capitais e empresas (e dos dados oficiais de comércio ou IED), verifica-se que a presença brasileira se destaca por meio de outras modalidades, como é o caso da instalação de empresas de serviços ao agronegócio por migrantes brasileiros e "brasiguaios" - situação vinculada ao processo histórico de colonização brasileira que ganhou forma na região fronteiriça no Paraguai nos anos 1960-1970. Por esse mesmo esquema, tem-se que a presença brasileira também é forte nas atividades primárias de produção, conforme será apresentado na seguinte seção, que analisa as dinâmicas específicas nesse segmento.

\section{2 .2}

\section{Concentração e "estrangeirização" da terra}

As dinâmicas relacionadas à distribuição do uso e da propriedade da terra refletem, nitidamente, as mudanças acontecidas na estrutura agrário-produtiva paraguaia nas últimas décadas, caracterizadas pelo avanço do modelo da agricultura capitalista (intensiva em capital e energia, e orientada para a produção em grande escala de commodities agrícolas para exportação). O estudo específico dessas dinâmicas permite vislumbrar aspectos mais sutis e complexos a respeito da dinâmica geral do agronegócio no país.

Por exemplo, até agora, o capítulo evidenciou o importante papel dos capitais estrangeiros na instalação e consolidação do modelo do agronegócio no país, apontando que, em geral, os fluxos de IED e as firmas transnacionais não participam diretamente das atividades primárias de produção agropecuária. Todavia, os dados sobre a distribuição do uso e da propriedade da terra mostram que também existe uma forte participação de capitais e de empresários estrangeiros nessas atividades - especialmente, de origem brasileira.

Por outro lado, as análises desses dados permitem verificar o forte grau de internacionalização da agricultura paraguaia para além da questão da origem dos capitais investidos ou atores envolvidos, ressaltando aspectos como a crescente orientação para a produção de bens agrícolas comerciais (commodities) voltados para exportação, e a consolidação da grande unidade agrícola. 
Dessa forma, a presente subseção tem por objetivo analisar os padrões de distribuição no uso e na propriedade da terra no Paraguai. Nesse âmbito, um dos principais parâmetros do grau de consolidação do agronegócio no Paraguai, ao longo das últimas décadas, é o crescimento do cultivo da soja no país. De acordo com o último Censo Agropecuário Nacional (CAN), realizado entre 2007 e 2008, a produção de soja aumentou em 511,2\% entre 1991 e 2008 (MAG, 2008:56). Por sua vez, a superfície destinada ao cultivo aumentou em 345,8\%, no mesmo período. Em 2008, $73 \%$ das terras destinadas para cultivo estavam ocupadas pela produção de soja. Na Figura 10, pode observar-se esse crescimento exponencial do cultivo da soja, tanto em termos de superfície (hectares) quanto de produção (toneladas). Nessa trajetória, os números registrados em 2013 representam recordes inéditos de produção e superfície cultivada.

Figura 10 - Expansão da superfície e produção de soja no Paraguai

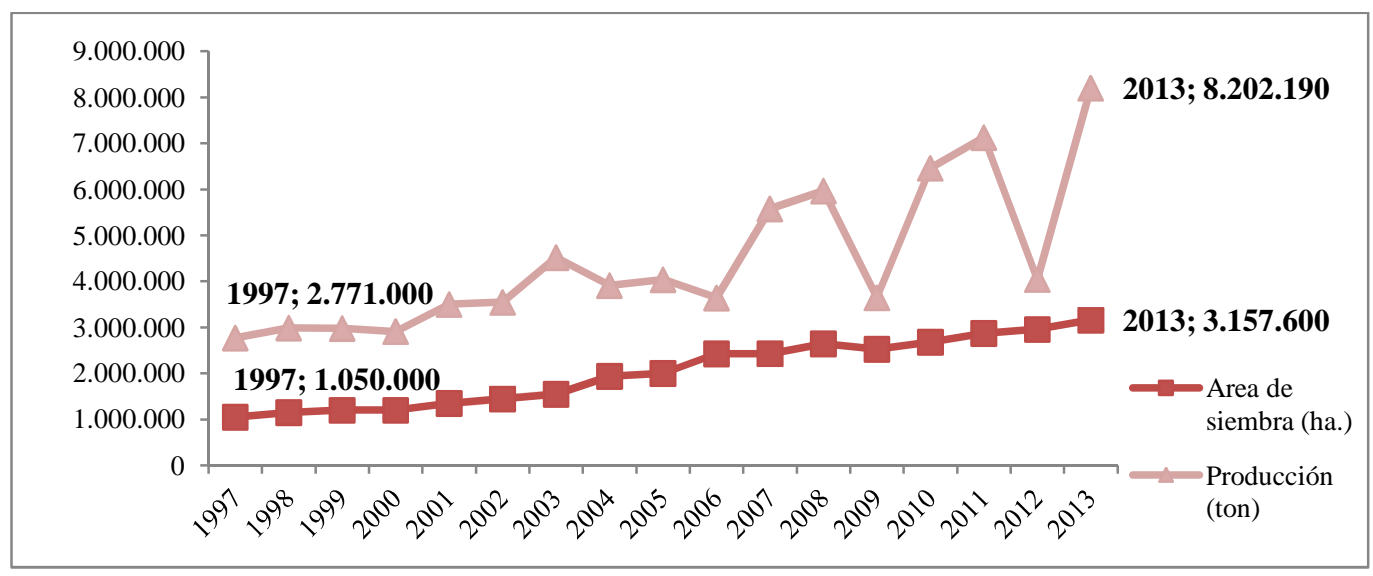

Fonte: Elaboração própria a partir de dados da CAPECO (2014)

As exportações de soja também têm aumentando constantemente, acompanhando o ritmo de crescimento na produção. Nesse contexto, tem havido uma maior inclinação para a exportação da soja em estado bruto, conforme evidencia a composição das exportações totais do país. De acordo com a CAPECO (2014), ao longo das duas últimas décadas, em média, 71\% da produção total de soja foi diretamente para a exportação, ao passo que, apenas $26 \%$ da produção foi industrializada ${ }^{143}$. Conforme apontado na seção anterior, recentemente tem havido maiores esforços no sentido de aumentar a capacidade

${ }^{143}$ Conferir Tabela 15, sobre o uso da soja no Paraguai, em anexo. 
de processamento, principalmente, por parte das corporações transnacionais. Com efeito, em 2013 - ano em que se inauguraram diversas obras para tais fins - 37\% da soja produzida foi industrializada, dobrando o volume de anos anteriores.

Outro indicativo do avanço da agricultura empresarial é a consolidação das grandes unidades agrícolas, na medida em que as inovações técnicas e tecnológicas (que também definem os padrões de competitividade no setor) para a produção das commodities só conseguem ser acessíveis (e rentáveis) para as unidades que as produzem em grande escala. Com efeito, no caso da soja, $87 \%$ do total da superfície cultivada em 2008 corresponderam a lotes (propriedades) acima de 100 hectares (MAG, 2008).

Nessa mesma linha, a expansão do modelo do agronegócio também resulta em tendências, cada vez mais acirradas, de concentração na propriedade da terra uma vez que, as pequenas unidades e empresas familiares vão perdendo peso na estrutura, com o avanço das grandes unidades agropecuárias. A esse repeito, o Censo Agropecuário Nacional de 2008 apontou que, no Paraguai, 2,58\% do total de propriedades abarcavam $85,48 \%$ das terras, enquanto $97,41 \%$ das propriedades restantes possuíam apenas $14,52 \%(\mathrm{MAG}, 2008)^{144}$.

Com relação à participação do capital estrangeiro na estrutura da propriedade da terra no país, o CAN de 2008 apontou números que, a princípio, parecem pouco significativos: dos 278.967 proprietários individuais registrados, apenas $11.787(4,2 \%)$ são de nacionalidade estrangeira. O censo, entretanto, além de não fornecer informações sobre a origem nacional de outros tipos de proprietários - como as unidades com mais de um proprietário ou as sociedades (empresas) - também não revelou a distribuição das nacionalidades em termos de superfície ocupada. Nesse contexto, muitos analistas têm se esforçado para oferecer estimativas com relação à quantidade de hectares que estaria sob propriedade estrangeira.

Em um estudo sobre o fenômeno da "estrangeirização" no Paraguai, Glauser (2009:35), utilizando dados do censo de 2008, estimou que pelo menos 7,7 milhões de hectares (aproximadamente, 19,4\% do território nacional) seriam propriedade de estrangeiros - sendo que, desses 7,7 milhões de hectares, em torno de 4,7 milhões (62\%), estariam em mãos de proprietários brasileiros.

\footnotetext{
${ }^{144} \mathrm{O}$ índice Gini (de desigualdade) calculado para o campo em 2008 foi 0,93\%, representando um aumento com relação ao censo anterior de 1991, onde esse índice foi de 0,91 (MAG, 2008).
} 
Partindo dos mesmos dados fornecidos pelo censo de 2008, Galeano (2012a, b) também traçou importantes considerações a respeito do fenômeno da estrangeirização. Realizando uma análise por estratos de propriedade, Galeano (2012b:413) assinalou que, dentre os proprietários com lotes acima de 1000 hectares - tamanho característico dos grandes empreendimentos ${ }^{145}$ - a parcela de proprietários estrangeiros aumentou entre 1991 e 2008, passando de $14 \%$ em 1991, para 24\% em 2008, entre os quais se destacam os proprietários de origem brasileira, com uma participação de $14,2 \%$ do total. Por sua vez, essa parcela varia em função da região do país em foco, sendo mais significativa nos departamentos que fazem fronteira com o Brasil. Por exemplo, em Canindeyú, a parcela de proprietários brasileiros com lotes acima de 1000 hectares é de 60,1\%; em Alto Paraná é de 55,2\%; e em Amambay é de 34,8\% (ver Figura 11 e Tabela 13).

\section{Figura 11 - Mapa dos departamentos com maior número de proprietários estrangeiros (nos lotes acima de 1mil hectares) - 2008}

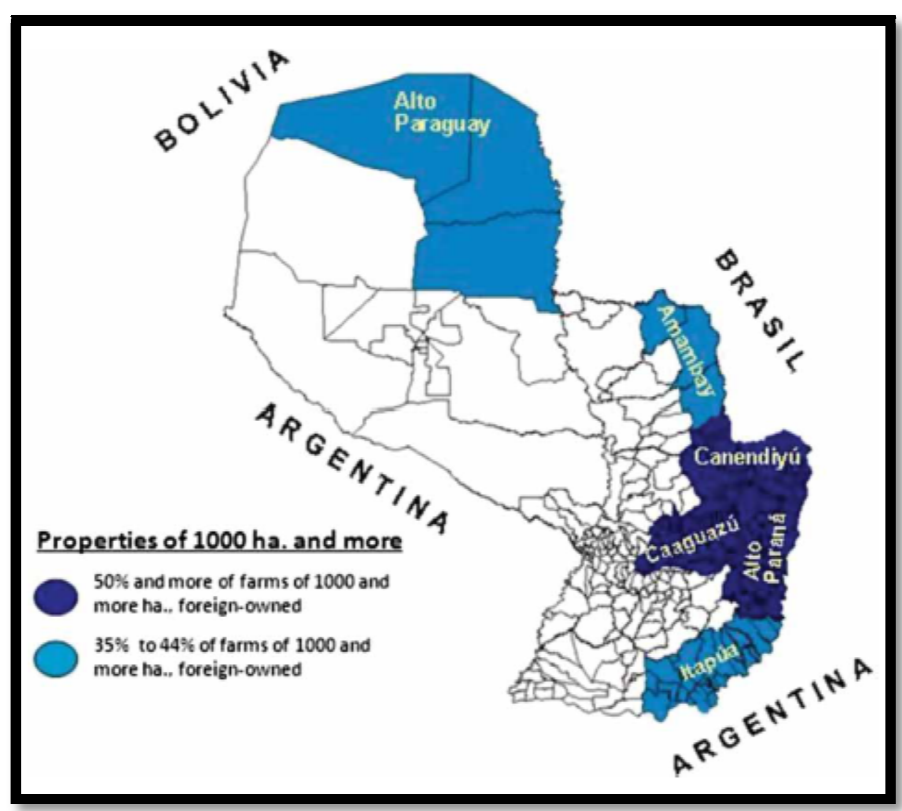

Fonte: Galeano (2012a:460)

145 É importante notar que, embora esse estrato represente apenas $1,6 \%$ do total dos lotes registrados no país, ele ocupa $79 \%$ do total das terras (MAG, 2008), evidenciando as fortes tendências de concentração, e a centralidade que essas grandes unidades ocupam em tal dinâmica. 
Tabela 13 - Distribuição percentual de proprietários individuais de acordo com a nacionalidade por departamento - Lotes acima de mil ha. - Ano de 2008

\begin{tabular}{|l|c|c|c|}
\hline $\begin{array}{c}\text { Departamentos } \\
\text { (estados) }\end{array}$ & Paraguaios & Brasileiros & $\begin{array}{c}\text { Outras } \\
\text { nacionalidades }\end{array}$ \\
\hline Todo o país & 76,5 & 14,2 & 9,3 \\
\hline Concepción & 77,5 & 16,7 & 5,8 \\
\hline San Pedro & 89,6 & 2,6 & 7,8 \\
\hline Cordillera & 100 & $\ldots$ & $\ldots$ \\
\hline Guairá & 88,9 & 5,6 & 5,5 \\
\hline Caaguazú & 38,1 & 32,1 & 29,8 \\
\hline Caazapá & 76,8 & 14,3 & 8,9 \\
\hline Itapúa & 56,3 & 20,7 & 23 \\
\hline Misiones & 94,9 & 2,6 & 2,5 \\
\hline Paraguari & 92,9 & 1,2 & 5,9 \\
\hline Alto Paraná & 37,5 & 55,2 & 7,3 \\
\hline Central & 87,5 & $\ldots$ & 12,5 \\
\hline Ñeembucú & 99,2 & $\ldots$ & 0,8 \\
\hline Amambay & 59 & 34,8 & 6,2 \\
\hline Canindeyú & 37,4 & 60,1 & 2,5 \\
\hline Presidente Hayes & 96 & 0,4 & 3,6 \\
\hline Alto Paraguay & 65,9 & 22 & 12,1 \\
\hline Boquerón & 83,9 & 0,2 & 15,9 \\
\hline
\end{tabular}

Considerando que as grandes unidades agrícolas são as que se especializam mais intensamente na produção dos cultivos comerciais (commodities), pode-se esperar que os produtores e empresários estrangeiros também tenham uma participação significativa nessa dinâmica. De fato, Galeano (2012b) apontou que dos 2.463.510 hectares de soja cultivados em 2008, 64\% correspondia a produtores estrangeiros. O autor também destacou o predomínio dos brasileiros na produção desse cultivo, que chegam a representar $50 \%$ de todos os produtores de soja no país (ver Figura 12). 
Figura 12 - Quantidade de hectares (em \%) cultivados de soja por nacionalidade de produtores e tamanho das propriedades - Ano 2008

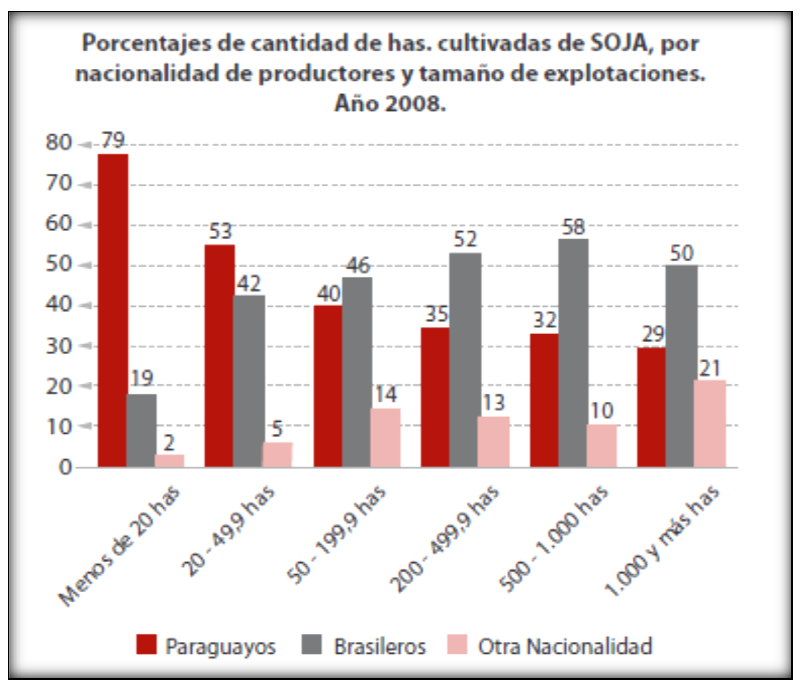

Fonte: Galeano (2012b:414)

A partir dessas observações, Galeano (2012a, b) concluiu que, a participação estrangeira na estrutura da propriedade agrícola no Paraguai ressalta no grupo das grandes propriedades (lotes). Da mesma forma, considerando que essas unidades agrárias maiores são as que realizam grande parte da produção agrícola empresarial, o autor constatou que os produtores e empresários estrangeiros, de fato, têm uma participação importante nessa dinâmica (como se verificou no caso da soja).

Nesse sentido, Galeano (2012b) argumenta que existe uma forte correlação positiva entre as tendências de concentração da terra (tanto em termos de uso e de propriedade) e o fenômeno da "estrangeirização". Em outras palavras, constata-se que os capitais e empresários estrangeiros (especialmente, de origem brasileira) são os principais impulsionadores do crescimento da produção de soja (e de outras commodities agropecuárias) ${ }^{146}$ e da consolidação das grandes unidades agrícolas isto é, são os principais agentes por trás do contínuo avanço da agricultura empresarial no país.

\footnotetext{
${ }^{146}$ Além da soja, Galeano (2012b) também identificou tal correlação na dinâmica de produção de outros bens agrícolas associados ao agronegócio, porém, em graus menores. É o caso da atividade pecuária que, nos últimos anos, tem ganhado centralidade como impulsionador do processo de concentração e estrangeirização da terra no país, em função da dinamização da indústria da carne no país e na região. Nesse âmbito, as grandes unidades produtivas do país - isto é, as que contam com o maior número de cabeças de animais - ainda pertencem, predominantemente, a empresários e produtores paraguaios. Contudo, ao considerarem-se os estratos maiores, a presença de estrangeiros se acentua, confirmando a correlação anteriormente descrita. Por outro lado, também se constata o predomínio dos empresários e produtores de origem brasileira (Galeano, 2012b).
} 
Por fim, um aspecto relevante a respeito do processo atual de concentração e estrangeirização da terra no país, referem-se aos novos processos de expansão da fronteira agrícola que, no caso da região Oriental, avança para além da tradicional região fronteiriça, em direção a áreas mais centrais, e que no caso da região Ocidental (Chaco), avança rapidamente nas áreas de fronteira com o Brasil (Souchaud, 2007; Glauser, 2009; Campos, 2013).

No caso do Chaco, o processo tem-se acelerado, especialmente, no departamento de Alto Paraguay, onde Galeano (2012b) verificou que a parcela de proprietários estrangeiros no estrato acima de 1000 ha. passou de 6\% em 1991 para 34\% em 2008. O aumento da estrangeirização nessa área está intimamente relacionado ao crescimento na instalação de unidades de produção pecuária - que prescindem de grandes extensões de terra para suas operações - e aos preços (muito menores) das terras nessa região.

Esses novos movimentos se refletem nos registros de compra de terras por empresas estrangeiras nos últimos anos. De fato, tais operações têm sido maiores na região Ocidental (Chaco) e, sobretudo, no departamento do Alto Paraguay (ver Tabela 14). Por sua parte, os departamentos localizados ao leste da região oriental, que fazem fronteira com o Brasil - especialmente, Alto Paraná e Canindeyú - continuam mantendo uma forte preferência dos investidores. Já o incipiente deslocamento para áreas mais centrais do país se constata pela prioridade que o departamento de Caaguazú, e em menor medida o de San Pedro, têm adquirido nas compras de terras por estrangeiros (Galeano, 2012b) ${ }^{147}$.

Nessas dinâmicas verifica-se, novamente, que os brasileiros se colocam como os principais compradores de terras no Paraguai - isto é, constituem um dos principais impulsionadores da dinâmica atual de estrangeirização no país. Por outro lado, Galeano (2012b:418) apontou que também há um número significativo de proprietários brasileiros entre os vendedores de terras: trata-se dos pequenos e médios produtores que migraram em décadas anteriores, e que estão atualmente vendendo suas terras para grandes empresas - o que evidencia a contínua

\footnotetext{
${ }^{147}$ Para a obtenção das informações apresentadas na Tabela 14, o autor recorreu a publicações em jornais e a informantes qualificados (empresários, técnicos agropecuários, e promotores de ONGs). Isso deixa em evidência a escassez de dados oficiais e a consequente dificuldade em definir melhor as dinâmicas atuais da estrangeirização. Por outro lado, determinar os volumes de terra adquiridos nos últimos anos e as nacionalidades dos compradores constitui uma tarefa complexa, na medida em que existe uma diversidade de atores envolvidos, com diferentes níveis de mediação, assim como diferentes formas de acesso à terra (como o arrendamento ou contrato).
} 
consolidação da grande empresa agrícola, independentemente, da origem nacional dos ocupantes da terra.

Tabela 14 - Terras compradas por empresários estrangeiros (acima de 1000 ha.) nas regiões de "estrangeirização intensiva" (2006-2010)

\begin{tabular}{|l|r|r|l|}
\hline Departamentos & $\begin{array}{c}\text { Hectares } \\
\text { comprados } \\
\text { entre 2006- } \\
\mathbf{2 0 1 0}\end{array}$ & $\begin{array}{c}\text { Total de } \\
\text { hectares } \\
\text { comprados } \\
\text { até 2010 }\end{array}$ & Nacionalidade dos principais compradores \\
\hline Concepción & 70.000 & 250.000 & 1. Brasileiros; 2. Franceses; 3. Alemães \\
\hline San Pedro & 130.000 & 325.000 & 1. Brasileiros; 2. Alemães; 3. Portugueses \\
\hline Caaguazú & 180.000 & 370.000 & $\begin{array}{l}\text { 1. Brasileiros; 2. Alemães; 3. Japoneses; } 4 . \\
\text { Espanhóis }\end{array}$ \\
\hline Caazapá & 50.000 & 180.000 & 1. Alemães; 2. Portugueses; 3. Brasileiros \\
\hline Itapúa & 100.000 & 400.000 & $\begin{array}{l}\text { 1. Brasileiros; 2. Alemães; 3. Japoneses; } 4 . \\
\text { Espanhóis }\end{array}$ \\
\hline Alto Paraná & 150.000 & $\mathbf{7 0 0 . 0 0 0}$ & 1. Brasileiros; 2. Argentinos; 3. Portugueses \\
\hline Amambay & 80.000 & 450.000 & 1. Brasileiros; 2. Portugueses \\
\hline Canindeyú & 170.000 & 650.000 & 1. Brasileiros; 2. Alemães \\
\hline Alto Paraguay & 900.000 & $\mathbf{2 . 5 0 0 . 0 0 0}$ & 1. Brasileiros; 2. Uruguaios; 3. Estadunidenses \\
\hline Total & 1.830 .000 & 5.825 .000 & \multicolumn{2}{|l|}{} \\
\hline \multicolumn{3}{|r|}{} & Fonte: Galeano (2012b:418) \\
\hline
\end{tabular}

\section{3}

\section{A expansão do agronegócio e da presença brasileira no Paraguai: dinâmicas de alianças e conflitos}

O avanço do agronegócio no Paraguai é possível graças ao constante apoio do governo paraguaio - responsável pela adoção de políticas favoráveis ao fortalecimento desse modelo de desenvolvimento - e à forte convergência de interesses que existe entre os grupos empresariais envolvidos nas atividades (tanto locais como estrangeiros). Por outro lado, a expansão da agricultura empresarial no país e o aprofundamento da integração com os mercados mundiais não têm sido livre de conflitos, na medida em que esses processos têm contribuído para o aumento da concentração de riqueza na população - especialmente da terra - e para a consequente exclusão social no país.

A presente seção tem por objetivo explorar, brevemente, essas dinâmicas de alinhamento e conflitos entre os diferentes atores envolvidos (ou marginalizados) na atividade, por meio da análise de alguns eventos polêmicos e questões controversas que evidenciam essas dinâmicas - como a questão da política tributária para a atividade agroexportadora; a forma de atuação dos principais grêmios empresariais do setor; e os conflitos recentes em torno da 
problemática do acesso à terra. $\mathrm{Na}$ análise, procura-se ressaltar o papel dos empresários e produtores brasileiros que, conforme visto anteriormente, têm um peso importante na estrutura produtiva, constituindo um elemento peculiar na configuração do agronegócio no Paraguai - que contribui para incrementar a complexidade das dinâmicas sociopolíticas referentes à organização econômica da agricultura no país.

A atuação do Estado paraguaio tem sido central para a constituição de um ambiente propício aos negócios agrícolas, por meio da promoção de políticas de incentivo ao investimento estrangeiro direto, de liberalização do comércio, e de manutenção de uma baixa pressão tributária sobre o setor. Nesse conjunto de medidas, a política de tributos para a atividade agroexportadora tem sido um dos principais incentivos para a expansão do setor. A exportação de grãos em estado bruto, por exemplo, é livre de imposto, o que explica o grande volume de bens agrícolas que são exportados sem processamento. Já, as arrecadações em termos dos impostos de renda e imobiliário do setor agropecuário representam cifras irrisórias, por conta das baixas taxas aplicadas pelo governo ${ }^{148}$.

Assim, tem-se que o setor que mais gera rentabilidade no país é o menos tributado, fato que provoca frequentes questionamentos, advindos de outros setores da população. De fato, diversas vezes tentou-se avançar reformas que aumentassem as taxas aplicadas ao setor, ou que começassem a gravar as exportações de grãos em estado bruto, perante a necessidade de aumentar a capacidade de arrecadação do Estado. Nesse contexto, os grêmios de empresários e produtores têm se manifestado com força para evitar que tais medidas sejam aprovadas, conseguindo, na maioria das vezes, a manutenção de seus benefícios (e, por conseguinte, a alta lucratividade de suas atividades).

Neste ponto, cabe destacar a composição e atuação de alguns desses grêmios, na medida em que adquirem um forte peso na dinâmica política do país. Entre as associações mais antigas, tem-se a "Associação Rural do Paraguai" (ARP), que reúne os produtores agropecuários, especialmente, de criação de gado. De fundação mais recente, em 2005, tem-se a "Unión de Gremios de la

\footnotetext{
${ }^{148}$ De acordo com Rojas (2013:40) a contribuição do setor em termos do imposto de renda tem representado, nos últimos anos, somente $0,2 \%$ do total arrecadado pelo Ministério da Fazenda. Já o imposto imobiliário é de apenas $1 \%$, taxa que é calculada encima do valor fiscal da terra, isto é, de um valor fixado pelo Ministério da Fazenda anualmente, e não sobre o seu valor de mercado (que chega a ser quase cem vezes maior). Dessa forma, esses impostos acabam sendo um estímulo para a concentração da riqueza - e, especialmente da terra.
} 
Producción" (UGP) ${ }^{149}$, que constitui uma associação de diversos grêmios representantes da atividade rural, agroindustrial e agroexportadora, colocando-se, assim, como uma das associações mais relevantes em nível político atualmente. Entre seus sócios figuram os principais representantes do agronegócio da soja, como a CAPECO, a Associação dos Produtores de Soja (APS) e a Federação de Cooperativas da Produção (FECOPROD). Todas as organizações mencionadas assumem um papel importante nas negociações econômicas (nacionais ou internacionais) concernentes ao setor.

Analisando mais detalhadamente a composição desses grêmios, nota-se que também constituem um meio importante para a integração dos empresários estrangeiros - em especial, dos empresários e produtores brasileiros e brasiguaios - na dinâmica política-empresarial do país. Um exemplo disso é a CAPECO que, em sua lista de associadas, além de empresas nacionais, abriga a firmas transnacionais e estrangeiras do agronegócio, entre as quais figuram diversas empresas brasileiras e "brasiguaias" - como a LAR, a Agrotec, a Agrofértil, as empresas do Grupo Favero, entre outras ${ }^{150}$. Também, cita-se o caso de algumas das principais cooperativas de produção que, conforme visto na seção 5.2.1, se formaram com a participação ativa de migrantes brasileiros.

Outro grêmio de formação recente que merece destaque é a CAPPRO, formada em 2006. A CAPPRO é integrada, basicamente, por firmas transnacionais, fato que parece denotar a necessidade dessas empresas de se diferenciarem dos demais grupos, por conta de seus interesses específicos ${ }^{151}$. As

\footnotetext{
${ }^{149}$ O principal objetivo da entidade é o fortalecimento da participação política de seus associados, defendendo seus interesses comuns. Os grêmios associados são: "Asociación de Productores de Semillas del Paraguay" - APROSEMP; (2) "Asociación de Productores de Soja, Cereales y Oleaginosas del Paraguay" - APS; (3) "Asociación Rural del Paraguay" - ARP; (4) "Cámara de Fitosanitarios y Fertilizantes" - CAFYF; (5) "Coordinadora Agrícola del Paraguay" - CAP; (6) "Cámara Paraguaya de Sanidad Agropecuária" - CAPASAGRO; (7) "Cámara Paraguaya de la Stevia" - CAPASTE; (8) "Cámara Paraguaya de Exportadores de Cereales y Oleaginosas" CAPECO; (9) "Cámara Paraguaya de la Carne" - CPC; (10) "Federación de Cooperativas de Producción” - FECOPROD; (11) "Federación Paraguaya de Madereros" - FEPAMA; (12) "Sociedad Nacional de Agricultura” - S.N.A; (13) “Centro Azucarero Paraguayo” - CAP; (14) "Cámara Paraguaya de Exportadores de Sésamo" - CAPEXSE (UGP, 2014).

${ }^{150}$ Dentre as empresas transnacionais e estrangeiras presentes no país, algumas das que integram o grêmio são: Syngenta, ContiParaguay, Noble, Nidera, CHS, e Vicentin (CAPECO, 2014).

${ }^{151}$ Das onze empresas integrantes do grêmio, seis são representantes diretas de transnacionais do agronegócio com atuação global: ADM Paraguay; Bunge Paraguay; Cargill; ContiParaguay; Louis Dreyfus Commodities (LDC); e Noble Paraguay. As demais empresas associadas são: Aceites y Derivados S.A. (ADESA); Alberto Giles Agroexportadora S.A. (ALGISA); Fábrica de Aceites Vegetales BISA; Compañía Paraguaya de Granos (COPAGRA); e Oleaginosa RAATZ S.A. (CAPPRO, 2014).
} 
integrantes da CAPPRO, de fato, se distinguem por serem as principais firmas agroexportadoras do país $\mathrm{e}$ as empresas que mais tem investido na industrialização dos grãos e cereais, levando-as a assumir um posto de destaque na estrutura do agronegócio no país.

O forte oligopólio exercido pelas empresas transnacionais ao longo da cadeia agroexportadora tem sido contestado por outros grupos empresariais do setor, seja exigindo que essas firmas cumpram estritamente com as leis e com os contratos assinados com os produtores ${ }^{152}$, seja realizando esforços para encontrar alternativas a esse oligopólio - por exemplo, buscando outros canais para as exportações de grãos, inclusive, procurando o apoio de seus pares no Brasil para tais fins ${ }^{153}$.

Em termos de polêmicas e conflitos, contudo, os mais acirrados são aqueles em que acontece o confronto entre os promotores do modelo (produtores e empresários do agronegócio) e os marginalizados do mesmo (pequenos agricultores e os campesinos sem terra). Nessas situações, a aliança entre os grupos empresariais se torna mais clara. Por sua parte, o Estado, geralmente acaba agindo em favor dos primeiros - seja por ações concretas ou por omissão, evidenciando, na maioria das ocasiões, a sua profunda fraqueza institucional.

Os grupos diretamente prejudicados pelo avanço da agricultura empresarial, e a população em geral, têm motivos válidos para contestar e manifestar sua insatisfação com os resultados do agronegócio, pois, apesar do

\footnotetext{
${ }^{152}$ A esse respeito ressaltam-se dois episódios. O primeiro, referente ao pagamento de um tributo no Paraguai - o Imposto sobre o Valor Agregado (IVA). Embora o tributo esteja generalizado para o setor, as transnacionais parecem estar empurrando a sua parcela do pagamento para os produtores. Recentemente, isso gerou reações por parte dos produtores e seus representantes, que se veem prejudicados, na medida em que, além de tentar se livrar da sua parcela do IVA, as transnacionais são as que conseguem usufruir dos benefícios da política de "devolução de 50\% do IVA", aplicada quando os produtos taxados por esse imposto são exportados (operação realizada, maiormente, por essas empresas). O segundo caso, refere-se à polêmica gerada em finais de 2012, quando a APS patrocinou uma iniciativa para suspender o pagamento de royalties à multinacional Monsanto, pela tecnologia utilizada no cultivo, em vista de que a patente dos produtos já estaria vencida. A iniciativa encontrou motivação em um empreendimento similar no Brasil, realizada por uma associação de produtores do estado de Mato Grosso que, no caso, obteve uma resolução favorável. A respeito do primeiro caso, ver: "Productores piden a multinacionales que respetem la ley y paguen el IVA”, notícia do jornal Última Hora, de 27 de abril de 2014 (Última Hora, 2014b). A respeito do segundo caso, ver: "Productores paraguayos de soja se niegan a pagar regalías a Monsanto", notícia do jornal Reuters América Latina, de 25 de outubro de 2012 (Reuters, 2012).

153 "Cinco multinacionales, ADM, Bunge, Cargill, Dreyfus y Noble, manejan el 80\% de las exportaciones de soja que se produce en Paraguay; y ante dicho oligopolio, la Cámara Paraguaya de Exportadores de Cereales y Oleaginosas (Capeco) se propone con la Aprosoja, de Brasil, crear un canal alternativo para los envíos, con las cooperativas" - notícia do jornal ABC Color de 25 de julho de 2013 (ABC Color, 2013a).
} 
forte crescimento que essas atividades têm gerado para a economia do país (em termos de PIB), o avanço da agricultura empresarial não tem se refletido em um melhoramento das condições de vida da maioria da população.

De acordo com Borda (2011:112), enquanto a economia cresceu 42\% entre 1997 e 2010, o nível de pobreza não tem se modificado, variando em torno de $35 \%$ a $40 \%$ da população - sendo que esses índices são maiores no campo, mantendo-se em torno de $50 \%$ do total da população rural, nesse mesmo período. Esse contraste é ainda mais forte quando se considera, especificamente, o crescimento do setor agrícola. Segundo Borda (2011), enquanto o subsetor da agricultura apresentou as maiores taxas de crescimento nas últimas duas décadas $3,6 \%$ entre 1989 e 2002, e 8,7\% entre 2003 e 2010 - a população ocupada na agricultura passou de 35,8\% em 1992, para apenas 26,8\% em 2010. Ao mesmo tempo, tem-se o paradoxo que, a despeito do crescimento na produção agropecuária, o país tem uma das populações mais precariamente nutridas da região, com aproximadamente $25 \%$ (em trono de 1,6 milhão de pessoas) passando fome no país ${ }^{154}$.

Esses resultados estão relacionados à lógica da agricultura empresarial que, conforme mencionado anteriormente, favorece a produção intensiva em capital e em grande escala, de tal forma que, ao se expandir, concentra cada vez mais superfícies de terra (e outros recursos), deslocando outras unidades ou modos de produção menos "competitivos", além de provocar a diminuição das possibilidades de emprego no campo. Dessa forma, verifica-se uma constante redução da participação do pequeno produtor e dos campesinos na economia agroexportadora, em detrimento da grande empresa agrícola (Galeano, 2012b, $2011 b)^{155}$. Certamente, a repercussão negativa que o crescimento do agronegócio tem gerado - especialmente, em termos de seus resultados sociais - também está estreitamente relacionada à questão da baixa pressão tributária aplicada ao setor e

\footnotetext{
${ }^{154}$ A esse respeito, ver: "FAO recordó que 1.600 .000 personas sufren hambre em Paraguay", notícia do jornal digital E'a, de 17 de outubro de 2012 (E'A, 2012); e "ONU: Paraguay es el país peor alimentado de Sudamérica", notícia do jornal Infobae América, de 22 de maio de 2013 (INFOBAE, 2013).

${ }^{155}$ Concomitantemente a esse processo, Borda (2011) aponta para a crescente urbanização do país, que se alimenta, sobretudo, pela migração campo-cidade, em função da ausência, cada vez maior, de oportunidades de emprego no campo. No período entre 1992 e 2010, embora continue representando um número alto, a população rural no Paraguai diminuiu significativamente, passando de $49,7 \%$ para $41 \%$ do total da população. Para o autor, uma das principais implicações da crescente urbanização tem sido o aumento da informalidade e precariedade laboral, denotada por uma taxa de subemprego de $22,9 \%$ (em 2010).
} 
ao caráter regressivo desses impostos, que impedem uma distribuição mais equitativa dos ganhos obtidos com a atividade.

Dentro desse contexto de reprodução da pobreza e da desigualdade social, as questões envolvendo a distribuição da terra constituem um dos aspectos mais graves, dado o alto grau de concentração existente - tanto em relação ao uso (para o cultivo de commodities) quanto em relação à propriedade (poucas unidades concentrando grandes superfícies de terra), conforme visto na seção 5.2.2 - e a frequência com que emergem conflitos em torno dessa situação.

A problemática da terra no país se complica, atualmente, em função de dois aspectos: primeiro, pelo fato que, muitas das terras possuídas pelos grandes proprietários atuais, foram adquiridas em condições irregulares - principalmente, durante o governo de Stroessner (1954-1989), época em que os processos de colonização e adjudicação de terras foram marcados por inúmeros desvios e casos de corrupção ${ }^{156}$; e segundo, em função de que, muitas das terras que serviriam para a formação de novas colônias e assentamentos de produtores paraguaios (no contexto do projeto de colonização dos anos 1960-1970), acabaram sendo adquiridas por colonos e empresários brasileiros ${ }^{157}$.

Por outro lado, é preciso apontar que, no período democrático (pós 1989), as irregularidades nos processos de adjudicação e titulação de terras continuam acontecendo. Fogel (2013:20) aponta a existência de pelo menos cinco tipos de irregularidades na apropriação de terras: as terras "mal habidas", adjudicadas no período da ditadura, que permanecem sem ser regularizadas; as terras adjudicadas erroneamente, isto é, as que passam a ser propriedade de sujeitos não beneficiários da reforma agrária, ou que se referem à má administração das colônias já estabelecidas; as terras "adicionais", incorporadas por "via de fato", isto é, de propriedades previamente registradas que se expandem para áreas vizinhas desocupadas; e finalmente, terras com títulos diretamente falsificados (ou adulterados de outras formas).

\footnotetext{
${ }^{156}$ De acordo com o relatório final da Comissão de Verdade e Justiça - publicado em 2008 - que investigou as condições em que foram realizadas as adjudicações de propriedades rurais por parte dos organismos estatais (entre 1954 e 2003), do total de hectares distribuídos nesse tempo - que representam em torno de 50\% das terras cultiváveis do país $-32,7 \%$ foram atribuídas com graves irregularidades. Essas terras de propriedade ilegítima - comumente denominadas como terras " $m a l$ habidas" - por sua vez, representariam perto de 19,3\% do território nacional (Glauser, 2009:32).

${ }^{157}$ É por isso que, os proprietários brasileiros e seus descendentes aparecem, frequentemente, na linha de frente dos conflitos agrários contemporâneos. Nesse cenário, as reivindicações pelo acesso à terra também ganham a conotação de uma reivindicação pela soberania do país.
} 
Em linhas gerais, o que se tem hoje como resultado do processo histórico recente é que muitas das terras que deveriam ser utilizadas na reforma agrária não estão cumprindo a função para o qual foram destinadas, na medida em que muitos dos destinatários originais não estão sendo beneficiados. Até hoje, não existe, nem se conseguiu realizar, um cadastro imobiliário único e atualizado das propriedades rurais do país, um elemento que seria central para a determinação do número de lotes e proprietários (títulos) existentes, e para o saneamento das irregularidades o que evidencia a fraqueza institucional (ou a falta de vontade política) das entidades estatais ${ }^{158}$.

A instituição responsável atualmente pelas atividades da reforma agrária é o INDERT ${ }^{159}$. Desde sua constituição (em 2002), a entidade já avançou diversas iniciativas no sentido de regularizar a situação das terras no país, mas todas têm sido truncadas, especialmente, a partir da mobilização dos grandes produtores rurais e de suas representações de grêmio - que também contam com o respaldo de agentes governamentais e do sistema judiciário.

Outro exemplo de iniciativa, no sentido de amenizar a problemática da terra - em especial, do fenômeno da "estrangeirização" - que ganhou ampla resistência dos setores empresariais, foi a promulgação da Lei de Segurança Fronteiriça (Lei 2.532/5). Essa medida estabeleceu uma faixa de $50 \mathrm{~km}$. adjacente às linhas de fronteira, como área de segurança estratégica, proibindo nessas áreas a venda de terras a estrangeiros oriundos dos países limítrofes com o Paraguai ${ }^{160}$. Para a realização das tarefas de demarcação da faixa e de cadastramento das propriedades existentes na mesma, criou-se a "Comisión Interinstitucional para la Zona de Seguridad Fronteriza (CIZOSEF)", que começou os primeiros trabalhos em 2007. Porém, na medida em que as tarefas foram avançando - principalmente, durante o governo de Fernando Lugo (2008-2012), quando a lei ganhou regulamentação oficial - a iniciativa passou a encontrar resistências ${ }^{161}$.

\footnotetext{
${ }^{158}$ Um dos problemas mais comuns em relação à situação caótica dos registros de propriedade é a superposição de títulos. De acordo com Rojas (2014), o somatório das superfícies dos títulos existentes supera os 500 mil km², em um país cuja superfície oficial é de $400 \mathrm{mil} \mathrm{km²}$.

${ }^{159}$ O "Instituto Nacional de Desarrollo Rural y de la Tierra (INDERT)" que, em 2002, substituiu ao antigo IBR, passando a ser o responsável pela aplicação da Lei que estabelece o Estatuto Agrário e, por conseguinte, pela administração das terras públicas destinadas à reforma agrária.

${ }_{160}$ O Estatuto Agrário de 1940 já proibia que estrangeiros comprassem terras nas regiões fronteiriças, mas essa cláusula havia sido revogada em 1963, no contexto do projeto de colonização agrícola da região fronteiriça, durante o governo de Stroessner (Glauser, 2009).

${ }^{161}$ As resistências emanaram, fundamentalmente, dos produtores e proprietários rurais instalados nas regiões de fronteira, que se sentiam ameaçados de perder suas parcelas, e passaram a agir no
} 
Em anos recentes, as agitações relacionadas à problemática da terra ganharam dinamismo, especialmente, durante o governo de Fernando Lugo ${ }^{162}$, contexto em que o INDERT tentou avançar mais firmemente nos trabalhos de regularização das terras. Isto ocasionou reações de vários setores: por um lado, dos campesinos sem terra, que apoiavam os trabalhos da entidade e ao longo desse período realizaram uma oleada de ocupações de terras - como medida de força para o avanço dos trabalhos do INDERT, e para o atendimento de suas reivindicações; e por outro, dos grandes produtores e grêmios empresariais do agronegócio, que rejeitavam tanto as ações do INDERT, como as ocupações, na medida em que provocavam instabilidade e insegurança para seus negócios.

Nesse contexto, se desdobraram dois casos que ganharam ampla repercussão, e que exemplificam as dinâmicas que se buscam evidenciar nesta seção:

(1) O caso de Nacunday - distrito localizado na região leste do departamento do Alto Paraná (na fronteira com o Brasil) - que envolveu o grupo dos campesinos sem terra e o empresário brasiguaio Tranquilo Favero. Em abril de 2011, campesinos sem terra (em torno de 400 famílias) começaram a ocupação de parte de uma fazenda pertencente ao Grupo Favero, na expectativa de recuperação de 2 mil hectares de terras públicas que estariam indevidamente ocupadas pela empresa $^{163}$. Atendendo à denuncia, o INDERT realizou os primeiros trabalhos de verificação no território, constatando a existência de títulos superpostos, e por tanto, de irregularidades, levando à necessidade de realização de mais medições no local, a fim de determinar a localização exata das terras usurpadas. A ocupação por parte das famílias campesinas aconteceu em meio desses trabalhos de

sentido de dificultar os trabalhos de medição. Os grêmios empresariais também passaram a repudiar a medida, questionando a real eficácia da lei para lidar com a problemática da terra, dado que o processo (de "estrangeirização") já se encontraria em um estágio avançado, servindo apenas para criar instabilidade e dificultar os processos de integração regional.

${ }^{162}$ A ascensão de Fernando Lugo ao governo (em 2008) marcou um evento histórico no país, uma vez que colocou fim à longa hegemonia do Partido Colorado, que permaneceu 60 anos no poder ao longo do período ditatorial (1954-1989) e inclusive durante a transição democrática. Além disso, Fernando Lugo mostrava ter uma maior inclinação pelas causas dos setores sociais, e especialmente, da questão agrária, diferentemente dos governos anteriores. O mandato de Lugo foi interrompido em junho de 2012 - quase um ano antes das próximas eleições presidenciais - por meio de um processo de impeachment, levado a cabo após o episódio trágico de Curuguaty (conflito envolvendo a questão das terras, a ser tratado adiante).

163 A Comissão De Vizinhos de Santa Lucia - organização que representa às famílias campesinas sem terra desse caso - entrou com o processo de reivindicação dessas terras já em 1999 (Fogel, 2013). 
verificação do INDERT. Ao mesmo tempo, os representantes do setor empresarial - como a APS, ARP e a UGP - passaram a manifestar-se, defendendo o respeito absoluto à propriedade privada e a necessidade de tranquilidade (e não de instabilidade) para a realização de suas atividades. Assim, o setor empresarial solicitava ao governo colocar um fim à onda geral de ocupações, apoiando também a suspensão dos processos de medição do INDERT (contexto no qual se incluía o caso de $\tilde{N}$ acunday $)^{164}$. Finalmente, após diversas detenções de camponeses no local realizadas pela polícia, e na medida em que juízes e fiscais da região conseguiram abortar os trabalhos de medição, as famílias foram sendo desalojadas e realocadas em uma área de reserva adjacente às terras do grupo Favero - o "Parque Nacional de Nacunday" - à espera de uma solução definitiva por parte do governo.

(2) O caso de Curuguaty, que é similar ao de Ñacunday, no sentido de que está associado a um longo processo de reivindicação e recuperação de terras públicas apropriadas indevidamente, envolvendo campesinos sem terra e grandes proprietários (neste caso, a empresa Campos Morombí, do político paraguaio Blas N. Riquelme) $)^{165}$. O caso de Curuguaty ganhou destaque após o trágico desfecho de uma operação de desalojo realizada no local da ocupação a pedido da empresa, que resultou na morte de seis policiais e onze camponeses - sendo também o episódio que serviu de gatilho para levar adiante o processo de destituição (impeachment) do então presidente Fernando Lugo, por parte do Congresso paraguaio (em junho de 2012), iniciativa que recebeu o apoio dos grêmios do agronegócio. O episódio de Curuguaty, e a destituição de Lugo, se colocaram como um freio para as mobilizações dos setores sociais, especialmente, no campo. Por sua parte, os trabalhos do INDERT foram interrompidos, sendo que um ano

\footnotetext{
${ }^{164}$ Uma das manifestações de força dos grandes produtores e empresários do agronegócio, em repúdio aos acontecimentos no campo nesse período, foi a realização do "tractorazo" - que consiste na ocupação da beira das estradas com seus tratores - em julho de 2011, que contou com a participação de produtores paraguaios e brasileiros, e com o apoio de autoridades municipais e dos grêmios da produção (como a CAP, ARP e a UGP). A respeito disso, ver "Tractorazo seguirá por tiempo indefinido", Jornal ABC Color, 14.07.2011, disponível em: http://www.abc.com.py/nacionales/tractorazo-seguira-por-tiempo-indefinido-283085.html. Acesso em 28 de abril de 2014.

${ }^{165}$ Ambos os casos - Nacunday e Curuguaty - são repletos de controvérsias, muitas das quais irresolvidas até hoje, não fazendo parte do escopo do presente trabalho a realização de uma análise profunda sobre esses acontecimentos. Para estudos mais aprofundados sobre esses casos, ver Fogel (2013). Já a respeito do impeachment de Lugo, uma série de análises podem ser encontradas em Carbone e Soler (2012).
} 
depois, em julho de 2013, a instituição desistiu oficialmente (por resolução presidencial) de realizar a medição das terras em Nacunday. Dessa forma, as terras em questão continuarão em condição irregular, enquanto as famílias (em torno de 500) seguem esperando uma solução definitiva para a sua situação ${ }^{166}$. A partir da troca de governo (em junho de 2012), houve também uma rápida reativação de processos administrativos de interesse do setor do agronegócio, para os quais o governo de Lugo havia colocado maior resistência. Em um registro das medidas do novo governo nessa direção, Rojas (2014:36) indica, por exemplo, que apenas quinze dias após a assunção do novo presidente, aprovou-se a utilização da semente de algodão transgênica (Bt MON531) da firma transnacional Monsanto. Posteriormente outras variedades de sementes geneticamente modificadas foram sendo aprovadas, sem a realização dos devidos estudos de impacto ambiental - de fato, as exigências para a aprovação dessas sementes foram flexibilizadas pelo novo governo ${ }^{167}$. Nesse sentido, tem-se que o episódio de Curuguaty, e a troca de governo que se seguiu, resultaram em uma forte "ofensiva do agronegócio" (Rojas, 2014) - compreendendo-se, assim, a decisão dos setores empresariais do agronegócio em apoiar o episódio de impeachment $^{168}$.

Em todos os exemplos apresentados anteriormente - envolvendo reivindicações dos setores sociais e ações do governo, seja para a regularização da situação das terras, ou para a amenização dos efeitos nocivos da expansão do

\footnotetext{
${ }^{166}$ No início de 2014, o governou anunciou a localização de um excedente de terras públicas que seriam utilizadas para assentar essas famílias - no distrito de Itakyry, também no departamento de Alto Paraná. Ironicamente, o governo - por meio do INDERT - está encontrando as habituais dificuldades para a demarcação dos lotes em que serão assentadas as famílias campesinas, como a resistência por parte dos produtores e proprietários locais (paraguaios e estrangeiros), para a realização dos trabalhos de medição do terreno. A respeito disso, ver: "Colonos cierran ruta y evitan que el INDERT ingrese a las tierras de Itakyry", notícia do jornal Última Hora, de 25 de março de 2014 (Última Hora, 2014a); e "Expectativa por translado de Ñacunday", notícia do jornal ABC Color, de 27 de março de 2014 (ABC Color, 2014).

${ }^{167}$ Dessa forma, em menos de seis meses - para finais de outubro de 2012 - já tinha se aprovado a utilização de sementes transgênicas para dois novos cultivos: o algodão e o milho (Rojas, 2014).

${ }^{168}$ Além das travas colocadas pelo governo, que dificultavam a expansão das atividades - como no caso da aprovação das sementes - os grêmios da produção acusavam o presidente Lugo de apoiar diretamente a onda de ocupações das propriedades privadas por parte dos campesinos sem terra, que teriam o objetivo de fomentar o "terror" no campo, apontando-o também como responsável direto pelo desfecho trágico em Curuguaty, justificando assim a sua destituição. A respeito disso, ver: "UGP asegura que amerita juicio político a Lugo", notícia do jornal La Nación, de 15 de junho de 2012 (La Nación, 2012); e "Gremios productivos apoyan a Franco", notícia do jornal ABC Color, de 28 de junho de 2012 (ABC Color, 2012b).
} 
agronegócio - o conflito de interesses entre os diferentes atores envolvidos fica mais nítido, evidenciando-se também a forte aliança existente entre os empresários e grandes produtores do setor, que se manifesta, principalmente, na atuação de suas associações de grêmio - que também são integradas por empresas estrangeiras, sobretudo, por empresários brasileiros e brasiguaios ${ }^{169}$.

Neste ponto, cabe mencionar que, todos esses casos envolvendo a verificação da titularidade das terras ou da condição das colônias no Paraguai, também têm sido acompanhados de perto pelo governo brasileiro principalmente, através de suas representações oficiais no Paraguai - na medida em que afetam a uma grande parte da comunidade de brasileiros (e de seus descendentes) residentes no país - os quais também procuram assistência das representações brasileiras nesses casos. A questão da situação migratória e fundiária dos colonos brasileiros e brasiguaios no Paraguai, de fato, tem estado sempre na agenda do governo brasileiro e das relações bilaterais. Nesse contexto, a oferta de apoio do governo brasileiro para a realização de um cadastro atualizado das propriedades rurais tem sido frequentemente reiterada.

Por outro lado, o governo brasileiro também tem acompanhado a dinâmica do agronegócio paraguaio de outras formas, realizando ações em apoio da expansão dos negócios agrícolas brasileiros no país. Cita-se o exemplo do "Foro Brasil-Paraguai", criado em 2001, por iniciativa da embaixada do Brasil no Paraguai e de um grupo de empresários brasileiros residentes no país. O foro tem por finalidade promover, colaborar e participar com iniciativas comerciais, sociais e culturais de seus associados, defendendo seus interesses, e dando-lhes assessoramento. Outros objetivos são financiar e divulgar publicações relacionadas sobre a gestão econômica, comercial e financeira dos países; organizar e participar de conferências; promover convênios, etc. ${ }^{170}$. Entre seus

\footnotetext{
${ }^{169}$ Por exemplo, a Associação dos Produtores de Soja (APS), após a destituição de Lugo, solicitou ao novo governo a revogação imediata da lei de segurança fronteiriça, argumentando que essa regra colocava em situação de vulnerabilidade a muitos de seus membros (imigrantes brasileiros) que haviam apoiado o impeachment. A esse repeito, ver: "Sojeros piden derogar decreto", notícia do jornal ABC Color, de 17 de julho de 2012 (ABC Color, 2012c).

${ }^{170}$ Ressalta-se, por exemplo, a realização anual do evento "Expo Paraguay-Brasil", cuja $5^{\circ}$ edição foi realizada em 2013. Também se menciona a participação do Foro no evento "Oportunidades de Investimentos no Paraguai", realizado no local da FIESP em 2013, cuja programação se encontra disponível em: http://www.fiesp.com.br/indices-pesquisas-e-publicacoes/apresentacoesoportunidades-de-investimentos-no-paraguai/. Acesso em 29 de março de 2014.
} 
associados, o foro tem a empresas brasileiras instaladas no Paraguai (de diferentes ramos), empresas paraguaias, pessoas físicas e associações de grêmio ${ }^{171}$.

Nesse âmbito, podem mencionar-se, também, as políticas aplicadas desde o Brasil em benefício do crescimento da agroindústria brasileira e de sua expansão para os mercados da região e, especificamente, para o Paraguai, por meio de medidas como o apoio às exportações do setor, ou o apoio aos processos de internacionalização de suas empresas. Conforme apontado no capítulo anterior, o BNDES assume um lugar central na canalização e efetivação dessas políticas ${ }^{172}$.

Em suma, o modelo do agronegócio no Paraguai avança graças a uma notável aliança entre os diferentes grupos empresariais envolvidos nas atividades do setor - empresários e produtores, tanto de origem nacional como estrangeira cristalizada na força política de suas representações de grêmio, e a despeito das polêmicas e contestações que emergem com relação aos resultados sociais negativos provocados pelo modelo. Nesse quadro, os conflitos mais acirrados acontecem a partir do confronto entre os beneficiados pelo modelo (empresários em geral) e os marginalizados ou excluídos (pequenos agricultores e campesinos sem terra), especialmente, em torno da questão do acesso à terra.

Com base nos casos, exemplos e dados apresentados anteriormente, verifica-se que, o papel dos capitais e empresários brasileiros na configuração do agronegócio no Paraguai vai além de seu peso econômico, uma vez que, também participam ativamente das dinâmicas sociopolíticas em torno das atividades do agronegócio no país - conforme se constata na conformação e atuação dos principais grêmios do setor. No âmbito dos conflitos - especificamente, dos que envolvem a reivindicação de terras - os empresários e produtores brasileiros e

${ }^{171}$ Entre as associadas figuram: a Associação de Produtores de Soja (APS); as empresas relacionadas ao agronegócio como Agrofértil e o Grupo Favero; e outras empresas como a Petrobrás, Odebretch; e bancos como o Itaú, Banco do Brasil, Banco Familiar, Banco Atlas, entre outras dezenas de associados. O foro também mantém importantes convênios com a Federação de Indústrias do Estado de Mato Grosso do Sul (FIEMS) e com a União Industrial Paraguaia. Informações disponíveis em: http://www.fbp.org.py/. Acesso em março de 2014.

${ }^{172}$ Com relação às medidas de apoio às exportações, cita-se o programa "BNDES Exim automático", que apoia as exportações brasileiras de produtos de alto valor agregado para a região da América Latina, por meio de parcerias com bancos localizados nesses países. No início de 2014, o Paraguai emergia como primeiro colocado na utilização dessa linha de crédito. No âmbito das medidas de apoio à internacionalização das empresas brasileiras, cita-se o caso da cooperativa LAR S.R.L. que, em 2005, recebeu um financiamento de US\$2,6 milhões por parte do banco para a expansão de suas operações no Paraguai (Masiero e Caseiro, 2012:10); também, pode citar-se o caso da expansão das empresas JBS e Minerva (de processamento de carne) que também se instalaram no Paraguai, beneficiando-se por esse esquema. 
brasiguaios surgem, frequentemente, como principal alvo das denúncias, pois, além de sua presença notável no território, essa instalação foi circunscrita por profundas irregularidades.

Por último, verifica-se que ambos os governos, brasileiro e paraguaio, têm colaborado direta ou indiretamente para o avanço do agronegócio no país, apoiando o aprofundamento da integração dos capitais e das forças econômicas brasileiras à estrutura agroexportadora do Paraguai.

\section{4}

\section{Considerações finais do capítulo}

Definir o papel dos capitais, empresários e produtores brasileiros no desenvolvimento do modelo do agronegócio no Paraguai - e na dinâmica de integração do país à cadeia global de produção agrícola e agroindustrial - é uma tarefa complexa, pois, esses processos se consolidam em meio a um conjunto emaranhado de relações econômicas, envolvendo diferentes atores, de diversos portes e origens.

Em primeiro lugar, tem-se que a expansão das forças econômicas brasileiras no Paraguai está relacionada ao fato que, nas últimas décadas, a agricultura e agroindústria brasileiras experimentaram um desenvolvimento relativamente maior na região, assumindo características específicas de acordo com o momento em foco, que precisam ser distinguidas. Nesse sentido, identificam-se dois momentos principais:

(a) o primeiro, entre as décadas de 1960-1970, onde a participação brasileira ganhou forma no projeto de colonização da região fronteiriça do Paraguai, empreendimento que contou com incentivos públicos de ambos os lados da fronteira, e que envolveu empresas e produtores rurais brasileiros de diferentes portes e condições econômicas;

(b) o segundo, referente às duas últimas décadas (1990-2010), onde os impactos da "colonização brasileira" continuam a desdobrar-se - embora o fluxo de migração de produtores tenha praticamente cessado: de um lado, tem-se a consolidação de grandes produtores e empresários brasileiros no setor (que são também grandes proprietários de terra); por outro, verificam-se novos processos de expansão da fronteira agrícola - para áreas "internas", e para novas regiões, 
como o Chaco paraguaio - liderados pelos grupos já instalados nos país (de brasileiros ou "brasiguaios"), e por novos grupos. Além disso, constata-se a expansão dos capitais e empreendimentos brasileiros para outros ramos da agroindústria - como o de processamento de carne e, de forma incipiente, para o setor de elaboração de biocombustíveis - que estão relacionados aos novos desenvolvimentos da agroindústria no Brasil.

Assim, tem-se que a participação brasileira no desenvolvimento do agronegócio no Paraguai assumiu diferentes formatos ao longo do tempo, indo além da participação na dinâmica de produção agrícola (de soja) - embora essa seja, ainda, a sua principal forma de atuação no país.

Em termos da estrutura e das dinâmicas atuais da cadeia do agronegócio como um todo - contexto em que se identificam fortes tendências de concentração e oligopolização ao longo dos diferentes segmentos, indicando padrões de hierarquização e subordinação entre os distintos agentes envolvidos - as análises realizadas sugerem que as forças econômicas brasileiras cumpririam um papel de intermediário (ou subsidiário) no processo de desenvolvimento e internacionalização da agricultura paraguaia, na medida em que a sua atuação está sujeita ao grau de dominação dos segmentos da cadeia pelas firmas transnacionais. Com feito, a expansão dos capitais, empresários e produtores brasileiros no Paraguai tem acontecido, maiormente, no segmento da produção que é também o menos procurado pelas firmas transnacionais. Contudo, isso não significa que a sua participação seja menos importante, pois, além de terem sido os principais responsáveis pela difusão do modo de produção empresarial na agricultura no país, atualmente, os empresários e produtores brasileiros controlam uma ampla parcela da produção das commodities agrícolas, acumulando também grandes superfícies de terras sob sua propriedade.

Nesse contexto de divisão de tarefas e hierarquização, não se verificam grandes desentendimentos entre o grupo das corporações transnacionais e os demais grupos das firmas estrangeiras, empresas e cooperativas locais, que participam da dinâmica do agronegócio evidenciando uma forte convergência de interesses - conforme se verificou na atuação dos principais grêmios empresariais do setor. As polêmicas que surgem nesse âmbito, em geral, assumem uma conotação de disputa pela apropriação de uma maior parcela dos excedentes gerados nas atividades em questão. 
Por outro lado, a divisão de tarefas entre esses grupos deriva em implicações sociais e políticas distintas para cada um. Conforme apontado anteriormente, ao distanciar-se das atividades efetivas de produção agrícola, as firmas transnacionais afastam-se também dos principais conflitos que acompanham à expansão do agronegócio no país - que emergem, fundamentalmente, em torno da questão da distribuição do uso e do acesso à terra. Já, as demais firmas e empresários individuais que operam diretamente no segmento da produção adquirem maior visibilidade, na medida em que participam diretamente dessas dinâmicas de concentração no uso e na propriedade da terra, tornado-se alvo automático das reivindicações em torno da questão agrária. Nesse contexto, os empresários e produtores brasileiros e "brasiguaios" ganham destaque dentre os estrangeiros instalados no país, por conta de sua forte presença no setor, e também em função dos aspectos históricos e institucionais que proporcionaram a sua consolidação na estrutura agrária do Paraguai.

Em suma, a participação brasileira no desenvolvimento do agronegócio no Paraguai constitui um fenômeno complexo e heterogêneo. Pode-se dizer que, em grande medida, isso é um reflexo das ambiguidades que caracterizam o fato de o Brasil conseguir um maior desenvolvimento relativo de sua economia, mas ainda sujeitar-se, amplamente, às determinações dos monopólios econômicos internacionais. Por outro lado, trata-se de um fenômeno em constante evolução, que se desdobra, atualmente, em um contexto de aprofundamento da integração dos mercados e sistema produtivos de ambos os países (e destes, com os mercados e sistemas produtivos mundiais), ganhando relevância atual, e merecendo, maiores estudos e análises mais aprofundadas. 


\section{6. \\ Considerações finais}

O presente trabalho nasceu do desejo de avançar na compreensão do papel dos capitais, empresários e produtores brasileiros no desenvolvimento da agricultura capitalista (ou agronegócio) no Paraguai nas últimas décadas. Nos estudos sobre o tema, o peso dessa participação costuma ser muito realçado em função dos enfoques adotados - em geral, mais centrados na questão da propriedade e utilização da terra - levando a argumentar, por exemplo, sobre a consolidação de novas economias de enclave, em referência ao formato característico de penetração e instalação do capital internacional no início do século XX (só que, desta vez, comandadas pelo capital brasileiro). O protagonismo das forças econômicas brasileiras nos conflitos em torno do avanço do modelo do agronegócio no país também alimenta e justifica o amplo destaque que recebem nos estudos. No contexto dessas análises, porém, outros elementos importantes que interagem na consolidação desse modelo no país são, diversas vezes, ofuscados, e precisam, então, ser resgatados a fim de discriminar melhor o papel dos agentes econômicos brasileiros. Dilatando a perspectiva de análise, encontramo-nos com uma estrutura complexa, associada a uma dinâmica mais ampla de expansão imperialista do agronegócio na região, na qual o Brasil e suas forças econômicas assumem um papel subsidiário, atravessado de ambiguidades.

A proposta do trabalho - de discutir a respeito do papel dos capitais, empresários e produtores brasileiros no desenvolvimento do agronegócio no Paraguai utilizando um enfoque ampliado - começou, assim, a ser avançada construindo-se, em primeiro lugar, o marco teórico para a análise. Como base, foram adotadas as contribuições da chamada "vertente marxista" das teorias da dependência, corrente que se dedica ao estudo das especificidades do desenvolvimento do capitalismo nos países da América Latina, mais do que qualquer outra vertente teórica. Seguindo as suas principais premissas, ressaltouse a lógica monopolista que caracteriza a expansão mundial do capital (a partir das economias centrais) e o caráter descapitalizador que assume nas economias 
periféricas, ao procurar, antes que nada, ampliar as bases de sua acumulação por meio dessa expansão (ou "integração" dos sistemas produtivos nacionais).

Assim, quando as sociedades latino-americanas recebem esses fluxos de capitais - como aconteceu de forma marcante na década de 1970, e também ao longo da década de 1990 - experimentam, de fato, um maior desenvolvimento econômico. Porém, em função de sua inserção desvantajosa no esquema da divisão internacional do trabalho, essas nações (dependentes) abrigam mecanismos que buscam compensar pela transferência de valor aos países centrais, e que acabam resultando em uma ampla reprodução das condições de subdesenvolvimento nas suas sociedades. Nesse contexto, alguns países dependentes como o Brasil, conseguiram atingir um maior desenvolvimento relativo de suas forças econômicas, inaugurando uma nova "etapa" de seu desenvolvimento capitalista (onde também precisam se expandir a fim de assegurar a reprodução dos capitais investidos no país). Esse fenômeno foi analisando, principalmente, por Ruy M. Marini - quem o chamou de "subimperialismo" - e referiu-se, essencialmente, ao caso brasileiro (sendo a expansão para o Paraguai uma de suas mais notáveis manifestações).

$\mathrm{Na}$ elaboração desse marco interpretativo enfrentaram-se dois desafios. O primeiro, de ressaltar a relevância atual das premissas e da questão da dependência e do subimperialismo, a despeito da especificidade histórica de seu surgimento e da frequente marginalização que essas contribuições sofreram ao longo do tempo (e até hoje) nos debates públicos e acadêmicos. Embora o processo de atualização dessas teorias se encontre ainda em uma fase incipiente sendo uma tarefa assumida por diversos estudiosos de diferentes países - os debates em andamento tem sido intensos e, em geral, convergem em apontar para a relevância atual das premissas, principalmente, perante o atual acirramento dos monopólios internacionais, dos processos de integração produtiva, e em face da emergência de novas manifestações do subimperialismo brasileiro.

O segundo desafio foi atrelar essas premissas ao âmbito da agricultura que, frequentemente, ficou relegado a um segundo plano nas abordagens da economia política a respeito do desenvolvimento. Para realizar essa ponte, foram resgatadas contribuições de outras disciplinas (como a Sociologia Rural), mais tradicionalmente orientadas a estudar os processos em torno da agricultura. Dessa forma, foi possível evidenciar a centralidade da agricultura na configuração das 
relações imperialistas e de dependência ao longo do século XX e, especialmente, no momento atual. Ao ressaltar que a agricultura não é uma atividade própria das sociedades periféricas (ou dependentes), esses estudos contribuíram para problematizar o esquema da divisão internacional do trabalho - mostrando que se trata de uma estrutura mais complexa, que vai além da simples divisão de tarefas - e estabelecer um proveitoso diálogo com as reflexões atuais da teoria marxista da dependência em torno dessa questão.

Com efeito, embora o viés "urbano-industrial" tenha sido persistente nos estudos dos dependentistas marxistas, o questionamento do esquema da DIT ocupou sempre uma parte importante das reflexões de seus intelectuais - como se pode constatar nas análises de Marini (1977) a respeito dos processos de industrialização dos países da América Latina e do surgimento de "centro médios" de acumulação na década de 1970, que passavam a "desafiar o modelo simples de centro-periferia". Da mesma forma, continua a ser um ponto amplamente discutido nos debates atuais sobre a questão da dependência. Ao renovar as categorias de análise, autores contemporâneos chamam a atenção para a diferença entre a essência dos processos e as formas pelas quais se manifestam. Dessa forma, argumentam que a divisão internacional do trabalho (isto é, a essência) persiste, mas vai além da simples divisão de tarefas (isto é, das formas que assume). Nesse sentido, o declínio da indústria manufatureira e a concomitante ascensão das indústrias agrícolas (agronegócio) ou extrativas, na maior parte dos países latino-americanos, não significa uma regressão do desenvolvimento do capitalismo em seus territórios (ou a nível mundial), pelo contrário, consiste no contínuo aprofundamento desses desenvolvimentos e de suas tendências de diferenciação interna e externa.

Assim, a combinação dessas reflexões - sobre as teorias da dependência e sua relevância contemporânea, e sobre a centralidade da agricultura nas relações econômicas internacionais - foi crucial para compreender os padrões atuais das relações imperialistas e de dependência (e também subimperialistas) na América Latina. Os desafios surgidos na elaboração desse marco teórico, conforme apontados anteriormente, passaram a constituir questões de pesquisa secundárias, ocupando um espaço importante do trabalho. O aprofundamento dessas reflexões teóricas, porém, fugiu do escopo do presente trabalho. Sugere-se, portanto, que as mesmas sejam retomadas e nutridas em futuras pesquisas. 
Após essa primeira etapa, passou-se à parte mais específica da pesquisa, referente à coleta e análise de dados atuais sobre a expansão do modelo do agronegócio no Paraguai e a participação brasileira nesse processo. Seguindo a proposta de adoção de uma perspectiva ampla, a análise foi realizada em dois níveis diferentes: (1) Primeiro, observaram-se as tendências de consolidação do agronegócio na América Latina - especificamente, na região do Cone Sul - a fim de compreender o caráter da inserção desses países nessa dinâmica; (2) Segundo, analisou-se a configuração do modelo do agronegócio no Paraguai, verificandose, com maior detalhe, os principais agentes envolvidos e suas formas de atuação.

Na primeira parte da análise, foi explorada a hipótese do desenvolvimento desigual da agricultura capitalista entre os países da região. Mais particularmente, procurou-se averiguar se seria possível distinguir uma "divisão regional do trabalho" no âmbito da agricultura entre esses países (principalmente, entre o Brasil e o Paraguai). Considerando a conjuntura atual, em que ambos os países evidenciam um padrão econômico similar de proeminência das atividades agroexportadoras, tal análise se mostrou crucial para discriminar melhor as causas e modalidades da participação brasileira no desenvolvimento do agronegócio no Paraguai, que permanece forte (conforme se verifica na segunda parte da análise).

Com base nos dados apresentados e analisados no $4^{\circ}$ capítulo, constatou-se que o desenvolvimento do agronegócio na região do Cone Sul segue, amplamente, as determinações das corporações transnacionais do agronegócio, e que, esses países se inserem na dinâmica, basicamente, como importantes produtores e exportadores de commodities agrícolas (especialmente, de soja). Por outro lado, distinguiram-se também evidências de um desenvolvimento diferenciado da agricultura capitalista nesses países, que resulta tanto da distribuição desigual dos fluxos de IED, como das estruturas socioprodutivas específicas de cada país.

Na América Latina, o Brasil é o país que mais tem atraído os fluxos de IED orientados para a agricultura e atividades relacionadas nos últimos anos. Nas dinâmicas de estrangeirização na região - que assumem um caráter "intraregional" - o Brasil também se destaca, colocando-se como importante impulsionador do fenômeno. $\mathrm{Na}$ breve análise sobre a trajetória do desenvolvimento do agronegócio no Brasil, de fato, constatou-se que o país conseguiu incorporar um maior número de segmentos da cadeia agrícola e agroindustrial global em seu território, como a produção de fertilizantes e de 
máquinas agrícolas (embora permaneçam sob o controle do capital internacional). Em certos ramos, como o da produção e processamento de carne, e o da elaboração de biocombustíveis, o Brasil tem adquirido ainda maior transcendência - sobretudo, a partir da projeção de suas próprias firmas transnacionais (como a JBS-Friboi). Nesse contexto de diferenciação, a emergência de um padrão de trocas comerciais desiguais (isto é, de "intercâmbio desigual") entre o Brasil e os demais países da região, especialmente, com os países menores, é quase inevitável - conforme se pôde verificar no caso das trocas comerciais entre o Brasil e o Paraguai, apresentado no final do $4^{\circ}$ capítulo.

De qualquer forma, as análises realizadas ao longo desse capítulo deixaram claro que a ascensão internacional do agronegócio brasileiro se restringe às determinações dos oligopólios internacionais do agronegócio, comandados pelas corporações transnacionais do setor. Com relação às commodities agrícolas, por exemplo, apesar de ser um grande produtor, o Brasil não possui grandes firmas exportadoras ou processadoras que consigam competir a nível global. Trata-se de um aspecto importante a ser considerado no estudo de sua expansão para os países vizinhos. Portanto, argumenta-se que é possível falar da consolidação de um padrão de divisão regional do trabalho no âmbito do desenvolvimento do agronegócio na região, que se subordina ao esquema mais amplo de divisão internacional do trabalho.

A partir dessas considerações, prosseguiu-se à segunda parte da análise empírica, referente ao estudo da configuração do modelo do agronegócio no Paraguai e da participação brasileira nessa dinâmica. O capítulo dedicado a essa análise começa com uma breve revisão histórica do desenvolvimento da agricultura capitalista no Paraguai (que ganhou impulso ao longo dos anos 1970), a fim de distinguir os padrões atuais desse processo. Naquele período, a participação brasileira se destacou, essencialmente, pela instalação massiva de produtores rurais brasileiros na região fronteiriça do país, que migravam do Brasil em busca de melhores oportunidades econômicas. Esses migrantes brasileiros foram os principais responsáveis pela introdução de novas técnicas e tecnologias de produção no campo paraguaio, e pela expansão da fronteira agrícola no país.

Atualmente, a participação de produtores e empresários brasileiros continua a ser marcante no segmento da produção primária - os produtores brasileiros e "brasiguaios" são responsáveis por mais da metade da soja produzida 
no país - contribuindo, diretamente, para a consolidação das grandes unidades de produção agrícola e para a abertura de novas áreas de cultivo (tendências que, conforme explicado no capítulo, só se identificam através do cruzamento de diversos dados oficiais, e de pesquisas complementares). Hoje, a participação brasileira no agronegócio paraguaio também se aprofunda por meio da expansão para novos ramos (como de produção e processamento de carne).

Considerando a estrutura atual da cadeia do agronegócio como um todo tem-se que, enquanto os produtores e empresários brasileiros têm proeminência na esfera da produção primária, os demais segmentos relacionados a essas atividades - como o de fornecimento de insumos agrícolas e o de processamento e exportação dos bens agrícolas - são amplamente dominados pelas corporações transnacionais do agronegócio, conforme pôde contatar-se pela sua participação nos volumes totais de comércio do país.

Todavia, embora representem o "elo mais fraco" da cadeia agroindustrial, a proeminência dos agentes brasileiros no segmento da produção os coloca na linha de frente das dinâmicas sociopolíticas. Considerando as breves análises realizadas a respeito dessas dinâmicas, constatou-se que há uma forte convergência de interesses entre empresários e grandes proprietários paraguaios e brasileiros, como se verifica na conformação e atuação dos principais grêmios empresariais do país. Esses grupos agem em conjunto tanto para promover o modelo, como para frear as políticas adversas a seu avanço (por exemplo, os esforços relacionados à regularização das propriedades rurais). Já no contexto dos conflitos em torno do avanço do modelo (especialmente, aqueles relacionados à utilização e acesso à terra), os empresários e produtores brasileiros aparecem como principais alvo das denúncias. Por fim, o $5^{\circ}$ capítulo ressaltou que ambos os governos, brasileiro e paraguaio, têm atuado, ao longo das últimas décadas, no sentido de facilitar a consolidação do modelo do agronegócio no Paraguai e a participação brasileira nesse processo.

Em suma, a participação brasileira no desenvolvimento da agricultura capitalista no Paraguai constitui um fenômeno intricado, conforme pode ser constatado nas suas diferentes manifestações ao longo das últimas décadas. Por vezes assumiu um caráter mais espontâneo, principalmente, nos primeiros anos da migração de produtores rurais brasileiros à região fronteiriça do Paraguai (caráter reforçado por uma relativa negligência do governo paraguaio). Com a 
promulgação de políticas mais explícitas de incentivo à colonização e a chegada de produtores e de investimentos de maior porte, a participação brasileira foi ganhando um tom mais estratégico. O fenômeno pode ser interpretado como um processo de exportação das contradições do Brasil, especialmente, ao considerarem-se os primeiros anos da migração brasileira para o Paraguai (19601970), onde uma parcela importante do fluxo de migrantes foi constituída por produtores de pequeno porte, que estavam sendo expulsos de suas regiões pelo forte avanço da agroindústria no Brasil. Mas também é entendido como o processo de expansão externa dos capitais brasileiros na busca por recursos $e$ matérias-primas mais baratos que possibilitem a sua contínua reprodução conforme se percebe pela chegada ao Paraguai de produtores e de investimentos brasileiros de maior porte, e pela expansão (em anos recentes) desses investimentos para novos segmentos. Por último, levando em consideração a atuação das corporações transnacionais no esquema do agronegócio no Paraguai (e também a sua atuação em nível global), a participação dos agentes econômicos brasileiros nessa dinâmica assume um lugar secundário (ou subsidiário). Contudo, em termos sociais e políticos, consiste em uma participação mais visível que, frequentemente, constitui o pivô dos conflitos agrários em torno do avanço do modelo do agronegócio no país.

Por fim, trata-se de uma heterogeneidade que a teoria do subimperialismo auxilia a captar e compreender. O subimperialismo descreve um grau de desenvolvimento econômico atingido pelo Brasil (a etapa dos monopólios e do capital financeiro, e também da expansão externa) que acontece sem o país ter superado a sua condição de dependência. Nesse contexto, além experimentar o aprofundamento das contradições dessa lógica de desenvolvimento em seu território, o Brasil passa a contribuir para o acirramento das contradições do desenvolvimento dependente nas nações para as quais exporta seus capitais e produtos (ou onde procura recursos), como o Paraguai. Assim, é importante ressaltar que não consiste em uma mera "exploração do Paraguai pelo Brasil", como muitas vezes se mal entende. Trata-se de uma dinâmica mais complexa de exploração da mão de obra e dos recursos naturais desses países pelo capital internacional em associação com os capitais e às classes dominantes brasileiras e também paraguaias. 
Em outras palavras, todos os aspectos analisados ao longo deste trabalho, em última instância, dizem respeito a um mesmo processo: o da expansão da agricultura capitalista (e da dominação imperialista) na região. Sendo assim, o questionamento em torno do avanço do agronegócio, e a elaboração de políticas que busquem corrigir seus efeitos nocivos no Paraguai, devem ir além da consideração do papel dos agentes econômicos brasileiros nessa dinâmica, colocando em questão o modelo de desenvolvimento e integração da agricultura como um todo.

De qualquer maneira, a discussão sobre o papel do Brasil e das suas forças econômicas no desenvolvimento do agronegócio no Paraguai precisa ser aprofundada e refinada, dada a complexidade do fenômeno, e por tratar-se de um aspecto determinante da sociedade paraguaia. Nesse sentido, foram identificadas algumas questões específicas que merecem maior atenção, e que são apontadas a seguir como sugestões para futuras pesquisas sobre o tema: (1) a análise sobre os desenvolvimentos em torno de novos segmentos e cadeias agroindustriais no Paraguai, onde a participação brasileira é mais contundente (por exemplo, na produção e processamento de carnes, e na produção de biocombustíveis); (2) estudos mais aprofundados sobre a atuação social e política dos grupos dominantes (locais e estrangeiros) do agronegócio no Paraguai; (3) estudos específicos a respeito da questão da superexploração no contexto da industrialização da agricultura nesses países, que implicam, tanto em trabalhos de aprofundamento dos debates teóricos sobre o desenvolvimento da agricultura capitalista (conforme sugerido anteriormente), como na realização de pesquisas de campo mais extensas. 


\section{7. \\ Referências bibliográficas}

ABC COLOR. Expectativa por translado de Nacunday. Jornal ABC Color, 27/03/2014. Disponível em: http://www.abc.com.py/edicionimpresa/economia/expectativa-por-traslado-de-nacunday-1228842.html. Acesso em: 29 de março de 2014.

Cinco multinacionales manejan $80 \%$ del comercio de la soja de Paraguay. Jornal ABC Color, 25/07/2013. Disponível em: http://www.abc.com.py/edicion-impresa/economia/cinco-multinacionalesmanejan-80-del-comercio-de-la-soja-de-paraguay-599567.html. Acesso em: 28 de novembro de 2013. [2013a]

Megaproyecto de procesamiento de soja recibirá un préstamo del BID. Jornal ABC Color, 29/06/2013. Disponível em: http://www.abc.com.py/edicion-impresa/economia/megaproyecto-deprocesamiento-de-soja-recibira-un-prestamo-del-bid-589883.html. Acesso em: 30 de maio 2014. [2013b]

El $60 \%$ de frigoríficos exportadores son controlados por firmas brasileñas. Jornal ABC Color, 27/11/2012. Disponível em: http://www.abc.com.py/edicion-impresa/economia/el-60-de-frigorificosexportadores-son-controlados-por-firmas-brasilenas-482655.html. Acesso em: 30 de maio de 2014. [2012a]

Gremios productivos apoyan a Franco. Jornal ABC Color, 28/06/2012. Disponível em: http://www.abc.com.py/nacionales/gremiosproductivos-apoyan-gobierno-de-franco-420056.html. Acesso em: 29 de março de 2014. [2012b]

Sojeros piden derogar decreto. Jornal ABC Color, 17/07/2012.

Disponível em: http://www.abc.com.py/edicion-impresa/politica/sojeros-pidenderogar-decreto-427181.html. Acesso em: 29 de março de 2014. [2012c]

ABENTE BRUN, D. El Paraguay Actual. 1era. Parte (1989-1998). Colección 'La Gran Historia del Paraguay', n. 14. Asunción: El Lector, 2010.

ASSOCIAÇÃO BRASILEIRA DA INDÚSTRIA DE MÁQUINAS E EQUIPAMENTOS (ABIMAQ). Informações sobre o programa de crédito "BNDES Exim" e "BNDES Exim Automático". Disponível em: http://www.abimaq.org.br/Arquivos/Html/DEFI/Dowloads/apres_bndes_exim_aut final21.02.14.pdf. Acesso em: 24 de maio de 2014. 
AGÊNCIA BRASILEIRA DE COOPERAÇÃO (ABC). Sobre a ABC e os projetos de cooperação técnica em agricultura na América Latina e na África. Disponível em: http://www.abc.gov.br/projetos/. Acesso em: março de 2014.

ARCE, L. El boom de la industria cárnica en Paraguay. Observatorio de Economía Internacional (OBEI) - Centro de Análisis y Difusión de la Economía Paraguaya (CADEP). Enero 2012. Disponível em: http://www.cadep.org.py/2012/01/la-industria-carnica-en-paraguay/. Acesso em: 26 de agosto de 2013.

ASSOCIAÇÃO BRASILEIRA DA INDÚSTRIA DE ÓLEOS VEGETAIS (ABIOVE). Dados estatísticos sobre o complexo da soja. Disponíveis em: www.abiove.org.br. Acesso em: 19 de fevereiro de 2014.

ASSOCIAÇÃO NACIONAL DOS FABRICANTES DE VEÍCULOS AUTOMOTORES (ANFAVEA). Anuário da Indústria Automobilística brasileira: 2013. São Paulo: ANFAVEA, 2013. Disponível em: www.anfavea.com.br. Acesso em: 10 de maio de 2014.

BANDEIRA, L. A. M. As políticas neoliberais e a crise na América do Sul. Revista Brasileira de Política Internacional, 45 (2), 2002, p. 135-146.

BEIGEL, F. Vida, muerte y resurrección de las "Teorías de la Dependencia". In: CLACSO (Org.). Crítica y Teoría en el Pensamiento Social latino-americano. Buenos Aires: CLACSO, 2006, p. 287-326. Disponível em: http://biblioteca.clacso.edu.ar/ar/libros/becas/critica/critica.html. Acesso em: 30 de dezembro de 2013.

BANCO CENTRAL DEL PARAGUAY (BCP). Boletín Trimestral de Comercio Exterior (1961 - $3^{\circ}$ trimestre de 2013). Disponível em: https://www.bcp.gov.py/estadisticas-economicas-i364. Acesso em: 17 de março de 2014. [2014a].

Extranjera Directa (2003- $4^{\circ}$ trimestre de 2012). Disponível em: https://www.bcp.gov.py/anexo-estadistico-inversion-extranjera-directa-i378.

Acesso em: 18 de março de 2014. [2014b].

BANCO NACIONAL DE DESENVOLVIMENTO (BNDES). Governo cria Exim Brasil como subsidiária do BNDES. Notícias BNDES, maio de 2010. Disponível em:

http://www.bndes.gov.br/SiteBNDES/bndes/bndes_pt/Institucional/Sala_de_Impre nsa/Noticias/2010/exportacao/20100505_Exim_Brasil.html. Acesso em: 24 de maio de 2014.

BNDES e BB assinam contrato inédito para financiamento de exportações brasileiras para AL. Notícias BNDES, junho de 2011. Disponível em:

http://www.bndes.gov.br/SiteBNDES/bndes/bndes_pt/Institucional/Sala_de_Impre nsa/Noticias/2011/todas/20110601_bb.html. Acesso em: 24 de maio de 2014. 
BORDA, D. La economía política del crecimiento, pobreza y desigualdad en el Paraguay (1968-2010). In: ABENTE, D.; BORDA, D. (eds.). El Reto del Futuro. Asumiendo el legado del Bicentenario. Asunción: Ministerio de Hacienda de la República del Paraguay y Banco de Desarrollo de América Latina (CAF), 2011, p. 57-113.

BORÓN, A. Teoría (s) de la Dependencia. Realidad Económica, Instituto Argentino para el Desarrollo Económico, n. 238, 2008, p. 20-43. Disponível em: http://www.iade.org.ar/uploads/c87bbfe5-15d6-9281.pdf. Acesso em: $21 \mathrm{de}$ novembro de 2013.

BORRAS, S. M.; FRANCO, J. C.; GÓMEZ, S.; KAY, C.; SPOOR, M. Land Grabbing in Latin America and the Caribbean. The Journal of Peasant Studies, v. 39, n. 3-4, July-October 2012, p. 845-872.

BORTOT, I. J. Brasil quer resolver questão migratória e fundiária dos brasiguaios. Agência Brasil, 30/10/2012. Disponível em: http://memoria.ebc.com.br/agenciabrasil/noticia/2011-10-30/brasil-querresolver-questao-migratoria-e-fundiaria-dos-brasiguaios. Acesso em: 29 de março de 2014.

BOSCHI, R.; GAITÁN, F. Intervencionismo Estatal e Políticas de Desenvolvimento na América Latina. Caderno CRH, Salvador, v.21, n.53, p. 302-322, maio/ago 2008.

BRIEGER, P. De la década perdida a la década del mito neoliberal. In: GAMBINA, J. (org.). La globalización económico-financiera: su impacto en América Latina. Buenos Aires: CLACSO, 2002, p 341-355.

BRÍTEZ, E.; NUMAN C., J. El Paraguay Actual. 2nda. Parte (1998-2010). Colección ‘La Gran Historia Del Paraguay’ n. 15. Asunción: El Lector, 2010.

BUENO, F.; SEABRA, R. A teoria do subimperialismo brasileiro: notas para uma (re) discussão contemporânea. In: Anais do VI Colóquio Internacional Marx e Engels, Centro de Estudos Marxistas - IFCH/UNICAMP. Campinas, 2009. Disponível em: http://www.ifch.unicamp.br/formulario_cemarx/selecao/2009/trabalhos/a-teoriado-subimperialismo-brasileiro.pdf. Acesso em: 11 de novembro de 2013.

CAMPOS, D. Reforma Agraria: una causa nacional pendiente. Asunción: Editorial Arandurã, 2013.

Actualización del diagnóstico sobre brasileros residentes en la Región Oriental de la República del Paraguay: Informe final. Asunción: Sociedad de Estudios Rurales y Cultura Popular (SER), marzo de 1999.

CÁMARA PARAGUAYA DE EXPORTADORES Y COMERCIALIZADORES DE CEREALES Y OLEAGINOSAS (CAPECO). Informaciones institucionales sobre el gremio y estadísticas sobre la producción y exportación de granos y cereales en el Paraguay. Disponível em: www.capeco.org.py. Acesso em: fevereiro/março de 2014. 
CÁMARA PARAGUAYA DE PROCESADORES Y EXPORTADORES DE OLEAGINOSAS Y CEREALES (CAPPRO). Informaciones institucionales sobre el gremio y estadísticas sobre la producción, procesamiento y exportación de granos y cereales en el Paraguay. Disponível em: http://cappro.org.py/. Acesso em: maio de 2014.

CARBONE, R.; SOLER, L. (Eds.). Franquismo en Paraguay: El Golpe. Buenos Aires: El 8vo. Loco, 2012.

CARCANHOLO, M. D. (2013). (Im) precisiones acerca de la categoría superexplotación de la fuerza de trabajo. Razón y Revolución, n. 25, 2013, p. 91124.

CARDOSO, F. H.; FALETTO, E. Dependencia y Desarrollo en América Latina. Buenos Aires: Siglo XXI, 1977. [versão eletrônica para fins didáticos]. Disponível em: http://www.ceipil.org.ar/wpcontent/uploads/2011/CURSO/unidad\%201-Cardoso\%20y\%20Faletto.pdf.

Acesso em: 30 de dezembro de 2013.

CENTRO DE IMPORTADORES DEL PARAGUAY (CIP). Informaciones sobre el ranking de exportadores e importadores del Paraguay (años 2009 a 2013). Disponível em: http://www.cip.org.py/. Acesso em: 8 de março de 2014.

CEPALSTAT. Bases de datos y publicaciones estadísticas de la CEPAL. Disponível

em: http://estadisticas.cepal.org/cepalstat/WEB_CEPALSTAT/Portada.asp. Acesso em: maio/junho de 2014.

CLEMENTS, E. A.; FERNANDES, B. M. Land Grabbing, Agribusiness and the Peasantry in Brazil and Mozambique. Agrarian South: Journal of Political Economy, 2 (1), 2013, p. 41-69.

COMISIÓN ECONÓMICA PARA AMÉRICA LATINA (CEPAL). La inversión extranjera directa en América Latina y el Caribe, 2012. Santiago de Chile: CEPAL/ONU, junho de 2013.

CONSEJO LATINOAMERICANO DE CIENCIAS SOCIALES - CLACSO (Org.). Crítica y Teoría en el Pensamiento Social latino-americano. Buenos Aires: CLACSO, 2006, 448 p. Disponível em: http://biblioteca.clacso.edu.ar/ar/libros/becas/critica/critica.html. Acesso em: 30 de dezembro de 2013.

E'A. FAO recordó que 1.600.000 personas sufren hambre em Paraguay. Jornal digital E'a, 17/10/2012. Disponível em: http://ea.com.py/fao-recordo-que-1-600000-personas-sufren-hambre-en-paraguay/. Acesso em: 28 de abril de 2014.

EMPRESA BRASILEIRA DE PESQUISA AGROPECUÁRIA (EMBRAPA). Sobre a Embrapa e seus projetos recentes de cooperação técnica na América do Sul. Disponível em: www.embrapa.br. Acesso em: maio/junho de 2014.

ETC GROUP. El carro delante del caballo. Semillas, suelos y campesinos: ¿Quién controla los insumos agrícolas?. ETC Group, comunicado n. 111, 
setembro de 2013. Disponível em: www.etcgroup.org. Acesso em: 18 de maio de 2014.

Who Will control the Green Economy?. ETC Group, comunicado n. 107, novembro 2011. Disponível em: www.etcgroup.org. Acesso em: 16 de julho de 2013.

Who Owns Nature? Corporate power and the final frontier in the commodification of life. ETC Group, comunicado n. 100, novembro 2008. Disponível em: www.etcgroup.org. Acesso em: 16 de julho de 2013.

FAOSTAT. Base de dados estatísticos da FAO. Disponível em: http://faostat.fao.org. Acesso em: maio/junho de 2014.

FEDERAÇÃO DAS INDÚSTRIAS DO ESTADO DE SÃO PAULO (FIESP). Empresários destacam vantagens competitivas para investimentos no Paraguai. Portal FIESP: Notícias, 03/04/2013. Disponível em: http://www.fiesp.com.br/noticias/empresarios-destacam-vantagens-competitivaspara-investimentos-no-paraguai/. Acesso em: 23 de março de 2014. [2013a]

Oportunidades de investimento no Paraguai
(apresentações). Portal atualização em 3 de abril de 2013. Disponível em: http://www.fiesp.com.br/indices-pesquisas-e-publicacoes/apresentacoes-

oportunidades-de-investimentos-no-paraguai/. Acesso em: 29 de março de 2014. [2013b]

FERNANDES, B. M. A geopolítica da questão agrária mundial. Boletim DATALUTA, Núcleo de Estudos, Pesquisas e Projetos de Reforma Agrária (NERA), número 18, junho de 2009. Disponível em: www.fct.unesp.br/nera. Acesso em: 12 de novembro de 2013.

(org.). Campesinato e agronegócio na América Latina: a questão agrária atual. São Paulo: Expressão Popular, 2008.

FERREIRA, C.; LUCE, M. S. Introdução. In: FERREIRA, C.; OSORIO, J.; LUCE, M. (Orgs.). Padrão de reprodução do capital: contribuições da teoria marxista da dependência. São Paulo: Boitempo, 2012, p. 9-20.

FOOD AND AGRICULTURE ORGANIZATION OF THE UNITED NATIONS (FAO-UN). Trends and impacts of foreign investments in developing country agriculture: Evidence from Case Studies. Rome: FAO-UN, 2013. Disponível em: www.fao.org. Acesso em: 10 de julho de 2013. [2013a]

FAO Statistical Yearbook 2013: World and Food agriculture. Rome: FAO-UN, 2013. Disponível em: www.fao.org. Acesso em: 9 de julho de 2013. [2013b]

Dinámicas del mercado de la tierra en América Latina y el Caribe: concentración y extranjerización. Roma: FAO, 2012. 
Future expansion of soybean (2005-2014): Implications

for food security, sustainable rural development and agricultural policies in the countries of MERCOSUR and Bolivia. Policy Assistance Series 3 (synthesis document). Santiago de Chile: FAO-UN, October, 2007.

FOGEL, R. Las tierras de Nacunday, Marina Kué y otras calamidades. Asunción: CERI/Servilibro, 2013.

. La estructura y la coyuntura en las luchas del movimiento campesino paraguayo. In: CLACSO. Una Nueva Ruralidad en América Latina?. Buenos Aires: CLACSO, 2001, p. 221-241. Disponível em: http://bibliotecavirtual.clacso.org.ar/clacso/gt/20100929015604/11fogel.pdf.

Acesso em: 2 de fevereiro de 2013.

Procesos de globalización y reestructuración agraria en el Cono Sur: El Caso Paraguayo. In: PIÑEIRO, D. E. (comp.). Globalización, Integración Regional y Consecuencias Sociales sobre la Agricultura. Montevideo: AUGM/UNESCO/Universidad de la República, 1996, p. 10-28.

Tierra y democracia: La Lucha de los campesinos paraguayos. Nueva Sociedad, n. 96, julio-agosto 1988.

FOGEL, R.; RIQUELME, M. (orgs.). Enclave Sojero: Merma de soberanía y pobreza. Asunción: Centro de Estudios Rurales Inter-disciplinares (CERI), 2005.

FORO PARAGUAY BRASIL (FPB). Informações institucionais sobre o Foro. Disponível em: http://www.fbp.org.py/. Acesso em: março de 2014.

FRANK, A. G. The Development of Underdevelopment. In: CHEW, S. C.; LAUDERDALE, P. (Eds.). Theory and methodology of world development: the writings of Andre Gunter Frank. New York: Palgrave Macmillan, 2010, p. 717. [original 1966]

FRIEDLAND, W. H. Agrifood globalization and commodity systems. International Journal of Sociology of Food and Agriculture - Special issue: Globalization. Vol. 12, 2004, p. 5-16.

FRITZ, T. Agroenergía en América Latina. Un estudio de caso de cuatro países: Brasil, Argentina, Paraguay y Colombia. Berlín: Pan Para el Mundo/FDCL, mayo 2008.

GALEANO, L. Paraguay and the Expansion of Brazilian and Argentinian Agribusiness Frontiers. Canadian Journal of Development Studies, vol. 33, n. 4, December 2012, 458-470. [2012a].

El Caso de Paraguay. In: FAO. Dinámicas del mercado de la tierra en América Latina y el Caribe: concentración y extranjerización. Roma: Organización de las Naciones Unidas para la Alimentación y la Agricultura (FAO), 2012, p. 407-434. [2012b]

Los campesinos y la lucha por la tierra. In: TELESCA, I. (coord.)

Historia del Paraguay. Asunción: Santillana, 2011. p. 357-374. [2011a] 
La nueva ruralidad: Transformaciones y desafíos del Paraguay rural contemporáneo. In: ABENTE, D.; BORDA, D. (eds.). El Reto del Futuro. Asumiendo el legado del Bicentenario. Asunción: Ministerio de Hacienda de la República del Paraguay y Banco de Desarrollo de América Latina (CAF), 2011, p. 155-189. [2011b]

GARCIA, B.P. et. al. O setor de máquinas agrícolas brasileiro e o comércio internacional. Revista Estudos do CEPE, n 27, janeiro-junho 2008, p. 24-43. Disponível em: http://online.unisc.br/seer/index.php/cepe/article/view/652. Acesso em: 10 de maio de 2014.

GIARRACA, N.; LEVY, B. Ruralidades latinoamericanas: Identidades y luchas sociales. Buenos Aires: CLACSO, 2004. Disponível em: http://bibliotecavirtual.clacso.org.ar/clacso/becas/20110124024946/giarraca.pdf. Acesso em: 30 de dezembro de 2013.

GIARRACA, N.; TEUBAL M. Del desarrollo agro-industrial a la expansión del agronegocio: el caso argentino. In: BERNARDES, B. M. (org.). Campesinato e Agronegócio na América Latina: A Questão Agrária Atual. São Paulo: Expressão Popular, 2008, p. 139-164.

GLAUSER, M. Extranjerización del Territorio Paraguayo. Asunción: BASEIS, 2009.

GOODMAN, D.; SORJ, B.; WILKINSON, J. Da lavoura às biotecnologias: agricultura e indústria no sistema internacional. Centro Edelstein de pesquisas sociais, 2008. Disponível em: www.bvce.org. Acesso em: 30 de dezembro de 2013.

GWYNNE R.; KAY, C. Latin America transformed: globalization and neoliberalism. In: GWYNNE, R; KAY, C. (Eds.) Latin America transformed: globalization and modernity. London: Hodder Education, 2004, p. 3-21.

HERKEN, J. C. Desarrollo capitalista, expansión brasilera y condiciones del proceso político en el Paraguay. Nueva Sociedad, n. 17, marzo-abril, 1975.

HILL, A. El milagro brasilero Del Paraguay: Evolución y perspectiva. Documento de trabajo n. 41. Asunción: Centro de Estudios y Documentación (CDE), 1993 [original 1982].

Cien años del Paraguay dentro de la División Internacional del Trabajo. La Evolución Económica reciente en una perspectiva histórica. Documento de discusión. Banco Paraguayo de Datos (BPD), setiembre de 1980 [Inédito].

INFOBAE. ONU: Paraguay es el país peor alimentado de Sudamérica. Jornal Infobae América, 22/05/2013. Disponível em: http://www.infobae.com/2013/05/22/1071913-onu-paraguay-es-el-pais-peoralimentado-sudamerica. Acesso em: 28 de abril de 2014.

JAMES, C. Global Status of Commercialized Biotech/GM Crops: 2013. ISAAA Brief n. 46 (Executive Summary). The International Service for the 
Acquisition of Agri-biotech Applications (ISAAA): Ithaca, NY, 2013. Disponível em: http://www.isaaa.org. Acesso em: 28 de maio de 2014.

KAY, C. Teorias estruturalistas e teoria da dependência na era da globalização neoliberal. In: SADER, E.; SANTOS, T. dos (coords.); MARTINS, C. E.; SOTELO VALENCIA, A. (Orgs.). A América Latina e os desafios da globalização. Ensaios em homenagem a Ruy Mauro Marini. Rio de Janeiro: Ed. PUC-RIO; São Paulo: Boitempo Editorial, 2009, p. 361-388.

KOHLHEPP, G. Colonización y desarrollo dependiente en el oriente Paraguayo. Revista Geográfica, n. 99, enero-junio 1984, p. 5-33.

LA NACIÓN. UGP asegura que amerita juicio político a Lugo. Jornal La Nación, 15/06/2012. Disponível em: http://www.lanacion.com.py/articulo/76430ugp-asegura-que-amerita-juicio-politico-a-lugo.html. Acesso em: 29 de março de 2014.

LÊNIN, V. I. O Imperialismo, Fase Superior do Capitalismo. [1916]. Disponível em: https://www.marxists.org/portugues/lenin/1916/imperialismo/capl.htm. Acesso em: 10 de maio de 2013.

LUCE, M. S. O subimperialismo, etapa superior do capitalismo dependente. Crítica Marxista, n. 36, 2013, p. 129-141. [2013a]

Brasil: ¿"nueva clase média" o nuevas formas de superexplotación de la clase trabajadora?. Razón y Revolución, n. 25, 2013, p. 125-151. [2013b]

A teoria do subimperialismo em Ruy Mauro Marini: contradições do capitalismo dependente e a questão do padrão de reprodução do capital. A História de uma categoria. Porto Alegre, 2011, 225 f. Tese (Doutorado em História). Instituto de Filosofia e Ciências Humanas, Universidade Federal de Rio Grande do Sul.

O subimperialismo brasileiro revisitado: a política de integração regional do governo Lula (2003-2007). Porto Alegre, 2007. Dissertação (Mestrado em Relações Internacionais). Instituto de Filosofia e Ciências Humanas, Universidade Federal de Rio Grande do Sul.

MAGDOFF, F; BELLAMY, J.; BUTTEL, F. H. An Overview. In: (Eds.). Hungry for profit: The agribusiness threat to farmers, food and the environment. New York: Monthly Review Press, 2000, p. 7-21.

MCMICHAEL, P. Global Food Politics. In: MAGDOFF, F; BELLAMY, J.; BUTTEL, F. H. (Eds.). Hungry for profit: The agribusiness threat to farmers, food and the environment. New York: Monthly Review Press, 2000, p. 125-143.

MARINI, R. M. La acumulación capitalista mundial y el sub-imperialismo. Cuadernos Políticos n. 12, Ediciones Era, México, abril-junio de 1977. Disponível em: www.marini-escritos.unam.mx. Acesso em: 17 de junho de 2012. 
Dialética da dependência. In: TRASPADINI, R.; STEDILE, J. P.

(Orgs.). Ruy Mauro Marini: Vida e Obra. São Paulo: Expressão Popular, 2005, p. 137-180. [original 1973]

Subdesenvolvimento e revolução. Florianópolis: Insular, 2012. [tradução da edição de 1976].

MARTINS, C. E. O pensamento social latino-americano e os desafios do século XXI. Comunicação e Política, v. 30, n.1, 2012, p. 25-51.

O pensamento latino-americano e o sistema mundial. In: CLACSO (Org.). Crítica y Teoría en el Pensamiento Social latinoamericano. Buenos Aires: CLACSO, 2006, p. 153-216. Disponível em: http://biblioteca.clacso.edu.ar/ar/libros/becas/critica/critica.html. Acesso em: 17 de outubro de 2013.

MASI, F. Atraer la inversión extranjera: ¿Desde el mercado o desde el estado? Revista Economía y Sociedad - CADEP, n. 7, abril de 2013, p. 19-22.

Los desafíos de una nueva inserción externa del Paraguay. In: ABENTE, D.; BORDA, D. (eds.). El Reto del Futuro. Asumiendo el legado del Bicentenario. Asunción: Ministerio de Hacienda de la República del Paraguay y Banco de Desarrollo de América Latina (CAF), 2011, p.115-153.

El caso paraguayo. In: CHUDNOVSKY, D. (Ed.). El boom de inversión extranjera directa en el MERCOSUR. Montevideo: Red MERCOSUR, 2001, p. 209-253.

MASIERO, G.; CASEIRO, L. C. Z. State Support for Emerging Market Multinationals: The Brazilian and Chinese experiences. Working Paper n. 10. UC-CIFF-IELAT, dec.2012.

MINISTERIO DE AGRICULTURA Y GANADERÍA (MAG). Censo Agropecuario Nacional 2008 - Volumen I. San Lorenzo: MAG, Dirección de Censos y Estadísticas Agropecuarias, 2008.

MINISTÉRIO DO DESENVOLVIMENTO, INDÚSTRIA E COMÉRCIO DO BRASIL (MDIC). Estatísticas de comércio exterior. Disponível em: http://www.mdic.gov.br/. Acesso em: 26 de fevereiro de 2014.

MOREIRA, M. B. Agriculture and Food in the globalization Age. Journal of International Sociology of Food And Agriculture, vol. 12, 2004, p. 17-28. Disponível em: http://ijsaf.org/contents/12/moreira/index.html. Acesso em: 05 de outubro de 2013.

MOYO, S.; YEROS, P. (Orgs.). Recuperando la tierra: El resurgimiento de los movimientos rurales en África, Asia y América Latina. Buenos Aires: CLACSO, 2008 .

NICKSON, A. Brazilian Colonization of the Eastern Border Region of Paraguay. Journal of Latin American Studies, Vol. 13, No. 1, May, 1981, p. 111-131. 
NIEMEYER, C. B. de. Contestando a governança global: a Rede Transnacional de Movimentos Sociais Via Campesina e suas relações com a FAO e OMC. Rio de Janeiro, 2006. 190p. Dissertação (Mestrado em Relações Internacionais) Instituto de Relações Internacionais, Pontifícia Universidade Católica do Rio de Janeiro.

OSÓRIO, J. Padrão de reprodução do capital: uma proposta teórica. In: FERREIRA, C.; OSORIO, J.; LUCE, M. (Orgs.). Padrão de reprodução do capital: contribuições da teoria marxista da dependência. São Paulo: Boitempo, 2012, p. 37-86.

América Latina: o novo padrão exportador de especialização produtiva - estudo de cinco economias da região. In: FERREIRA, C.; OSORIO, J.; LUCE, M. (Orgs.). Padrão de reprodução do capital: contribuições da teoria marxista da dependência. São Paulo: Boitempo, 2012, p. 103-133.

OTERO, G. The Neoliberal Food Regime in Latin America: state, agribusiness transnational corporations and biotechnology. Canadian Journal of Development Studies, 33 (3), sep. 2012, p. 282-294.

Neoliberal Globalism and the Biotechnology Revolution: Economic and Historical Context. In: (Ed.). Food for the few: Neoliberal Globalism and Biotechnology in Latin America. Austin: University of Texas Press, 2008, p. 1-29.

OTERO, G.; PECHLANER, G. Latin America Agriculture, Food and Biotechnology: Temperate Dietary Pattern Adoption and Unsustainability. In: OTERO, G. (Ed.). Food for the few: Neoliberal Globalism and Biotechnology in Latin America. Austin: University of Texas Press, 2008, p. 31-60.

PALAU, T. Alimentación, agricultura y neoliberalismo en Paraguay. In: ROJAS, L. (org.). La Economía Paraguaya Bajo el Orden Neoliberal. Asunción: BASE IS, SEPPY, RLS, marzo 2011, p. 91-113.

Capitalismo agrario y expulsión campesina: Avance del monocultivo de soja transgénica en el Paraguay. Asunción: Centro de Estudios e Investigaciones de Derecho Rural y Reforma Agraria (CEIDRA); Intermon Oxfam, 2004.

"Políticas" Agrarias en el Paraguay. Instrumentos de la Discriminación. NOVAPOLIS Revista de Estudios Contemporáneos, n. 2, febrero de 2003, p. 3-23.

PALAU, T; HEIKEL, V. Los campesinos, el estado y las empresas en la frontera agrícola. Asunción: BASE ISEC/PISPAL, 1987.

PECHLANER, G. The Sociology of Agriculture in Transition: The Political Economy of Agriculture after Biotechnology. Canadian Journal of Sociology, 35 (2), 2010, p. 243-269.

PIÑEIRO, D. E. En busca de la identidad: La acción colectiva en los conflictos agrarios de América Latina. Buenos Aires: CLACSO, 2004. 
Desafíos e Incertidumbres para la Sociología Agraria en la Transición hacia un nuevo Modelo de Desarrollo. In: PIÑEIRO, D. E. (comp.). Globalización, Integración Regional y Consecuencias Sociales sobre la Agricultura. Montevideo: AUGM/UNESCO/Universidad de la República, 1996, p. 33-80.

PREBISCH, R. El desarrollo económico de la América Latina y algunos de sus principales problemas. Desarrollo Económico, v. 26, n. 103, out./dez. 1986, p. 479-502.

RED DE INVERSIONES Y EXPORTACOINES (REDIEX/MIC). Informaciones sobre las políticas de incentivo a las inversiones y exportaciones en el Paraguay. Disponível em: http://www.rediex.gov.py/. Acesso em: fevereiro de 2014.

REUTERS. Productores paraguayos de soja se niegan a pagar regalías a Monsanto. Reuters América Latina, 25/10/2012. Disponível em: http://lta.reuters.com/article/domesticNews/idLTASIE89O07H20121025?pageNu mber $=1 \&$ virtualBrandChannel=0. Acesso em: 28 abril de 2014.

RIQUELME, M. Notas para el estudio de las causas y efectos de las migraciones brasileñas en el Paraguay. In: FOGEL, R.; RIQUELME, M. (orgs.). Enclave Sojero: Merma de soberanía y Pobreza. Asunción: Centro de Estudios Rurales Interdisciplinarios, 2005, p. 188-156.

ROJAS, L. La tierra en disputa: Extractivismo, exclusión y resistencia. Asunción: BASE IS, febrero de 2014.

(coord.). El Proceso Histórico de la Economía Paraguaya. Asunción: Secretaria Nacional de Cultura (SNC), 2012.

(Org.). La Economía Paraguaya bajo el Orden Neoliberal. Asunción: BASE-IS, SEPPY, RLS, marzo 2011.

IS/DIAKONIA, 2009.

Actores del Agronegocio en Paraguay. Asunción: BASE

ROJAS, L.; FRANCESCHELLI, I. Informe: Tierra, agronegocios y Derechos Humanos en el contexto Cartes (Agosto - Noviembre, 2013). Asunción: BASE IS, dic. 2013.

ROJAS DE CERQUEIRA, G. La Inversión Brasileña Directa en Paraguay: Características, Motivaciones y Perspectivas. Observatorio de Economía Internacional (OBEI) - Centro de Análisis y Difusión de la Economía Paraguaya (CADEP). $\quad 2012 . \quad$ Noviembre Disponível em: http://www.cadep.org.py/uploads/2012/12/articulo-GR-full-color.pdf. Acesso em: 29 de novembro de 2012.

RULLI, J. Introducción al modelo de la soja. In: RULLI, J. (coord.). Repúblicas Unidas de la Soja: realidades sobre la producción de soja en América del Sur. Grupo de Reflexión Rural (GRR), 2007, p. 15-32. Disponível em: www.lasojamata.net. Acesso em: 2 de fevereiro de 2013. 
SANTOS, T. dos. La Teoría de La Dependencia: un balance histórico y teórico. In: LÓPEZ SEGRERA, F. (comp.) Los retos de la globalización: ensayos en homenaje a Theotônio do Santos. Caracas: UNESCO, 1998, p. 93-151.

The structure of Dependence. The American Economic

Review, v. 60, n. 2, May 1970, p. 231-236.

SCHLESINGER, S.; NORONHA, S. O Brasil está nu! O avanço na monocultura da soja, o grão que cresceu demais. Rio de Janeiro: FASE - Federação de Órgãos para Assistência Social e Educacional, novembro de 2006.

SEMINO, S. Perspectivas futuras del Agronegocio de la soja: Biodiesel, el nuevo mercado. In: RULLI, J. (coord.). Repúblicas Unidas de la Soja: realidades sobre la producción de soja en América del Sur. Grupo de Reflexión Rural (GRR), 2007, p. 99-129. Disponível em: www.lasojamata.net. Acesso em: 2 de fevereiro de 2013.

SORJ, B. Estado e classes sociais na agricultura brasileira. Centro Edelstein de pesquisas sociais, 2008. Disponível em: www.bvce.org. Acesso em: 30 de dezembro de 2013.

SOTELO VALENCIA, A. Neo-imperialismo, dependência e novas periferias na economia mundial. In: SADER, E.; SANTOS, T. dos (coords.); MARTINS, C. E.; SOTELO VALENCIA, A. (Orgs.). A América Latina e os desafios da globalização. Ensaios em homenagem a Ruy Mauro Marini. Rio de Janeiro: Ed. PUC-RIO; São Paulo: Boitempo Editorial, 2009, p. 111-133.

SOUCHAUD, S. Geografía de la migración brasileña en Paraguay. Serie Investigación y Desarrollo, Fondo de Población de las Naciones Unidas (UNFPA)/ Asociación Paraguaya de Estudios de Población (ADEPO). Asunción, Julio 2007.

Dinámica de la agricultura de exportación paraguaya y el complejo de la soja: una organización del territorio al estilo brasileño. In: FOGEL, R.; RIQUELME, M. (orgs.). Enclave Sojero: Merma de soberanía y pobreza. Asunción: Centro de Estudios Rurales Inter-disciplinares (CERI), 2005, p. 16-35.

THE GUARDIAN. The Global Food Crisis: ABCD of food - how the multinationals dominate trade. The Guardian, June of 2011. Disponível em: http://www.theguardian.com/global-development/poverty-

matters/2011/jun/02/abcd-food-giants-dominate-trade. Acesso em: 21 de maio de 2014.

ÚLTIMA HORA. Colonos cierran ruta y evitan que el INDERT ingrese a las tierras de Itakyry. Jornal Última Hora, 25/03/2014. Disponível em: http://www.ultimahora.com/colonos-cierran-ruta-y-evitan-que-indert-ingrese-lastierras-itakyry-n777871.html. Acesso em: 29 de março de 2014. [2014a]

Productores piden a multinacionales que respetem la ley y paguen el IVA. Jornal Última Hora, 27/04/2014. Disponível em: 
http://www.ultimahora.com/productores-piden-multinacionales-que-respeten-laley-y-paguen-el-iva-n789719.html. Acesso em: 28 de abril de 2014. [2014b]

UNIÓN DE GREMIOS DE LA PRODUCCIÓN (UGP). Informaciones institucionales sobre la UGP. Disponível em: http://www.ugp.org.py/. Acesso em: março de 2014.

UNITED STATES DEPARTMENT OF AGRICULTURE (USDA). Oilseeds: World Market and Trade, 09 de abril de 2014. Disponível em: http://usda.mannlib.cornell.edu/MannUsda/viewDocumentInfo.do?documentID=1 490. Acesso em: 22 de maio de 2014.

UNITED NATIONS CONFERENCE ON TRADE AND DEVELOPMENT (UNCTAD). World Investment Report 2009: Transnational corporations, agricultural production and development. New York and Geneva: UNCTAD, 2009.

VUYK, C. Subimperialismo brasileño y dependencia del Paraguay: los intereses económicos detrás del golpe de Estado de 2012. Asunción: Cultura y Participación, 2014.

. Subimperialismo brasilero y dependencia paraguaya: análisis de la situación actual. Documento de trabajo. Buenos Aires: CLACSO, 2013. Disponível em: http://biblioteca.clacso.edu.ar/gsdl/collect/clacso/index/assoc/D8967.dir/VuykTra bajoFinalCLACSO2013.pdf. Acesso em: 27 de novembro de 2013.

WAGNER, A. Ruy Mauro Marini: uma interpretação marxista do capitalismo dependente. Revista em Pauta, n. 22, 2009, p. 59-75.

WALLERSTEIN, I. World-Systems Analysis: An Introduction. Durham: Duke University Press, 2004; p. 1-22.

The Rise and Future Demise of the World Capitalist System: Concepts for comparative analysis. Comparative Studies in Society and History, Volume 16, Issue 4, September 1974, p. 387-415.

WILKINSON, J. Globalization of Agribusiness and Developing World Food Systems. Monthly Review, vol. 61, n. 4, sep. 2009. Disponível em: http://monthlyreview.org/2009/09/01/globalization-of-agribusiness-anddeveloping-world-food-systems. Acesso em: 7 de outubro de 2013.

WORLD INTELLECTUAL PROPERTY ORGANIZATION (WIPO). Informações sobre o Sistema Internacional de Patentes. Disponível em: http://www.wipo.int/patents/en/. Acesso em: junho de 2014.

WTOSTAT. Base de dados estatísticos da Organização Mundial do Comércio. Disponível em: http://stat.wto.org/Home/WSDBHome.aspx?Language=. Acesso em: 04 de junho de 2014. 
8.

\section{Anexos}

Figura 13 - As 10 maiores empresas de sementes do mundo (2011)

\begin{tabular}{|c|l|c|c|}
\hline Rango & \multicolumn{1}{|c|}{ Compañía } & $\begin{array}{c}\text { Venta de semillas, } \\
\mathbf{2 0 1 1} \text { (mdd) }\end{array}$ & $\begin{array}{c}\text { Porcentaje } \\
\text { del mercado }\end{array}$ \\
\hline 1. & Monsanto & 8,953 & 26.0 \\
\hline 2. & DuPont Pioneer (EUA) & 6,261 & 18.2 \\
\hline 3. & Syngenta (Suiza) & 3,185 & 9.2 \\
\hline 4. & Vilmorin (Francia) (Groupe Limagrain) & 1,670 & 4.8 \\
\hline 5. & WinField (EUA) (Land O Lakes) & 1,346 (est.) & 3.9 \\
\hline 6. & KWS (Alemania) & 1,226 & 3.6 \\
\hline 7. & Bayer Cropscience (Alemania) & 1,140 & 3.3 \\
\hline 8. & Dow AgroSciences (EUA) & 1,074 & 3.1 \\
\hline 9. & Sakata (Japón) & 548 & 1.6 \\
\hline 10. & Takii \& Company (Japón) & 548 & 1.6 \\
\hline Total de las diez & $\mathbf{2 5 , 9 5 1}$ & 75.3 \\
\hline
\end{tabular}

Fonte: ETC Group (2013:6)

Figura 14 - As 11 maiores empresas agroquímicas do mundo (2011)

\begin{tabular}{|c|l|c|c|}
\hline Rango & \multicolumn{1}{|c|}{ Compañia (sede) } & $\begin{array}{c}\text { Ventas de protección } \\
\text { de cultivos, 2011, } \\
\text { en millones de dólares }\end{array}$ & $\begin{array}{c}\text { Porcentaje del } \\
\text { mercado }\end{array}$ \\
\hline 1. & Syngenta (Suiza) & 10,162 & 23.1 \\
\hline 2. & Bayer CropScience (Alemania) & 7,522 & 17.1 \\
\hline 3. & BASF (Alemania) & 5,393 & 12.3 \\
\hline 4. & Dow AgroSciences (EUA) & 4,241 & 9.6 \\
\hline 5. & Monsanto (EUA) & 3,240 & 7.4 \\
\hline 6. & DuPont (EUA) & 2,900 & 6.6 \\
\hline & $\begin{array}{l}\text { Makhteshim-Agan Industries } \\
\text { (Israel) adquirida por China }\end{array}$ & 2,691 & 6.1 \\
\hline Nacional Agrochemical & Company, Octubre de 2011 & 2,185 & 5.0 \\
\hline 8. & Nufarm (Australia) & 1,738 & 3.9 \\
\hline 9. & Sumitomo Chemical (Japón) & 1,504 & 3.4 \\
\hline 10. & Arysta LifeScience (Japón) & 1,465 & 3.3 \\
\hline 11. & FMC Corporation (EUA) & 41,576 & $94.5 \%$ \\
\hline Total de las primeras 10 & 43,041 & $97.8 \%$ \\
\hline Total de las primeras 11 & & \\
\hline
\end{tabular}

Fonte: ETC Group (2013:10) 
Tabela 15 - Utilização do grão de soja no Paraguai (1989-2013) - Em toneladas

\begin{tabular}{|r|r|r|r|r|r|}
\hline Ano & Exportação & Indústria & $\begin{array}{c}\text { Produção } \\
\text { total }\end{array}$ & $\begin{array}{c}\text { Exp/Prod. } \\
\text { Total }\end{array}$ & $\begin{array}{c}\text { Ind/ } \\
\text { Prod } \\
\text { Total }\end{array}$ \\
\hline $\mathbf{1 9 8 9}$ & 945.375 & 99.741 & 1.070 .116 & $88 \%$ & $9 \%$ \\
\hline $\mathbf{1 9 9 0}$ & 1.559 .897 & 146.738 & 1.741 .635 & $90 \%$ & $8 \%$ \\
\hline $\mathbf{1 9 9 1}$ & 866.525 & 269.141 & 1.170 .666 & $74 \%$ & $23 \%$ \\
\hline $\mathbf{1 9 9 2}$ & 831.885 & 519.895 & 1.376 .780 & $60 \%$ & $38 \%$ \\
\hline $\mathbf{1 9 9 3}$ & 1.390 .259 & 558.682 & 2.008 .941 & $69 \%$ & $28 \%$ \\
\hline $\mathbf{1 9 9 4}$ & 1.174 .761 & 666.748 & 1.891 .509 & $62 \%$ & $35 \%$ \\
\hline $\mathbf{1 9 9 5}$ & 1.537 .603 & 720.000 & 2.307 .603 & $67 \%$ & $31 \%$ \\
\hline $\mathbf{1 9 9 6}$ & 1.587 .428 & 741.000 & 2.408 .428 & $66 \%$ & $31 \%$ \\
\hline $\mathbf{1 9 9 7}$ & 2.150 .000 & 541.000 & 2.771 .000 & $78 \%$ & $20 \%$ \\
\hline $\mathbf{1 9 9 8}$ & 2.293 .601 & 641.000 & 2.988 .201 & $77 \%$ & $21 \%$ \\
\hline $\mathbf{1 9 9 9}$ & 2.298 .758 & 596.000 & 2.980 .058 & $77 \%$ & $20 \%$ \\
\hline $\mathbf{2 0 0 0}$ & 2.025 .552 & 800.871 & 2.911 .423 & $70 \%$ & $28 \%$ \\
\hline $\mathbf{2 0 0 1}$ & 2.509 .948 & 917.231 & 3.502 .179 & $72 \%$ & $26 \%$ \\
\hline $\mathbf{2 0 0 2}$ & 2.385 .979 & 1.085 .695 & 3.546 .674 & $67 \%$ & $31 \%$ \\
\hline $\mathbf{2 0 0 3}$ & 3.167 .193 & 1.260 .822 & 4.518 .015 & $70 \%$ & $28 \%$ \\
\hline $\mathbf{2 0 0 4}$ & 2.664 .415 & 1.172 .000 & 3.911 .415 & $68 \%$ & $30 \%$ \\
\hline $\mathbf{2 0 0 5}$ & 2.882 .182 & 1.077 .646 & 4.040 .828 & $71 \%$ & $27 \%$ \\
\hline $\mathbf{2 0 0 6}$ & 2.380 .344 & 1.180 .842 & 3.641 .186 & $65 \%$ & $32 \%$ \\
\hline $\mathbf{2 0 0 7}$ & 4.136 .117 & 1.305 .000 & 5.581 .117 & $74 \%$ & $23 \%$ \\
\hline $\mathbf{2 0 0 8}$ & 4.438 .085 & 1.390 .000 & 5.968 .085 & $74 \%$ & $23 \%$ \\
\hline $\mathbf{2 0 0 9}$ & 2.282 .705 & 1.224 .500 & 3.647 .205 & $63 \%$ & $34 \%$ \\
\hline $\mathbf{2 0 1 0}$ & 4.654 .429 & 1.558 .000 & 6.462 .429 & $72 \%$ & $24 \%$ \\
\hline $\mathbf{2 0 1 1}$ & 5.138 .364 & 1.570 .000 & 7.128 .364 & $72 \%$ & $22 \%$ \\
\hline $\mathbf{2 0 1 2}$ & 2.971 .039 & 772.000 & 4.043 .039 & $73 \%$ & $19 \%$ \\
\hline $\mathbf{2 0 1 3}$ & 4.932 .448 & 3.069 .742 & 8.202 .190 & $60 \%$ & $\mathbf{3 7 \%}$ \\
\hline & MÉDIA (1989-2013) & & $\mathbf{7 1 \%}$ & $\mathbf{2 6 \%}$ \\
\hline & & & & & \\
\hline
\end{tabular}

Fonte: Elaboração própria com base em dados da CAPECO (2014) 
Tabela 16 - Produção e exportação de máquinas agrícolas no Brasil (2000-2012) - Em unidades

\begin{tabular}{|c|c|c|c|c|c|c|c|c|c|c|c|c|c|}
\hline & 2000 & 2001 & 2002 & 2003 & 2004 & 2005 & 2006 & 2007 & 2008 & 2009 & 2010 & 2011 & 2012 \\
\hline Total produzido (a) & 35.501 & 44.339 & 52.010 & 61.026 & 69.418 & 52.871 & 46.065 & 65.003 & 84.992 & 66.210 & 88.874 & 81.513 & 83.704 \\
\hline Total exportado (b) & 5.270 & 8.246 & 10.443 & 21.422 & 31.022 & 30.678 & 22.437 & 27.248 & 30.280 & 14.780 & 19.176 & 18.334 & 16.915 \\
\hline$\%(b / a)$ & $14,8 \%$ & $18,6 \%$ & $20,1 \%$ & $35,1 \%$ & $44,7 \%$ & $58,0 \%$ & $48,7 \%$ & $41,9 \%$ & $35,6 \%$ & $22,3 \%$ & $21,6 \%$ & $22,5 \%$ & $20,2 \%$ \\
\hline Média prod. & \multicolumn{3}{|c|}{43.950} & \multicolumn{7}{|c|}{-} & \multicolumn{3}{|c|}{84.697} \\
\hline
\end{tabular}

Fonte: Elaboração própria com base em ANFAVEA (2013:134;139)

Tabela 17 - Balança comercial brasileira de máquinas agrícolas (2001-2012) - US\$ milhões

\begin{tabular}{|c|c|c|c|c|c|c|c|c|c|c|c|c|}
\hline & 2001 & 2002 & 2003 & 2004 & 2005 & 2006 & 2007 & 2008 & 2009 & 2010 & 2011 & 2012 \\
\hline Exportações & 167,2 & 263,8 & 502,2 & 810,7 & 827 & 701,7 & 1018,2 & 1369,6 & 654,2 & 948,7 & 1048,5 & 906 \\
\hline Importações & 30,7 & 12,1 & 13,5 & 65,2 & 38 & 35 & 103,1 & 195,6 & 136,3 & 177,9 & 280,8 & 483,8 \\
\hline Saldo & 136,5 & 251,7 & 488,7 & 745,5 & 789 & 666,7 & 915,1 & 1174 & 517,9 & 770,8 & 767,7 & 422,2 \\
\hline Média Exp. & \multicolumn{3}{|c|}{311,1} & \multicolumn{6}{|c|}{ - } & \multicolumn{3}{|c|}{967,7} \\
\hline
\end{tabular}

Fonte: Elaboração própria com base em ANFAVEA (2013:48) 
Figura 15 - Os latifúndios na fronteira paraguaia por volta de 1950

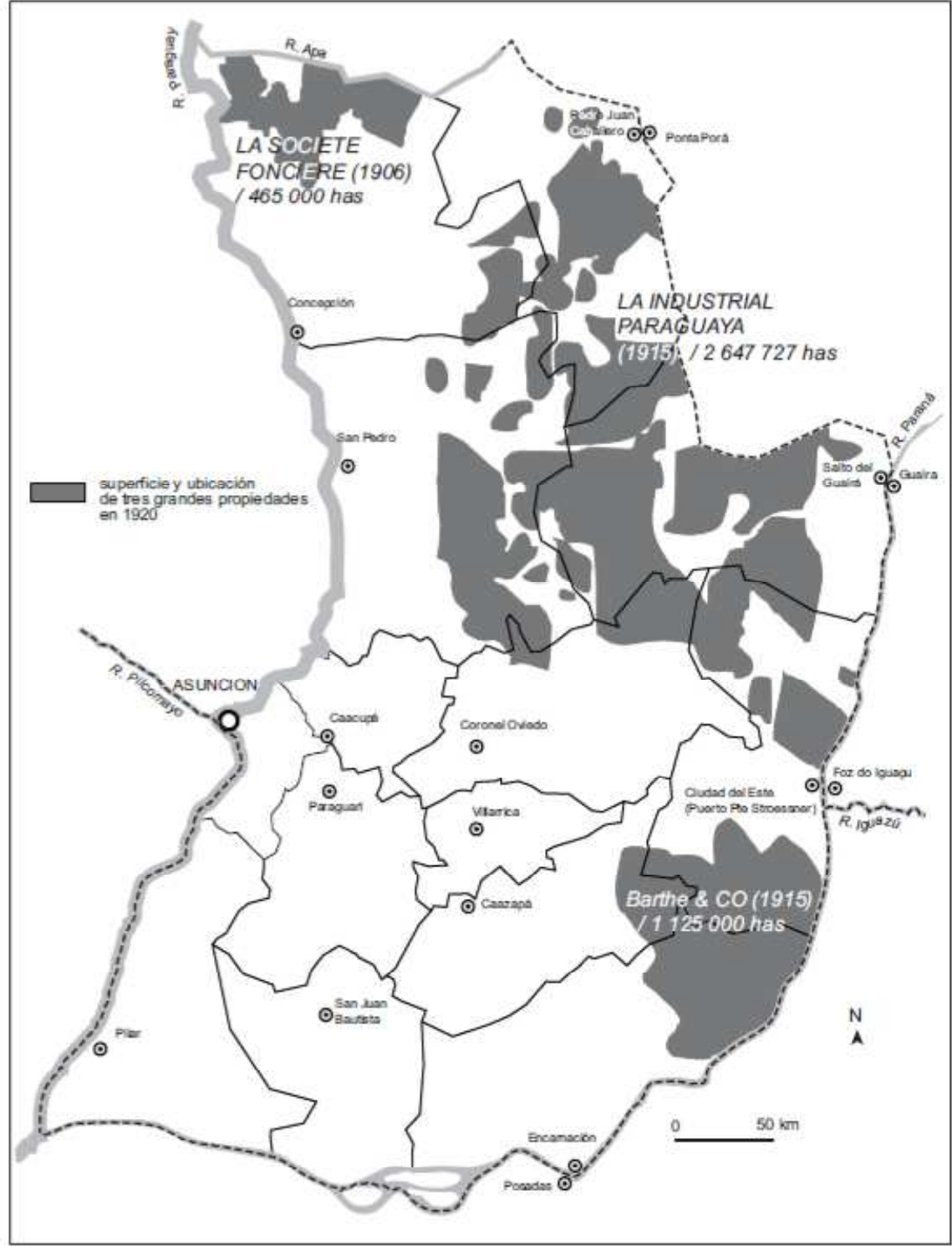

Fonte: Souchaud (2007:74) 
Tabela 18 - Evolução do intercâmbio comercial de bens entre Paraguai e Brasil (1990-2012) - Em Milhares de US\$/FOB

\begin{tabular}{|c|c|c|c|c|c|c|c|c|c|c|c|}
\hline & 1990 & 1991 & 1992 & 1993 & 1994 & 1995 & 1996 & 1997 & 1998 & 1999 & 2000 \\
\hline $\begin{array}{l}\text { Exportações totais } \\
\text { (ET) }\end{array}$ & 958.681 & 737.096 & 656.555 & 725.218 & 1.843 .219 & 2.019 .209 & 2.181 .969 & 2.402 .006 & 2.277 .692 & 2.013 .013 & 2.200 .088 \\
\hline $\begin{array}{l}\text { Exportações totais } \\
\text { para Brasil (EB) }\end{array}$ & 312.303 & 203.082 & 171.447 & 215.123 & 1.339 .595 & 1.426 .036 & 1.522 .224 & 1.511 .186 & 1.427 .531 & 1.312 .950 & 1.421 .895 \\
\hline$\%(\mathrm{~EB} / \mathrm{ET})$ & $32,6 \%$ & $27,6 \%$ & $26,1 \%$ & $29,7 \%$ & $72,7 \%$ & $70,6 \%$ & $69,8 \%$ & $62,9 \%$ & $62,7 \%$ & $65,2 \%$ & $64,6 \%$ \\
\hline $\begin{array}{l}\text { Importações totais } \\
\text { (IT) }\end{array}$ & 1.193 .365 & 1.275 .387 & 1.237 .148 & 1.477 .540 & 2.140 .436 & 2.782 .163 & 2.850 .477 & 3.099 .240 & 2.470 .783 & 1.725 .046 & 2.050 .383 \\
\hline $\begin{array}{l}\text { Importações totais } \\
\text { para Brasil (IB) }\end{array}$ & 207.292 & 234.256 & 263.243 & 340.412 & 555.050 & 644.835 & 933.114 & 961.459 & 822.353 & 509.620 & 502.072 \\
\hline$\%(\mathrm{IB} / \mathrm{IT})$ & $17,4 \%$ & $18,4 \%$ & $21,3 \%$ & $23,0 \%$ & $25,9 \%$ & $23,2 \%$ & $32,7 \%$ & $31,0 \%$ & $33,3 \%$ & $29,5 \%$ & $24,5 \%$ \\
\hline
\end{tabular}

\begin{tabular}{|c|c|c|c|c|c|c|c|c|c|c|c|c|}
\hline & 2001 & 2002 & 2003 & 2004 & 2005 & 2006 & 2007 & 2008 & 2009 & 2010 & 2011 & 2012 \\
\hline $\begin{array}{l}\text { Exportações totais } \\
\text { (ET) }\end{array}$ & 2.356 .519 & 2.328 .800 & 2.584 .532 & 2.874 .456 & 3.152 .568 & 3.472 .365 & 4.723 .587 & 6.407 .112 & 5.079 .610 & 6.516 .556 & 7.776 .435 & 7.283 .874 \\
\hline $\begin{array}{l}\text { Exportações totais } \\
\text { para Brasil (EB) }\end{array}$ & 1.405 .926 & 1.487 .598 & 1.470 .596 & 1.359 .430 & 1.540 .255 & 1.650 .066 & 2.072 .326 & 2.184 .915 & 2.238 .117 & 2.194 .778 & 2.500 .098 & 2.850 .332 \\
\hline$\%($ EB/ET $)$ & $59,7 \%$ & $63,9 \%$ & $56,9 \%$ & $47,3 \%$ & $48,9 \%$ & $47,5 \%$ & $43,9 \%$ & $34,1 \%$ & $44,1 \%$ & $33,7 \%$ & $32,1 \%$ & $39,1 \%$ \\
\hline $\begin{array}{l}\text { Importações totais } \\
\text { (IT) }\end{array}$ & 1.988 .809 & 1.510 .241 & 1.771 .641 & 2.466 .049 & 3.058 .032 & 4.517 .794 & 5.551 .974 & 8.532 .087 & 6.516 .640 & 9.393 .216 & 11.548 .963 & 10.756 .391 \\
\hline $\begin{array}{l}\text { Importações totais } \\
\text { para Brasil (IB) }\end{array}$ & 563.588 & 477.582 & 617.317 & 800.481 & 845.079 & 967.957 & 1.611 .562 & 2.317 .599 & 1.527 .441 & 2.280 .658 & 3.072 .350 & 2.550 .594 \\
\hline$\%(\mathrm{IB} / \mathrm{IT})$ & $28,3 \%$ & $31,6 \%$ & $34,8 \%$ & $32,5 \%$ & $27,6 \%$ & $21,4 \%$ & $29,0 \%$ & $27,2 \%$ & $23,4 \%$ & $24,3 \%$ & $26,6 \%$ & $23,7 \%$ \\
\hline
\end{tabular}

Fonte: Elaboração própria com base em dados do Banco Central do Paraguai (BCP, 2014a) 
Tabela 19 - Fluxos de IED no Paraguai por atividade (2003-2012) e estoque de IED por atividade (2012)

\begin{tabular}{|c|c|c|c|c|c|c|c|c|c|c|c|c|c|}
\hline \multicolumn{11}{|c|}{ FLUXOS DE IED POR ATIVIDADE - (2003-2012) } & \multicolumn{3}{|c|}{$\begin{array}{l}\text { ESTOQUE DE IED NO } 4^{\circ} \\
\text { TRIMESTRE DE } 2012\end{array}$} \\
\hline $\begin{array}{ll}\text { Classificação } & \\
\text { Nacional } & \text { de } \\
\text { Atividades } & \text { do } \\
\text { Paraguai (CNAP) } & \end{array}$ & 2003 & 2004 & 2005 & 2006 & 2007 & 2008 & 2009 & 2010 & 2011 & 2012 & $\begin{array}{c}\text { Estoque } \\
\text { total de IED } \\
\text { por } \\
\text { atividade }\end{array}$ & $\begin{array}{c}(\%) \text { de } \\
\text { cada } \\
\text { atividade } \\
\text { no estoque } \\
\text { total }\end{array}$ & $\begin{array}{l}\text { Total } \\
\text { acumulado } \\
\text { por setor }\end{array}$ \\
\hline Agricultura & -5.404 & 18.394 & -1.529 & -35.714 & 1 & 6.209 & 9.689 & -5.847 & 977 & 564 & 139.958 & $2,9 \%$ & Primário \\
\hline Pecuária & 0 & 0 & 0 & 0 & 0 & 0 & 0 & 0 & 0 & 0 & $\mathbf{0}$ & $0,0 \%$ & \multirow{4}{*}{$\begin{array}{c}206.437 \\
(4,3 \%)\end{array}$} \\
\hline Florestal & 222 & -1.006 & -130 & 141 & -2.179 & -3.289 & -1.284 & 12 & 12.638 & 1.737 & 66.479 & $1,4 \%$ & \\
\hline Pesca & 0 & 0 & 0 & 0 & 0 & 0 & 0 & 0 & 0 & 0 & $\mathbf{0}$ & $0,0 \%$ & \\
\hline Mineria & 0 & 0 & 0 & 0 & 0 & 0 & 0 & 0 & 0 & 0 & $\mathbf{0}$ & $0,0 \%$ & \\
\hline Produção de carne & 36 & 20 & 191 & -33 & 15 & 4 & 107 & 0 & 1.782 & -135 & 46.389 & $1,0 \%$ & \multirow[t]{7}{*}{ Secundário } \\
\hline Elaboração de óleos & 30.306 & -10.064 & -3.684 & 105.180 & -72.828 & 56.080 & -78.059 & 95.210 & -5.451 & 259.697 & 688.608 & $14,3 \%$ & \\
\hline Produção de lácteos & -236 & -801 & 117 & 8.109 & -835 & -970 & 60 & 169 & 858 & -584 & 5.102 & $0,1 \%$ & \\
\hline Moenda e padaria & -317 & 256 & 15 & -598 & 270 & -1.217 & -465 & 1.311 & 0 & 0 & 7.162 & $0,1 \%$ & \\
\hline Açúcar & 0 & 0 & 0 & 0 & 0 & 0 & 0 & 0 & 0 & 0 & $\mathbf{0}$ & $0,0 \%$ & \\
\hline Outros alimentos & 2.203 & 578 & 517 & 4.232 & 1.997 & -1.819 & -17.777 & -10.635 & 0 & 0 & 6.360 & $0,1 \%$ & \\
\hline Bebidas e tabaco & -18.284 & 9.386 & -21.346 & -58.876 & 56.046 & 34.449 & 27.754 & -14.103 & 74.259 & 14.749 & 370.425 & $7,7 \%$ & \\
\hline $\begin{array}{l}\text { Têxteis e prendas de } \\
\text { vestir }\end{array}$ & 0 & -6.793 & 80 & -6.651 & -12 & 6.862 & -94 & 394 & 351 & 240 & 11.182 & $0,2 \%$ & \multirow[t]{5}{*}{$\begin{array}{c}1.457 .467 \\
(30,3 \%)\end{array}$} \\
\hline Couro e calçados & 1.878 & 1.585 & 3.572 & 543 & -1.299 & -2.912 & 1.296 & -3.984 & 2.402 & 2.244 & 25.461 & $0,5 \%$ & \\
\hline Indústria da maderia & 185 & -317 & 656 & -460 & 18 & 43 & -1.294 & -332 & -3.206 & 297 & 6.342 & $0,1 \%$ & \\
\hline $\begin{array}{l}\text { Papel e produtos do } \\
\text { papel }\end{array}$ & 979 & 739 & 407 & -332 & -2.686 & 926 & 1.659 & 111 & -646 & 423 & 17.398 & $0,4 \%$ & \\
\hline Refino de petróleo & 0 & 0 & 0 & 0 & 0 & 0 & 0 & 0 & 0 & 0 & $\mathbf{0}$ & $0,0 \%$ & \\
\hline
\end{tabular}




\begin{tabular}{|c|c|c|c|c|c|c|c|c|c|c|c|c|c|}
\hline Produtos químicos & 3.402 & -4.277 & 1.571 & 13.318 & 22.958 & 54.733 & -44.503 & -9.691 & -8.727 & 39.629 & 183.544 & $3,8 \%$ & \\
\hline $\begin{array}{lr}\text { Fabricação } & \text { de } \\
\text { produtos } & \text { não } \\
\text { metálicos } & \end{array}$ & 351 & 715 & -586 & -1.635 & -2.658 & 1.577 & 95 & -10.741 & 5.295 & 12.547 & 80.947 & $1,7 \%$ & \\
\hline $\begin{array}{l}\text { Fabricação de metais } \\
\text { comuns }\end{array}$ & 0 & 0 & 0 & 0 & 0 & 0 & 0 & 0 & 0 & 0 & $\mathbf{0}$ & $0,0 \%$ & \\
\hline $\begin{array}{l}\text { Fabricação de } \\
\text { máquinas e equipos }\end{array}$ & 1.286 & 1.815 & 2.701 & -2.309 & 6.555 & 2.031 & 1.968 & 5.066 & 0 & 0 & 5.759 & $0,1 \%$ & \\
\hline $\begin{array}{l}\text { Outros produtos } \\
\text { manufaturados }\end{array}$ & 0 & 0 & 0 & 0 & 0 & -503 & 0 & 0 & 0 & 0 & $\mathbf{0}$ & $0,0 \%$ & \\
\hline Eletricidade e água & 0 & 0 & 0 & 0 & 0 & 0 & -220 & 0 & 0 & 0 & $\mathbf{0}$ & $0,0 \%$ & \\
\hline Construção & 258 & -215 & -97 & 273 & 614 & -520 & -1.494 & -309 & -16 & 9 & 2.788 & $0,1 \%$ & \\
\hline Comércio & 55.195 & -5.381 & 24.258 & 5.094 & 41.262 & 10.045 & 89.011 & 88.111 & 178.430 & -16.746 & 991.452 & $20,6 \%$ & \multirow[t]{9}{*}{ Terciário } \\
\hline Transportes & -8.244 & -7.614 & -850 & -32.739 & 106.248 & 6.705 & 40.165 & 40.188 & 117.141 & -88.542 & 410.120 & $8,5 \%$ & \\
\hline Comunicações & 8.602 & -8.627 & 34.360 & 48.856 & -6.407 & -62.862 & 27.953 & -63.743 & 92.345 & 122.943 & 650.066 & $13,5 \%$ & \\
\hline $\begin{array}{l}\text { Intermediação } \\
\text { financeria }\end{array}$ & -29.728 & 40.250 & 17.935 & 48.144 & 59.956 & 109.475 & 42.256 & 106.921 & 91.827 & 175.311 & 1.088 .171 & $22,6 \%$ & \\
\hline Aluguel de moradias & 62 & -2.547 & 0 & 0 & 0 & 0 & 0 & 0 & 0 & 0 & $\mathbf{0}$ & $0,0 \%$ & \\
\hline Serviços a empresas & -130 & -178 & 110 & -173 & -207 & -1.028 & 700 & -384 & 437 & -53 & 2.197 & $0,0 \%$ & \\
\hline Restaurantes e hotéis & -17.567 & 1.843 & -22.800 & 619 & -5.079 & -5.871 & -1.175 & -899 & 0 & -4.559 & 11.695 & $0,2 \%$ & \\
\hline $\begin{array}{l}\text { Serviços a residências } \\
\text { familiares }\end{array}$ & 0 & 0 & 0 & 0 & 0 & 380 & -1.756 & -959 & -3.890 & -2.190 & $\mathbf{0}$ & $0,0 \%$ & \\
\hline $\begin{array}{l}\text { Serviços } \\
\text { governamentais }\end{array}$ & 0 & 0 & 0 & 0 & 0 & 0 & 0 & 0 & 0 & 0 & $\mathbf{0}$ & $0,0 \%$ & \\
\hline $\begin{array}{c}\text { TOTAL DE } \\
\text { FLUXOS DE IED }\end{array}$ & 25.055 & 27.757 & 35.468 & 94.988 & 201.750 & 208.528 & 94.593 & 215.868 & 556.805 & 517.581 & 4.817.605 & $100,0 \%$ & 4.817.605 \\
\hline
\end{tabular}


Tabela 20 - Estoque acumulado de IED (2012) nas atividades agrícolas e agroindustriais no Paraguai - Em Miles de US\$

\begin{tabular}{|c|c|c|c|}
\hline $\begin{array}{ll}\text { Classificação } & \\
\text { Nacional } & \text { de } \\
\text { Atividades } & \text { do } \\
\text { Paraguai (CNAP) }\end{array}$ & $\begin{array}{l}\text { Estoque de } \\
\text { IED por } \\
\text { atividade }\end{array}$ & $\begin{array}{c}(\%) \text { por } \\
\text { atividade } \\
\text { no } \\
\text { estoque } \\
\text { total } \\
\end{array}$ & $\begin{array}{c}\text { Total } \\
\text { acumulado } \\
\text { do setor } \\
\text { agro- } \\
\text { alimentar } \\
\end{array}$ \\
\hline Agricultura & 139.958 & $2,9 \%$ & \multirow{4}{*}{$\begin{array}{c}\text { Atividades } \\
\text { primárias } \\
\mathbf{2 0 6 . 4 3 7} \\
(\mathbf{4 , 3 \% )}\end{array}$} \\
\hline Pecuária & 0 & $0,0 \%$ & \\
\hline Florestal & 66.479 & $1,4 \%$ & \\
\hline Pesca & 0 & $0,0 \%$ & \\
\hline Produção de carne & 46.389 & $1,0 \%$ & \multirow{7}{*}{$\begin{array}{c}\begin{array}{c}\text { Agro } \\
\text { indústria }\end{array} \\
\text { 1.124.046 } \\
(23.3 \%)\end{array}$} \\
\hline Elaboração de óleos & 688.608 & $14,3 \%$ & \\
\hline Produção de lácteos & 5.102 & $0,1 \%$ & \\
\hline Moenda e padaria & 7.162 & $0,1 \%$ & \\
\hline Açúcar & 0 & $0,0 \%$ & \\
\hline Outros alimentos & 6.360 & $0,1 \%$ & \\
\hline Bebidas e tabaco & 370.425 & $7,7 \%$ & \\
\hline $\begin{array}{l}\text { JED TOTAL } \\
\text { acumulado no país }\end{array}$ & 4.817.605 & $100 \%$ & $27,6 \%$ \\
\hline
\end{tabular}

Fonte: Elaboração própria com base em dados do BCP (2014b) 
Tabela 21 - Corporações transnacionais do agronegócio instaladas no Paraguai - 2013

\begin{tabular}{|c|c|c|}
\hline Empresa / País de Origem & $\begin{array}{l}\text { Principais } \\
\text { segmentos de } \\
\text { atuação }\end{array}$ & Descrição geral da empresa \\
\hline $\begin{array}{c}\text { ADM Paraguay S.A.E.C.A. - } \\
\text { EUA (a) }\end{array}$ & $\begin{array}{l}\text { Fornecimento } \\
\text { de insumos; } \\
\text { coleta e } \\
\text { comercialização; } \\
\text { industrialização }\end{array}$ & $\begin{array}{l}\text { A ADM Paraguay é filial da transnacional estadunidense Archer Daniels Midland Company. Instalou-se no Paraguai em } 1997 \text {. A } \\
\text { empresa se dedica ao fornecimento de insumos agrícolas (sementes, fertilizantes, agroquímicos), à coleta, transporte e exportação de } \\
\text { grãos (soja, milho e trigo). Possui uma ampla rede logística no país - com } 30 \text { silos, um porto próprio (e um de aluguel), } 13 \text { navios } \\
\text { rebocadores e } 230 \text { barcaças, sendo responsável pelo processamento de } 30 \% \text { da produção de grãos e sementes oleaginosas. Em } 2013 \text {, a } \\
\text { empresa inaugurou uma nova planta industrial para processamento de grãos de soja, para a elaboração de ração animal e óleo vegetal. É } \\
\text { associada à CAPPRO. }\end{array}$ \\
\hline $\begin{array}{c}\text { Agritrade Paraguay - EUA } \\
\text { (b) }\end{array}$ & $\begin{array}{c}\text { Coleta e } \\
\text { comercialização }\end{array}$ & $\begin{array}{l}\text { A Agritrade Paraguay faz parte da empresa estadunidense de comercialização de matérias primas agrícolas Agri Commodity Trade } \\
\text { LLC. Em nível global, a empresa trabalha com grãos e oleaginosas (milho, soja, trigo, arroz e cevada); azeites e gorduras, e alimentos } \\
\text { balanceados para animais. No Paraguai se dedica principalmente à coleta e comercialização de grãos. É associada à CAPECO. }\end{array}$ \\
\hline $\begin{array}{c}\text { Bayer S. A. / Bayer } \\
\text { CropScience - ALEMANHA } \\
\text { (c) }\end{array}$ & $\begin{array}{l}\text { Fornecimento } \\
\text { de insumos }\end{array}$ & $\begin{array}{l}\text { A Bayer S.A. é filial da multinacional alemã Bayer, que atua em três linhas de negócios: no setor de saúde, elaborando produtos } \\
\text { farmacêuticos (Bayer Health Care); no setor de ciências agrícolas ("Bayer CropScience"); e em materiais inovadores (Bayer Material } \\
\text { Science). No âmbito da agricultura, a empresa se destaca na elaboração de suas marcas próprias de agroquímicos, para a proteção dos } \\
\text { cultivos. No Paraguai, esse braço da Bayer opera importando e comercializando suas marcas (que também são comercializados por } \\
\text { outras empresas locais). }\end{array}$ \\
\hline $\begin{array}{l}\text { Bunge Paraguay S.A. - EUA } \\
\text { (d) }\end{array}$ & $\begin{array}{l}\text { Fornecimento } \\
\text { de insumos; } \\
\text { coleta e } \\
\text { comercialização; } \\
\text { industrialização }\end{array}$ & $\begin{array}{l}\text { A Bunge Paraguay é subsidiária da Bunge Limited, multinacional de origem estadunidense. Instalou-se no Paraguai em 2006, motivado } \\
\text { pela "expansão da fronteira agrícola e a potencialidade do país" - mas já operava de forma indireta há mais de } 30 \text { anos. Dedica-se à } \\
\text { distribuição de fertilizantes, à recepção, armazenagem e comercialização de grãos, e à industrialização de oleaginosas. Junto com a } \\
\text { LDC, formou o consórcio que impulsionou a construção do "Complejo Agroindustrial Angostura (CAIASA)", atualmente, a maior } \\
\text { processadora de grãos e cereais no país. É associada à CAPPRO. }\end{array}$ \\
\hline $\begin{array}{l}\text { Cargill Agropecuaria } \\
\text { S.A.C.I. - EUA (e) }\end{array}$ & $\begin{array}{l}\text { Fornecimento } \\
\text { de insumos; } \\
\text { coleta e } \\
\text { comercialização; } \\
\text { industrialização }\end{array}$ & $\begin{array}{l}\text { A Cargill é uma empresa multinacional privada, com matriz nos Estados Unidos, dedicada à produção e comercialização de produtos e } \\
\text { serviços alimentícios, agrícolas e financeiros. A empresa começou suas atividades no Paraguai em 1978, sendo atualmente uma das } \\
\text { principais empresas agroexportadoras. No país, dedica-se à coleta, processamento e comercialização de sementes oleaginosas e cereais; } \\
\text { à comercialização de insumos agrícolas, e ao fornecimento de serviços vinculados a essas atividades. Conta com uma importante } \\
\text { infraestrutura: um escritório central, e uma planta industrial em Minga Guazú (Alto Paraná), } 38 \text { unidades de recepção, processamento, } \\
\text { armazenagem, e comercialização de grãos, e dois portos (um próprio e outro em sociedade), além de uma ampla frota própria de } \\
\text { rebocadores e barcaças. É associada à CAPPRO. }\end{array}$ \\
\hline $\begin{array}{c}\text { CHS del Paraguay S.R.L - } \\
\text { EUA (f) }\end{array}$ & $\begin{array}{l}\text { Fornecimento } \\
\text { de insumos; } \\
\text { coleta e } \\
\text { comercialização }\end{array}$ & $\begin{array}{l}\text { A CHS del Paraguay é uma empresa vinculada à multinacional estadunidense CHS Inc. de negócios agrícolas, instalada no país } \\
\text { recentemente. Por meio de suas unidades, espalhadas em várias regiões do mundo, a empresa promove a comercialização internacional } \\
\text { de commodities e produtos derivados, assim como o fornecimento de serviços financeiros. Na América do Sul, possui escritórios e } \\
\text { operações no Brasil, Argentina e Paraguay, dedicando-se ao fornecimento de fertilizantes para a produção, e promovendo a exportação } \\
\text { de grâos. É associada à CAPECO. }\end{array}$ \\
\hline
\end{tabular}


Complejo Agroindustrial Angostura S.A. (CAIASA) (g)

\begin{tabular}{|c|} 
(g) \\
ContiParaguay S.A. - \\
HOLANDA/BÉLGICA/EUA
\end{tabular}

(h)

Coleta e mercialização industrialização

\begin{tabular}{|c|c|} 
(h) & industrialização \\
\hline $\begin{array}{c}\text { Dow Agrosciences Paraguay } \\
\text { - EUA (i) }\end{array}$ & $\begin{array}{c}\text { Fornecimento } \\
\text { de insumos }\end{array}$ \\
\hline $\begin{array}{c}\text { JBS Paraguay - BRASIL (J) } \\
\text { Louis Dreyfus Commodities } \\
\text { (LDC) Paraguay S.A. - } \\
\text { FRANÇA (k) }\end{array}$ & $\begin{array}{c}\text { Forneta e } \\
\text { industrializaçãon } \\
\text { de insumos; } \\
\text { coleta e } \\
\text { comercialização; } \\
\text { industrialização }\end{array}$ \\
\hline $\begin{array}{c}\text { Mosanto Paraguay S. A. - } \\
\text { EUA (L) }\end{array}$ & $\begin{array}{c}\text { Fornecimento } \\
\text { de insumos }\end{array}$ \\
\hline
\end{tabular}

Coleta e comercialização industrialização
O complexo foi construído no Paraguai a partir de uma iniciativa conjunta das empresas BUNGE e LDC Paraguai - que contou também com um empréstimo do BID. Foi inaugurado em 2013. A sua capacidade de processamento de grãos é em torno de $20 \%$ de toda a soja produzida no país.

É filial do grupo "Continental Grain Company", que se instalou no país em 1978, por meio da compra de uma empresa local. Atualmente, ContiParaguay se dedica a: o processamento de sementes oleaginosas; produção e comercialização de proteínas e azeites vegetais, tanto para o mercado local como para o internacional, refinamento de azeites comestíveis, margarinas, e outros produtos de uso massivo (como detergentes). "Anualmente procesamos alrededor de 250.000 toneladas métricas de soja grano, semilla de algodón, girasol y canola. Vendemos tanto en el mercado local, como de exportación, más de 120.000 toneladas métricas de harinas y pellets; y más de 50.000 toneladas métricas de aceites vegetales. Nuestro programa de originación contempla básicamente la compra de materias primas necesarias para el programa industrial para lo cual se está inyectando anualmente en torno de US\$ 60.000 .000 en el campo. Nuestra venta de harina de soja de alta proteína son $90 \%$ exportaciones y $10 \%$ ventas locales, en cuanto al pellet de girasol la participación del mercado local es mayor. En el caso de ventas de aceites vegetales, aproximadamente $50 \%$ son de exportación y $50 \%$ de ventas locales". A firma é associada à CAPECO e à CAPPRO.

Dow Agrosciences Paraguay é subsidiária da multinacional estadunidense Dow Agrosciences, empresa líder global na elaboração e fornecimento de agroquímicos para a proteção dos cultivos e controle de pragas, e também na área de biotecnologia (especialmente, no desenvolvimento de sementes geneticamente modificadas). No Paraguai, opera importando e comercializando seus produtos, associando-se a outras empresas para a distribuição dos mesmos em diversos departamentos do país - por meio dos quais oferece também serviços de assistência técnica.

A JBS é uma empresa líder mundial no processamento de carnes bovina, ovina e de aves. Além da área de alimentos, atua nas áreas de couro, biodiesel, colágeno, embalagens metálicas e produtos de limpeza. É atualmente a maior exportadora do mundo de proteína animal. No Paraguai possui duas plantas industriais: uma foi adquirida em 2005 (a Indústria Paraguaya Frigorífica S.A. - IPFSA) e a outra em 2009 (o Frigorífico San Antonio).

A Louis Dreyfus Commodities é uma empresa transnacional de origem francesa, que atua no comércio global de commodities agrícolas. Instalou a sua primeira filial no Paraguai em 2004, dedicando-se, no início, à coleta e exportação de fibras de algodão. Atualmente, as suas principais atividades no país são a coleta, processamento e exportação de oleaginosas e cereais (soja, milho trigo, farinha de soja, óleo vegetal, e em menor escala, algodão e girassol). Conta com duas plantas de processamento e quatro unidades de armazenamento. Junto com a Bunge, formou o consórcio que impulsionou a construção da CAIASA. É associada à CAPPRO.

A Monsanto é uma multinacional de origem estadunidense líder na elaboração de produtos e insumos para a agricultura (principalmente sementes e agroquímicos), sendo líder na área de biotecnologia. A princípio, a empresa ofertava seus produtos e serviços no Paraguai por meio de empresas locais associadas. Em 2010, inaugurou seu escritório oficial em Assunção, e continuou atuando por meio de empresas associadas. Além de suas sedes oficiais no país, a empresa opera por meio de Centros de Serviços - que fornecem suas marcas e serviços técnicos - localizados dentro de outras empresas como: ADM; Agrofértil; AKTRA; Dekalpar S.A.; LAR S.R.L; etc. Em fevereiro de 2011, inaugurou a primeira Estação Experimental na localidade de Santa Rita (Alto Paraná) - no prédio da empresa Dekalpar - que se constitui na base de operações de Breeding (recepção e tratamento de sementes híbridas a serem ensaiadas no país). 


\begin{tabular}{|c|c|c|}
\hline $\begin{array}{c}\text { Nestlé Paraguay S.A. - } \\
\text { SUÍÇA (m) }\end{array}$ & $\begin{array}{c}\text { Industrialização } \\
(* *)\end{array}$ & $\begin{array}{l}\text { A Nestlé é uma empresa líder mundial no segmento de alimentos e bebidas. A Nestlé está presente no Paraguai desde } 1964 \text {, quando } \\
\text { nomeou à empresa "Imexpaco del Paraguay S.R.L" como seu representante exclusivo. Em 1998, estabeleceu-se definitivamente no país, } \\
\text { adquirindo a totalidade do pacote acionário. De acordo com Rojas (2009), a filial paraguaia da Nestlé, importa suas marcas de } \\
\text { alimentos, que são elaborados em outros países (principalmente no Brasil). Assim, embora a empresas esteja voltada à atividade de } \\
\text { industrialização de alimentos, no Paraguai, ela atua importando e comercializando produtos já industrializados }(* *) \text {. }\end{array}$ \\
\hline $\begin{array}{l}\text { Nidera Paraguay Granos y } \\
\text { Oleaginosas S.A. - } \\
\text { HOLANDA (n) }\end{array}$ & $\begin{array}{l}\text { Fornecimento } \\
\text { de insumos; } \\
\text { coleta e } \\
\text { comercialização }\end{array}$ & $\begin{array}{l}\text { A Nidera Paraguay é subsidiária da transnacional NIDERA (com matriz na Holanda), que também tem importantes sedes regionais na } \\
\text { Argentina e no Brasil. Na região, a empresa se orienta basicamente ao fornecimento de insumos agrícolas (sementes e pacote } \\
\text { tecnológico de cultivo) e também à produção, coleta e comercialização de grãos (milho, soja, sorgo). No Paraguai, a empresa se orienta } \\
\text { à comercialização de insumos, assim como à exportação de grãos. Também realiza suas operaçôes por meio da empresa Copatia S.A., } \\
\text { que tem licença oficial das divisões de "NIDERA Sementes Brasil" e "Nidera Semillas Argentina". É associada à CAPECO. }\end{array}$ \\
\hline $\begin{array}{l}\text { Noble Paraguay S.A. - } \\
\text { HONG KONG (o) }\end{array}$ & $\begin{array}{l}\text { Fornecimento } \\
\text { de insumos; } \\
\text { coleta e } \\
\text { comercialização }\end{array}$ & $\begin{array}{l}\text { Noble Paraguay faz parte do Noble Group, empresa multinacional com matriz em Hong Kong, dedicada ao comércio global de } \\
\text { commodities agrícolas (grãos e sementes oleaginosas, café, cacau, açúcar, etc.), produtos de energia (carvão, petróleo e gás), metais e } \\
\text { minerais. No Paraguai, a empresa opera fornecendo insumos agrícolas (agroquímicos e fertilizantes), coletando e exportando grãos e } \\
\text { sementes oleaginosas. É sócia da CAPECO e da CAPPRO. }\end{array}$ \\
\hline $\begin{array}{c}\text { Syngenta Paraguay S.A - } \\
\text { SUÍÇA (p) }\end{array}$ & $\begin{array}{l}\text { Fornecimento } \\
\text { de insumos }\end{array}$ & $\begin{array}{l}\text { A Syngenta é uma multinacional de origem Suíça, dedicada à elaboração de produtos para a proteção de cultivos, sementes, entre outros } \\
\text { produtos agrícolas. No Paraguai, a multinacional operava desde } 2003 \text { por meio da firma local AGROSAN S. A., que importava e } \\
\text { distribuía seus produtos exclusivamente. Em } 2010 \text { a Syngenta adquiriu } 100 \% \text { das ações da AGROSAN S.A. incorporando-a, e } \\
\text { mantendo os mesmos serviços de importação e venda de suas marcas de agroquímicos. É associada à CAPECO. }\end{array}$ \\
\hline $\begin{array}{l}\text { Unilever de Paraguay S.A. - } \\
\text { HOLANDA/UK (Q) }\end{array}$ & $\underset{(* *)}{\text { Industrialização }}$ & $\begin{array}{l}\text { A UNILEVER Paraguay é filial da Unilever Global. No Paraguai, atua como importadora de produtos elaborados pela transnacional em } \\
\text { outros países, produtos do meio alimentício, limpeza e higiene pessoal }(* *) \text {. A ContiParaguay (na qual a Unilever tem participação } \\
\text { acionária), industrializa alguns de seus produtos dentro do país, como azeites e farinhas (e, por isso, pode-se dizer que a Unilever realiza } \\
\text { uma parte de suas atividades de industrialização localmente). }\end{array}$ \\
\hline
\end{tabular}

\section{LEGENDA}

(a) http://www.adm.com/en-US/worldwide/paraguay/Pages/default.aspx

(b) http://www.agritrade.com/

(c) http://www.bayer.com/en/profile-and-organization.aspx

(d) http://www.bungeparaguay.com/

(e) http://www.cargill.com.py/

(f) http://www.chsinc.com/our-company

(f) http://noticias.terra.es/mundo/latinoamerica/chs-espera-duplicar-su-negocio-de-granos-en-sudamerica,e2f8aef65799b310VgnCLD2000000dc6eb0aRCRD.html. Acesso em 24.04.2014

(g) Notícia no site da Bunge: http://www.bungeparaguay.com/?q=node/50; Notícia no site do BID: http://www.iadb.org/es/proyectos/project-information-page,1303.html?id=PR-L1071;

Notícia no Jornal ABC: http://www.abc.com.py/edicion-impresa/economia/inauguran-aceitera-que-requirio-de-una-inversion-de-us-200-millones-1198460.html. Acesso 24.04.2014

(h) http://www.contiparaguay.com.py/

(i) http://www.dowagro.com/py/ 
(J) http://www.jbs.com.br; http://www.jbs.com.py/

(J) Notícia no Jornal ABC: http://www.abc.com.py/edicion-impresa/economia/el-60-de-frigorificos-exportadores-son-controlados-por-firmas-brasilenas-482655.html. Acesso em 24.04.14.

(k) http://www.ldcommodities.com/about-us/

(L) http://www.monsanto.com/global/py/pages/default.aspx

(m) Rojas (2009); e http://www.nestle.com.py/

(n) http://www.nidera.com.ar/Nidera/compania.aspx?mnu=companiaMnuNidera; http://www.niderasementes.com.br/conteudo/historia.aspx;

(n) http://www.copatia.com.py/Copatia/index.html

(o) http://www.thisisnoble.com/

(p) http://www.syngenta.com/global/corporate/en/about-syngenta/countries/Pages/py.aspx

(p) Informação sobre aquisição disponível no Jornal La Nación: http://www.lanacion.com.py/articulo.php?art=7013. Acesso em 24.04.2014

(Q) Rojas (2009); e http://www.unilever.com.py/

Fonte: Elaboração própria a partir de Rojas (2009:33-47); páginas web das empresas (ver Legenda); páginas web das associações de grêmio (CAPPRO e CAPECO); e publicações em jornais 
Tabela 22 - Outras empresas estrangeiras do agronegócio instaladas no Paraguai - 2013

\begin{tabular}{|c|c|c|}
\hline $\begin{array}{c}\text { Empresa / País de } \\
\text { Origem }\end{array}$ & $\begin{array}{c}\text { Principais } \\
\text { segmentos de } \\
\text { atuação }\end{array}$ & Descrição geral da empresa \\
\hline $\begin{array}{l}\text { ARCORPAR S.A. - } \\
\text { ARGENTINA (a) }\end{array}$ & $\begin{array}{c}\text { Industrialização } \\
(* *)\end{array}$ & $\begin{array}{l}\text { A ARCORPAR é a filial da empresa ARCOR de origem argentina, que atua no segmento de produtos alimentícios. A ARCOR é considerada } \\
\text { uma das maiores empresas da América Latina - figura na posição n. 183, entre as } 500 \text { maiores empresas da América Latina, de acordo com a } \\
\text { CEPAL (2012:105). A filial paraguaia, ARCORPAR, foi a primeira filial da empresa no exterior, em 1978. (**) A empresa opera importando os } \\
\text { produtos (alimentos elaborados, isto é, já industrializados) da marca ARCOR e os comercializa no país. }\end{array}$ \\
\hline $\begin{array}{l}\text { Colonización y } \\
\text { Transformación } \\
\text { Agraria S.A. - } \\
\text { CYTASA - ESPANA } \\
\quad \text { (b) }\end{array}$ & $\begin{array}{l}\text { Produção; coleta e } \\
\text { comercialização }\end{array}$ & $\begin{array}{l}\text { A CYTASA é uma filial do Grupo TRAGSA, que constitui um grupo de empresas especializadas no desenvolvimento rural e conservação } \\
\text { ambiental, formando parte da "Sociedade Estatal de Participações Industriais" (empresa pública espanhola). A atividade internacional do Grupo } \\
\text { TRAGSA acontece principalmente através de projetos de cooperação para o desenvolvimento, tanto bilateral como multilateral. No Paraguai, a } \\
\text { empresa de transformação agrária se dedica ao cultivo e transformação agrícola, pecuária e florestal, e à comercialização dos produtos obtidos } \\
\text { nos mercados interno e externo. A CYTASA faz parte da iniciativa global de promoção do cultivo de soja responsável (RTRS). É associada à } \\
\text { CAPECO. }\end{array}$ \\
\hline $\begin{array}{l}\text { Compañía Paraguaya } \\
\text { de Granos } \\
\text { (COPAGRA) - } \\
\text { ARGENTINA (c ) }\end{array}$ & $\begin{array}{l}\text { Coleta e } \\
\text { comercialização; } \\
\text { industrialização }\end{array}$ & Empresa de origem argentina dedicada ao processamento de grãos e sementes oleaginosas. É associada à CAPRRO. \\
\hline $\begin{array}{l}\text { Desarrollo Agrícola } \\
\text { del Paraguay S.A. } \\
\text { (DAP) - ARGENTINA } \\
\text { (d) }\end{array}$ & $\begin{array}{c}\text { Produção; coleta e } \\
\text { comercialização }\end{array}$ & $\begin{array}{l}\text { Criada em 2005. A DAP é uma subsidiária da firma NFD Agro - projeto da empresa NFDevelopers, especializada no desenvolvimento do } \\
\text { agronegócio na região da América do Sul, e sediada na Argentina. No Paraguai, a DAP trabalha na expansão da fronteira agrícola na região norte } \\
\text { do país (departamento de San Pedro), cultivando, principalmente, soja, e em menor medida, milho e girassol. Atualmente, trabalha em uma } \\
\text { extensão de aproximadamente } 20 \text { mil hectares, dos quais } 11 \text { mil são próprios e o restante é alugado. A DAP corresponde a uma primeira fase do } \\
\text { projeto de expansão das inversões do NFD no setor agrícola na região, cujas próximas fases incluem o aumento das inversões para a expansão da } \\
\text { fronteira agrícola no Brasil, e o desenvolvimento de uma empresa de produção de etanol no Paraguai. A DAP também é conhecida por promover } \\
\text { o programa de produção de soja responsável (que diminuiria os efeitos negativos da expansão do monocultivo) participando da iniciativa } \\
\text { internacional "Mesa redonda de Soja Responsável" (RTRS), na qual participam outras firmas como a CARGILL, BUNGE e UNILEVER. }\end{array}$ \\
\hline $\begin{array}{l}\text { Grupo Minerva - } \\
\text { BRASIL (e) }\end{array}$ & $\begin{array}{l}\text { Produção; coleta e } \\
\text { comercialização; } \\
\text { industrialização }\end{array}$ & $\begin{array}{l}\text { Minerva Foods é uma empresa de origem brasileira, sendo uma das maiores empresas da América Latina. Opera na produção e comercialização } \\
\text { de carne bovina, couro e derivados, e no processamento de carne bovina, suína e de aves. Seus frigoríficos e centros de distribuição se encontram } \\
\text { em } 10 \text { estados do Brasil, no Paraguai e no Uruguai. A empresa também possui operações e escritório em outros países fora da região. No } \\
\text { Paraguai, a empresa adquiriu os frigoríficos "Frigomerc" (em 2012) e "FRIASA" (em 2008, que foi, por sua vez, fusionada com a Frigomerc em } \\
\text { 2014). Ambas as unidades se dedicam ao processamento e exportação de carne, contanto também com criação própria de gado. O Grupo Minerva } \\
\text { aparece na posição n. } 274 \text { entre as } 500 \text { maiores empresas de América Latina (CEPAL, 2012:105). }\end{array}$ \\
\hline
\end{tabular}




\begin{tabular}{|c|c|c|}
\hline $\begin{array}{l}\text { LAR S.R.L. - BRASIL } \\
\text { (f) }\end{array}$ & $\begin{array}{l}\text { Fornecimento de } \\
\text { insumos; coleta e } \\
\text { comercialização }\end{array}$ & $\begin{array}{l}\text { A LAR S.R.L. é uma empresa ligada à Cooperativa LAR do Brasil, que atua no setor agropecuário brasileiro: na produção e comercialização de } \\
\text { grãos (soja, milho, trigo, etc.) e também de produtos pecuários, possuindo mais de } 8 \text { mil associados. Sua sede é em Medianera, no estado de } \\
\text { Paraná (Brasil). No Paraguai, a LAR tem uma estrutura de sete unidades que atuam na recepção e comercialização de grãos, na venda de insumos } \\
\text { agrícolas e na assistência técnica aos produtores rurais da região. Em } 2005 \text {, a cooperativa recebeu financiamento do BNDES para a expansão das } \\
\text { suas operações no Paraguai, no marco da política de apoio à internacionalização de empresas brasileiras. É associada à CAPECO. }\end{array}$ \\
\hline $\begin{array}{l}\text { Paraguay Agricultural } \\
\text { Corporation (PAYCO) } \\
\text { - Rio Forte - Grupo } \\
\text { Espírito Santo - } \\
\text { PORTUGAL (g) }\end{array}$ & $\begin{array}{l}\text { Produção; coleta e } \\
\text { comercialização }\end{array}$ & $\begin{array}{l}\text { A PAYCO é uma holding que integra três empresas: a "Sociedade Agrícola Golondrina S. A. (SAGSA)", a "Ganadera Corina Campos y } \\
\text { Hacienda S.A." e o projeto de "Forestería Certificada del Paraguay" (FORCERPA). As três empresas juntas exploram no país uma área em torno } \\
\text { de } 135 \text { mil hectares. A produção agrícola se orienta para os cultivos de soja, algodão, trigo e girassol. As pastagens estão dedicadas à criação de } \\
\text { gado bovino. Já na área florestal, a empresa está dedicada à produção de eucalipto, possuindo também uma reserva privada. A PAYCO foi criada } \\
\text { em janeiro de } 2013 \text {, como reflexo de uma reestruturação da firma "RioForte", que constitui a sociedade de investimentos não financeiros do } \\
\text { Grupo Espírito Santo. O Grupo Espírito Santo é um conglomerado de empresas de origem português que oferecem serviços financeiros (bancos, } \\
\text { investimentos, seguros) e não financeiros (por meio da firma "Rio Forte"). Em seu portfólio de investimentos não financeiros, o grupo tem } \\
\text { inversões nos setores imobiliários, turístico, agropecuário, e de energia. }\end{array}$ \\
\hline $\begin{array}{l}\text { Sociedade Agrícola } \\
\text { Golondrina (SAGSA) } \\
\qquad(\text { g) }\end{array}$ & $\begin{array}{l}\text { Produção; coleta e } \\
\text { comercialização }\end{array}$ & $\begin{array}{l}\text { O início de suas atividades remonta a 1979. Desde então, já foram adquiridos } 24.000 \text { hectares de lote destinados para a atividade agrícola e } \\
\text { agroindustrial, que se distribuem da seguinte forma: } 7.000 \text { ha. para agricultura; } 5000 \text { ha. para pastagem; e } 12.000 \text { ha. de reserva natural. Na } \\
\text { atividade agrícola, a SAGSA se dedica ao cultivo de soja, algodão, milho, girassol e trigo. Além disso, tem criação de gado, e atua na } \\
\text { comercialização de sementes e exportação de madeira. É associada à CAPECO. }\end{array}$ \\
\hline $\begin{array}{l}\text { Forestería Certificada } \\
\text { del Paraguay } \\
\text { (FORCERPA) }(\text { g) }\end{array}$ & Produção & $\begin{array}{l}\text { É um projeto nasce de um convênio assinado entre a "Sociedade Agrícola Golondrina" e a "Unique Wood Paraguay S.A.". O projeto se orienta } \\
\text { às atividades de exploração e exportação de madeira, desempenhando-se dentro da propriedade da SAGSA. }\end{array}$ \\
\hline $\begin{array}{l}\text { Ganadera Corina } \\
\text { Campos y Hacienda } \\
(\mathrm{g})\end{array}$ & Produção & $\begin{array}{l}\text { A ganadera é adquirida em 1997. A produção se realiza em cinco fazendas próprias. A primeira fazenda conta com } 35.109 \text { hectares; a segunda } \\
\text { com } 8.679 \text { hectares; a terceira (e maior) com } 36.408 \text { hectares; a quarta, no Chaco, com 9.341; e uma última, adquirida em } 2012 \text {, com } 12.732 \\
\text { hectares. Em total, seriam } 102.269 \text { hectares. }\end{array}$ \\
\hline $\begin{array}{l}\text { Shirosawa Company } \\
\text { S.A.I.C - JAPÓN (h) }\end{array}$ & $\begin{array}{l}\text { Coleta e } \\
\text { comercialização; } \\
\text { industrialização }\end{array}$ & $\begin{array}{l}\text { Shirosawa Company é uma empresa de origem japonesa que se instalou no Paraguay em 1971. Atualmente, é uma das líderes no processamento } \\
\text { e exportação de sésamo, amendoim e produtos alimentícios derivados. }\end{array}$ \\
\hline $\begin{array}{l}\text { Tierra Roja S.A. - } \\
\text { ARGENTINA (i) }\end{array}$ & $\begin{array}{l}\text { Produção; coleta e } \\
\text { comercialização }\end{array}$ & $\begin{array}{l}\text { A empresa Tierra Roja S.A. faz parte do grupo empresarial argentino "Los Grobo". O grupo "Los Grobo" é um conglomerado de empresas } \\
\text { líderes no agronegócio na região do Cone Sul, estando presente no Brasil, na Argentina, no Uruguai e no Paraguai. O grupo atua em uma } \\
\text { diversidade de setores, desde a produção em si, passando pelo fornecimento de insumos e serviços técnicos e financeiros, até o processamento e } \\
\text { industrialização das commodities produzidas. Em conjunto, o Grupo se coloca como um dos principais produtores de grãos na região. Sua } \\
\text { subsidiária no Paraguai, a Tierra Roja S.A., foi criada em 2005, e cultiva em torno de } 22.000 \text { hectares, além de contar com silos para } \\
\text { armazenagem da produção. }\end{array}$ \\
\hline
\end{tabular}




\begin{tabular}{|c|c|c|}
\hline $\begin{array}{c}\text { Vicentin Paraguay } \\
\text { S.A. - ARGENTINA } \\
\text { (J) }\end{array}$ & $\begin{array}{c}\text { Coleta e } \\
\text { comercialização }\end{array}$ & $\begin{array}{l}\text { A empresa Vicentin Paraguay pertence ao Grupo Vicentin, corporação argentina orientada ao processamento e industrialização de commodities } \\
\text { agrícolas. Nas suas plantas industriais na Argentina, produz óleos vegetais e farinhas, a partir de cultivos de soja, algodão, e girassol, sendo } \\
\text { também pioneira na produção e exportação de biodiesel nesse país. Em } 2005 \text {, o grupo começou suas atividades no Paraguai por meio da Vicentin } \\
\text { Paraguay, dedicando-se à coleta e exportação de grãos de soja, a fim de atender a demanda crescente de suas plantas industriais na Argentina. É } \\
\text { associada à CAPECO. }\end{array}$ \\
\hline
\end{tabular}

\section{LEGENDA}

(a) http://www.arcor.com/Arcor_es_oficinasMundo_paraguay_40.aspx

(b) http://www.tragsa.es/es/acerca-del-grupo/Paginas/Internacional.aspx

(b) http://www.sepi.es/default.aspx?cmd=0004\&IdContent=11152\&idLanguage=\#Compa\%C3\%B1\%C3\%ADas participadas

(b) http://www.tragsa.es/es/sala-de-prensa/noticias/Paginas/Cytasa,primeraempresacertificadaenParaguaycomoproductoradesojaresponsable.aspx

(c) http://cappro.org.py/

(d) http://www.dap.com.py/index.php; http://www.nfdevelopers.com/NFD Agro.htm

(e) http://portal.minervafoods.com/frigomerc/quem-somos; http://portal.minervafoods.com/frigomerc/frigomerc-apresentacao

(e) http://ri.minervafoods.com/minerva2012/web/conteudo_pt.asp?idioma=0\&conta=28\&tipo=40367

(f) http://www.lar.ind.br/v3/coligadas.php

(g) http://www.rioforte.pt/portfolio/foco-geografico/america-sul/payco/; http://payco.multired.com.py/

(g) http://www.rioforte.pt/o-grupo/rioforte-em-numeros/; http://payco.multired.com.py/esp/ganadera_corina_campos_y_haciendas

(h) http://www.shirosawaco.com/home.php

(i) http://www.losgrobo.com/en/tierra-roja.html

Outras informações sobre o Grupo Los Grobo, no Jornal 'Fusiones e Aquisições': http://www.diariodefusiones.com/?page=ampliada\&id=191. Acesso em 24.04.2014

(J) http://www.vicentin.com.ar/index.php/historia

Fonte: Elaboração própria a partir de Rojas (2009:47-51); páginas web das empresas (ver Legenda); páginas web das associações de grêmio (CAPPRO e CAPECO); e publicações em jornais 
Tabela 23 - Empresas locais do agronegócio no Paraguai - 2013

\begin{tabular}{|c|c|c|c|}
\hline Empresa & $\begin{array}{l}\text { País de } \\
\text { vínculo* }\end{array}$ & $\begin{array}{l}\text { Principais } \\
\text { segmentos de } \\
\text { atuação }\end{array}$ & Descrição geral da empresa \\
\hline $\begin{array}{l}\text { Aceites y Derivados } \\
\text { S.A. (ADESA) (a) }\end{array}$ & - & $\begin{array}{l}\text { Coleta e } \\
\text { comercialização; } \\
\text { industrialização. }\end{array}$ & $\begin{array}{l}\text { A empresa processa diversos cultivos oleaginosos, como girassol, canola, soja e semente de algodão, para a obtenção de óleos vegetais } \\
\text { e produtos para ração animal. Atualmente, a maior parte de sua produção se destina para exportação, a mercados de América Latina e } \\
\text { Europa, onde o óleo exportado é utilizado na produção de biodiesel. É associada à CAPPRO. }\end{array}$ \\
\hline $\begin{array}{l}\text { Agrícola Colonial } \\
\text { S.A.I.C. (b) }\end{array}$ & Brasil & $\begin{array}{l}\text { Fornecimento de } \\
\text { insumos; coleta e } \\
\text { comercialização }\end{array}$ & $\begin{array}{l}\text { Empresa criada em } 2004 \text { por imigrantes brasileiros, dedicada à comercialização de insumos agrícolas (agroquímicos, fertilizantes, } \\
\text { sementes), ao fornecimento de serviços técnicos, e à coleta e comercialização de grãos e cereais (soja, milho, trigo). É associada à } \\
\text { CAPECO. }\end{array}$ \\
\hline $\begin{array}{l}\text { Agro Santa Rosa } \\
\text { S.A.E. (c) }\end{array}$ & Brasil & $\begin{array}{l}\text { Fornecimento de } \\
\text { insumos; coleta e } \\
\text { comercialização }\end{array}$ & $\begin{array}{l}\text { A empresa se dedica a produzir e exportar grãos e sementes. Um dos proprietários da empresa é o Sr. Oscar L. Lourenço, que é } \\
\text { também presidente da empresa CIABAY S.A. A empresa também se vincula com a firma Agroser S.A. e Agrícola Santa Mariana, que } \\
\text { têm os mesmos proprietários. É associada à CAPECO. }\end{array}$ \\
\hline $\begin{array}{l}\text { Agro Silos El } \\
\text { Productor (d) }\end{array}$ & - & $\begin{array}{c}\text { Coleta e } \\
\text { comercialização }\end{array}$ & Empresa agroexportadora. Figura entre as principais exportadoras de 2013 no ranking da CIP. A empresa está associada à CAPECO. \\
\hline Agrofértil S.A. (e) & Brasil & $\begin{array}{l}\text { Fornecimento de } \\
\text { insumos; coleta e } \\
\text { comercialização }\end{array}$ & $\begin{array}{l}\text { Empresa importadora e comerciante de insumos agrícolas (fertilizantes, sementes e agroquímicos). Também realiza coleta e } \\
\text { comercialização (exportação) de grãos. É uma das principais representantes de Monsanto no país. O presidente da empresa é o } \\
\text { brasileiro José Marcos Saraiva, também presidente da empresa Tecnomyl. A empresa é associada da CAPECO. }\end{array}$ \\
\hline $\begin{array}{l}\text { Agropecuaria } \\
\text { Busanello S.A (f) }\end{array}$ & Brasil & $\begin{array}{l}\text { Produção; coleta } \\
\text { e comercialização }\end{array}$ & $\begin{array}{l}\text { Empresa fundada por uma família de migrantes brasileiros. A empresa se dedica à produção agrícola mecanizada (soja, trigo, milho e } \\
\text { sorgo), criação de gado e de peixes. Atualmente contam com } 3700 \text { hectares para cultivo. Possuem silos próprios para o armazenamento } \\
\text { da produção. }\end{array}$ \\
\hline Agroser S.A. (g) & Brasil & $\begin{array}{l}\text { Fornecimento de } \\
\text { insumos; coleta e } \\
\text { comercialização }\end{array}$ & $\begin{array}{l}\text { Empresa produtora e exportadora de grãos. Está vinculada às empresas CIABAY S.A., Agro Santa Rosa S.A.E., e Agrícola Santa } \\
\text { Mariana S.A. que têm os mesmos proprietários. É sócia da CAPECO. }\end{array}$ \\
\hline Agrotec S.A. (h) & Brasil & $\begin{array}{l}\text { Fornecimento de } \\
\text { insumos; coleta e } \\
\text { comercialização }\end{array}$ & $\begin{array}{l}\text { Empresa fornecedora de insumos agrícolas (importa e comercializa agroquímicos da marca de empresas transnacionais e também tem } \\
\text { suas próprias marcas) e de serviços técnicos aos produtores. Também realiza a coleta e exportação de grãos. Pertence ao Grupo } \\
\text { Agrihold, cujo presidente é o brasileiro Túlio Luiz Neves Zanchet. O grupo conta com outras empresas no segmento agroindustrial } \\
\text { paraguaio, relacionadas às atividades de fornecimento de insumos e serviços técnicos para a produção agrícola. É associada à } \\
\text { CAPECO. }\end{array}$ \\
\hline $\begin{array}{l}\text { Alberto Giles } \\
\text { Agroexportadora } \\
\text { ALGISA (i) }\end{array}$ & - & $\begin{array}{l}\text { Coleta e } \\
\text { comercialização; } \\
\text { industrialização }\end{array}$ & $\begin{array}{l}\text { Empresa voltada ao processamento de grãos oleaginosos. Elabora e comercializa, principalmente, óleos vegetais. É associada à } \\
\text { CAPPRO. }\end{array}$ \\
\hline
\end{tabular}




\begin{tabular}{|c|c|c|c|}
\hline $\begin{array}{l}\text { Comercial e Industrial } \\
\text { Amambay - CIABAY } \\
\quad \text { S.A (J) }\end{array}$ & Brasil & $\begin{array}{l}\text { Fornecimento de } \\
\quad \text { insumos }\end{array}$ & $\begin{array}{l}\text { Empresa comercializadora de insumos agrícolas (maquinarias, agroquímicos e fertilizantes). A empresa importa e comercializa } \\
\text { insumos agrícolas, representando marcas como BAYER (agroquímicos); CASE IH, NEW HOLLAND e TATUMARCHESAN } \\
\text { (maquinarias), entre outras marcas. O presidente da empresa é o brasileiro Oscar L. Lourenço. Está vinculada a outras empresas que } \\
\text { também aparecem sob o nome do brasileiro: a empresa Agro Santa Rosa S.A.E.; a Agroser e a Agrícola Santa Mariana. }\end{array}$ \\
\hline Dekalpar S.A. (k) & - & $\begin{array}{l}\text { Fornecimento de } \\
\text { insumos }\end{array}$ & $\begin{array}{l}\text { Empresa importadora e comercializadora de insumos agrícolas. Também oferece serviços técnicos aos agricultores, e conta com } \\
\text { produção agrícola própria (principalmente de soja e milho). É associada à CAPECO. }\end{array}$ \\
\hline Diagro S.A (L) & Brasil & $\begin{array}{l}\text { Fornecimento de } \\
\text { insumos; coleta e } \\
\text { comercialização }\end{array}$ & $\begin{array}{l}\text { Empresa fundada em } 1991 \text { pelos brasileiros Jaime Zorzetto, Joacir Alves e Gilberto Rubert. Começou suas atividades com a } \\
\text { importação e comercialização de insumos agrícolas. Em } 2002 \text { passou a realizar coleta, armazenagem e comercialização de grãos (soja, } \\
\text { trigo e milho). }\end{array}$ \\
\hline $\begin{array}{l}\text { Enrique Remmele } \\
\text { S.A.C.I (ERSA) (m) }\end{array}$ & - & $\begin{array}{l}\text { Coleta e } \\
\text { comercialização; } \\
\text { industrialização }\end{array}$ & $\begin{array}{l}\text { Empresa dedicada ao processamento de produtos agrícolas, principalmente à elaboração de farinhas e ração animal. Elabora e } \\
\text { comercializa a conhecida marca de farinha de trigo ERSA. Além disso, realiza a exportação de farinha de trigo, gordura bovina, farinha } \\
\text { de carne e osso. Também realiza importação de motores e acessórios para linhas náuticas. É associada à CAPECO. }\end{array}$ \\
\hline Grupo Favero (n) & Brasil & $\begin{array}{l}\text { Fornecimento de } \\
\text { insumos; } \\
\text { produção; coleta } \\
\text { e comercialização }\end{array}$ & $\begin{array}{l}\text { É um dos maiores grupos empresariais do agronegócio no Paraguai. O seu principal proprietário é Tranquilo Favero, brasileiro que } \\
\text { migrou para o país nos anos 1970, e atualmente possui nacionalidade paraguaia. O empresário é frequentemente chamado como o "rei } \\
\text { da soja", pois é um dos maiores produtores e exportadores desse cultivo no país. O grupo conta com nove empresas que se orientam a } \\
\text { diferentes segmentos da cadeia do agronegócio. Rojas (2009) estima que o grupo seria proprietário de aproximadamente } 140 \mathrm{mil} \\
\text { hectares. É associada à CAPECO. }\end{array}$ \\
\hline $\begin{array}{l}\text { Agro Silo Santa } \\
\text { Catalina S.A. (n) }\end{array}$ & - & $\begin{array}{l}\text { Fornecimento de } \\
\quad \text { insumos; } \\
\text { produção; coleta } \\
\text { e comercialização }\end{array}$ & $\begin{array}{l}\text { Empresa pioneira do Grupo Favero, que se dedica à produção, coleta e comercialização de bens agrícolas, principalmente de soja, além } \\
\text { de trigo, girassol, canola e milho. Também se encarrega da compra e venda de agroquímicos, máquinas, e à venda e aluguel de terras. } \\
\text { Seus engenheiros agrônomos acompanham as atividades de produção tanto da empresa como dos produtores independentes na região } \\
\text { adjacente a seus armazéns (conta com } 13 \text { unidades de armazenamento, distribuídos na região Oriental do país). É associada à } \\
\text { CAPECO. }\end{array}$ \\
\hline Agrotoro S.A. (n) & - & $\begin{array}{l}\text { Fornecimento de } \\
\text { insumos; } \\
\text { produção; coleta } \\
\text { e comercialização }\end{array}$ & $\begin{array}{l}\text { É uma empresa do grupo dedicada à produção e comercialização de grãos, sementes e insumos agrícolas (fertilizantes e máquinas). } \\
\text { Oferece serviços de coleta, assessoramento técnico, aluguel de terras, entre outros serviços. No território ocupado pela empresa se } \\
\text { encontra a reserva natural de Ñacunday. É sócia da CAPECO. }\end{array}$ \\
\hline Aktra S.A. (n) & - & $\begin{array}{l}\text { Fornecimento de } \\
\text { insumos }\end{array}$ & $\begin{array}{l}\text { Empresa do grupo Favero dedicada ao fornecimento do pacote tecnológico para produção agrícola. Conta com uma planta industrial } \\
\text { que importa, elabora e comercializa agroquímicos. }\end{array}$ \\
\hline $\begin{array}{l}\text { Ganadera Campo } \\
\text { Bello (n) }\end{array}$ & - & Produção & Dedicada à criação de gado, através de um complexo de fazendas (seis no total) no departamento de Boquerón, na região do Chaco. \\
\hline $\begin{array}{l}\text { Ganadera Forestal } \\
\text { Santa Catalina (n) }\end{array}$ & - & Produção & Dedicada à criação de gado, contando com quatro fazendas na região do Chaco. \\
\hline $\begin{array}{l}\text { Agro Ganadera San } \\
\text { Liberato (n) }\end{array}$ & - & Produção & $\begin{array}{l}\text { Dedicada à criação de gado, contando com duas fazendas (uma no departamento de Boquerón, e outra no departamento de } \\
\text { Concepción). }\end{array}$ \\
\hline
\end{tabular}




\begin{tabular}{|c|c|c|c|}
\hline Semillas Verónica (n) & - & $\begin{array}{l}\text { Fornecimento de } \\
\text { insumos }\end{array}$ & $\begin{array}{l}\text { É uma divisão da empresa Agro Silo Santa Catalina, dedicada integralmente à pesquisa, desenvolvimento, produção e distribuição de } \\
\text { sementes oleaginosas (principalmente soja). Possui convenio com a EMBRAPA, e com empresas como SYNGENTA e Nidera. }\end{array}$ \\
\hline Totem S.A. (n) & - & (Transporte) & $\begin{array}{l}\text { É o porto privado do Grupo Favero na margem do Rio Paraná, no distrito de Ñacunday. Oferece serviços de venda de combustível, } \\
\text { aluguel de terras, coleta e transporte de grãos. }\end{array}$ \\
\hline Trafa S.A. (n) & - & $\begin{array}{l}\text { Fornecimento de } \\
\text { insumos }\end{array}$ & $\begin{array}{l}\text { É uma divisão da empresa Agro Silo Santa Catalina. Dedica-se à comercialização de maquinarias agrícolas (sendo representante da } \\
\text { marca New Holland). Também presta serviços técnicos. }\end{array}$ \\
\hline Grupo Kress (o) & - & $\begin{array}{l}\text { Produção; coleta } \\
\text { e } \\
\text { comercialização; } \\
\text { industrialização }\end{array}$ & $\begin{array}{l}\text { Grupo de empresas dedicadas à produção agrícola e processamento de cultivos. Foi fundada por migrantes alemães. Suas principais } \\
\text { unidades empresariais são: a "Estancia Beate Verónica Holtker"; a "Frutika S.R.L."; e a "Kimex S.R.L.". }\end{array}$ \\
\hline $\begin{array}{l}\text { Estancia Beate } \\
\text { Verónica Holtker (o) }\end{array}$ & - & $\begin{array}{l}\text { Produção; coleta } \\
\text { e comercialização }\end{array}$ & $\begin{array}{l}\text { Empresa do Grupo Kress dedicada à produção agrícola e frutícola. } 70 \% \text { da produção de grãos são exportados, e o restante vendido no } \\
\text { mercado nacional. É sócia da CAPECO. }\end{array}$ \\
\hline Frutika S.R.L (o) & - & Industrialização & $\begin{array}{l}\text { Empresa dedicada ao processamento e comercialização de frutas, vegetais, sucos e concentrados de suco. A empresa foi a primeira do } \\
\text { país a exportar sucos concentrados. }\end{array}$ \\
\hline Kimex S.R.L. (o) & - & $\begin{array}{l}\text { Fornecimento de } \\
\text { insumos; coleta e } \\
\text { comercialização }\end{array}$ & $\begin{array}{l}\text { Foi a primeira empresa do grupo Kress. Tem como principal atividade a comercialização de insumos agrícolas e sementes, assim como } \\
\text { a coleta de grãos. }\end{array}$ \\
\hline $\begin{array}{l}\text { Industria Paraguaya } \\
\text { de Alcoholes S.A. } \\
\text { INPASA (p) }\end{array}$ & - & $\begin{array}{l}\text { Produção; coleta } \\
\text { e } \\
\text { comercialização; } \\
\text { industrialização }\end{array}$ & $\begin{array}{l}\text { Empresa fundada em 2006, dedicada à produção de etanol (principalmente a partir de milho e sorgo); à elaboração de açúcar cristal; e } \\
\text { de outros subprodutos derivados do processo industrial de elaboração dos biocombustíveis (como óleos vegetais e raçáo animal). A } \\
\text { produção e exportação de cultivos mecanizados (soja e milho) também aparecem como atividades da empresa. Além da planta } \\
\text { industrial, conta com } 7.000 \text { hectares de plantação própria de cana de açúcar. De acordo com a sua página web, é a maior produtora de } \\
\text { etanol de milho na América Latina. É associada à CAPECO. }\end{array}$ \\
\hline $\begin{array}{l}\text { MOLINOS } \\
\text { HARINEROS DEL } \\
\text { PARAGUAY (Q) }\end{array}$ & Argentina & Industrialização & $\begin{array}{l}\text { Empresa fundada em 1929, dedicada à elaboração de farinha e ração animal, a partir do trigo. Em } 1999 \text { CARGILL havia adquirido } \\
\text { parte do seu pacote acionário da empresa. Em 2005, a empresa argentina Rinehart S.A. adquiriu a parte de CARGILL tornando-se co- } \\
\text { proprietária com os investidores nacionais. }\end{array}$ \\
\hline $\begin{array}{l}\text { Oleaginosa RAATZ } \\
\text { S.A. (R) }\end{array}$ & - & $\begin{array}{l}\text { Coleta e } \\
\text { comercialização; } \\
\text { industrialização }\end{array}$ & $\begin{array}{l}\text { Empresa fundada em } 1967 \text { na região de Itapúa, por descendentes de migrantes europeus. Atualmente à empresa processa diversos } \\
\text { cultivos, como soja, canola, girassol e algodão, elaborando e comercializando óleos industriais e de consumo; farinhas e produtos para } \\
\text { alimentação animal. É associada à CAPPRO. }\end{array}$ \\
\hline Ovetril S.A. (s) & Brasil & $\begin{array}{c}\text { Coleta e } \\
\text { comercialização }\end{array}$ & Empresa agroexportadora. Seu gerente é o brasileiro Lindemar Cesca. É associada à CAPECO. \\
\hline
\end{tabular}




\begin{tabular}{|c|c|c|c|}
\hline$\underset{\text { (t) }}{\text { Salto Aguaray S.R.L }}$ & - & $\begin{array}{c}\text { Coleta e } \\
\text { comercialização }\end{array}$ & $\begin{array}{l}\text { Empresa agroexportadora, dedicada à coleta e exportação de grãos. Localizada ao norte da região oriental, a } 15 \mathrm{~km} \text {. da cidade de San } \\
\text { Pedro, no distrito de Puerto Antequera. A empresa se coloca como pioneira de exportação de grãos na região, principalmente de soja e } \\
\text { milho. É associada à CAPECO. }\end{array}$ \\
\hline Tecnomyl S.A. (u) & Brasil & $\begin{array}{l}\text { Fornecimento de } \\
\text { insumos }\end{array}$ & $\begin{array}{l}\text { Empresa líder na produção e comercialização de agroquímicos. Importa matéria prima para a elaboração de seus agroquímicos e } \\
\text { fertilizantes. Possui um laboratório na cidade de Córdoba (na Argentina), orientado à pesquisa e inovação dos produtos. A fábrica e as } \\
\text { operações administrativas estão sediadas no Paraguai. Com sua produção atende a } 20 \% \text { do mercado local, e também exporta para } \\
\text { Bolívia, Argentina e Brasil. Um de seus diretivos é José Marcos Saraiva, também diretivo da Agrofértil. }\end{array}$ \\
\hline $\begin{array}{l}\text { TROCIUK \& } \\
\text { Compañía Agrícola } \\
\text { Ganadera Industrial } \\
\text { S.A. (v) }\end{array}$ & - & $\begin{array}{l}\text { Produção; coleta } \\
\text { e } \\
\text { comercialização; } \\
\text { industrialização }\end{array}$ & $\begin{array}{l}\text { É um complexo industrial voltado para a produção e comercialização de farinha de trigo, arroz, e ração animal. A planta de } \\
\text { processamento de arroz é a maior do país. Além disso, conta com um laboratório para controle de qualidade dos produtos. O complexo } \\
\text { está localizado na colônia Fran, departamento de Itapúa, e foi fundado por migrantes ucranianos. É associada à CAPECO. }\end{array}$ \\
\hline
\end{tabular}

* Conforme apontado por Rojas (2009:51), algumas das empresas deste grupo, apesar de terem sido constituídas no país, são da propriedade (total ou parcial) de empresários estrangeiros, principalmente, de argentinos, brasileiros ou "brasiguaios". No quadro, o país de "vínculo" indica o país estrangeiro ao que essas empresas estariam vinculadas.

\section{LEGENDA}

(a) Notícia no Jornal ABC Color: http://www.abc.com.py/edicion-impresa/economia/empresa-aceitera-de-coronel-oviedo-realizo-una-inversion-de-us-1-millon-963828.html. Acesso em 24.04.2014

(b) http://www.agricolacolonial.com.py/

(c) Rojas (2009:60)

(d) http://www.capeco.org.py

(e) www.agrofertil.com.py; http://www.fiesp.com.br/noticias/empresarios-destacam-vantagens-competitivas-para-investimentos-no-paraguai/

(f) http://www.busanello.com.py/inicio

(g) Rojas (2009:60)

(h) http://www.agrihold.com/agrihold.com/index.html

(i) http://www.cappro.org.py

(J) http://www.ciabay.com/

(k) Notícia no Jornal ABC Color: http://www.abc.com.py/articulos/dueno-de-empresa-del-ano-2010-de-adec-cuenta-que-comenzo-de-cero-234318.html. Acesso em 24.04.2014

(L) http://www.diagro.com.py/

(m) http://www.ersa.com.py/

(n) http://www.grupofavero.com.py/home/

(o) http://www.frutika.com.py/

(p) http://inpasa.com.py/empresa

(p) Notícia no Jornal La Nación: http://www.lanacion.com.py/articulo/80552-inpasa-invirtio-us-55-millones-en-produccion-y-agroindustria-.html. Acesso em 24.04.2014

(p) Notícia no Jornal Última Hora: http://www.ultimahora.com/una-nueva-fabrica-alcohol-crea-300-puestos-trabajo-n138186.html. Acesso em: 24.04.2014 
(Q) http://www.mhp.com.py/

(R) http://www.oleaginosa.com/pagina.html

(s) http://www.capeco.org.py

(s) Notícia no Jornal ABC Color: http://www.abc.com.py/nacionales/tres-muertos-en-desmoronamiento-de-silo-1214065.html. Acesso em 24.04.2014

(t) Notícia no Jornal ABC Color: http://www.abc.com.py/edicion-impresa/suplementos/centinela/silos-y-puertos-privados-convierten-a-antequera-en-centro-de-inversiones-567893.html. Acesso em

$\underline{24.04 .2014}$

(u) http://www.tecnomyl.com.py/ES/

(v) http://www.trociuk.com.py/htm/empresa.htm

Fonte: Elaboração própria a partir de Rojas (2009:51-66); páginas web das empresas (ver Legenda); páginas web das associações de grêmio (CAPPRO e CAPECO); e publicações em jornais. 
Tabela 24 - Principais cooperativas de produção do Paraguai - 2013

\begin{tabular}{|c|c|}
\hline Nome da Cooperativa & Descrição geral da cooperativa \\
\hline $\begin{array}{l}\text { Cooperativa Agropecuaria } \\
\text { Pindó LTDA. (a) }\end{array}$ & $\begin{array}{l}\text { Cooperativa de produção agrícola fundada em 1981, com a participação de imigrantes brasileiros. Localizada no departamento de Alto Paraná. Dedica-se à produção e } \\
\text { processamento de soja, milho, trigo e canola. Também realiza exportação dos grãos. Atualmente, conta com mais de } 630 \text { sócios que, em conjunto, somam em torno de } \\
50 \text { mil hectares. Além da produção de grãos, conta com outras unidades: moinho de milho, produção de sementes, produção de ração animal, serviços de assistência } \\
\text { técnica, e um supermercado. É uma das cooperativas que forma parte da UNICOOP. É associada à CAPECO e à FECOPROD. }\end{array}$ \\
\hline $\begin{array}{l}\text { Cooperativa Chortitzer } \\
\text { Komitee LTDA. (b) }\end{array}$ & $\begin{array}{l}\text { Cooperativa fundada por imigrantes canadenses de origem europeia (mennonitas), em 1962, no distrito de "Loma Plata" (departamento de Boquerón). Conta com } \\
\text { aproximadamente } 4651 \text { sócios, aos quais presta serviços para a produção, processamento e comercialização de seus produtos. Sua principal atividade é a pecuária, e a } \\
\text { elaboração de produtos a partir dessa atividade, como lácteos, carnes e embutidos. Possui a maior participação no mercado lácteo do país (com a marca "Trébol"). É } \\
\text { proprietária da planta frigorífica "Frigochorti”, uma das maiores do país. Também contam com uma pequena produção agrícola (amendoim, algodão e sorgo). É uma } \\
\text { das cooperativas que forma parte da CENCOPROD. É associada à FECOPROD. }\end{array}$ \\
\hline $\begin{array}{l}\text { Cooperativa Colonias Unidas } \\
\text { AGROPEC IND. LTDA. (c) }\end{array}$ & $\begin{array}{l}\text { Cooperativa de produção fundada em 1953. Está localizada no distrito de Obligado, no departamento de Itapúa, e conta com aproximadamente } 4.000 \text { sócios. Realiza } \\
\text { atividades de apoio à produção dos sócios, como assistência técnica, fornecimento de insumos, coleta, processamento e comercialização dos produtos. O cultivo mais } \\
\text { importante é a soja. Também são produzidos: trigo, milho, girassol, sorgo, erva mate e canola. No setor industrial, produz e comercializa produtos como óleo e pellets } \\
\text { de soja. Também tem uma unidade de produção de leite e de ração animal. É uma das cooperativas que faz parte da UNICOOP. É associada à CAPECO e à } \\
\text { FECOPROD. }\end{array}$ \\
\hline $\begin{array}{l}\text { Cooperativa Colonizadora } \\
\text { Multiactiva Fernheim (d) }\end{array}$ & $\begin{array}{l}\text { Cooperativa de produção fundada em } 1930 \text { por colonos mennonitas, no distrito de "Filadelfia", na região do Chaco. A cooperativa se dedica, fundamentalmente, à } \\
\text { atividade pecuária, possuindo uma planta industrial (frigorífico) e um supermercado. Realiza atividades de apoio à produção de seus sócios, comercializando os } \\
\text { produtos no mercado nacional e internacional (é a cooperativa com maior exportação do país). Também possui produção agrícola (amendoim, sorgo, sésamo, algodão, } \\
\text { etc.). É uma das cooperativas que faz parte da CENCOPROD. É associada à FECOPROD. }\end{array}$ \\
\hline $\begin{array}{l}\text { Cooperativa de Producción } \\
\text { Agroindustrial Santa Maria } \\
\text { LTDA. (e) }\end{array}$ & $\begin{array}{l}\text { Cooperativa de produção fundada em 1991, com a participação de migrantes brasileiros. Está localizada no Alto Paraná. Realiza atividades de apoio à produção de } \\
\text { seus sócios, coletando e exportando soja, milho e trigo, principalmente. É uma das cooperativas que faz parte da UNICOOP. É sócia da CAPECO e da FECOPROD. }\end{array}$ \\
\hline $\begin{array}{l}\text { Cooperativa de Producción } \\
\text { Agropecuaria Naranjal } \\
\text { LTDA. - COPRONAR (f) } \\
\end{array}$ & $\begin{array}{l}\text { Cooperativa de produção fundada em 1991. Localiza-se no distrito de Naranjal, no Alto Paraná. Dedica-se à produção, coleta e comercialização de grãos. O principal } \\
\text { cultivo da cooperativa é a soja, que ocupa uma área de } 15 \text { mil hectares. Também são cultivados milho, trigo e canola. É uma das cooperativas que faz parte da } \\
\text { UNICOOP. É sócia da FECOPROD. }\end{array}$ \\
\hline $\begin{array}{l}\text { Cooperativa Multiactiva de } \\
\text { Producción Cons. Serv. } \\
\text { Cooperalba LTDA. (g) }\end{array}$ & $\begin{array}{l}\text { Cooperativa de produção agrícola fundada em } 2001 \text {, no distrito de "Caballero Álvarez", no departamento de Canindeyú. A atividade principal é o cultivo rotativo de } \\
\text { grãos: soja, milho, trigo, girassol, sorgo, etc. Realiza a exportação de seus produtos. Também conta com uma planta de produção de amido de milho. É uma das } \\
\text { cooperativas que faz parte da UNICOOP. É sócia da FECOPROD. }\end{array}$ \\
\hline
\end{tabular}


Cooperativa Multiactiva Neuland LTDA. (h)

\section{Cooperativa Volendam} LTDA. (i)

Cooperativa Agrícola

Friesland LTDA. (J)

\section{Cooperativa de Producción \\ de Leche la Holanda LTDA.} (k)

Cooperativa Yguazú Agrícola (L)

Cooperativa fundada em 1949 por imigrantes mennonitas na região do Chaco. A principal atividade da cooperativa é a pecuária, contanto também com plantas frigoríficas para a industrialização da carne. Também se destaca na elaboração de produtos lácteos. Conta também com produção agrícola (amendoim e sésamo). É uma das cooperativas que faz parte da CENCOPROD. É sócia da FECOPROD.

Cooperativa de produção fundada por migrantes mennonitas em 1947, no distrito de "Villa del Rosario", no departamento de San Pedro (na região oriental do país). Seus principais cultivos são soja, trigo e sorgo. Também se dedica à atividade pecuária (bovina e suína). É sócia da FECOPROD.

Cooperativa de produção fundada por migrantes mennonitas no distrito de "Itacurubí del Rosario", no departamento de San Pedro, em 1947. Dedica-se a atividade agrícola e pecuária. Possui uma fábrica de ração animal, e uma planta de produção de lácteos. Oferece serviços de coleta e comercialização de grãos (soja, milho, trigo, girassol, sorgo, etc.), gado e leite. A comercialização da carne é realizada em associação com a cooperativa Neuland. É sócia da FECOPROD.

Cooperativa iniciada em 1979, localizada no distrito de "J. Eulogio Estigarribia", no departamento de Caaguazú. É um referente nacional na produção e comercialização de produtos lácteos. É sócia da FECOPROD.

Cooperativa localizada no distrito de Yguazú, no departamento de Alto Paraná. Seu principal cultivo é a soja. É associada à CAPECO e à FECOPROD.

\section{União de cooperativas}

Central de Cooperativas de

Producción CENCOPROD LTDA. (m)

A central nasceu em 2007, a partir da aliança das três maiores cooperativas da região do Chaco, líderes na produção de carne e derivados: a Cooperativa Chortitzer, a Cooperativa Fernheim e a Cooperativa Neuland. O primeiro projeto comum foi a construção de uma planta processadora de couros bovinos, que iniciou suas atividades em 2009. Em 2013, inauguraram outra planta industrial, para o processamento de farinha de carne e ossos, e de gordura industrial. O complexo industrial está localizado na cidade de "Villa Hayes", na região do Chaco.

Fundada em 1995, conta atualmente com 8 cooperativas sócias, entre as quais: a Cooperativa Colonias Unidas, a COOPASAM, a COPRONAR, a Cooperativa Pindó, a COPERALBA - todas mencionadas acima (representam as principais produtoras de soja). Por meio da central, as cooperativas sócias canalizam seus esforços para a

Central Nacional de Cooperativas - UNICOOP (n) insumos e a venda de sua produção, a fim de conseguir melhores preços. Em conjunto, possuem uma superficie de aproximadamente 330 mil hectares, com uma importante produção de grãos: soja, trigo, milho, girassol e canola. O esforço de canalização é um primeiro objetivo da Central, que também pretende promover a instalação de unidades agroindustriais para a transformação dos cultivos produzidos pelos sócios, assim como a instalação de fábricas de processamento de insumos.

Federación de Cooperativas de Producción - FECOPROD Associação de grêmio criada em 1975, conta atualmente com 33 cooperativas associadas, congregando a 22.000 mil produtores, que representam $60 \%$ da produção
agropecuária do país. A federação tem como propósito principal o fortalecimento institucional, defendendo os interesses econômicos e sociais de suas associadas. Todas as cooperativas mencionadas fazem parte desta Federação.

\section{LEGENDA}

(a) http://www.pindo.com.py/

(b) http://www.chortitzer.com.py/ 
(c) www.colonias.com.py

(d) http://www.fernheim.com.py/

(e) http://www.coopasam.com/

(f) http://www.copronar.com.py/

(g) http://www.cooperalba.coop.py/

(h) http://www.neuland.com.py/

(i) http://www.fecoprod.com.py/index.php?option=com_content\&view=article\&id=143:cooperativa-volendam-ltda\&catid=52:cooperativa\&Itemid=61

(J) http://friesland.com.py/

(k) http://www.lactolanda.com.py/

(L) http://www.geocities.co.jp/HeartLand-Oak/4700/ESP00.html

(m) http://www.cencoprod.com.py/

(n) http://www.unicoop.com.py/

(o) http://www.fecoprod.com.py/

Fonte: Elaboração própria com base em ROJAS (2009:66-71); páginas web das cooperativas (ver Legenda); páginas web das associações de grêmio (CAPECO e FECOPROD); e publicações em jornais 
Tabela 25 - Importações totais das transnacionais atuantes no segmento de fornecimento de insumos no Paraguai (2009-2013)

\begin{tabular}{|c|c|c|c|c|c|}
\hline \multirow{2}{*}{ Empresa } & \multicolumn{5}{|c|}{ Importações Totais (US\$/FOB) } \\
\hline & 2013 & 2012 & 2011 & 2010 & 2009 \\
\hline ADM Paraguay & $80.753 .380,30$ & $103.393 .914,20$ & $128.712 .113,12$ & $73.478 .714,70$ & $53.864 .279,10$ \\
\hline $\begin{array}{l}\text { Bayer S. A. / Bayer } \\
\text { CropScience }\end{array}$ & $36.804 .977,80$ & $30.210 .073,00$ & $228.000,00$ & $29.453 .796,00$ & $19.852 .765,60$ \\
\hline Bunge Paraguay & $20.567 .378,70$ & $22.338 .446,10$ & $23.255 .664,74$ & $27.065 .110,60$ & $22.348 .789,30$ \\
\hline Cargill Agropecuaria & $28.286 .426,30$ & $22.604 .167,10$ & $24.342 .866,37$ & $23.573 .098,10$ & $24.696 .488,60$ \\
\hline CHS del Paraguay S.R.L & $5.170 .592,00$ & - & - & - & \\
\hline $\begin{array}{ll}\text { Dow } & \text { Agrosciences } \\
\text { Paraguay } & \\
\end{array}$ & $29.956 .935,60$ & $22.738 .793,80$ & $20.016 .053,75$ & $17.956 .859,50$ & $14.516 .325,90$ \\
\hline $\begin{array}{l}\text { Louis Dreyfus } \\
\text { Commodities (LDC) }\end{array}$ & - & - & $9.849 .010,79$ & $5.650 .378,00$ & - \\
\hline Mosanto Paraguay & $29.695 .120,20$ & $16.275 .679,80$ & $21.302 .433,82$ & $7.832 .873,80$ & $105.357,00$ \\
\hline Nidera Paraguay & $1.148 .597,10$ & - & - & - & - \\
\hline Noble Paraguay & $62.342 .220,10$ & $45.172 .915,90$ & $51.936 .499,09$ & $1.705 .043,00$ & $8.963 .960,60$ \\
\hline Syngenta Paraguay & $82.040 .786,30$ & $62.901 .774,20$ & - & - & - \\
\hline (A) TOTAL EMPRESAS & 376.766.414 & 325.635.764 & 279.642.642 & 186.715 .874 & 144.347 .966 \\
\hline (B) TOTAL PAÍS & 11.302.069.464 & 10.756.391.284 & 11.548.963.186 & 9.393.216.405 & 6.516.640.492 \\
\hline$\%(\mathrm{~A} / \mathrm{B})$ & $3,3 \%$ & $\mathbf{3 , 0 \%}$ & $2,4 \%$ & $2,0 \%$ & $2,2 \%$ \\
\hline
\end{tabular}

Fonte: Elaboração própria com base em dados do CIP (2014) e do BCP (2014a)

\section{Tabela 26 - Exportações totais das cinco maiores empresas do grupo "Outras firmas estrangeiras do agronegócio" (2009-2013)}

\begin{tabular}{|c|c|c|c|c|c|}
\hline \multirow{2}{*}{ Empresa } & \multicolumn{5}{|c|}{ Exportações Totais (US\$/FOB) } \\
\hline & 2013 & 2012 & 2011 & 2010 & 2009 \\
\hline $\begin{array}{l}\text { Compañía Paraguaya de } \\
\text { Granos (COPAGRA) }\end{array}$ & $66.646 .701,10$ & - & - & - & - \\
\hline $\begin{array}{l}\text { Desarrollo Agrícola del } \\
\text { Paraguay S.A (DAP) }\end{array}$ & $23.115 .242,60$ & $23.682 .787,80$ & $34.008 .904,64$ & 27.922.532,90 & - \\
\hline Grupo Minerva & $202.997 .767,80$ & $171.851 .231,40$ & $181.144 .748,42$ & $202.956 .160,70$ & $158.638 .968,80$ \\
\hline FRIASA & $83.091 .793,30$ & $74.319 .075,80$ & $66.725 .869,39$ & $75.383 .022,20$ & $58.853 .574,30$ \\
\hline FrigoMERC & $119.905 .974,50$ & $97.532 .155,60$ & $114.418 .879,03$ & $127.573 .138,50$ & $99.785 .394,50$ \\
\hline LAR S.R.L. & $25.400 .911,90$ & $34.217 .690,00$ & 26.666.440,00 & $17.971 .190,00$ & $18.229 .370,00$ \\
\hline VICENTIN PARAGUAY & $152.932 .233,60$ & $56.873 .994,10$ & $131.251 .230,07$ & $100.904 .221,90$ & $49.822 .234,30$ \\
\hline (A) TOTAL EMPRESAS & 471.092.857,00 & 286.625.703,30 & 373.071.323,13 & 349.754.105,50 & 226.690.573,10 \\
\hline (B) TOTAL PAÍS & 9.432 .340 .950 & 7.283.873.876 & 7.776.434.535 & 6.516 .557 .119 & 5.079 .610 .902 \\
\hline$\%(\mathrm{~A} / \mathrm{B})$ & $5,0 \%$ & $3,9 \%$ & $4,8 \%$ & $5,4 \%$ & $4,5 \%$ \\
\hline
\end{tabular}

Fonte: Elaboração própria com base em dados do CIP (2014) e do BCP (2014a) 
Tabela 27 - Exportações e importações das empresas "brasiguaias" (20092013)

\begin{tabular}{|c|c|c|c|c|c|}
\hline \multirow{2}{*}{ Empresas } & \multicolumn{5}{|c|}{ Exportações totais (US\$/FOB) } \\
\hline & 2013 & 2012 & 2011 & 2010 & 2009 \\
\hline Agrofértil S.A. & $81.034 .379,20$ & 79.977.620,20 & $77.056 .397,64$ & $48.781 .825,20$ & 19.257.253,50 \\
\hline Agrotec S.A. & 21.282.309,90 & $12.028 .782,00$ & $20.536 .945,35$ & $17.598 .344,10$ & $8.946 .401,30$ \\
\hline Grupo Favero & $163.373 .484,10$ & $129.442 .008,10$ & 178.020.497,41 & $87.165 .794,10$ & $48.236 .932,30$ \\
\hline $\begin{array}{l}\text { Agro Silo Santa Catalina } \\
\text { S.A. }\end{array}$ & $149.757 .753,40$ & $119.403 .704,90$ & $167.485 .743,42$ & $83.094 .176,50$ & $44.834 .897,40$ \\
\hline Agrotoro S.A. & $13.615 .730,70$ & $10.038 .303,20$ & $10.534 .753,99$ & $4.071 .617,60$ & $3.402 .034,90$ \\
\hline Aktra S.A. & - & - & - & - & - \\
\hline Ganadera Campo Bello & - & - & - & - & - \\
\hline $\begin{array}{lll}\text { Ganadera Forestal Santa } \\
\text { Catalina }\end{array}$ & - & - & - & - & - \\
\hline $\begin{array}{lll}\text { Agro } \\
\text { Liberato }\end{array}$ & - & - & - & - & - \\
\hline Semillas Verónica & - & - & - & - & - \\
\hline Totem S.A. & - & - & - & - & - \\
\hline Trafa S.A. & - & - & - & - & - \\
\hline Tecnomyl S.A. & $15.665 .961,80$ & $14.771 .464,60$ & $9.849 .394,37$ & $5.995 .443,60$ & $7.573 .375,00$ \\
\hline (A) TOTAL EMPRESAS & 281.356.135,00 & 236.219.874,90 & 285.463.234,77 & 159.541.407,00 & 84.013.962,10 \\
\hline (B) TOTAL PAÍS & 9.432 .340 .950 & 7.283.873.876 & 7.776.434.535 & 6.516.557.119 & 5.079.610.902 \\
\hline$\%(\mathbf{A} / \mathbf{B})$ & $3,0 \%$ & $3,2 \%$ & $3,7 \%$ & $2,4 \%$ & $1,7 \%$ \\
\hline
\end{tabular}

\begin{tabular}{|c|c|c|c|c|c|}
\hline \multirow{2}{*}{ Empresas "brasiguaias" } & \multicolumn{5}{|c|}{ Importações totais US\$/FOB } \\
\hline & 2013 & 2012 & 2011 & 2010 & 2009 \\
\hline Agrofértil S.A. & $89.043 .537,20$ & $73.107 .375,30$ & $91.369 .954,92$ & $74.449 .860,60$ & $64.876 .299,10$ \\
\hline Agrotec S.A. & $96.947 .930,30$ & $74.705 .528,40$ & $90.960 .060,54$ & $53.571 .132,20$ & $56.126 .600,40$ \\
\hline Grupo Favero & $31.382 .953,70$ & $24.142 .611,00$ & $29.415 .720,96$ & $20.470 .973,60$ & $14.807 .381,00$ \\
\hline $\begin{array}{l}\text { Agro Silo Santa Catalina } \\
\text { S.A. }\end{array}$ & $18.151 .298,50$ & $10.677 .807,80$ & $15.880 .181,72$ & $12.607 .775,40$ & $5.726 .977,90$ \\
\hline Agrotoro S.A. & - & $397.800,00$ & - & $272.532,40$ & - \\
\hline Aktra S.A. & $13.231 .655,20$ & $13.067 .003,20$ & $13.535 .539,24$ & $7.590 .665,80$ & $9.080 .403,10$ \\
\hline Ganadera Campo Bello & - & - & - & - & - \\
\hline $\begin{array}{l}\text { Ganadera Forestal Santa } \\
\text { Catalina }\end{array}$ & - & - & - & - & - \\
\hline $\begin{array}{lll}\begin{array}{l}\text { Agro Ganadera } \\
\text { Liberato }\end{array} & \text { San } \\
\end{array}$ & - & - & - & - & - \\
\hline Semillas Verónica & - & - & - & - & - \\
\hline Totem S.A. & - & - & - & - & - \\
\hline Trafa S.A. & - & - & - & - & - \\
\hline Tecnomyl S.A. & $77.561 .026,10$ & $53.644 .520,30$ & $46.420 .000,09$ & 47.527.018,70 & $28.495 .351,40$ \\
\hline (A) TOTAL EMPRESAS & 294.935.447,30 & $225.600 .035,00$ & 258.165.736,51 & 196.018.985,10 & 164.305.631,90 \\
\hline (B) TOTAL PAÍS & 11.302.069.464 & 10.756.391.284 & 11.548.963.186 & 9.393.216.405 & 6.516.640.492 \\
\hline$\%(\mathrm{~A} / \mathrm{B})$ & $2,6 \%$ & $2,1 \%$ & $2,2 \%$ & $2,1 \%$ & $2,5 \%$ \\
\hline
\end{tabular}

Fonte: Elaboração própria com base em dados do CIP (2014) e do BCP (2014a) 
Tabela 28 - Importações totais das empresas locais do agronegócio (20092013)

\begin{tabular}{|c|c|c|c|c|c|}
\hline \multirow{2}{*}{ Empresa } & \multicolumn{5}{|c|}{ Importações totais (US\$/FOB) } \\
\hline & 2013 & 2012 & 2011 & 2010 & 2009 \\
\hline Agrícola Colonial S.A.I.C. & $7.549 .568,40$ & $569.900,00$ & $66.800,00$ & - & \\
\hline Agro Santa Rosa S.A.E. & $137.053,50$ & $54.534,90$ & $58.396,44$ & $23.443,30$ & $23.443,30$ \\
\hline Agrofértil S.A. & $89.043 .537,20$ & $73.107 .375,30$ & $91.369 .954,92$ & $74.449 .860,60$ & $64.876 .299,10$ \\
\hline Agroser S.A. & $26.577,30$ & $153.553,50$ & - & - & $1.474 .646,00$ \\
\hline Agrotec S.A. & $96.947 .930,30$ & $74.705 .528,40$ & $90.960 .060,54$ & $53.571 .132,20$ & $56.126 .600,40$ \\
\hline $\begin{array}{lll}\text { Comercial } & \text { e } & \text { Industrial } \\
\text { Amambay } & \text { - CIABAY } & \text { S.A. }\end{array}$ & $93.813 .338,60$ & $49.757 .876,00$ & $111.988 .402,64$ & $66.659 .003,00$ & $28.047 .778,00$ \\
\hline Dekalpar S.A. & $34.459 .010,30$ & $41.245 .363,90$ & $34.900 .386,47$ & $24.159 .072,70$ & $17.397 .246,90$ \\
\hline Diagro S.A. & $15.842 .556,90$ & $17.286 .468,50$ & $12.717 .982,64$ & $29.593 .690,00$ & $20.469 .994,90$ \\
\hline $\begin{array}{l}\text { Agro Silo Santa Catalina S.A. - } \\
\text { Grupo Favero * }\end{array}$ & $18.151 .298,50$ & $10.677 .807,80$ & $15.880 .181,72$ & $12.607 .775,40$ & $5.726 .977,90$ \\
\hline Agrotoro S.A. - Grupo Favero & - & $397.800,00$ & - & $272.532,40$ & - \\
\hline Aktra S.A. - Grupo Favero & $13.231 .655,20$ & $13.067 .003,20$ & $13.535 .539,24$ & $7.590 .665,80$ & $9.080 .403,10$ \\
\hline Tecnomyl S.A. & $77.561 .026,10$ & $53.644 .520,30$ & $46.420 .000,09$ & $47.527 .018,70$ & $28.495 .351,40$ \\
\hline (A) TOTAL EMPRESAS & 446.763.552 & 334.667 .732 & 417.897.705 & 316.454.194 & 231.718.741 \\
\hline (B) TOTAL PAÍS & 11.302.069.464 & 10.756.391.284 & 11.548.963.186 & 9.393.216.405 & 6.516.640.492 \\
\hline$\%(\mathrm{~A} / \mathrm{B})$ & $4,0 \%$ & $3,1 \%$ & $3,6 \%$ & $3,4 \%$ & $3,6 \%$ \\
\hline \multicolumn{6}{|c|}{$\begin{array}{l}\text { Obs.: A empresa Kimex S.R.L. - do Grupo Kress - que também é classificada como fornecedora de insumos (ver Tabela } \\
\text { 23) não foi incluída neste quadro, uma vez que registra valores de importação irrisórios, significando que a importação não } \\
\text { faz parte da atividade foco do Grupo, como é o caso das empresas apresentadas. } \\
\text { *Nos registros do CIP (2014) não foram encontrados os montantes de comércio exterior para as empresas "Semillas } \\
\text { Verónica" e "Trafa S.A." do Grupo Favero, que também realizam atividades de fornecimento de insumos (via importação } \\
\text { e comercialização no mercado local). Porém, trata-se de duas empresas que são divisões da firma "Agro Silo Santa } \\
\text { Catalina" (do mesmo Grupo), significando que devem realizar suas operações de importação por meio desta última. Por } \\
\text { esse motivo, não foram listadas de forma separada neste quadro. }\end{array}$} \\
\hline
\end{tabular}

Fonte: Elaboração própria com base em dados do CIP (2014) e do BCP (2014a) 
Tabela 29 - Exportações totais das empresas locais do agronegócio (20092013)

\begin{tabular}{|c|c|c|c|c|c|}
\hline \multirow{2}{*}{ Empresa } & \multicolumn{5}{|c|}{ Exportações totais (US\$/FOB) } \\
\hline & 2013 & 2012 & 2011 & 2010 & 2009 \\
\hline Aceites y Derivados S.A. (ADESA) & $15.790 .473,60$ & $9.125 .119,00$ & $11.722 .347,00$ & $16.628 .119,00$ & $15.790 .099,20$ \\
\hline Agrícola Colonial S.A.I.C. & $12.218 .152,00$ & $15.938 .616,00$ & $914.920,00$ & - & \\
\hline Agro Santa Rosa S.A.E. & $771.700,00$ & $1.546 .375,00$ & $2.162 .000,00$ & $955.500,00$ & $3.187 .000,00$ \\
\hline Agro Silos El Productor & $10.528 .141,90$ & $14.677 .163,00$ & $10.806 .095,00$ & $6.377 .590,00$ & $7.525 .750,00$ \\
\hline Agrofértil S.A. & $81.034 .379,20$ & 79.977.620,20 & $77.056 .397,64$ & $48.781 .825,20$ & $19.257 .253,50$ \\
\hline Agropecuaria Busanello S.A. & - & - & $2.023 .000,00$ & $9.136 .766,30$ & $230.000,00$ \\
\hline Agroser S.A. & $6.387 .000,00$ & $4.805 .400,00$ & $3.456 .950,00$ & $3.529 .500,00$ & $5.264 .676,80$ \\
\hline Agrotec S.A. & 21.282.309,90 & $12.028 .782,00$ & $20.536 .945,35$ & $17.598 .344,10$ & $8.946 .401,30$ \\
\hline $\begin{array}{l}\text { Alberto Giles Agroexportadora } \\
\text { (ALGISA) }\end{array}$ & $3.706 .465,70$ & $2.866 .445,30$ & $3.614 .628,90$ & $187.583,60$ & - \\
\hline Diagro S.A. & $8.683 .100,00$ & $7.832 .100,00$ & $9.196 .200,00$ & $10.073 .290,00$ & $5.890 .636,00$ \\
\hline Enrique Remmele S.A.C.I (ERSA) & $193.766,80$ & - & - & & $19.600,00$ \\
\hline $\begin{array}{c}\text { Agro Silo Santa Catalina S.A. - } \\
\text { Grupo Favero }\end{array}$ & $149.757 .753,40$ & $119.403 .704,90$ & $167.485 .743,42$ & $83.094 .176,50$ & $44.834 .897,40$ \\
\hline Agrotoro S.A. - Grupo Favero & $13.615 .730,70$ & $10.038 .303,20$ & $10.534 .753,99$ & $4.071 .617,60$ & $3.402 .034,90$ \\
\hline $\begin{array}{c}\text { Estancia Beate Verónica Holtker - } \\
\text { Grupo Kress }\end{array}$ & $11.991 .552,80$ & $10.862 .427,10$ & $11.698 .618,24$ & $6.541 .393,40$ & $8.667 .219,20$ \\
\hline $\begin{array}{c}\text { Industria Paraguaya de Alcoholes } \\
\text { S.A. (INPASA) } \\
\end{array}$ & $13.813 .325,00$ & $16.126 .406,20$ & $9.929 .429,00$ & $435.090,00$ & $598.350,00$ \\
\hline Oleaginosa RAATZ S.A. & $49.100 .880,90$ & $43.538 .624,10$ & 46.967.929,66 & $27.260 .316,60$ & $10.532 .869,70$ \\
\hline Ovetril S.A. & $5.219 .500,00$ & $6.586 .598,00$ & $8.727 .600,00$ & $1.946 .020,00$ & $1.807 .500,00$ \\
\hline Salto Aguaray S.R.L & $78.483 .330,60$ & $73.216 .259,70$ & $74.792 .918,65$ & $53.930 .808,80$ & $36.808 .434,50$ \\
\hline $\begin{array}{c}\text { TROCIUK \& Compañia Agrícola } \\
\text { Ganadera Industrial S.A. }\end{array}$ & $22.034 .563,00$ & $12.200 .993,30$ & $14.955 .167,53$ & $9.136 .766,30$ & $3.234 .500,50$ \\
\hline (A) TOTAL EMPRESAS & 504.612 .126 & 440.770.937 & 486.581.644 & 299.684.707 & 175.997.223 \\
\hline (B) TOTAL PAÍS & 9.432.340.950 & 7.283.873.876 & 7.776.434.535 & 6.516.557.119 & 5.079 .610 .902 \\
\hline$\%(\mathrm{~A} / \mathrm{B})$ & $5,3 \%$ & $6,1 \%$ & $6,3 \%$ & $4,6 \%$ & $3,5 \%$ \\
\hline
\end{tabular}

Fonte: Elaboração própria com base em dados do CIP (2014) e do BCP (2014a) 
Tabela 30 - Exportações totais das cooperativas de produção do Paraguai (2009-2013)

\begin{tabular}{|c|c|c|c|c|c|}
\hline \multirow[b]{2}{*}{ Cooperativa } & \multicolumn{5}{|c|}{ Exportações totais (US\$/FOB) } \\
\hline & 2013 & 2012 & 2011 & 2010 & 2009 \\
\hline Agropecuaria Pindo LTDA. & $12.694 .333,40$ & $24.952 .356,30$ & $5.674 .692,00$ & $17.195 .180,10$ & $9.781 .854,00$ \\
\hline Chortizer Komitee LTDA. & $91.111 .914,90$ & $64.592 .243,00$ & $86.244 .196,25$ & $100.494 .848,20$ & $66.334 .337,20$ \\
\hline $\begin{array}{l}\text { Colonias Unidas AGROPEC IND. } \\
\text { LTDA. }\end{array}$ & $47.754 .433,50$ & $37.602 .452,70$ & $16.361 .583,23$ & $44.175 .612,90$ & $44.747 .180,70$ \\
\hline \begin{tabular}{ll|} 
Colonizadora & Multiactiva \\
Fernheim & \\
\end{tabular} & $118.267 .202,30$ & $119.031 .745,00$ & $88.264 .114,58$ & $114.014 .855,30$ & $66.385 .029,50$ \\
\hline 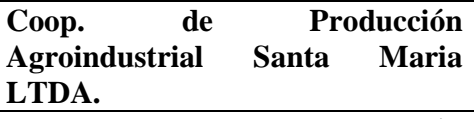 & $1.832 .500,00$ & $12.625 .500,00$ & $7.212 .000,00$ & $4.072 .175,00$ & $5.996 .100,00$ \\
\hline $\begin{array}{l}\text { Coop. de Producción } \\
\text { Agropecuaria Naranjal LTDA. - } \\
\text { COPRONAR }\end{array}$ & $13.301 .524,10$ & $18.063 .186,00$ & $8.170 .564,00$ & $7.833 .520,00$ & $1.657 .877,00$ \\
\hline $\begin{array}{l}\text { Coop. Multiactiva de Producción } \\
\text { Cons. Serv. Cooperalba LTDA. }\end{array}$ & $3.208 .932,40$ & $4.012 .513,90$ & $6.034 .250,00$ & $5.858 .820,00$ & $9.989 .400,00$ \\
\hline $\begin{array}{lll}\text { Coop. } & \text { Multiactiva } & \text { Neuland } \\
\text { LTDA. } & & \\
\end{array}$ & $30.153 .024,60$ & $20.413 .377,30$ & $34.895 .571,69$ & $41.954 .345,30$ & $20.583 .037,90$ \\
\hline Volendam LTDA. & $11.961 .375,80$ & 20.413.377,30 & 24.154.650,91 & $11.475 .709,20$ & $8.558 .607,10$ \\
\hline Agrícola Friesland LTDA. & - & - & - & - & $878.527,90$ \\
\hline $\begin{array}{l}\text { Coop. de Producción de Leche la } \\
\text { Holanda LTDA. }\end{array}$ & $7.984 .500,00$ & $225.500,00$ & - & - & - \\
\hline Yguazú Agrícola & $755.712,00$ & $228.366,00$ & $2.032 .167,00$ & $1.245 .184,50$ & $536.853,00$ \\
\hline $\begin{array}{l}\text { Central de } \begin{array}{c}\text { Cooperativas de } \\
\text { CENCOPROD } \\
\text { Producción }\end{array} \\
\text { LTDA. (Coop. Chortizer + Coop. } \\
\text { Fernheim + Coop. Neuland) }\end{array}$ & $15.677 .954,70$ & $13.436 .962,60$ & $17.195 .180,10$ & $23.441 .745,40$ & $5.100 .664,10$ \\
\hline (A) TOTAL COOPERATIVAS & 354.703.408 & 335.597.580 & 296.238.970 & 371.761 .996 & 240.549.468 \\
\hline (B) TOTAL PAÍS & 9.432 .340 .950 & 7.283.873.876 & 7.776.434.535 & 6.516.557.119 & 5.079 .610 .902 \\
\hline$\%(\mathrm{~A} / \mathrm{B})$ & $3,8 \%$ & $4,6 \%$ & $3,8 \%$ & $5,7 \%$ & $4,7 \%$ \\
\hline
\end{tabular}

Fonte: Elaboração própria com base em dados do CIP (2014) e do BCP (2014a) 